
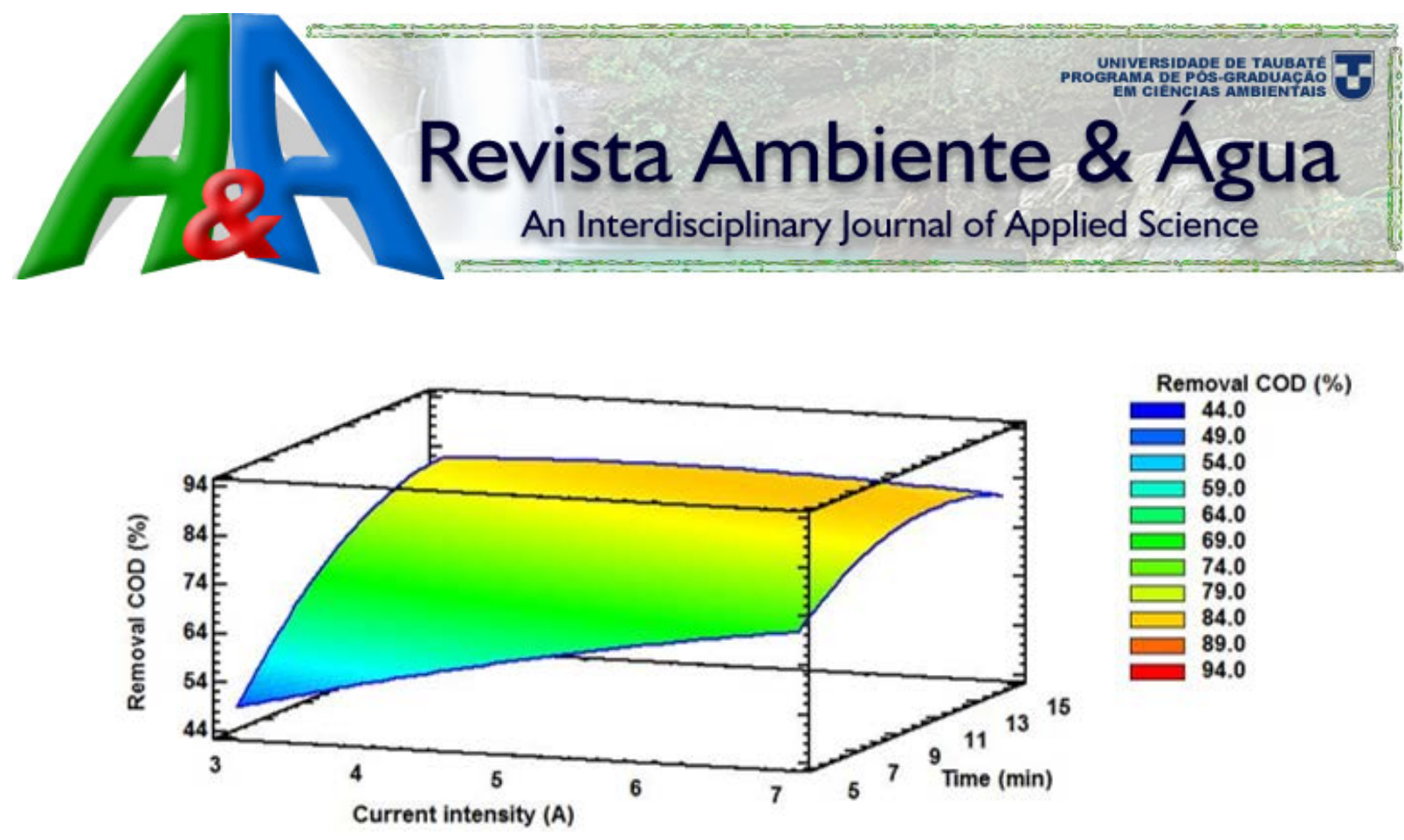

(9a)
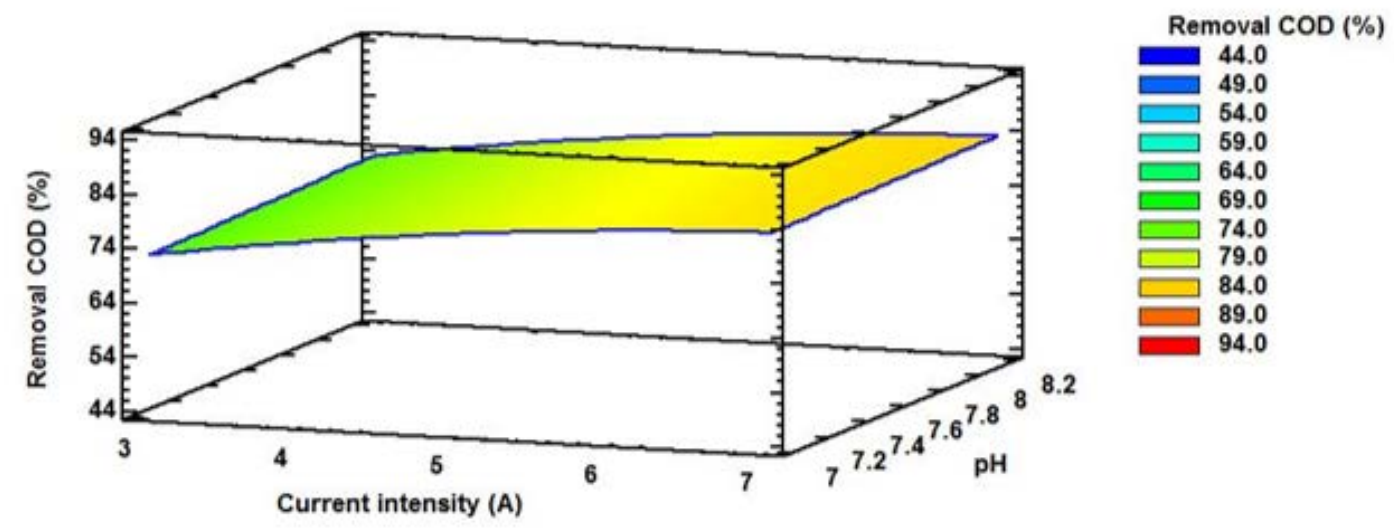

(9b)
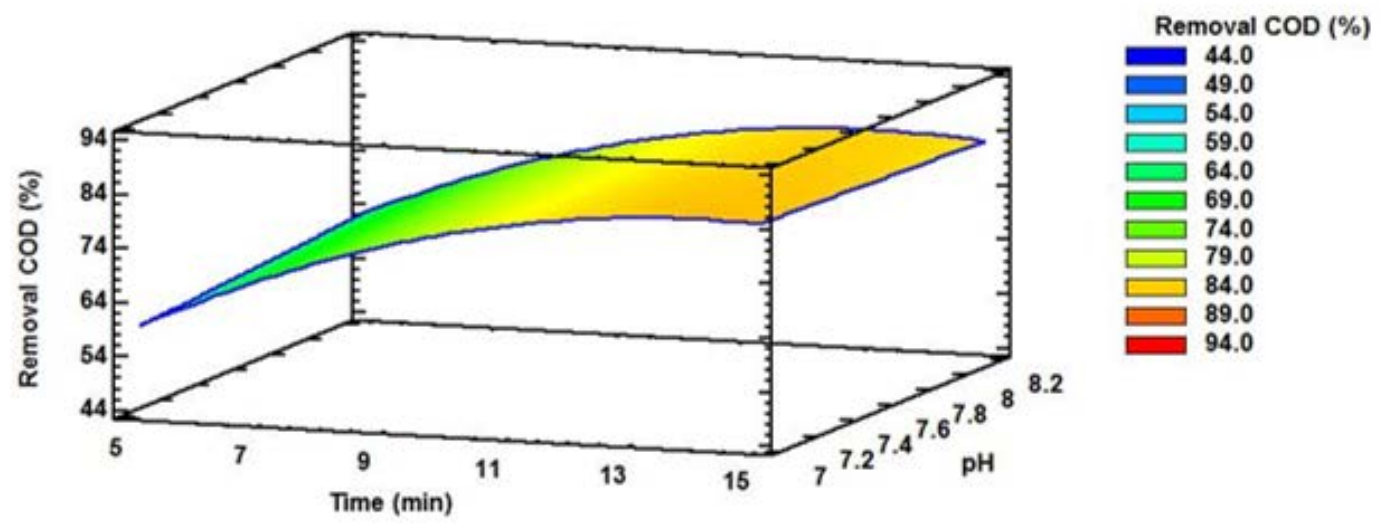

(9c) 


\section{EDITORIAL BOARD}

\section{Editors}

Getulio Teixeira Batista (Emeritus Editor) Universidade de Taubaté - UNITAU, BR

Nelson Wellausen Dias (Editor-in-Chief), Fundação Instituto Brasileiro de Geografia e Estatística - IBGE, BR

Ana Aparecida da Silva Almeida

Marcelo dos Santos Targa

Andrea Giuseppe Capodaglio

Arianna Callegari

Antonio Teixeira de Matos

Apostol Tiberiu

Claudia M. dos S. Cordovil

Dar Roberts

Giordano Urbini

Gustaf Olsson

Hélio Nobile Diniz

Ignacio Morell Evangelista

János Fehér

Julio Cesar Pascale Palhares

Luis Antonio Merino

Maria Cristina Collivignarelli

Massimo Raboni

Petr Hlavínek

Richarde Marques da Silva

Stefan Stanko

Teresa Maria Reyna

Yosio Edemir Shimabukuro

Zhongliang Liu Beijing

Text Editor

Reference Editor

Peer-Reviewing Process

System Analyst

Secretary and Communication

\section{Associate Editors}

Universidade de Taubaté (UNITAU), BR

Universidade de Taubaté (UNITAU), BR

\section{Editorial Commission}

University of Pavia, ITALY

Università degli Studi di Pavia, ITALY

Universidade Federal de Viçosa (UFV), BR

University Politechnica of Bucharest, Romênia

Centro de estudos de Engenharia Rural (CEER), Lisboa, Portugal

University of California, Santa Barbara, United States

University of Insubria, Varese, Italy

Lund University, Lund, Sweden

Inst. Geológico, Sec. do Meio Amb. do Est. de SP (IG/SMA), BR

University Jaume I- Pesticides and Water Research Institute, Spain

Debrecen University, Hungary

Embrapa Pecuária Sudeste, CPPSE, São Carlos, SP, BR

Institute of Regional Medicine, National University of the Northeast,

Corrientes, Argentina

University of Pavia, Depart. of Civil Engineering and Architecture, Italy

LIUC - University "Cattaneo", School of Industrial Engineering, Italy

Brno University of Technology República Tcheca

Universidade Federal da Paraíba (UFPB), BR

Slovak Technical University in Bratislava Slovak, Eslováquia

Universidad Nacional de Córdoba, Argentina

Instituto Nacional de Pesquisas Espaciais (INPE), BR

University of Technology, China

Theodore D`Alessio, FL, USA, Maria Cristina Bean, FL, USA

Liliane Castro, Bibliotecária - CRB/8-6748, Taubaté, BR

Marcelo Siqueira Targa, UNITAU, BR

Tiago dos Santos Agostinho, UNITAU, BR

Luciana Gomes de Oliveira, UNITAU, BR

\section{Library catalog entry by Liliane Castro CRB/8-6748}

Revista Ambiente \& Água - An Interdisciplinary Journal of Applied Science / Instituto de Pesquisas Ambientais em Bacias Hidrográficas. Taubaté. v. 13, n.5 (2006) - Taubaté: IPABHi, 2018.

Quadrimestral (2006 - 2013), Trimestral (2014 - 2016), Bimestral (2017), Publicação Contínua a partir de Janeiro de 2018.

Resumo em português e inglês.

ISSN 1980-993X

1. Ciências ambientais. 2. Recursos hídricos. I. Instituto de Pesquisas Ambientais em Bacias Hidrográficas.

CDD - 333.705

CDU - (03)556.18 


\section{TABLE OF CONTENTS}

\section{COVER:}

Domestic wastewater COD (Chemical Oxygen Demand) elimination using electrocoagulation is influenced by changes in current intensity, $\mathrm{pH}$ conditions and time. A three-dimension graphic visualization of the combination of two of these factors at a time is presented in this figure. Authors claim that this technique is more effective than biological processes for the removal of COD from domestic wastewater.

Source: ASCÓN, E. A. A. Elimination of chemical oxygen demand from domestic residual water by electrocoagulation with aluminum and iron electrodes.

Rev. Ambient. Água, Taubaté, vol. 13 n. 5, p. 1-16, 2018. doi:10.4136/ambi-agua.2240

\section{ARTICLES}

Photosynthetic efficiency and production of cowpea cultivars under deficit irrigation

01 doi:10.4136/ambi-agua.2133

Alberto Soares de Melo; Allisson Rafael Ferreira da Silva; Alexson Filgueiras Dutra;

Wellison Filgueiras Dutra; Marcos Eric Barbosa Brito; Francisco Vanies da Silva Sá

Use of statistical multivariate analysis to identify sources emitting particulate matter in Belo Horizonte, Brazil

02 doi:10.4136/ambi-agua.2202

Igor Felipe Silva Moura; Alberto Avellar Barreto; Raisa Helena Sant'Ana Cesar; Ananda Borjaille Cruz; Maria Ângela de Barros Correia Menezes

\section{Metrological performance of single-jet water meters over time}

03 doi:10.4136/ambi-agua.2205

Carmen Virginia Palau; Juan Manzano; Iban Balbastre Peralta; Benito Moreira de Azevedo;

Guilherme Vieira do Bomfim

Optimization of nitrogen and phosphorus removal from pig slaughterhouse and packing plant wastewater through electrocoagulation in a batch reactor

04 doi:10.4136/ambi-agua.2233

Fábio Orssatto; Maria Hermínia Ferreira Tavares; Flávia Manente da Silva; Eduardo Eyng; Leandro Fleck

\section{Estimation of corrosive and scaling trend in drinking water systems in the city of Azogues,} Ecuador

Fernando García-Ávila; Lía Ramos-Fernández; César Zhindón-Arévalo

Daily water demand

06 doi:10.4136/ambi-agua.2239

Francesco Lombardi; Guglielmo Silvagni; Sirini; Riccardo Spagnuolo; Fabio Volpi

Future scenarios of thermal bioclimatic conditions in a humid tropical city under urban development

07 doi:10.4136/ambi-agua.2092

Vicente de Paulo Rodrigues da Silva; Joel Silva Santos; Eduardo Rodrigues Viana de Lima;

Romildo Morant de Holanda; Enio Pereira de Sousa; Lincoln Eloi de Araújo

Cost of charging for water use in the Brazilian Cerrado hydrographic basin 
Elimination of chemical oxygen demand from domestic residual water by electrocoagulation with aluminum and iron electrodes

09

doi:10.4136/ambi-agua.2240

Edwar Alejandro Aguilar Ascón

Integration of treatment technologies with Fenton reagent for laboratory effluent remediation

10 doi:10.4136/ambi-agua.2243

Chrystopher Allan Miranda Pereira; Núbia Natália Brito

Incêndios no Pantanal de Corumbá, MS: modelagem e previsão a partir das técnicas de análise multivariada

11 doi:10.4136/ambi-agua.2024

Hevelyne Henn da Gama Viganó; Celso Correia de Souza; Marcia Ferreira Cristaldo;

José Francisco dos Reis Neto; Leandro de Jesus

Dinâmica temporal da pegada hídrica por cultivar de soja em polo de grãos no Oeste do Pará, Amazônia

12 doi:10.4136/ambi-agua.2051

Douglas Cavalcante Costa; Lucieta Guerreiro Martorano; José Reinaldo da Silva Cabral de Moraes; Leila Sheila Silva Lisboa; Rubismar Stolf 


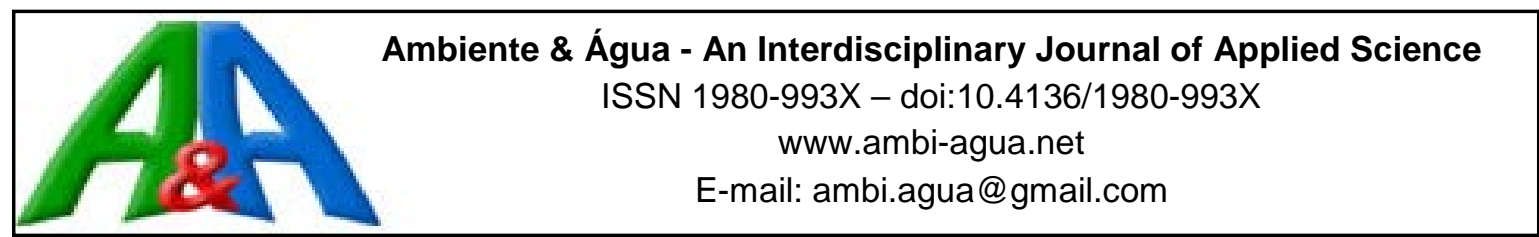

\title{
Photosynthetic efficiency and production of cowpea cultivars under deficit irrigation
}

\author{
ARTICLES doi:10.4136/ambi-agua.2133
}

Received: 15 May 2017; Accepted: 20 Aug. 2018

\begin{abstract}
Alberto Soares de Melo ${ }^{{ }^{*}}$; Allisson Rafael Ferreira da Silva ${ }^{1}$;
Alexson Filgueiras Dutra ${ }^{2}$; Wellison Filgueiras Dutra ${ }^{3}$; Marcos Eric Barbosa Brito ${ }^{4}$; Francisco Vanies da Silva Sá ${ }^{5}$
\end{abstract}

\author{
${ }^{1}$ Universidade Estadual da Paraíba (UEPB), Campina Grande, PB, Brasil \\ Departamento de Ciências Biológicas (DepBio). E-mail: alberto@uepb.edu.br, \\ engallisson.rafael@hotmail.com \\ ${ }^{2}$ Universidade Estadual Paulista "Júlio de Mesquita Filho" (UNESP), Jaboticabal, SP, Brasil \\ Departamento de Ciências Vegetais. E-mail: alexsondutra@gmail.com \\ ${ }^{3}$ Universidade Federal da Paraíba (UFPB), Areia, PB, Brasil \\ Departamento de Ciências Vegetais. E-mail: wellison_eu@hotmail.com \\ ${ }^{4}$ Universidade Federal de Sergipe (UFS), Nossa Senhora da Glória, SE, Brasil \\ Departamento de Engenharia Agronômica (DEA). E-mail: marcoseric@ufs.br \\ ${ }^{5}$ Universidade Federal Rural do Semi-Árido (UFERSA), Mossoró, RN, Brasil \\ Centro de Ciências Agrárias (CCA).E-mail: vanies_agronomia@hotmail.com \\ ${ }^{*}$ Corresponding author
}

\begin{abstract}
Cowpea is a crop with great economic, social and food importance in semi-arid regions, but its production is drastically reduced by the water deficit in these regions, requiring better management strategies that allow the crop's production. This study therefore aimed to evaluate the photosynthetic efficiency and production of cowpea cultivars under deficit irrigation replacement levels. The experiment tested three cowpea genotypes (G1 = 'BRS Aracé', G2 = 'BR 17 Gurguéia' and G3 = 'BRS Marataoã') and four irrigation depths (40, 60, 80 and $100 \%$ of ETc), resulting in a $3 \times 4$ factorial scheme, arranged in randomized complete blocks design with four replicates. During the experiment, the gas exchanges, chlorophyll a fluorescence and production of the cowpea genotypes under deficit irrigation were evaluated. Carbon fixation in the photosynthetic metabolism of cowpea plants was reduced by accentuated water deficit, regardless of the genotype. The low stress severity was indicated by the lack of effects on chlorophyll fluorescence, indicating that the reduction in the rate of carbon assimilation was due to the stomatal effects. The irrigation with $80 \%$ of ETc can be used in the cultivation of the respective cultivars, but with small losses in the production. Among the genotypes, 'BRS Marataoã' stands out with respect to yield, with higher values for weight of pods and green beans.
\end{abstract}

Keywords: gas exchanges, physiology, Vigna unguiculata, water replacement. 


\section{Eficiência fotossintética e produção de cultivares de feijão-caupi sob irrigação deficitária}

\section{RESUMO}

O feijão-caupi é uma cultura que apresenta grande importância econômica e sócioalimentar em regiões semiáridas, no entanto, sua produção é drasticamente reduzida pelo déficit hídrico ocorrente nessas regiões, sendo necessário traçar melhores estratégias de manejo que viabilizem a produção da cultura. Com isso, objetivou-se avaliar a eficiência fotossintética e a produção de genótipos de feijão-caupi sob níveis de reposição da irrigação deficitária. $\mathrm{O}$ experimento foi constituído por um estudo de três genótipos de feijão-caupi (G1 = BRS Aracé, G2 = BR 17 Gurgueia e G3 = BRS Marataoã) e quatro lâminas de irrigação (40, 60, 80 e 100\% da ETc), que aos combinados resulta em um fatorial 3 x 4, organizado no delineamento em blocos casualizados com quatro repetições. Durante a condução do experimento foram avaliadas as trocas gasosas, fluorescência da clorofila $a$ e de produção dos genótipos de feijãocaupi sob irrigação deficitária. A fixação de carbono no metabolismo fotossintético de plantas de feijão-caupi é reduzida com déficit hídrico acentuado, independente do genótipo. A baixa severidade do estresse foi indicada pela inexistência de efeitos sobre a fluorescência da clorofila, indicando que a redução na taxa de assimilação de carbono se deveu aos efeitos estomáticos. A irrigação com $80 \%$ da Etc pode ser utilizada no cultivo das respectivas cultivares, porém com pequenas perdas na produção. Entre os genótipos de feijão, o 'BRS Marataoã' destaca-se quanto à produtividade com maiores valores para peso de vagem e grãos verdes.

Palavras-chave: fisiologia, reposição hídrica, trocas gasosas, Vigna unguiculata.

\section{INTRODUCTION}

Cowpea (Vigna unguiculata L.), also known as 'feijão-de-corda' or 'feijão-macassar', is the main subsistence crop in the North and Northeast regions of Brazil, standing out as the main source of protein in the diet of people of this region. Recently, the cowpea crop started to be cultivated also in the dry period under irrigation, especially in the Northeast region of the country (Nascimento et al., 2011).

In Northeast Brazil, the prominent climatic features are a remarkable aspect, particularly the rainfalls concentrated in short periods of the year, low relative air humidity and high temperatures. In this region, irrigation management strategies associated with the resistance of the crops to drought and the utilization of species tolerant to water stress allow an alternative production of the crop under water scarcity (Figueiredo et al., 2008; Ferraz et al., 2011).

Under these conditions, the need for studies aiming to identify genotypes adapted to distinct edaphoclimatic conditions becomes evident, in order to have positive results in the cultivation of the crop, thus leading to improvements in production and higher profitability for the producers (Lemos et al., 2004). According to FLOSS (2004), approximately $90 \%$ of the biological production of the crop occurs in response to photosynthetic activity and $60 \%$ of the global cowpea production comes from regions with water deficit, which makes it the second largest cause of reduction in the yield of the crop (Singh, 1995).

Among various abiotic stresses that affect the cowpea crop, water deficit stands out for its large area of occurrence and its role in yield reduction, reduction of stomatal conductance and increase of diffusive resistance to water vapor through stomatal closure, reduction of transpiration and, consequently, the $\mathrm{CO}_{2}$ supply for photosynthesis (Oliveira et al., 2005; Muñoz-Perea et al., 2006; Dutra et al., 2015). However, the responses of the crop to water stress 
vary according to the species, cultivar, duration of exposure and edaphic factors. In addition, the physiological variables alone do not constitute an indication of tolerance to drought, requiring studies that evaluate plant physiology and production under stress, to identify tolerant genotypes. This study therefore aimed to evaluate the photosynthetic efficiency and production of cowpea genotypes under deficit irrigation replacement levels.

\section{MATERIAL AND METHODS}

The research was a field study in the experimental area of the Fruticulture and Plant Ecophysiology Sector, at the Center of Human and Agrarian Sciences (CCHA), Campus IV of the State University of Paraíba (UEPB), located in the municipality of Catolé do Rocha, PB, Brazil. The city is situated at latitude $6^{\circ} 21^{\prime}$ ' $S$ and longitude $37^{\circ} 48^{\prime} \mathrm{W}$, at an altitude of $250 \mathrm{~m}$.

The climate of the region is BSw'h', according to Köppen's classification, characterized as hot semi-arid, with two different seasons, a rainy one with irregular rainfall and another one without rainfall. The mean annual rainfall is $870 \mathrm{~mm}$, and the mean temperature is $27^{\circ} \mathrm{C}$ with a rainy period concentrated between February and April, and a maximum temperature of $35^{\circ} \mathrm{C}$ and a minimum of $19^{\circ} \mathrm{C}$.

The study was carried out from September 19 to December 12, 2012, which corresponds to the drought period in this region, requiring the use of irrigation for the crop.

In the locality, the edaphic conditions were represented by a soil classified as typic eutrophic Tb FLUVIC NEOSOL with sandy loam texture (sand $=773.7$; silt $=168.3$ and clay $=58 \mathrm{~g} \mathrm{~kg}^{-1}$ ), with soil density $=1.53$ and particle density $=2.53 \mathrm{~g} \mathrm{~kg}^{-1}$, porosity of $42.26 \%$ and moisture at field capacity and permanent wilting point of 114.4 and $35.1 \mathrm{~g} \mathrm{~kg}^{-1}$, respectively. The mean results of the chemical analyses, before installing the experiment, were: $\mathrm{pH}$ in $\mathrm{H}_{2} \mathrm{O}(1: 2.5)=7.32 ; \mathrm{P}=186.97$ and $\mathrm{K}=309.08 \mathrm{mg} \mathrm{dm}^{-3} ; \mathrm{Ca}=4.8 ; \mathrm{Mg}=1.55$; $\mathrm{Na}=0.404 ; \mathrm{Al}=0.0 ; \mathrm{H}+\mathrm{Al}=0.413 ; \mathrm{SB}=7.54 ; \mathrm{CEC}=7.96 \mathrm{cmolc}^{-3}$ and $\mathrm{OM}=12.62 \mathrm{~g} \mathrm{~kg}^{-1}$.

The experiment consisted of three cowpea cultivars, obtained from the cowpea genetic improvement program of Embrapa Mid-North with potential of production in the semi-arid region (G1 = 'BRS Aracé', G2 = 'BR 17 Gurguéia' and G3 = 'BRS Marataoã') and four irrigation depths (40,60, 80 and 100\% of ETc). Factorially combined, it resulted in a $3 \times 4$ factorial scheme, arranged in randomized complete block design with four replicates. The experimental units consisted of a zinc box with dimensions of $1.20 \times 1.20 \times 1.0 \mathrm{~m}$, containing 8 useful plants per box, totaling 288 experimental plants in a total area of $300 \mathrm{~m}^{2}$. Sowing of the cultivars was done manually, and three seeds were distributed per hill at a spacing of $0.50 \times 0.20 \mathrm{~m}$. At 15 days after sowing (DAS) plants were thinned, leaving five plants per linear meter.

Soil tillage consisted of one plowing with disc harrow, which turned the soil to a depth of $0.20 \mathrm{~cm}$, and subsequent leveling with a leveling harrow. Fertilizers were applied according to the soil analysis, for the cowpea crop. Fertilizer application was the same for all treatments using mineral fertilizers with NPK, in the form of urea $(45 \% \mathrm{~N})$, single superphosphate $\left(22 \% \mathrm{P}_{2} \mathrm{O}_{5}\right)$ and potassium chloride $\left(60 \% \mathrm{~K}_{2} \mathrm{O}\right)$.

Irrigation management was based on the soil water depletion level relative to the treatment, determined through the reference evapotranspiration (ETo) by the Penman-Monteith method (Allen et al., 1998), based on data from the existing meteorological station in the experimental area, to determine the evapotranspiration of the culture (ETc = ETo x Kc), using the Kc proposed by Doorenbos and Kassan (1979), in the different crop development stages: germination - primary leaves (V0 - V2), Kc from 0.30 to 0.40 ; first trifoliate leaf - third trifoliate leaf (V3 - V4), Kc from 0.70 to 0.80; pre-flowering - pod formation (R5 - R7), Kc from 1.05 to 1.20; grain filling (R8) and maturation (R9), Kc from 0.25 to 0.30 . These data were used to 
calculate the gross irrigation depth, application intensity and irrigation time.

Internal $\mathrm{CO}_{2}$ concentration $(C i)\left(\mu \mathrm{mol} \mathrm{m} \mathrm{m}^{-2} \mathrm{~s}^{-1}\right)$, transpiration $(E)\left(\mathrm{mmol} \mathrm{H}_{2} \mathrm{O} \mathrm{m}^{-2} \mathrm{~s}^{-1}\right)$, stomatal conductance $(g s)\left(\mathrm{mol} \mathrm{H}_{2} \mathrm{Om}^{-2} \mathrm{~s}^{-1}\right)$ and net photosynthesis $(A)$ were evaluated and the readings were taken between 8:40 and 9:40 $\mathrm{h}$ in the morning at 22 days after sowing (V5 vegetative stage). These data were used to quantify the instantaneous water use efficiency (IWUE) $(A / E)\left[\left(\mu \mathrm{mol} \mathrm{m}^{-2} \mathrm{~s}^{-1}\right)\left(\mathrm{mmol} \mathrm{H}_{2} \mathrm{O} \mathrm{m}^{-2} \mathrm{~s}^{-1}\right)^{-1}\right]$ and instantaneous carboxylation efficiency (A/Ci) (Silva et al., 2014). These measurements were taken in the third leaf of the central leaflet from the apex, fully expanded and without signs of senescence or herbivory, in two plants per plot, using an infrared gas analyzer (IRGA), Model LCpro+Sistem.

Fluorescence determinations were taken in 2-h intervals throughout the day on the same date of the readings of gas exchanges. The evaluations of initial fluorescence $(F o)$, maximum fluorescence $(F m)$, variable fluorescence $(F m-F o)$ and maximum quantum efficiency of photosystem II $(\mathrm{Fv} / \mathrm{Fm})$ were performed in the third intermediate leaf of the main branch of the evaluated plants of each plot, after being pre-adapted in the dark for 30 minutes, using a portable fluorometer (Hansatech).

After the phenological stage R3, characterized by the beginning of the change of color of the pods, considering that the grains were already completely formed, the pods were harvested, for later determination of the weight of green pods, length of green pods, number of grains by pod and weight of green grains. For weighing, a precision balance $\pm 0.01 \mathrm{~g}$.

The data of the variables were subjected to analysis of variance by $\mathrm{F}$ test $(\mathrm{P} \leq 0.05)$, while the regression models were fitted based on the coefficient of determination $(\alpha \leq 0.05)$ and the means were compared by Tukey test $(\alpha \leq 0.05)$, using the program SAEG 9.1.

\section{RESULTS AND DISCUSSION}

For the variables internal $\mathrm{CO}_{2}$ concentration, stomatal conductance, photosynthesis, instantaneous water use efficiency and instantaneous carboxylation efficiency was significant influenced by irrigation levels (Figure 1A, B, C, D e E). The transpiration rate was not influenced by the treatments.

The internal $\mathrm{CO}_{2}$ concentration ( $\mathrm{Ci}$ ) suffered significant effect of the irrigation depths, with highest gas accumulation $\left(191.16 \mu \mathrm{mol} \mathrm{mol}^{-1}\right)$ in cowpea plants cultivated under highest stress ( $40 \%$ of ETc) (Figure 1A). On the other hand, there was a slight variation in the $C i$ rates with the increase of water availability in the soil, after applying water depths of 40 to $100 \%$ ETc. It should be pointed out that $\mathrm{Ci}$ accumulation in the leaf mesophyll is directly associated with stomatal closure and reduction in $\mathrm{CO}_{2}$ assimilation (Paiva et al., 2005). Souza et al. (2016) also observe this fact, in cowpea cv. BRS Punjante, where the increase of $\mathrm{Ci}$ concentration in the lower levels of water availability corroborated with the lower levels of photosynthesis.

For stomatal conductance ( $g s$ ), there was a reduction of $30.30 \%$ to the critical value of $0.2861 \mathrm{~mol} \mathrm{~m}^{-2} \mathrm{~s}^{-1}$ obtained with the replacement of $40 \%$ ETc after a water stress period of $24 \mathrm{~h}$ for all cowpea genotypes studied ('BRS Aracé', 'BR17 Gurguéia' and 'BRS Marataoã') (Figure 1B). Such reduction in gs was obtained in relation to the highest conductance among the means $\left(0.3728 \mathrm{~mol} \mathrm{~m}^{-2} \mathrm{~s}^{-1}\right)$, relative to the highest irrigation depth $(100 \% \mathrm{ETc})$. Since $g s$ is responsible for almost all activities of the internal and external factors of the plant related to water deficit, it is a highly integrative factor for the global effect of water stress on the physiological parameters (Singh and Reddy, 2011; Silva et al., 2014).

For net photosynthesis $(A)$, the decrease from $100 \%$ irrigation to deficit irrigation of $40 \%$ ETc caused linear reductions in the photosynthetic rates of the cowpea plants. The highest value of photosynthetic rate was $23.57 \mu \mathrm{mol}$ of $\mathrm{CO}_{2} \mathrm{~m}^{-2} \mathrm{~s}^{-1}$, observed in plants under irrigation of $100 \%$ ETc, and the lowest value $\left(19.32 \mu \mathrm{mol} \mathrm{CO} \mathrm{C} \mathrm{m}^{-2} \mathrm{~s}^{-1}\right)$ was obtained in plants under deficit irrigation of 40\% ETc (Figure 1C). According to Taiz and Zeiger (2013), such reduction in net 
photosynthesis under water deficit is partially associated with the high temperatures and low relative air humidity, which are peculiar characteristics of the climate of the semi-arid region of Paraíba, where the research was conducted.

A
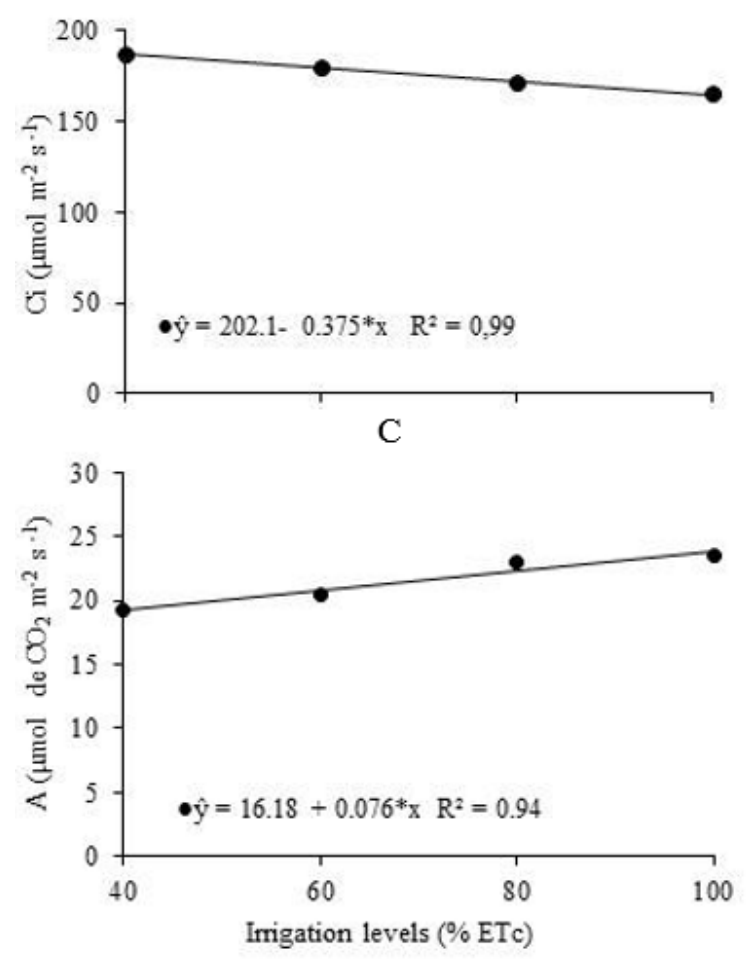

B
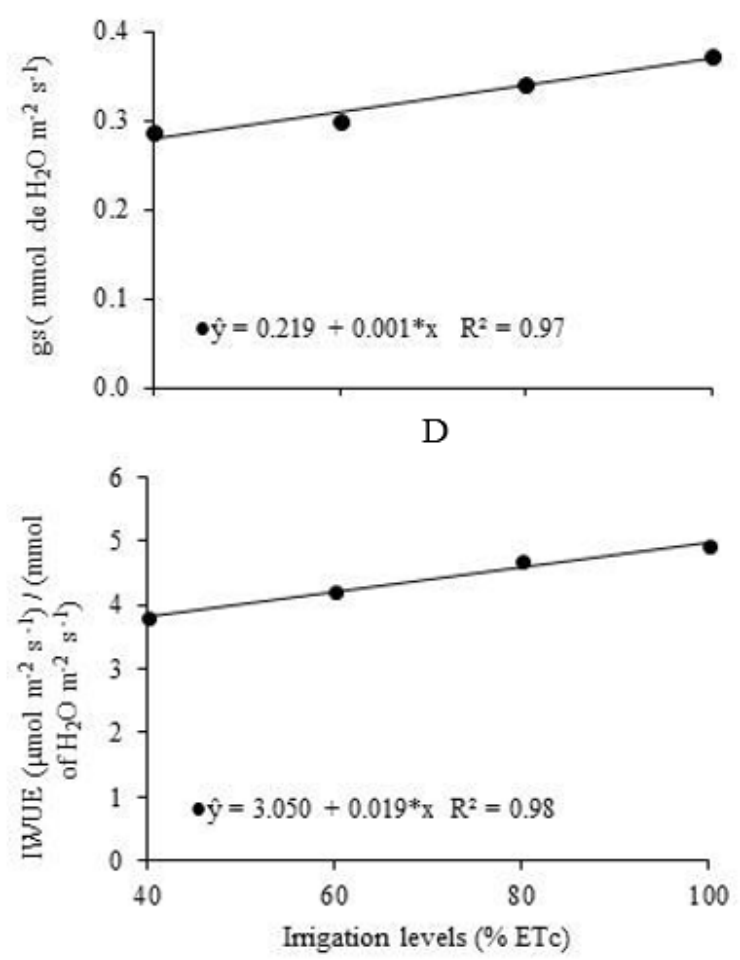

$\mathrm{E}$

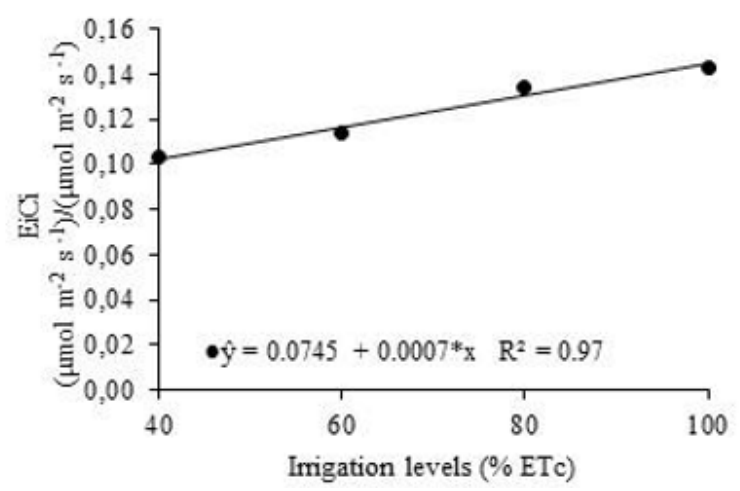

Figure 1. Internal $\mathrm{CO}_{2}$ concentration, $\mathrm{Ci}$ (A), stomatal conductance, gs (B), net photosynthesis, $A$ (C), instantaneous water use efficiency, IWUE (D) and instantaneous carboxylation efficiency, EiCi (E) of cowpea genotypes under irrigation depths.

The irrigation depths differed significantly for the variable instantaneous water use efficiency (IWUE), with reductions on the order of $29.55 \%$ between the highest value of $4.90\left[\left(\mu \mathrm{mol} \mathrm{m}^{-2} \mathrm{~s}^{-1}\right) /\left(\mathrm{mmol} \mathrm{H}_{2} \mathrm{O} \mathrm{m}^{-2} \mathrm{~s}^{-1}\right)\right]$ at the irrigation depth of 100\% ETc and the lowest value of $3.78\left[\left(\mu \mathrm{mol} \mathrm{m} \mathrm{s}^{-2}\right) /\left(\mathrm{mmol} \mathrm{H}_{2} \mathrm{O} \mathrm{m}^{-2} \mathrm{~s}^{-1}\right)\right]$ recorded at the lowest irrigation depth, $40 \%$ ETc (Figure 1D). The assimilation of $\mathrm{CO}_{2}$ from the external environment leads to water loss and the decrease in this loss also restricts the $\mathrm{CO}_{2}$ entry (Shimazaki et al., 2007). Thus, the increments observed in IWUE, notably at irrigation depths of 40 to 100\% ETc, are reflexes of the increases observed in the net photosynthetic rate $(A)$ of the cowpea plants.

The instantaneous carboxylation efficiency (EiCi) was affected by the application of irrigation depths, with the increase from 40 to $100 \%$ ETc. The highest EiCi (0.1429) occurred

\section{IPABH}


in plants irrigated with $100 \%$ ETc, contrasting with the lowest value of 0.1031 observed at the lowest irrigation depth (40\% ETc), which represented a reduction of 38.60\% (Figure 1E). Brito et al. (2012), evaluating the physiological behavior of citrus plants in protected environment under water replacement levels, observed that high values of internal $\mathrm{CO}_{2}$ concentration associated with the increase in stomatal conductance indicate an increment in the instantaneous carboxylation efficiency, due to the availability of ATP and NADPH and of the substrate for Ribulose-1,5-bisphosphate carboxylase/oxygenase (RuBisCO). This fact may have occurred in the present study because of the increase of photosynthesis and stomatal conductance and reduction of the internal concentration of $\mathrm{CO}_{2}$ under the greater availability of water (Figure 1).

There was no significant influence on the variables of chlorophyll a fluorescence, with mean values of 330, 1739 and 1335 electrons quantum $^{-1}$ for Fo, Fm and Fv, respectively, and 0.77 for quantum efficiency of PSII, which indicate absence of damages to the photosynthetic apparatus (Baker and Rosenqvst, 2004). This indicates that the reductions in the photosynthetic capacity of the studied cultivars were mainly of stomatal origin.

For the variable Length of green pods, significant $(\mathrm{p}<0.05)$ influence of irrigation levels was observed (Figure 2A). However, for weight of green pods, number of green beans and weight of green beans (WGB) significant $(\mathrm{p}<0.05$ ) influence of cowpea cultivars was observed (Figures 2B, C and D).

For the length of green pods (LGP), there was an increasing linear behavior as the water availability increased, with lowest value $(13.3 \mathrm{~cm})$ for the application of $40 \%$ ETc and highest value $(15.9 \mathrm{~cm})$ for the maximum water content in the soil $(100 \%$ ETc). There was an increment of $20 \%$ at this irrigation depth and no difference between the studied genotypes (Figure 2A), denoting that the water stress has direct influence on cowpea production, affecting the growth and filling of the pods and, consequently, of the grains.

For the variables weight of green pods (WGP) and weight of green beans (WGB), the genotype 'BRS Marataoã' exhibited a superior behavior compared with the others, with $6 \mathrm{~g}$ for WGP and $3.46 \mathrm{~g}$ for WGB, showing mean differences of 41 and $43 \%$ in relation to the values obtained by the genotypes 'BRS Aracé' (4.26 and 2.59) and 'BR17 Gurguéia' (4.23 and 2.83 g), respectively (Figures $2 \mathrm{~B}$ and $\mathrm{D}$ ). This reduction in the weight of pods and beans has direct influence on the yield of green beans and indicates that it is related to the reduction in soil water content, which means that the lowest values of growth, photosynthesis and biochemical components also reflect in the production characteristics of cowpea plants. Hence, there is a reduction of conductance and leaf transpiration in the plant and, consequently, an increment in leaf temperature and reduction in the production of photoassimilates, causing reduction in the production components and final yield.

For the variable number of green beans (NGB), the genotype 'BR17 Gurguéia' showed the highest mean values for beans per pod (11.5 beans), four more in comparison to the cultivar 'BRS Aracé' ( 7.5 beans) (Figure 2C). The results were similar to those obtained by Mendes et al. (2007), working with the source-sink relationships in cowpea for the production of dry beans subjected to water deficit. These authors found that water stress applied in both vegetative and reproductive stages leads to significant reduction in number of beans per pod. 
A

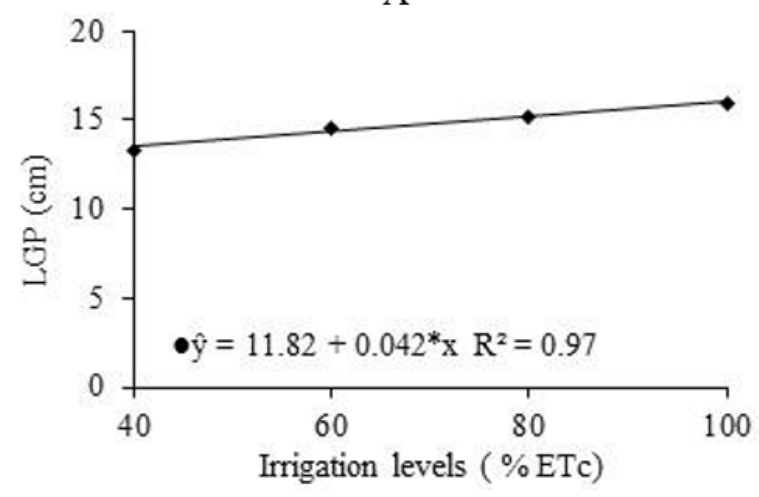

$\mathrm{C}$

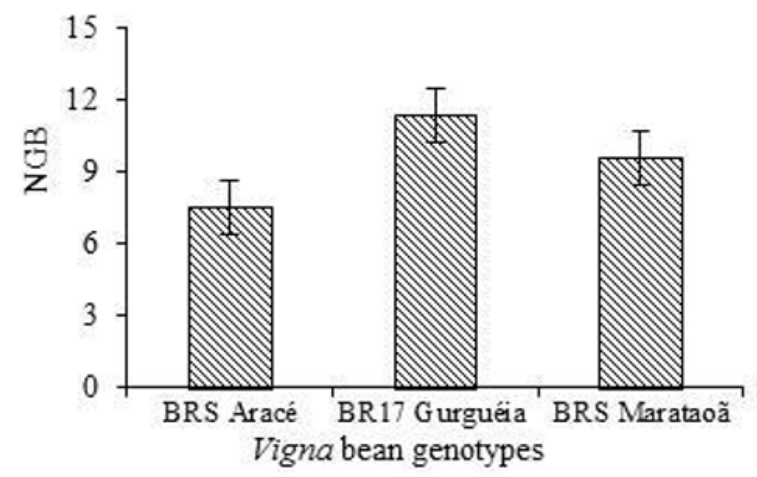

B

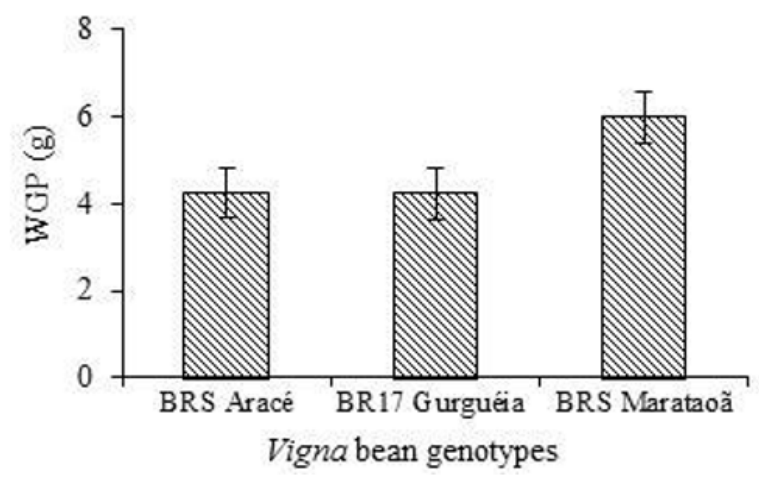

$\mathrm{D}$

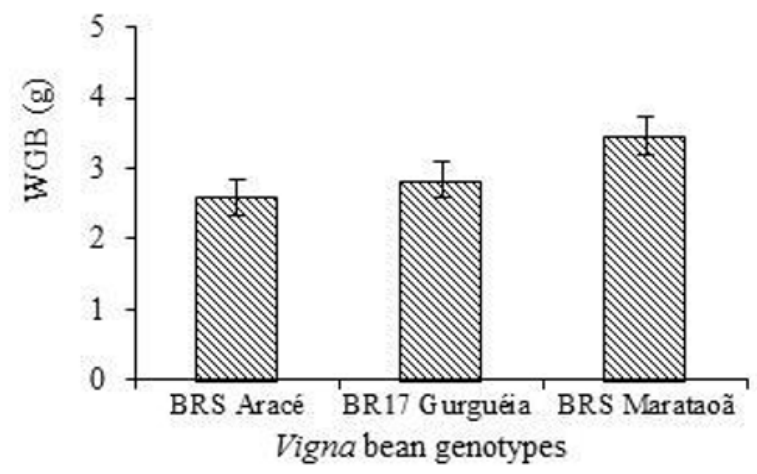

Figure 2. Length of green pods, LGP (A), weight of green pods, WGP (B), number of green beans, NGB (C) and weight of green beans, WGB (D) of cowpea genotypes under irrigation depths.

\section{CONCLUSIONS}

Carbon fixation in the photosynthetic metabolism of cowpea plants is reduced with accentuated water deficit, regardless of the genotype.

Low stress severity was indicated by the lack of effects on chlorophyll fluorescence, indicating that the reduction in the rate of carbon assimilation was due to the stomatal effects.

Irrigation with $80 \%$ of the ETc can be used in the cultivations of the respective cultivars, but with small losses in production.

Among the genotypes, 'BRS Marataoã' stands out with respect to the yield, with higher values for weight of pods and green beans.

\section{REFERENCES}

ALLEN, R. G.; PEREIRA, L. S.; RAES, D.; SMITH, M. Crop evapotranspiration: guidelines for competing crop water requirements. Roma: FAO, 1998. 300p. (Irrigation and Drainage, Paper 56).

BAKER, N. R.; ROSENQVIST, E. Applications of chlorophyll fluorescence can improve crop production strategies: an examination of future possibilities. Journal of Experimental Botany, v. 55, p. 1607-1621, 2004.

BRITO, M. E. B.; SOARES, L. A. A.; FERNANDES, P. D.; LIMA, G. S.; SÁ, F. V. S.; MELO, A. S. Comportamento fisiológico de combinações copa/porta-enxerto de citros sob estresse hídrico. Revista Brasileira de Ciências Agrárias, v. 7, p. 857-865, 2012.

DOORENBOS, J.; KASSAN, A. H. Efectos del água en rendimento de los cultivos. Roma: FAO, 1979. 212p. (Boletim Riego y Drenaje, 33).

\section{IPABH}


DUTRA, A. F.; MELO, A. S.; FILGUEIRAS, L. M. B.; SILVA, A. R. F.; OLIVEIRA, I. M.; BRITO, M. E. B. Parâmetros fisiológicos e componentes de produção de feijão-caupi cultivado sob deficiência hídrica. Revista Brasileira de Ciências Agrária, v. 10, p. 189-197, 2015.

FERRAZ, R. L. S.; MELO, A. S.; SUASSUNA, J. F.; BRITO, M. E. B.; FERNANDES, P. D.; NUNES JÚNIOR, E. S. Trocas gasosas e eficiência fotossintética em ecótipos de feijoeiro cultivados no semiárido. Revista Ciência Agronômica, v. 42, p. 957-964, 2011.

FIGUEIREDO, M. G.; FRIZZONE, J. A.; PITELLI, M. M; REZENDE, R. Lâmina ótima de irrigação do feijoeiro, com restrição de água, em função do nível de aversão ao risco do produto. Acta Scientiarum Agronomy, v. 30, p. 81-87, 2008.

FLOSS, E. L. Fisiologia das plantas cultivadas. Passo Fundo: UPF, 2004.

LEMOS, L. B.; OLIVEIRA, R. S.; PALOMINO, E. C.; SILVA, T. R. B. Características agronômicas e tecnológicas de genótipos de feijão do grupo comercial carioca. Pesquisa Agropecuária Brasileira, v. 39, p. 319-326, 2004.

MENDES, R. M. S.; TÁVORA, F. J. A. F.; PINHO, J. L. N.; PITOMBEIRA, J. B. Relações fontedreno em feijão-de-corda submetido à deficiência hídrica. Ciência Agronômica, v. 38, p. 95103, 2007.

MUÑOZ-PEREA, C. G.; TERÁN, H.; ALLEN, R. G.; WRIGHT, J. L.; WESTERMANN, D. T.; SINGH, S. P. Selection for drought resistance in dry bean landraces and cultivars. Crop Science, v. 46, p. 2111-2120, 2006.

NASCIMENTO, S. P. N.; BASTOS, E. A.; ARAUJO, E. C. E.; FILHO, F. R. F.; SILVA, E. M. Tolerância ao déficit hídrico em genótipos de feijão - caupi. Revista Brasileira de Engenharia Agrícola e Ambiental, v. 15, p. 853-860, 2011.

OLIVEIRA, A. D.; FERNANDES, E. J.; RODRIGUES, T. J. D. Condutância estomática como indicador de estresse hídrico em Feijão. Engenharia Agrícola, v. 25, p. 86-95, 2005.

PAIVA, A. S.; FERNANDES, E. J.; RODRIGUES, T. J. D.; TURCO, J. E. P. Condutância estomática em folhas de feijoeiro submetido a diferentes regimes de irrigação. Engenharia Agrícola, v. 25, p. 161-169, 2005.

SHIMAZAKI, K. I.; DOI, M.; ASMANN, S. M.; KINOSHITA, T. Light regulation of stomatal movement. Annual Review of Plant Biology, v. 58, p. 219-247, 2007.

SILVA, L. A. S.; BRITO, M. E. B.; SÁ, F. V. S.; MOREIRA, R. C. L. M.; SOARES FILHO, W. $\mathrm{S}$. et al. Mecanismos fisiológicos em híbridos de citros sob estresse salino em cultivo hidropônico. Revista Brasileira de Engenharia Agrícola e Ambiental, v. 18, p. S1-S7, 2014.

SINGH, S. K.; REDDY, K. R. Regulation of photosynthesis, fluorescence, stomatal conductance and water-use efficiency of cowpea (Vigna unguiculata [L.] Walp.) under drought. Journal of Photochemistry and Photobiology B: Biology, v. 105, p. 40-50, 2011.

SINGH, S. P. Selection for water-stress tolerance in interracial populations of common bean. Crop Science, v. 35, p. 118-124, 1995.

SOUZA, T. M. A.; SOUZA, T. A.; SOLTO, L. S.; SÁ, F. V. S.; PAIVA, E. P.; BRITO, M. E. B. et al. Crescimento e trocas gasosas do feijão-caupi cv. BRS Pujante sob níveis de água disponível no solo e cobertura morta. Irriga, v. 21, p. 796-805, 2016.

TAIZ, L.; ZEIGER, E. Fisiologia vegetal. 5. ed. Porto Alegre: Artmed, 2013. 918p. 


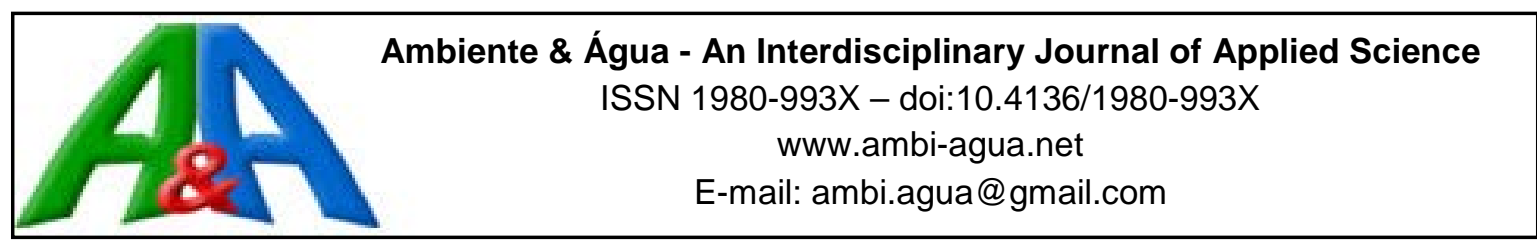

\title{
Use of statistical multivariate analysis to identify sources emitting particulate matter in Belo Horizonte, Brazil
}

\author{
ARTICLES doi:10.4136/ambi-agua.2202
}

Received: 23 Oct. 2017; Accepted: 11 Jun. 2018

\section{Igor Felipe Silva Moura' ${ }^{*}$; Alberto Avellar Barreto²; Raisa Helena Sant'Ana Cesar²; Ananda Borjaille Cruz²; Maria Ângela de Barros Correia Menezes ${ }^{1,3}$

\author{
${ }^{1}$ Universidade Federal de Minas Gerais (UFMG), Belo Horizonte, MG, Brasil \\ Departamento de Engenharia Nuclear (DEN).E-mail: igorfelipedx@ufmg.br, menezes@cdtn.br \\ ${ }^{2}$ Centro de Desenvolvimento da Tecnologia Nuclear (CDTN), Belo Horizonte, MG, Brasil \\ Departamento de Serviço de Meio Ambiente (SEMAM). E-mail: aab@cdtn.br, \\ raisa.cesar@cdtn.br, nandy.borjaille@hotmail.com \\ ${ }^{3}$ Centro de Desenvolvimento da Tecnologia Nuclear (CDTN), Belo Horizonte, MG, Brasil \\ Serviço de Técnicas Analíticas (SERTA). E-mail: menezes@cdtn.br \\ ${ }^{*}$ Corresponding author
}

\begin{abstract}
Particulate matter is the mixture of solid and liquid particles. It may at times cause adverse effects to human health, in the climate, ecosystem and materials. The objective of this study was to identify the sources emitting particulate matter that contributes to environmental pollution at two sites in Belo Horizonte city. The metropolitan region of Belo Horizonte is characterized by numerous mining activities and other industries, high population and, consequently, a high number of vehicles. There are therefore several sources emitting pollutants into the atmosphere. Airborne particulate matter was collected in air filters during approximately one year using a high-volume sampler in strategic points. The concentration of particulate matter results showed that, in general, the values were $40 \%$ higher than the values recommended by legislation. During the summer rainy season, no sample exceeded the recommended limits at both sampling sites. The elemental composition was determined through neutron activation analysis and these values were considered variables in the multivariate statistical analysis for the identification of the main sources of particle emission and their contributions. The results confirmed a significant influence of the soil and motor vehicles in the degradation of the region's air quality.
\end{abstract}

Keywords: airborne particulate matter, air quality, environmental monitoring, multivariate statistics analysis, neutron activation analysis.

\section{Identificação de fontes emissoras de material particulado na cidade de Belo Horizonte (Brasil) através da análise estatística multivariada}

\section{RESUMO}

O material particulado é a mistura de partículas sólidas e líquidas, causando efeitos adversos na saúde humana, no clima, no ecossistema e nos materiais. O objetivo deste estudo foi identificar as fontes emissoras de material particulado que contribuem para a poluição ambiental em dois locais da cidade de Belo Horizonte. A região metropolitana de Belo 
Horizonte é caracterizada por inúmeras atividades de mineração e outras indústrias, grande população e, consequentemente, um elevado número de veículos, ou seja, diversas fontes emissoras de poluentes na atmosfera. As partículas suspensas no ar foram coletadas no filtro de ar durante aproximadamente um ano usando um amostrador de grande volume em pontos estratégicos. A concentração de material particulado apontou que, em geral, os valores foram $40 \%$ superiores aos valores recomendados pela legislação. No verão, a estação chuvosa, nenhuma amostra excedeu os limites recomendados em ambos os locais de amostragem. A composição elementar foi determinada através da análise de ativação neutrônica e estes valores foram considerados variáveis na análise estatística multivariada para a identificação das principais fontes emissoras de partículas e suas contribuições. Os resultados confirmaram uma influência significativa do solo e veículos motorizados na degradação da qualidade do ar da região.

Palavras-chave: análise estatística multivariada, análise por ativação neutrônica, material particulado, monitoramento ambiental, qualidade do ar.

\section{INTRODUCTION}

Changes in the natural air constituents may negatively affect plant and animal species, as well as human health and well-being (CONAMA, 1990). The air quality standards established by the World Health Organization (WHO) and national councils such as the National Environment Council (CONAMA) and the State of Minas Gerais Environment Foundation (FEAM) are based on political, social and economic issues, as well as health risk factors and national capacity for air quality management (CONAMA, 1990; FEAM, 2017; WHO, 2006).

Industrial activities generate a large volume of waste that is emitted to the atmosphere, containing several compounds harmful to human health (Brasil et al., 2007). Automobiles are one of the greatest sources of pollution developed by man, and release gases and particles into the atmosphere that alter its natural composition (Albuquerque et al., 2012; Sharma and Khare, 2001). This activity has had a significant impact on air quality, since over the years the number of vehicles has been growing sharply (Nagendra and Khare, 2002; Tavares et al., 2014).

One of the major pollutants released into the atmosphere is particulate matter (PM), which is the mixture of solid and liquid particles that vary in shape and chemical composition, and cause adverse effects on human health, and to the climate, ecosystem and materials (Kappos et al., 2004).

Some elemental traits can cause biological effects, such as inflammation, allergies and DNA damage, generating free radicals in human body tissues (HEI, 2002). The PM composition in the atmosphere depends on emission factors that occur in each region, such as the occurrence of fires, mining activities, automotive vehicle flow or industrial activities (Calijuri and Cunha, 2013), as well as the processes of PM resuspension by natural or artificial agents. Further, PM can be emitted from several sources, fixed or mobile, presenting varied chemical composition (Adissi et al. 2013). Monitoring air quality is essential to the control of air pollution.

The use of monitoring networks associated with computational modeling resources is fundamental to monitoring the evolution of pollutant dispersions and thereby obtaining support for the elaboration of public environmental policies (CETESB, 2015; FEAM, 2017).

Techniques based on monitoring networks allow the investigation of local conditions of air quality. The equipment used is costly and requires operating conditions and adequate structure for sampling at specific points. The generated environmental data are used mainly for statistical analyses on which strategies to identify the main contributing sources of pollution at the monitored site are based (Tavares et al., 2014).

The main statistical tool used to aid and interpret air quality monitoring data (Rebelo et al., 
2015) is the Principal Component Analysis (PCA). Many studies, use PCA to assess the impact of pollutants in the atmosphere and in the environment (Almeida et al., 2017; Elbayoumi et al., 2014; Jacomino et al., 2009; Megido et al., 2017; Sánches-Rodas et al., 2017).

This work therefore assessed air pollution in Belo Horizonte, the capital of the state of Minas Gerais, Brazil, at two sites located on the campus of Federal University of Minas Gerais, in order to identify sources emitting $\mathrm{PM}_{10}$. The elemental composition of airborne particulate matter was analyzed through neutron activation analysis in order that PCA could be used to identify the main sources of $\mathrm{PM}_{10}$ emission.

\section{MATERIALS AND METHODS}

Sampling of $\mathrm{PM}_{10}$ was performed in the northeast region of Belo Horizonte. The city has a territorial area of 331,401 km², and an estimated population for the year 2017 of 2,523,794 inhabitants (IBGE, 2016). It is 900 meters above sea level and its temperature varies between $16^{\circ} \mathrm{C}$ to $31^{\circ} \mathrm{C}$. The climate is a humid subtropical climate, registering rainfall and high temperatures in summer, while winter is characterized by low rainfall and low temperatures (Belo Horizonte, 2016).

The metropolitan region of Belo Horizonte is characterized by numerous mining activities and other industries, and is highly populated. Because the high population density, there is a high number of vehicles and consequent traffic jams and high emissions of pollutants into the atmosphere.

The area studied, the campus of the Federal University of Minas Gerais (UFMG) is the second largest in terms of the circulation of people in the city of Belo Horizonte, with an estimated 55,000 people circulating daily. This movement causes transportation problems as described in the UFMG Technical Report (UFMG, 2010).

The first step of this work was the selection of PM sampling points. An assessment of the study area was performed in order to identify points exposed to various emission sources, both of natural origin (soil, vegetation, etc.), as well as anthropogenic sources (vehicle and industrial emissions). The proximity to access routes containing high vehicular flow was a factor, due to the urban characteristics of the study area. Based upon these considerations and the surroundings of the region and the main routes of the neighborhood, two points were selected as shown in Figure 1. Point 1 is in an area that includes an ecological preservation site and local transit routes (Coordinate Latitude 1952'19.53" S and Longitude 4358'15.14" W); Point 2 is on the margin of one of the main avenues of Belo Horizonte with intense vehicular flow (Coordinate Latitude 1951'47.32" S and Longitude 4357'30.27" W).

Several methods have been applied for PM monitoring. A technique widely used throughout the world is based on the High Volume Sampler (HVS), which uses a filter to retain particulate matter, sampling over a 24-hour period (USEPA, 1999). In this work, glass fiber filters were used to collect trace elements contained in suspended particulates in the air (Pöykiö et al., 2003). The HVS has an inertial impact separation head at a flow rate of $1.13 \mathrm{~m}^{3} \mathrm{~min}^{-1}$. The flow uncertainty is less than 1\% (ENERGÉTICA, 2012). For this study, only one high sampler was available. The equipment was therefore placed for few days at Point 1 and on other days at Point 2.

At Point 1 , due to the presence of animals in the area of ecological preservation and the inclination of the terrain, it was necessary to delimit and elevate the equipment by 1.2 meters (Figure 1). The elevation of the equipment did not interfere with the sampling. It is important to mention that in both sampling points, in order to avoid the resuspension of dust, a bulkhead was placed in the inferior part of the equipment. 


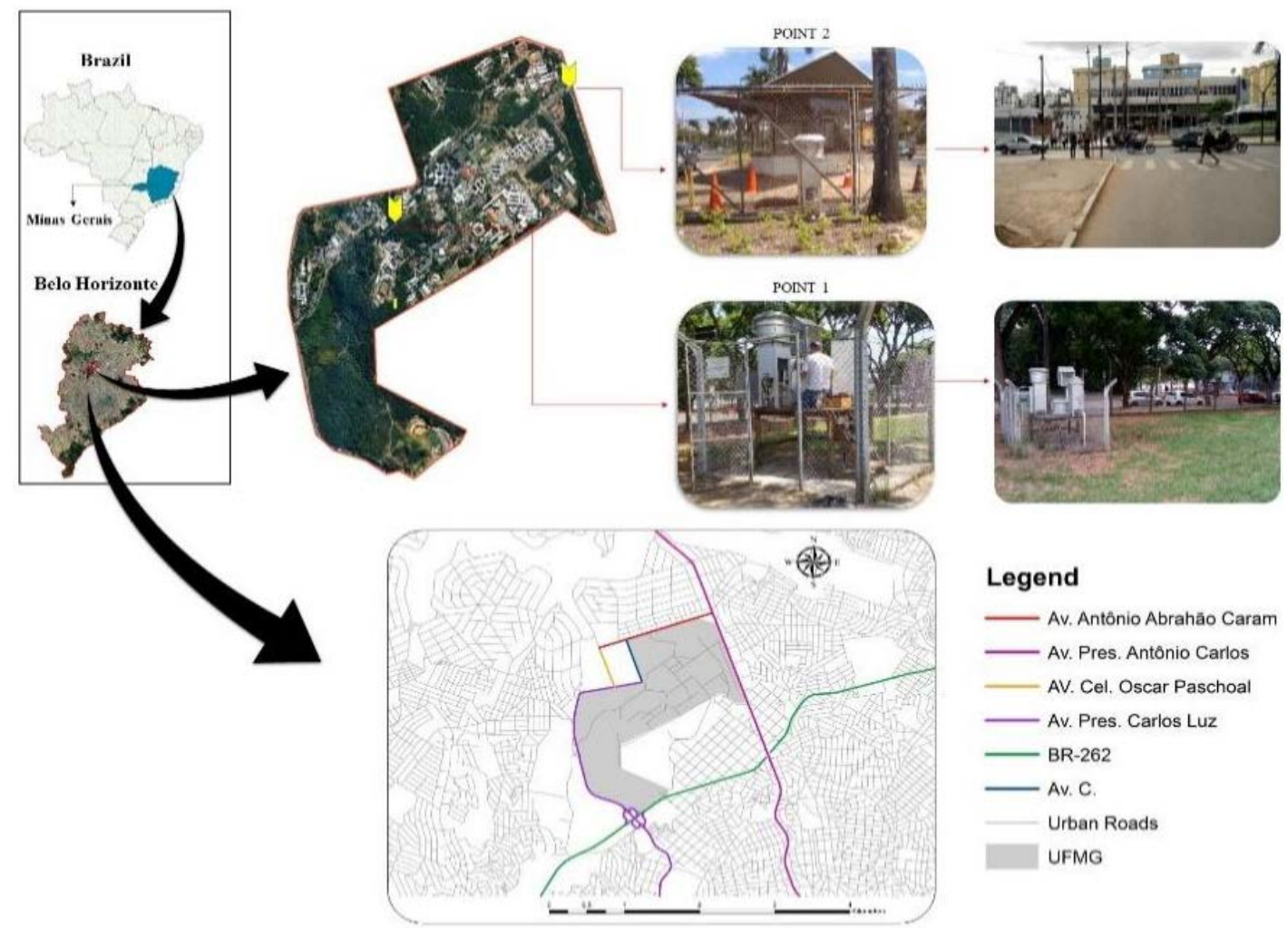

Figure 1. $\mathrm{PM}_{10}$ Sampling sites at the Federal University of Minas Gerais.

Before each sampling procedure, the equipment was calibrated to ensure the required flow rate. Samplings were performed using a filter for the retention of particulate during a 24-hour period. The filter model used for monitoring and determining the concentration of PM was the Whatman GF/A fiberglass type, with dimensions of $203 \times 254 \mathrm{~mm}$. Before the samplings, the filter was prepared by heating it in a muffle at $400^{\circ} \mathrm{C}$ for a period of 4 hours to eliminate moisture and organic compounds, and it was later stored in a desiccator to avoid contact with air humidity.

Before the sampling, each entire filter was weighed in a precision balance, with a maximum capacity of $210 \mathrm{~g}$ and a standard deviation of $0.1 \mathrm{mg}$.

After the sampling, the concentration (C) of PM, given in $\mu \mathrm{g} \mathrm{m}^{-3}$, was determined by the initial mass $\left(\mathrm{m}_{\mathrm{i}}\right)$, final mass $\left(\mathrm{m}_{\mathrm{f}}\right)$ and volume of the sampled air $\left(\mathrm{V}_{\mathrm{s}}\right)$ as shown in Equation 1 .

$C=10^{6} \cdot\left(\frac{m_{f}-m_{i}}{V_{s}}\right)$

The identification of elements present in the particulate matter was performed through Neutron Activation Analysis, which is a multielementar analytical technique to determine chemical elements in biological or geological material, effluent, oil, water and also in particulate matter (Menezes and Jacimovic, 2006). The sample is analyzed without being solubilized, a great advantage compared with other technical analytics that require that the sample is in a soluble form. In this study, the technique was applied via $k_{0}$-standardization method. This method does not use standards of the involved element but neutron monitors, gamma spectroscopy system absolutely calibrated, good knowledge of spectral parameters in the irradiation channel and $k_{0}$ constants available in literature. In this technique, the sample is bombarded by neutrons in a nuclear reactor and the radionuclides produced emit characteristic radiation formed in the $(n, \gamma)$ reaction. The chemical elements are then identified and assayed after irradiation by measurement - gamma spectrometry. 
The irradiation was carried out on the carousel of the TRIGA MARK I IPR-R1 reactor at CDTN (Nuclear Technology Development Centre) in Belo Horizonte, at $100 \mathrm{~kW}$, under an average thermal neutron flux of $6.30 \times 10^{11} \mathrm{~cm}^{-2} \mathrm{~s}^{-1}$. The averages parameters $f$ and $\alpha$ are $(21.7 \pm 1.1)$ and $(0.0026 \pm 0.0011)$, respectively. The samples were irradiated simultaneously with neutron flux monitor Al-Au (0.1\%) IRMM-530RA foil, cut into a $6 \mathrm{~mm}$ diameter $0.1 \mathrm{~mm}$ thick. The gamma spectroscopy was performed on an HPGe detector with 15\% efficiency and for the spectra analysis - peak area evaluation - the HyperLab program was used. For the calculation of elemental concentrations, a software package called Kayzero for Windows ${ }^{\circledR}$ was applied (Menezes and Jacimovic, 2006).

In this study, the sampled filter was cut into a fraction of $30 \mathrm{~cm}^{2}$ and packed in a polyethylene tube, $2.3 \mathrm{~cm}$ high and $1.1 \mathrm{~cm}$ in diameter, and then irradiated. In order to discount the influence of the filter material, the blank was prepared in triplicate under the same conditions.

Subsequently, Multivariate statistics was used, which is commonly applied in environmental studies, through principal component analysis (PCA), which analyzes multiple measurements of variables, with the objective of investigating, measuring, explaining and predicting relationships among statistical variables (Hair et al., 2009).

In the same way as PCA, Factorial Analysis (FA) describes the original vectors in a smaller number of variables, where they are called common factors and related to the original vector through the linear model (Mingoti, 2005). Through some rules, the quantity of factors according to Kaiser's criterion (Elbayoumi et al., 2014; Mingoti, 2005) refers to eigenvalues greater or equal to 1 , and many times it is necessary to carry out a rotation of these factors. One of the methods of rotation is the Varimax, which tries to find factors with great variability to better explain the PCA (Mingoti, 2005). Minitab Software was used for the execution and interpretation of statistical data.

\section{RESULTS AND DISCUSSION}

\subsection{Particulate Matter Concentration}

According to legislation (USEPA, 2014), air is considered to be of Good Quality when the concentration based on $\mathrm{PM}_{10}$, is lesser than $50 \mu \mathrm{g} \mathrm{m}^{-3}$; Moderate, when it is between 51 and $100 \mu \mathrm{g} \mathrm{m}^{-3}$; Unhealthy for Sensitive Groups, between 101 and $150 \mu \mathrm{g} \mathrm{m}^{-3}$; Unhealthy, between 151 and $200 \mu \mathrm{g} \mathrm{m}^{-3}$; Very Unhealthy, between 201 and $300 \mu \mathrm{g} \mathrm{m}^{-3}$; and above $301 \mu \mathrm{g} \mathrm{m}^{-3}$ is assessed as Hazardous. Figure 2 shows the concentration values for particulate matter collected from Point 1 and Point 2, the central tendency and variability of the data and their classification according to the values of US-EPA.

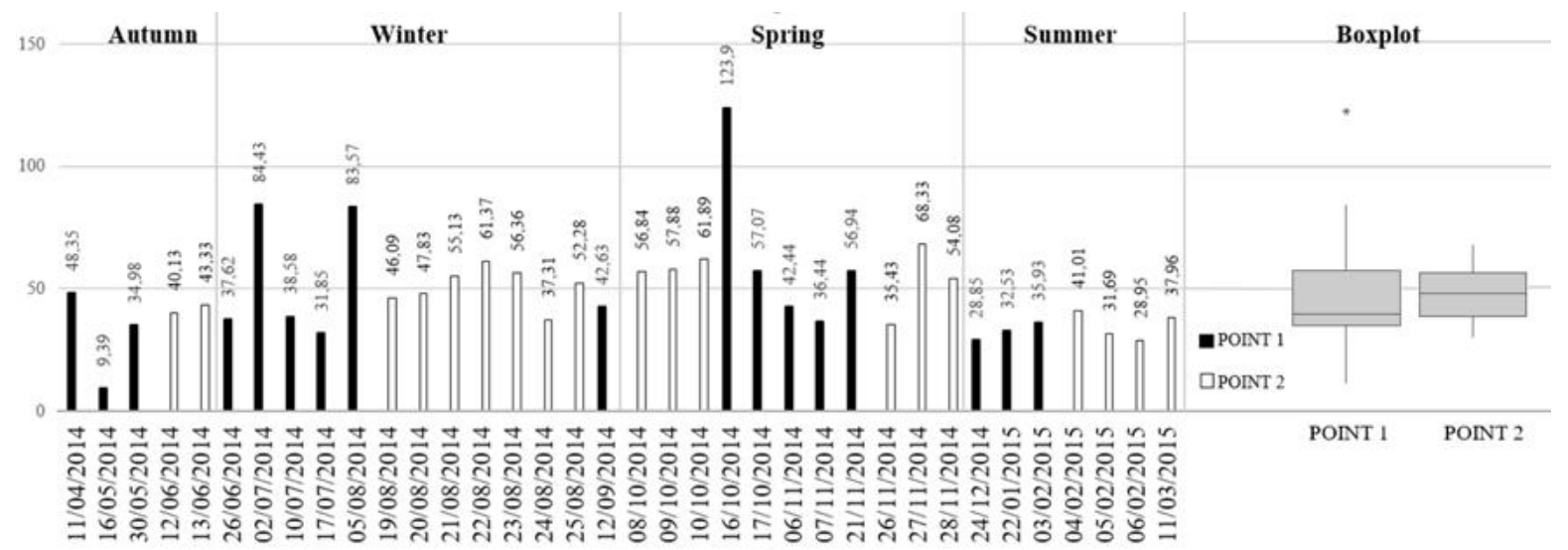

Figure 2. Concentration of $\mathrm{PM}_{10}$ data separated by location and station followed by Boxplot of concentration data. 
The samples from Point 1 presented a range of $\mathrm{PM}_{10}$ concentration of $9.4 \mu \mathrm{g} \mathrm{m}^{-3}$ occurring in the fall, and $123 \mu \mathrm{g} \mathrm{m}^{-3}$ in the spring. During the monitored period, the concentration of $\mathrm{PM}_{10}$ in samples showed abrupt changes over time. Two samples in the winter exceeded $50 \mu \mathrm{g} \mathrm{m}^{-3}$, classified according to US-EPA as "Moderate". In the spring, three samples presented concentrations higher than $50 \mu \mathrm{g} \mathrm{m}^{-3}$, two presented as "Moderate" and one as "Unhealthy for Sensitive Groups". In the summer rainy season, these limits were not exceeded, resulting in good air quality.

Point 2 samples presented a range of $\mathrm{PM}_{10}$ concentration of $29 \mu \mathrm{g} \mathrm{m}^{-3}$ in the summer season and $68 \mu \mathrm{g} \mathrm{m}^{-3}$ during spring time. The results showed a stable behavior throughout the sampling campaign, with only a slight decline in concentration in the summer. In winter, four samples exceeded $50 \mu \mathrm{g} \mathrm{m}^{-3}$. In the spring, two samples exceeded $50 \mu \mathrm{g} \mathrm{m}^{-3}$, and one of them had the highest value recorded in the whole campaign for this site, $68 \mu \mathrm{g} \mathrm{m}^{-3}$. In the summer, no sample exceeded the recommended limits.

Related to elemental concentration results, Table 1 displays the range of the values determined for the elemental concentration in the particulate matter collected in the air filters. Elements that presented values lower than their limits of detection, that is, Ag, Cd and $\mathrm{Hg}$, were not included in the calculations.

The Brazilian legislation does not foresee maximum values allowed in particulate matter for elemental concentration (Querol et al., 2001, except for lead (CETESB, 2017). Comparing the obtained values in Table 1 with the values of samples of $\mathrm{PM}_{10}$ collected in China (Song et al., 2017), for instance, the Chinese results are higher. One reason is due to poor environmental control. Comparing the same results with those from another Brazilian capital, São Paulo, there are similarities of pollution in terms of chemical elements and elemental concentrations (Albuquerque et al., 2012; Almeida et al., 2017). European elemental concentrations are below those found in this study. The report points out a tendency of reduction of pollution, due to the public policies in those countries (Leoni et al., 2018).

Table 1. Lower and upper values for elemental concentrations determined in the particulate matter collected in the air filters.

\begin{tabular}{|c|c|c|c|c|c|c|c|c|c|}
\hline \multirow{2}{*}{$\frac{\text { Elem. }}{\mathrm{Ag}}$} & \multicolumn{2}{|c|}{ Point $1\left(\mathrm{pg} \mathrm{m}^{-3}\right)$} & \multicolumn{2}{|c|}{ Point $2\left(\mathrm{pg} \mathrm{m}^{-3}\right)$} & \multirow{2}{*}{$\begin{array}{c}\text { Elem. } \\
\mathrm{Na}\end{array}$} & \multicolumn{2}{|c|}{ Point $1\left(\mathrm{pg} \mathrm{m}^{-3}\right)$} & \multicolumn{2}{|c|}{ Point $2\left(\mathrm{pg} \mathrm{m}^{-3}\right)$} \\
\hline & & $\mathrm{DL}$ & & $\mathrm{DL}$ & & 43676 & 1291138 & 91861 & - 358425 \\
\hline As & 23.3 & $\begin{array}{ll}- & 79.5\end{array}$ & 23.2 & 39.3 & $\mathrm{Nd}$ & 13.7 & 323 & 59 & 88.8 \\
\hline $\mathrm{Au}$ & 0.1 & 0.4 & 0.1 & 0.2 & $\mathrm{Rb}$ & 20 & 408 & 41.8 & 97.4 \\
\hline Ва & 24613 & - 722536 & 77343 & 209459 & $\mathrm{Sb}$ & 2.8 & 3212 & 10.5 & 53 \\
\hline $\mathrm{Br}$ & 4.1 & 292 & 11.7 & 53.2 & Sc & 0.6 & 13.0 & 0.9 & 3.8 \\
\hline $\mathrm{Ca}$ & 10067 & - 305862 & 29437 & 83641 & Se & 53.5 & 92.6 & 29.8 & 726 \\
\hline Cd & & $\mathrm{DL}$ & & $\mathrm{DL}$ & Sm & 1.1 & 51 & 1.2 & 17.1 \\
\hline $\mathrm{Ce}$ & 11.3 & $-\quad 642$ & 12.7 & $-\quad 227$ & $\mathrm{Sr}$ & 928 & 28890 & 2851 & 8132 \\
\hline Co & 0.4 & 13.7 & 0.9 & 3.9 & Тa & 0.2 & 19.1 & 0.4 & 5.7 \\
\hline $\mathrm{Cr}$ & 37.1 & 977 & 58.8 & 254 & $\mathrm{~Tb}$ & 0.3 & 435 & 0.5 & 5.1 \\
\hline Cs & 1.6 & 7.9 & 1.5 & 3.3 & Th & 1.7 & 86.1 & 4.1 & 30.2 \\
\hline $\mathrm{Eu}$ & 0.8 & 80.3 & 1 & 11.5 & $\mathrm{U}$ & 1.7 & 33.5 & 7.5 & 12.5 \\
\hline $\mathrm{Fe}$ & 1846 & 85157 & 3815 & 23304 & $\mathrm{~W}$ & 3754 & 4150 & 1584 & 4214 \\
\hline $\mathrm{Hf}$ & 12.7 & $-\quad 229$ & 12.1 & 92.6 & $\mathrm{Yb}$ & 5.2 & 94.7 & 3.4 & 33.6 \\
\hline $\mathrm{Hg}$ & & $\mathrm{DL}$ & & $\mathrm{DL}$ & Zn & 20039 & 569939 & 57009 & - 167672 \\
\hline $\mathrm{K}$ & 30019 & - 469573 & 61232 & - 307734 & $\mathrm{Zr}$ & 554 & 2068 & 1649 & 2483 \\
\hline $\mathrm{La}$ & 6.7 & 338 & 6.7 & 118 & & & & & \\
\hline
\end{tabular}

$<$ DL, lower than the value corresponding to the limit of detection. 


\subsection{Statistical analysis}

PCA was used after normalization for statistical analysis. The variables used were the chemical elements of the samples of the $\mathrm{PM}_{10}$ and their elemental concentrations. As the variables were higher than the number of samples, it was necessary to reduce the number of variables, according to Mingoti (Mingoti, 2005). This was based on the concentration frequency of the variables, that is, concentration values with smaller occurrences in the samples were excluded from the analysis.

The PCA and the Varimax rotation were used for better data interpretation, providing the factors that contribute to the sample matrix. The results of PCA were highlighted that showed greater relevance among the factors of each variable (Mingoti, 2005).

\subsubsection{Site: Point 1}

The software Minitab reduced the original variables of sampling site Point 1 according to Mingoti (Mingoti, 2005), obtaining two factors, shown in Table 2. The Kaiser criterion (Rebelo et al., 2015; Stobinski et al., 2014) was taken into account, using values of the eigenvalues higher than 1 . For this analysis, sixteen variables were used (Ba, Br, Ca, Ce, Co, Cr, Fe, Hf, K, $\mathrm{La}, \mathrm{Na}, \mathrm{Sb}, \mathrm{Sc}, \mathrm{Tb}$, Th and Zn) of the thirty-three obtained.

Table 2. Results of PCA after rotation VARIMAX at Point 1.

\begin{tabular}{ccc}
\hline Variable & Factor 1 & Factor 2 \\
\hline $\mathrm{Ba}$ & 0.955 & - \\
$\mathrm{Br}$ & 0.915 & - \\
$\mathrm{Ca}$ & 0.932 & - \\
$\mathrm{Ce}$ & - & 0.724 \\
$\mathrm{Co}$ & 0.950 & - \\
$\mathrm{Cr}$ & 0.887 & - \\
$\mathrm{Fe}$ & 0.948 & - \\
$\mathrm{Hf}$ & 0.753 & - \\
$\mathrm{K}$ & 0.936 & - \\
$\mathrm{La}$ & - & 0.696 \\
$\mathrm{Na}$ & 0.858 & - \\
$\mathrm{Sb}$ & 0.832 & - \\
$\mathrm{Sc}$ & 0.938 & - \\
$\mathrm{Tb}$ & - & - \\
$\mathrm{Th}$ & 0.691 & - \\
$\mathrm{Zn}$ & 0.953 & - \\
\hline Eigenvalues & 13.130 & 1.068 \\
Total variance (\%) & 70.2 & 18.5 \\
Cumulative variance (\%) & 70.2 & 88.7 \\
\hline
\end{tabular}

It was verified that the accumulated variance is $88.7 \%$ of the data. Factor 1 explained $70.2 \%$ of the total variation, where the elements $\mathrm{Ba}, \mathrm{Br}, \mathrm{Ca}, \mathrm{Co}, \mathrm{Cr}, \mathrm{Fe}, \mathrm{Hf}, \mathrm{Na}, \mathrm{Sb}, \mathrm{Sc}$, Th and $\mathrm{Zn}$ contributed to this first factor. From the characterization of the factor loadings, the main contributors can be identified. These elements indicate a strong influence of geogenic origin (Destefan and Holanda, 2011; Moreno et al., 2017; Noce et al., 1997), although it is difficult to differentiate its origin due to the processes of transport and resuspension of the soil. The elements $\mathrm{Ba}, \mathrm{Na}$ and $\mathrm{Zn}$ strengthen even more this origin due to their elemental concentrations, averaging $165 \mathrm{ng} \mathrm{m}^{-3}$, $328 \mathrm{ng} \mathrm{m}^{-3}$ and $128 \mathrm{ng} \mathrm{m}^{-3}$, respectively. The elements in Factor 1 may come mainly from streets that are covered by paving stones and close to an ecological reserve.

Factor 2 explains $18.5 \%$ of the total variation, where the elements $\mathrm{Ce}$ and $\mathrm{La}$ are the main contributors for this factor. These elements indicate, according to the PM speciation profiles repository of air pollution sources of the United States Environmental Protection Agency - 
Speciate (USEPA, 2015), influence from fuel combustion (gasoline, oil and diesel) of automotive supplies and paving stones of the municipal road in front of the sampled site (Silva et al., 2009; Xue et al., 2006). The elements La and Ce have average concentrations of $0.06 \mathrm{ng}$ $\mathrm{m}^{-3}$ and $0.13 \mathrm{ng} \mathrm{m}^{-3}$, respectively. There are no specific studies of isotopic ratios of rare earths present in PM in Brazil. In addition to these influences, the burning of organic material and construction can also contribute to the presence of these elements. The relationship between La and Ce of the analyzed samples showed an increase of approximately $10 \%$ in comparison with the crustal source of Belo Horizonte (Noce et al., 1997).

\subsubsection{Site: Point 2}

The original variables of the samplings carried out in Point 2 were reduced, according to Mingoti (Mingoti, 2005), based upon the concentration frequency of the variables. The Kaiser criterion (Rebelo et al., 2015; Stobinski et al., 2014) was also followed. Three factors were obtained as shown in Table 3, with a cumulative variance of $84.9 \%$ of the variability in the data. For this analysis, 17 variables were used (Ba, Ca, Ce, Co, Cr, Fe, Hf, K, La, Na, Sb, Sc, Sm, $\mathrm{Ta}, \mathrm{Tb}, \mathrm{Th}, \mathrm{Zn}$ ) from the thirty-three obtained, due to the removal of variables that were not found elementary concentrations representative for the calculation of PCA.

Table 3. Results of the PCA after VARIMAX rotation at Point 2.

\begin{tabular}{cccc}
\hline Variable & Factor $\mathbf{1}$ & Factor $\mathbf{2}$ & Factor 3 \\
\hline $\mathrm{Ba}$ & 0.960 & - & - \\
$\mathrm{Ca}$ & 0.865 & - & - \\
$\mathrm{Ce}$ & - & 0.962 & - \\
$\mathrm{Co}$ & 0.871 & - & - \\
$\mathrm{Cr}$ & 0.701 & 0.700 & - \\
$\mathrm{Fe}$ & 0.867 & - & - \\
$\mathrm{Hf}$ & 0.719 & - & - \\
$\mathrm{K}$ & - & - & -0.653 \\
$\mathrm{La}$ & - & 0.953 & - \\
$\mathrm{Na}$ & 0.936 & - & - \\
$\mathrm{Sb}$ & 0.628 & - & - \\
$\mathrm{Sc}$ & 0.881 & - & - \\
$\mathrm{Sm}$ & - & - & - \\
$\mathrm{Ta}$ & - & - & 0.620 \\
$\mathrm{~Tb}$ & - & 0.967 & - \\
$\mathrm{Th}$ & - & 0.965 & - \\
$\mathrm{Zn}$ & 0.962 & - & - \\
\hline Eigenvalues & 9.883 & 3.280 & 1.269 \\
Total variance (\%) & 43.5 & 33.3 & 8.1 \\
Cumulative variance (\%) & 43.5 & 76.8 & 84.9 \\
\hline
\end{tabular}

Factor 1 explains $43.5 \%$ of the total variation, where 10 elements contributed to this factor (Ba, Ca, Co, Cr, Fe, Hf, Na, Sb, Sc and Zn). Through the factorial loads, the elements of this factor indicate a strong influence of geogenic origin (Noce et al., 1997).

Factor 2 explains 33.3\% of the total variation, where $\mathrm{Th}$, Tb, Ce and $\mathrm{La}$ contributed to this factor. Through factor loads, there is a strong influence on fuel combustion, similar to the second factor at Point 1 (Silva et al., 2009; Xue et al., 2006), which identified sources from automotive fuel burning, burning of organic material (leaves of trees), buildings, and coal combustion (wood burning) (Someshwar and Jain, 2003; USEPA, 2015).

Factor 3 explains $8.1 \%$ of the total variation, where Ta and $\mathrm{K}$ contributed to this factor. Factorial loads show the influence of oil combustion, cigarettes, fertilizers, Portland cement, diesel and furnace, due to the maintenance of the wooded sites at the university and the buildings in the vicinity of the sampling site (Guillén et al., 2017; USEPA, 2017). 


\section{CONCLUSION}

The first sampling site (Point 1 ) is near buildings and streets with a constant traffic of vehicles. The second sampling site (Point 2) is near an avenue with intense and constant traffic of vehicles (cars, buses and trucks). Concerning the concentration of airborne particulate matter, $\mathrm{PM}_{10}$, Point 2 presented higher range of values than Point 1 . The highest value, in spring time, was considered "Unhealthy for Sensitive Groups" according to US-EPA. These results point out that this site near of the avenue presents more health risks. In general, the values were $40 \%$ higher than those recommended by legislation. In the summer rainy season, no sample exceeded the recommended limits.

The analysis of the elemental composition of $\mathrm{PM}_{10}$, resulted in the determination of thirtythree elements. This information was fundamental for the verification of possible $\mathrm{PM}_{10}$ emitters present in the sampling sites by means of the statistical technique of multivariate analysis, using the main component method.

Two factors were identified for the first sampled site and three factors for the second site. It was observed that in both locations the air quality is influenced by vehicular emissions, though more strongly at Point 2. At Point 1, the influence of the dust from the soil was confirmed. At this point, the lower contribution of the vehicular sources was expected due to its central position in relation to the avenues that surround the site. However, the results suggest that the pollutants are transported from the streets in direction of the study area.

This study suggests that air quality monitoring should be conducted periodically to identify and alert the population of the health risks related to air pollution. This monitoring should also provide data for a better statistic for the study of local air quality. Therefore, the methodologies used in this study to determine airborne particulate matter concentration, the chemical composition and a statistical tool for multivariate analysis, are useful in $\mathrm{PM}_{10}$ research.

\section{ACKNOWLEDGEMENTS}

This research project was supported by the following Brazilian institutions: the Nuclear Technology Development Center (CDTN), the Brazilian Nuclear Energy Commission (CNEN), Coordination of Improvement of Higher Level Personnel (CAPES), the Research Support Foundation of the State of Minas Gerais (FAPEMIG), and the Brazilian Council for Scientific and Technological Development (CNPq).

\section{REFERENCES}

ADISSI, P. J.; PINHEIRO, F. A.; CARDOSO, R. S. Gestão ambiental de unidades produtivas. Rio de Janeiro: Elsevier, 2013.

ALBUQUERQUE, T. T. De A.; ANDRADE, M. De F.; YNOUE, R. Y. Characterization of atmospheric aerosols in the city of São Paulo, Brazil: comparisons between polluted and unpolluted periods. Environmental Monitoring and Assessment, v. 184, n. 2, p. 969984, 2012. https://doi.org/10.1007/s10661-011-2013-y

ALMEIDA, T. S.; SANT’ANA, M. O.; CRUZ, J. M.; TORMEN, L.; BASCUÑAN, V. L. A. F.; AZEVEDO, P. A. et al. Characterisation and source identification of the total airborne particulate matter collected in an urban area of Aracaju, Northeast, Brazil. Environmental Pollution, v. 226, p. 444-451, 2017. https://doi.org/10.1016/j.envpol.2017.04.018

BELO HORIZONTE. Prefeitura. Qualidade do ar. 2016. Available at: www.portalpbh.pbh.gov.br Access: 19 May 2016. 
BRASIL, J. L.; VAGHETTI, J. C. P.; ROYER, B.; SANTOS JR., A. A. Dos; SIMON, N. M.; PAVAN, F. A. et al. Planejamento estatístico de experimentos como uma ferramenta para otimização das condições de biossorção de Cu(II)em batelada utilizando-se casca de nozes peçã como biossorvente. Química Nova, v. 30, p. 548-553, 2007.

CALIJURI, M. C.; CUNHA, D. G. F. Engenharia ambiental: conceitos, tecnologia e gestão. São Paulo: Elsevier, 2013.

COMPANHIA AMBIENTAL DO ESTADO DE SÃO PAULO - CETESB. Qualidade do ar no Estado de São Paulo. 2015. Available at: http://cetesb.sp.gov.br/ar/wpcontent/uploads/sites/28/2013/12/RQAR-2015.pdf Access: 2015.

COMPANHIA AMBIENTAL DO ESTADO DE SÃO PAULO - CETESB. Padrões de Qualidade do Ar. 2017. Available at: http://cetesb.sp.gov.br/ar/padroes-de-qualidade-doar/ Access: 17 May 2017.

CONSELHO NACIONAL DO MEIO AMBIENTE. Resolução nº 003 de 28 de junho de 1990. Diário Oficial [da] União, 28 Ago. 1990, Seção I, p. 15.937-15.939.

DESTEFAN, A. Z.; HOLANDA, J. N. F. Utilização do planejamento experimental em rede simplex no estudo de resíduo de rocha ornamental como filler para obtenção de máxima compacidade. Cerâmica, v. 57, p. 491-498, 2011.

ELBAYOUMI, M.; RAMLI, N. A.; YUSOF, N. F. F. M.; YAHAYA, A. S. BIN; MADHOUN, W. AL; UL-SAUFIE, A. Z. Multivariate methods for indoor PM10 and PM2.5 modelling in naturally ventilated schools buildings. Atmospheric Environment, v. 94, p. 11-21, 2014.

ENERGÉTICA INDÚSTRIA E COMÉRCIO LTDA. Manual de operação: amostrador de grande volume (AGV) para partículas de até 10 $\mu \mathrm{m}\left(\mathrm{MP}_{10}\right)$. Rio de Janeiro, 2012.Available at: $\quad$ www.energetica.ind.br/wp/env1/wp-content/uploads/2016/01/env1_manualmp10_rev_11.pdf Access: July 2017.

FUNDAÇÃO ESTADUAL DO MEIO AMBIENTE (MG) - FEAM. Monitoramento. 2017. Available at: www.feam.br/monitoramento Access: 2017.

GUILLÉN, J.; MUÑOZ, G.; BAEZA, A.; SALAS, A.; MOCANU, N. Attempt to reduce ${ }^{239} \mathrm{Pu}$ and ${ }^{241} \mathrm{Am}$ uptake by wheat plantlets by application of inorganic fertilizers. Journal of Radioanalytical and Nuclear Chemistry, v. 311, p. 991-997, 2017. https://doi.org/10.1007/s10967-016-4894-2

HAIR, J. F.; BLACK, W. C.; BABIN, B. J.; ANDERSON, R. E.; TATHAM, R. L. Análise Multivariada. 6. ed. Rio de Janeiro: Bookman, 2009.

HEALTH EFFECT INSTITUTE - HEI. Understanding the health effects of components of the particulate matter mix: progress and next steps. Insights from HEI's research programs. Boston, 2002.

INSTITUTO BRASILEIRO DE GEOGRAFIA E ESTATÍSTICA - IBGE. IBGE Cidades. 2016. Available at: http://cidades.ibge.gov.br/painel/painel.php?lang=\&codmun=310620 Access: 8 May 2017.

JACOMINO, V. M. F.; BARRETO, A. A.; TAVARES, F. V. F.; PEIXOTO, C. M.; RODRIGUES, P. C. H. Avaliação da qualidade do ar em um polo produtor de ferro-gusa. Engenharia Sanitária e Ambiental, v.14 n. 4, p. 511-520, 2009. 
KAPPOS, A. D.; BRUCKMANN, P.; EIKMANNC, T.; ENGLERTD, N.; HEINRICHE, U.; HÖPPE, P. et al. Health effects of particles in ambient air. International Journal of Hygiene and Environmental Health, v. 207, p. 399-407, 2004. https://doi.org/10.1078/1438-4639-00306

LEONI, C.; POKORNA, P.; HOVORKA, J.; MASIOL, M.; TOPINKA, J.; ZHAO, Y. et al. Source apportionment of aerosol particles at a European air pollution hot spot using particle number size distributions and chemical composition. Environmental Pollution, v. 234, p. 145-154, 2018. https://doi.org/10.1016/j.envpol.2017.10.097

MEGIDO, L.; NEGRAL, L.; CASTRILLÓN, L.; FERNÁNDEZ-NAVA, Y.; SUÁREZ-PEÑA, B.; MARAÑÓN, E. Impact of secondary inorganic aerosol and road traffic at a suburban air quality monitoring station. Journal of Environmental Management, v. 189, p. 3645, 2017. https://doi.org/10.1016/j.jenvman.2016.12.032

MENEZES, M. Â. D. B. C.; JACIMOVIC, R. Optimised k0-instrumental neutron activation method using the TRIGA MARK I IPR-R1 reactor at CDTN/CNEN, Belo Horizonte, Brazil. Nuclear Instruments and Methods Physics Research, v. 564, p. 707-715, 2006. https://doi.org/10.1016/j.nima.2006.04.013

MINGOTI, S. A. Análise de dados através de métodos de estatística multivariada: uma abordagem aplicada. Belo Horizonte: Editora UFMG, 2005.

MORENO, J.; FATELA, F.; LEORRI, E.; MORENO, F.; FREITAS, M. C.; VALENTE, T. et al. Bromine soil/sediment enrichment in tidal salt marshes as a potential indicator of climate changes driven by solar activity: New insights from W coast Portuguese estuaries. Science of the Total Environment, v. 580, p. 324-338, 2017. https://doi.org/10.1016/j.scitotenv.2016.11.130

NAGENDRA, S. M. S.; KHARE, M. Line source emission modelling. Atmospheric Environment, v. 36, p. 2083-2098, 2002. https://doi.org/10.1016/S1352-2310(02)00177-2

NOCE, C. M.; TEIXEIRA, W.; MACHADO, N. Geoquímica dos gnaisses ttgs e granitóides neoarqueanos do complexo Belo Horizonte, quadrilátero ferrífero, Minas Gerais. Revista Brasileira de Geociências, v. 27, p. 25-32, 1997.

PÖYKIÖ, R.; PERÄMÄKI, P.; RÖNKKÖMÄKI, H. The homogeneity of heavy metal deposition on glass fibre filters collected using a high-volume sampler in the vicinity of an opencast chrome mine complex at Kemi, Northern Finland. Analytical and Bioanalytical Chemistry, v. 375, p. 476-481, 2003. https://doi.org/10.1007/s00216-002-1704-1

REBELO, M.; SILVA, E. F. Da; ROCHA, F. Characterization of Portuguese Thermo-mineral waters to be applied in peloids maturation. Environmental Earth Sciences, v. 73, p. 2843-2862, 2015. https://doi.org/10.1007/s12665-014-3670-2

SÁNCHES-RODAS, D.; ALSIOUFI, L.; LA CAMPA, A. M. S. De; GONZÁLEZCASTANEDO, Y. Antimony speciation as geochemical tracer for anthropogenic emissions of atmospheric particulate matter. Journal of Hazardous Materials, v. 324, p. 213-220, 2017. https://doi.org/10.1016/j.jhazmat.2016.10.051

SHARMA, P.; KHARE, M. Modelling of vehicular exhausts - a review. Transportation Research, v. 6, p. 179-198, 2001. https://doi.org/10.1016/S1361-9209(00)00022-5

SILVA, R. A.; VIANA, M. M.; MOHALLEM, N. D. S. Caracterização textural, morfológica e estrutural de catalisadores automotivos novos e usados. Cerâmica, v. 55, p. 170-176, 2009. https://doi.org/10.1590/S0366-69132009000200008 
SOMESHWAR, A.; JAIN, A. K. Compilation of 'air toxic' and total hydrocarbon emissions data for sources at kraft, sulfite and non-chemical pulp mills - An Update. ResearchGate, n. 858, 2003.

SONG, C.; WU, L.; XIE, Y.; HE, J.; CHEN, X.; WANG, T. et al. Air pollution in China: Status and spatiotemporal variations. Environmental Pollution, v. 227, p. 334-347, 2017. https://doi.org/10.1016/j.envpol.2017.04.075

STOBINSKI, M.; SZARLOWICZ, K.; RECZYNSKI, W.; KUBICA, B. The evaluation of 137Cs radioactivities in soils taken from the Babia Góra National Park. Journal of Radioanalytical and Nuclear Chemistry, v. 299, p. 631-635, 2014. https://doi.org/10.1007/s10967-013-2809-z

TAVARES, F. V. F.; ARDISSON, P. C. H.; RODRIGUES, P. C. H.; BRITO, W.; MACEDO, W. A. A.; JACOMINO, V. M. F. Characterization of iron in airborne particulate matter. Hyperfine Interactions, v. 224, p. 109-119, 2014. http://dx.doi.org/10.1007/978-94-0076482-8_13

UNIVERSIDADE FEDERAL DE MINAS GERAIS - UFMG. Diretrizes gerais para questões de trânsito, transporte e estacionamento no Campus da Pampulha Documento para discussão com a comunidade. 2010. Available at: https://www.ufmg.br/online/arquivos/anexos/Diretrizes_Gerais_para_as_questoes_de_transi to_transporte_e_estacionamentos_no_Campus_da_Pampulha.pdf. Access: 1 Oct. 2017.

UNITED STATES. Environmental Protect Agency - USEPA. Speciate. Air Emissions Modeling. 2015. Available at: https://www.epa.gov/air-emissions-modeling/speciateversion-45-through-32. Access: 1 Oct. 2017.

UNITED STATES. Environmental Protect Agency - USEPA. Sampling of ambient air for total suspended particulate matter (SPM) and PM10 using high volume (HV) sampler (EPA/625/R-96/010a). 1999. Available at: https://www3.epa.gov/ttnamti1/files/ambient/inorganic/mthd-2-1.pdf. Access: 1 Oct. 2017.

UNITED STATES. Environmental Protect Agency - USEPA. AQI - Air Quality Index - A Guide to Air Quality and Your Health (No. EPA-456/F-14-002). 2014. Available at: https://www3.epa.gov/airnow/aqi_brochure_02_14.pdf. Access: 1 Oct. 2017.

WORLD HEALTH ORGANIZATION - WHO Air quality guidelines for particulate matter, ozone, nitrogen dioxide and sulfur dioxide - Global Update 2005 - Summary of Risk assessment. $2006 . \quad$ Available at: http://apps.who.int/iris/bitstream/10665/69477/1/WHO_SDE_PHE_OEH_06.02_eng.pdf Access: 1 Oct. 2017.

XUE, M.; CHITRAKAR, R.; SAKANE, K.; HIROTSU, T.; OOI, K.; YOSHIMURA, Y. et al. Preparation of cerium-loaded Y-zeolites for removal of organic sulfur compounds from hydrodesulfurizated gasoline and diesel oil. Journal of Colloid and Interface Science, v. 298, p. 535-542, 2006. https://doi.org/10.1016/j.jcis.2005.12.051 


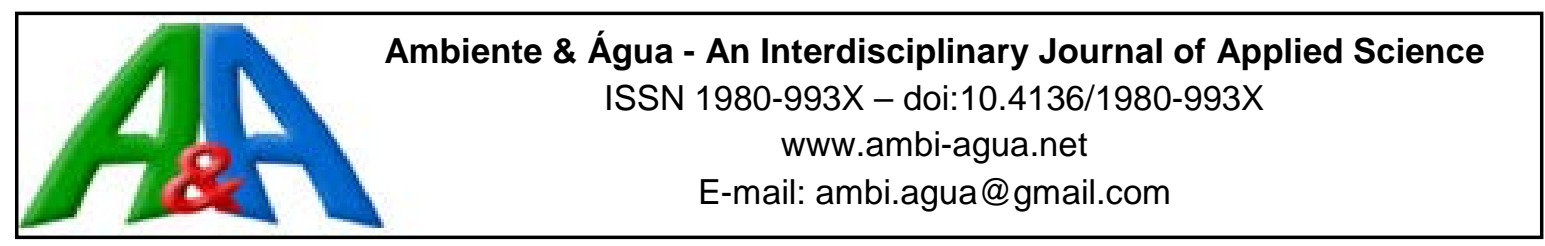

\title{
Metrological performance of single-jet water meters over time
}

\author{
ARTICLES doi:10.4136/ambi-agua.2205 \\ Received: 28 Oct. 2017; Accepted: 20 Aug. 2018 \\ Carmen Virginia Palau'; Juan Manzano'; Iban Balbastre Peralta1; \\ Benito Moreira de Azevedo²; Guilherme Vieira do Bomfim²* \\ ${ }^{1}$ Universitat Politècnica de València (UPV), Valencia, Spain \\ Departamento de Ingeniería Rural y Agroalimentaria (DIRA). E-mail: virpaes@agf.upv.es, \\ juamanju@agf.upv.es, ibbalpe@agf.upv.es \\ ${ }^{2}$ Universidade Federal do Ceará (UFC), Fortaleza, CE, Brasil \\ Departamento de Engenharia Agrícola (DENA). E-mail: benitoazevedo@hotmail.com, \\ guile2007@gmail.com \\ ${ }^{*}$ Corresponding author
}

\begin{abstract}
To maintain quality measurement of water consumption, it is necessary to know the metrology of single-jet water meters over time. Knowing the accuracy of these instruments over time allows establishing a metrological operation period for different flow rates. This will aid water companies to optimize management and reduce economic losses due to unaccounted water consumption. This study analyzed the influence of time on the measurement error of single-jet water meters to evaluate the deterioration of the equipment and, with that, launch the metrological operation period. According to standards 8316 and 4064 of the International Organization for Standardization (ISO), 808 meters of metrological Class B were evaluated in six water supplies, with age ranges of 3.7 to 16.4 years of use. The measurement error was estimated by comparing the volume measured in a calibrated tank with the volume registered by the meters at flow rates of 30,120, 750 and 1,500 $\mathrm{L} \mathrm{h}^{-1}$. The metrological operation period of the meters was obtained for each flow rate by the relation between error of measurement and time of use (simple linear regression). According to the results, the majority of the equipment presents increasing under-registration errors over time, more pronounced at low flow rates and with less favorable operating conditions. The metrological operation period for flow rates of 30, 120, 750 and 1,500 L h $\mathrm{h}^{-1}$ is estimated at approximately 3, 8, 14 and 13 years. This operation period combined with consumption patterns of users will establish the best time to replace the meters.
\end{abstract}

Keywords: hydrometry, measurement error, water consumption.

\section{Desempenho metrológico de hidrômetros unijato com o tempo de uso}

\section{RESUMO}

Para manter a qualidade de medição do consumo de água, é necessário conhecer a metrologia de hidrômetros unijato ao longo do tempo. Conhecer a metrologia desses instrumentos com o tempo permite estabelecer um período de operação metrológica para diferentes vazões. Isso ajudará as empresas de água a otimizar a gestão e a reduzir as perdas econômicas devido ao consumo do volume de água não contabilizado. Neste estudo, a 
influência do fator tempo sobre o erro de medição de hidrômetros unijato foi analisada com o objetivo de estimar sua deterioração e, com isso, o período de operação metrológica. Conforme as normas 8316 e 4064 da Organização Internacional de Normalização (ISO), foram avaliados em seis abastecimentos 808 hidrômetros de classe metrológica $B$, com uma faixa de idade de 3,7 a 16,4 anos de uso. O erro de medição foi calculado pela comparação entre o volume de um depósito calibrado e o volume medido pelos hidrômetros, nas vazões de 30, 120, 750 e $1.500 \mathrm{~L} \mathrm{~h}^{-1}$. O período de operação metrológica dos medidores foi estimado para cada vazão, por meio da relação entre erro de medição e tempo de uso (regressão linear simples). De acordo com os resultados, a maioria dos hidrômetros apresenta erros crescentes de submedição com o tempo, sendo mais pronunciados nas vazões reduzidas e nas condições de funcionamento menos favoráveis. O período de operação metrológica para as vazões de 30, 120, 750 e $1.500 \mathrm{~L} \mathrm{~h}^{-1}$ é estimado em aproximadamente 3, 8, 14 y 13 anos. Este período de operação, combinado com os padrões de consumo dos usuários, estabelecerá o melhor momento para substituir os hidrômetros.

Palavras-chave: consumo de água, erro de medição, hidrometria.

\section{INTRODUCTION}

Single-jet water meters are the most widely used velocity meters for quantifying domestic water consumption (Szilveszter et al., 2017), mainly due to their low cost and high reliability (Arregui et al., 2007). This technology is used in residential areas (Arregui et al., 2016) and in small areas of pressurized irrigation systems (Daneshnia et al., 2015).

These water meters are composed of a totalizer incorporated by mechanical or magnetic coupling to a turbine inside a measuring chamber. The incidence of a tangential water jet on the turbine generates the rotation of this element. The rotation speed is directly proportional to the flow rate and to the volume registered (Arregui et al., 2007).

Over time, like any mechanical instrument, these water meters present a natural deterioration of their mobile elements that can cause significant measurement errors. The problem is more serious when this wear is accelerated by external factors, such as inadequate mounting position, reduced pressure in the network (Arregui et al., 2007), poor water quality (Buck et al., 2012), water freezing (Cichoń and Królikowska, 2016), on-site leakage (Couvelis and van Zyl, 2015), storage tanks (Mutikanga et al., 2011), partial blockage of the inlet strainer, water consumption patterns (Arregui et al., 2005), different manufacturers (Shields et al., 2012), and intermittently operated pipe networks (Walter et al., 2018).

Studies show that the degradation of single-jet meters over time, especially when associated with low flows rates, causes increasing errors of under-registration (Criminisi et al., 2009; Mutikanga et al., 2011, Puleo et al., 2014). The magnitude of these errors varies according to the manufacturer and materials used, the quality of water and the installation conditions of each water meter.

The lack of knowledge of the metrological evolution of these instruments over time can produce economic losses due to unregistered consumption. This study therefore evaluated this deterioration over time. This is fundamental to estimate the metrological operational period to achieve adequate water meter management.

\section{MATERIALS AND METHODS}

The tests were carried out in the laboratory of the ITA (Sustainable Urban Water Management), located in the Universitat Politècnica de València, Valencia, Spain.

The metrological behavior of the single-jet water meters was analyzed by the method of 
collecting liquid in a volumetric tank, according to ISO 8316 (1987). To meet the requirements of this standard, a test bench with two calibrated tanks and three independent flow lines was installed in the laboratory (Figure 1A).

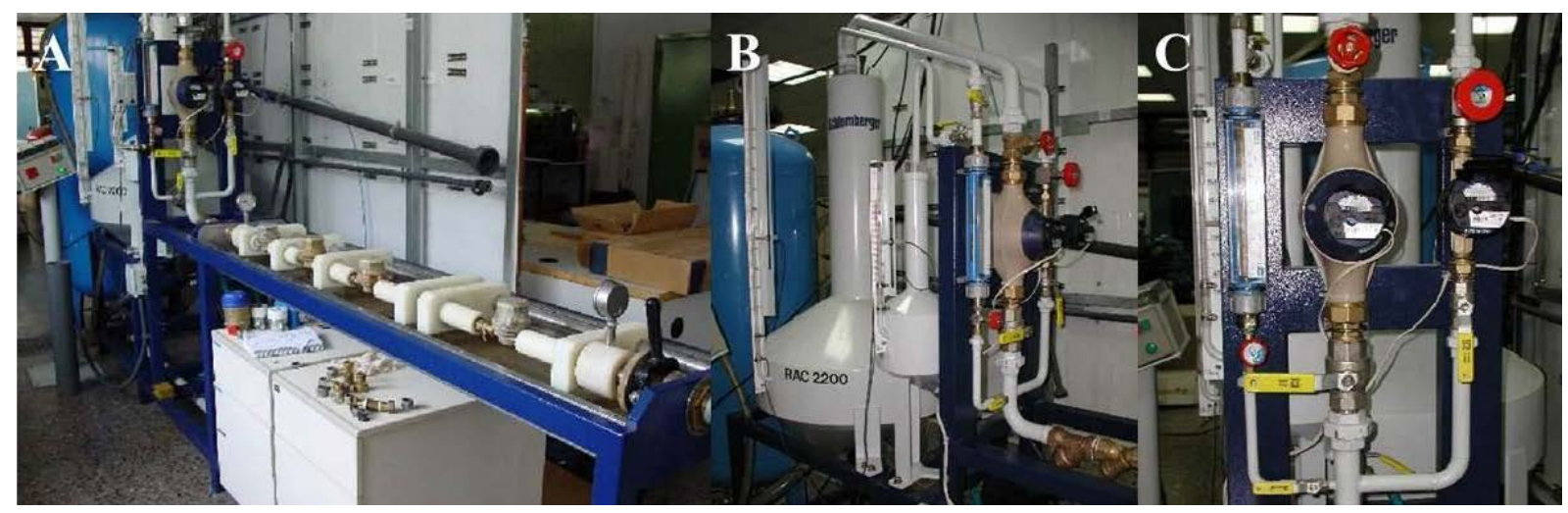

Figure 1. Test bench (A), calibrated volumetric tanks (B) and accurate volumetric water meters and rotameter $(\mathrm{C})$.

The calibrated tanks of 10 and $200 \mathrm{~L}$ had resolutions of 0.01 and $0.2 \mathrm{~L}$, respectively, and an accuracy of $0.2 \%$ as percentage of span for both probes. Each tank contained a capacitive level switch that stopped the water flow at nominal volume and allowed measurement of the exact volume by a graduated scale (Figure 1B).

The first two flow lines had highly accurate volumetric meters with pulse emitters of $20 \mathrm{~mm}\left(0.1 \mathrm{~L}_{\text {pulse }}{ }^{-1}\right)$ and $40 \mathrm{~mm}\left(1 \mathrm{~L} \mathrm{pulse}^{-1}\right)$. The frequency of pulses was received by a converter that regulated the test flow, showing it on a digital display. The third line had a rotameter that allowed the adjustment of flow rates between 10 and $100 \mathrm{~L} \mathrm{~h}^{-1}$ (Figure 1C).

The test procedure was based on comparing the volume of the calibrated tank (actual volume) with the volume measured by the single-jet water meters (indicated volume) at four flow rates: $30 \mathrm{~L} \mathrm{~h}^{-1}$ (minimum flow rate); $120 \mathrm{~L} \mathrm{~h}^{-1}$ (transitional flow rate); $750 \mathrm{~L} \mathrm{~h}^{-1}$ (permanent flow rate); and 1,500 $\mathrm{L} \mathrm{h}^{-1}$ (maximum or overload flow rate).

In the first two flow rates, the volumes were compared using the tank of $10 \mathrm{~L}$. In the last two flow rates, the volumes were compared using the tank of $200 \mathrm{~L}$. Meters were tested by a volumetric standing-start-and-finish method (Paton, 2005). Volume readings were taken at the beginning and at the end of the test period to compare water meter measurement with calibrated volume.

The measurement error of the single-jet water meters was calculated by the volume difference in litres, by Equation 1, as referred to in ISO 4064 (2014).

Measurement error $(\%)=\left(\frac{\text { indicated volume-actual volume }}{\text { actual volume }}\right) 100$

Samples of 808 single-jet meters of metrological Class B, randomly selected by the water supply company, were tested. This metrological class must guarantee $\pm 2 \%$ accuracy for flow rates between the minimum and the transition, and $\pm 5 \%$ for flow rates between the transition and the maximum, according to withdrawal standard ISO 4064 (1993). In the current standard ISO 4064 (2014), the corresponding metrological class would be accuracy Class 2 with the same requirements.

Nine models ('a', 'b', 'c', 'd', 'e', 'f', 'g', 'h' and 'i') belonging to different manufacturers (Figure 2) were chosen for testing from six water supplies (Table 1). 


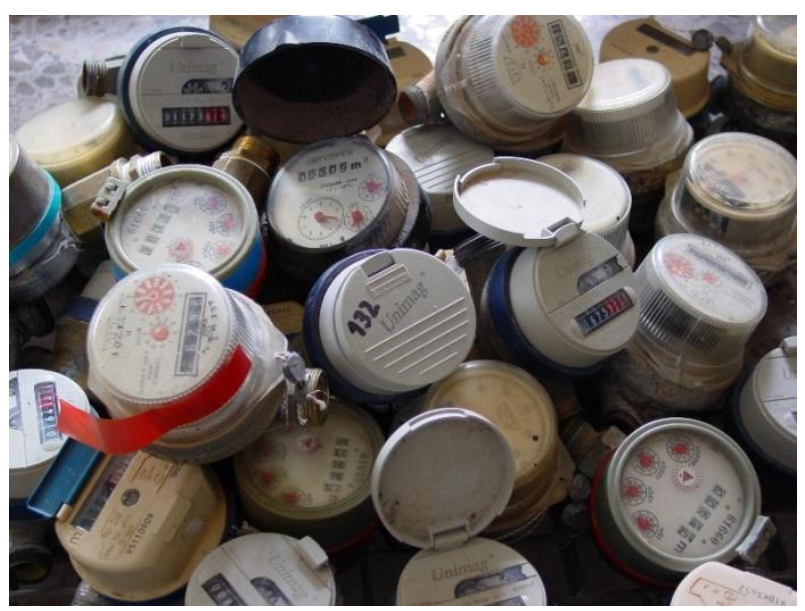

Figure 2. Sample of the evaluated single-jet meters.

Generally, water meters of analyzed supplies are similar in terms of the initial metrological class and measurement technology. The evaluated supplies have a number of users ranging from 1,500 to 200,000 homes. The differences are found in the conditions of installation and in the company management. Factors such as water quality, position of installation, topology of the dwelling or the period that the meters remain in service are variables that affect their deterioration.

Table 1. Description of the samples of single-jet water meters in service, by water supply company and by water meter model.

\begin{tabular}{|c|c|c|c|c|c|c|c|c|c|}
\hline \multirow{2}{*}{ Model } & \multicolumn{6}{|c|}{ Water supply } & \multirow{2}{*}{ Total } & \multirow{2}{*}{ NSM } & \multirow{2}{*}{ NMD } \\
\hline & 1 & 2 & 3 & 4 & 5 & 6 & & & \\
\hline a & 81 & - & 5 & 35 & - & 272 & 393 & 7 & 24 \\
\hline b & - & - & - & - & - & 66 & 66 & 2 & 1 \\
\hline c & - & 17 & - & 40 & - & 11 & 68 & 0 & 0 \\
\hline d & 3 & - & 11 & 39 & - & 3 & 56 & 0 & 0 \\
\hline $\mathrm{e}$ & 12 & - & - & 11 & - & 1 & 24 & 0 & 2 \\
\hline $\mathrm{f}$ & 34 & - & 20 & - & - & - & 54 & 16 & 13 \\
\hline g & - & 4 & - & - & 110 & 7 & 121 & 34 & 2 \\
\hline $\mathrm{h}$ & - & 1 & - & - & - & 2 & 3 & 0 & 0 \\
\hline $\mathrm{i}$ & - & - & 1 & - & - & 22 & 23 & 0 & 0 \\
\hline Total & 130 & 22 & 37 & 125 & 110 & 384 & 808 & 59 & 42 \\
\hline Subscriber & 5,500 & 750 & 4,000 & 200,000 & 4,500 & 7,500 & - & - & - \\
\hline
\end{tabular}

NSM: number of stopped water meters; NMD: number of water meters deteriorated.

Only the water meters samples in operation were evaluated in all water supplies. In this sense, the stopped and deteriorated equipment was not considered in the study. Stopped water meters were considered those with a measurement error of $-100 \%$ at all tested flow rates and deteriorated meters showed $-100 \%$ error at 30 and $120 \mathrm{~L} \mathrm{~h}^{-1}$ flow rates.

The results were analyzed by water supply and by water meter model. The discussion was based mainly on the most representative groups, which had the highest number of suitable samples. The 95\% confidence interval was estimated with samples that had a minimum of ten meters per supply to enable comparison between systems studied.

The metrological operational period of the meters was estimated for the most representative model (Model 'a'), by means of a simple linear regression graph between measurement error and time of use. This chart, using new and used water meters, was created 
by measuring the errors at regular intervals of two years. In the regression graph, the operation period was the time of use obtained with the measurement errors of $\pm 2 \%$ for the flow rates of 30 and $120 \mathrm{~L} \mathrm{~h}^{-1}$, and of $\pm 5 \%$ for the flow rates of 750 and $1,500 \mathrm{~L} \mathrm{~h}^{-1}$.

\section{RESULTS AND DISCUSSION}

\subsection{Analysis by water supply}

The average errors of the samples of each population are shown in Table 2.

In general, the water meters have more accentuated under-registration of volumes at lower flow rates, which decreases potentially when the instrument operates at higher flow rates. High under-registered errors at low flow rates can be explained by increasing friction in the rotary drive, which requires a higher flow rate to begin the movement. This friction wears moving parts and progressively reduces the accuracy of the meter (Fontanazza et al., 2013), which does not register lower than starting flow rates.

In water supply 1 , Models 'a' and ' $f$ ' show the most severe under-registration errors operating at low flow rate, in addition to the greater number of stopped and deteriorated equipment. In Models 'e' and ' $f$ ', under-registration errors greater than $-2 \%$ also occur at higher flow rates (750 and 1,500 L h'-1). In this case, the deterioration of the equipment can cause a great economic problem to the water company due to the unaccounted volume of water not registered.

In water supplies 2, 3 and 4, sample size was not considered representative of the population of instruments. Therefore, results are only valid to study the performance of water meters by model.

In water supply 5, with only Model ' $\mathrm{g}$ ' tested, the percentage of damaged water meters was high (35 instruments) and very significant. This may indicate that a defective lot of meters has been installed which can lead to significant economic losses for the company or that the sample tested is biased and not randomly selected.

Sample in water supply 6 is considered the most representative of meter population. For this reason, it is possible to carry out a detailed study of performance of water meters over time.

In general, most of the models studied have high under-registered errors, especially at low flow rates (30 and $120 \mathrm{~L} \mathrm{~h}^{-1}$ ). One parameter that may accelerate deterioration is the installation position. Inclined installation of the meter usually causes under-registered errors due to the reduction of the turbine's rotation and the rise of starting flow rate (Arregui et al., 2007). According to the mentioned authors, the turbine rotation decreases because of the inadequate position of the turbine shaft. This wrong position increases the friction and wear of the measurement zones. Furthermore, this deterioration reduces sensitivity to low flow rates and single-jet meter are not able to measure reduced flow rates.

The optimum performance of a single-jet meter is in horizontal position because the turbine shaft rests in only one point. This reduces friction and, consequently, measurement error at low flow rates are lower (Silva et al., 2012). In this position, deterioration of the turbine and the turbine shaft is smaller due to the hard and resistant materials used in manufacturing (Arregui et al., 2007).

Error curves of most representative models of the water supply 6 are shown in Figure 3. 
Table 2. Measurement errors of the single-jet water meters in service, organized by water supply.

\begin{tabular}{|c|c|c|c|c|c|c|c|c|c|}
\hline \multirow{2}{*}{ Water supply } & \multirow{2}{*}{ Model } & \multirow{2}{*}{ NMT } & \multirow{2}{*}{$\mathrm{CV}\left(\mathrm{m}^{3}\right)$} & \multicolumn{4}{|c|}{ Measurement error (\%) } & \multirow{2}{*}{ NSM } & \multirow{2}{*}{ NDM } \\
\hline & & & & $\left(30 \mathrm{~L} \mathrm{~h}^{-1}\right)$ & $\left(120 \mathrm{~L} \mathrm{~h}^{-1}\right)$ & $\left(750 \mathrm{~L} \mathrm{~h}^{-1}\right)$ & $\left(1,500 \mathrm{~L} \mathrm{~h}^{-1}\right)$ & & \\
\hline \multirow{4}{*}{1} & $\mathrm{a}$ & 70 & $1,308.4$ & $-42.7 \pm 10.1$ & $-3.0 \pm 2.7$ & $-0.9 \pm 0.9$ & $-0.4 \pm 0.8$ & 2 & 8 \\
\hline & d & 3 & $2,007.5$ & -34.5 & -5.2 & -3.1 & -2.7 & 0 & 0 \\
\hline & e & 11 & 3,396.2 & $-14.2 \pm 9.2$ & $-2.9 \pm 2.6$ & $-3.1 \pm 1.6$ & $-2.6 \pm 2.0$ & 0 & 1 \\
\hline & $\mathrm{f}$ & 26 & $3,164.6$ & $-43.0 \pm 15.2$ & $-4.9 \pm 1.7$ & $-3.9 \pm 2.2$ & $-3.1 \pm 0.8$ & 4 & 11 \\
\hline \multirow{3}{*}{2} & c & 17 & 222.9 & $-24.3 \pm 18.2$ & $-1.3 \pm 1.7$ & $-0.8 \pm 0.5$ & $-0.7 \pm 0.4$ & 0 & 0 \\
\hline & g & 3 & $1,456.7$ & -42.5 & -4.3 & 0.5 & -0.7 & 0 & 1 \\
\hline & $\mathrm{h}$ & 1 & 95.2 & -8.4 & -0.9 & 0.7 & -1.8 & 0 & 0 \\
\hline \multirow{4}{*}{3} & $\mathrm{a}$ & 4 & $1,022.3$ & -57.0 & -0.5 & 0.2 & 0.3 & 1 & 0 \\
\hline & d & 11 & $1,420.6$ & $-30.3 \pm 26.6$ & $1.3 \pm 3.2$ & $0.6 \pm 2.1$ & $2.0 \pm 2.2$ & 0 & 0 \\
\hline & $\mathrm{f}$ & 6 & $2,121.4$ & -74.2 & -7.9 & -5.5 & -6.0 & 12 & 2 \\
\hline & $\mathrm{i}$ & 1 & $1,601.6$ & -100.0 & 1.4 & -9.4 & -8.3 & 0 & 0 \\
\hline \multirow{4}{*}{4} & a & 32 & - & $-19.8 \pm 11.9$ & $0.0 \pm 0.9$ & $-0.6 \pm 0.7$ & $-0.2 \pm 0.8$ & 0 & 3 \\
\hline & c & 40 & - & $-17.3 \pm 10.1$ & $0.9 \pm 1.6$ & $1.2 \pm 1.6$ & $1.3 \pm 1.6$ & 0 & 0 \\
\hline & d & 39 & - & $-5.3 \pm 5.0$ & $-0.7 \pm 0.4$ & $-0.2 \pm 0.4$ & $0.3 \pm 0.4$ & 0 & 0 \\
\hline & e & 10 & - & $-62.5 \pm 21.5$ & $3.0 \pm 2.4$ & $4.9 \pm 2.4$ & $5.0 \pm 2.3$ & 0 & 1 \\
\hline 5 & g & 64 & 892.9 & $-14.8 \pm 6.5$ & $-2.1 \pm 1.4$ & $-0.1 \pm 0.7$ & $0.9 \pm 0.4$ & 34 & 1 \\
\hline \multirow{8}{*}{6} & $\mathrm{a}$ & 253 & 893.3 & $-52.5 \pm 5.1$ & $-6.8 \pm 1.6$ & $-1.8 \pm 0.3$ & $-1.1 \pm 0.3$ & 4 & 13 \\
\hline & $\mathrm{b}$ & 62 & $1,737.6$ & $-11.0 \pm 8.9$ & $0.0 \pm 1.3$ & $-0.2 \pm 1.7$ & $2.4 \pm 1.6$ & 2 & 1 \\
\hline & c & 11 & 352.8 & $-29.8 \pm 22.6$ & $-0.2 \pm 0.9$ & $-1.4 \pm 1.1$ & $-0.9 \pm 0.4$ & 0 & 0 \\
\hline & d & 3 & $1,110.1$ & -20.7 & -2.2 & -1.6 & -1.8 & 0 & 0 \\
\hline & e & 1 & 485.6 & -100.0 & -1.3 & 0.8 & 1.2 & 0 & 0 \\
\hline & g & 7 & 3,588.3 & -0.5 & -0.9 & -1.2 & -0.6 & 0 & 0 \\
\hline & $\mathrm{h}$ & 2 & 237.0 & -1.0 & 0.7 & -1.4 & -0.8 & 0 & 0 \\
\hline & i & 22 & $2,152.5$ & $-60.2 \pm 19.0$ & $-3.5 \pm 3.5$ & $-1.2 \pm 1.8$ & $-1.6 \pm 1.9$ & 0 & 0 \\
\hline
\end{tabular}

NMT: number of water meters tested; CV: cumulative volume; NSM: number of stopped water meters; NDM: number of water meters deteriorated. The $95 \%$ confidence interval was estimated with samples that had a minimum of ten meters per supply to enable comparison between the studied systems. 


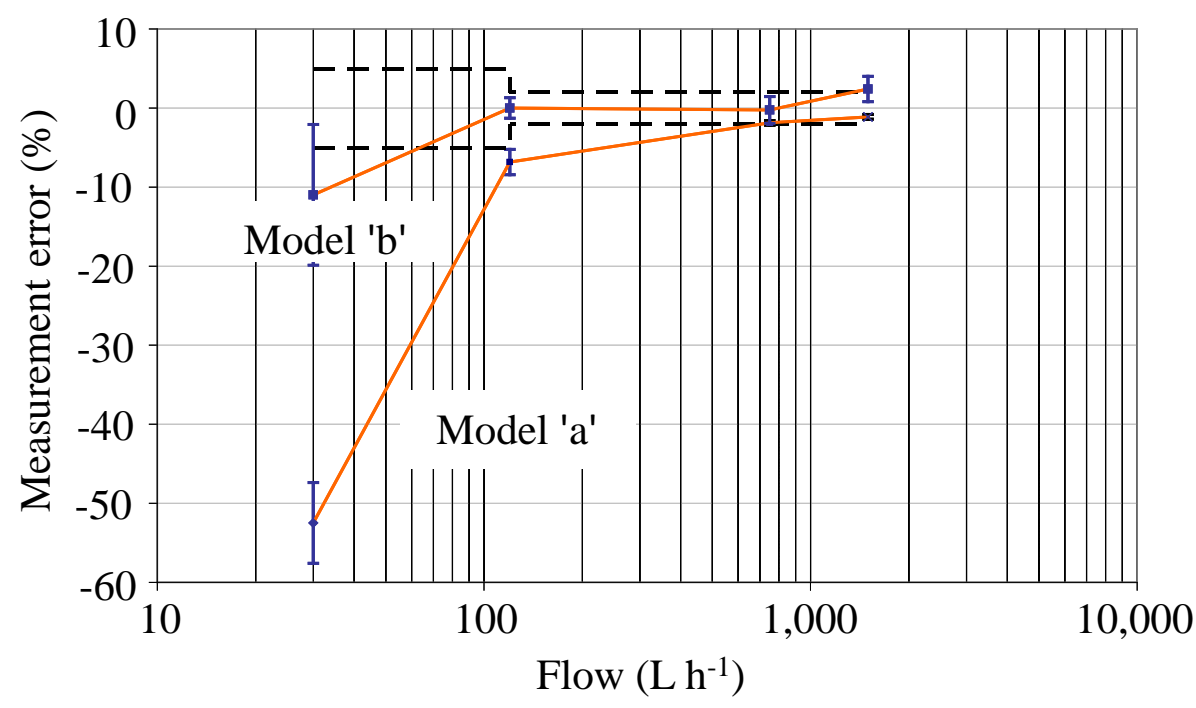

Figure 3. Error curve of the single-jet water meters Models 'a' and 'b', installed in water supply 6.

The determination of error curve in Model 'a' indicates that water meters are damaged. Therefore, average errors are outside the limits established by ISO 4064 (2014) at flow rates of 30 and $120 \mathrm{~L} \mathrm{~h}^{-1}$ (error of $\pm 5 \%$ ). In addition, a high percentage of equipment, approximately $7 \%$, were stopped or failed at 30 and $120 \mathrm{~L} \mathrm{~h}^{-1}$, or they had under-registered errors greater than $-50 \%$.

The error curve of Model 'b' indicates a better performance than Model 'a'. Also, this model shows slight over-registered errors at flow rates close to $1,500 \mathrm{~L} \mathrm{~h}^{-1}$. This can be caused by the by-pass regulation system of this model, which generates positive errors at medium and high flow rates (Silva et al., 2012). The bypass circuit is partially obstructed over time and water passes through a restricted area. This causes higher fluid velocity and turbine rotation speed increases, generating over-registration measures. According to Arregui et al. (2007), the reduction of water passing sections or sediment accumulation on the inner surface of the turbine chamber are the main causes of over-registration error in single-jet water meters.

The parameter that may have had an influence on the rapid deterioration of all models was the inclination in which many of them were installed in this water supply (Figure 4).

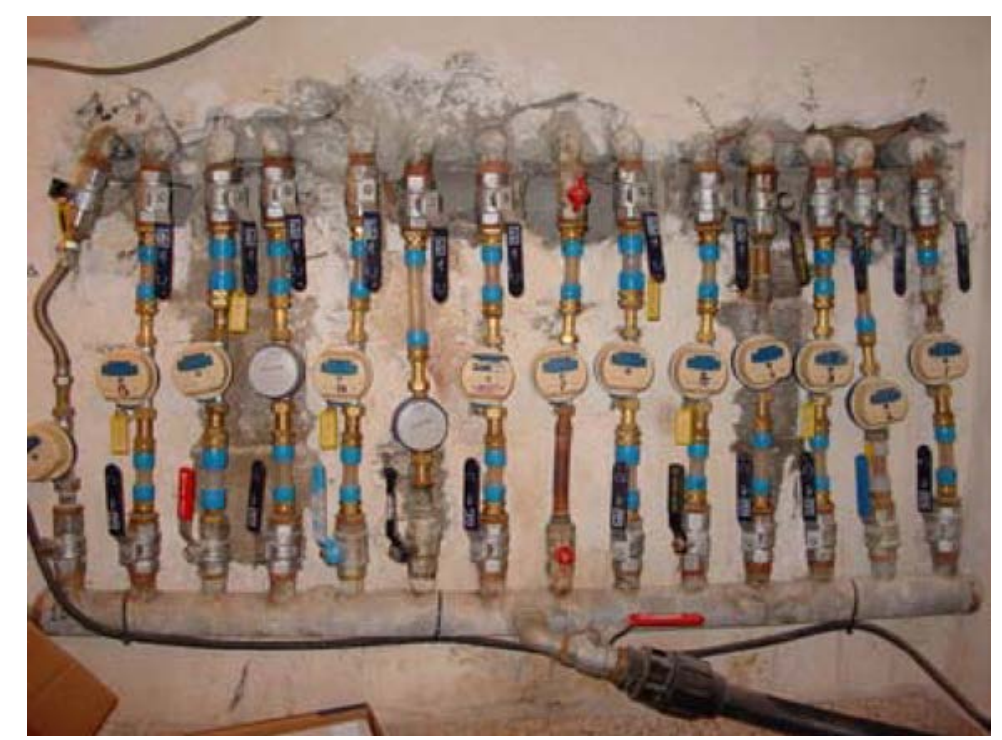

Figure 4. Inadequate mounting position of some evaluated single-jet meters. 
The inappropriate installation of water meters increases the friction of the moving parts and leads to a higher degradation rate of the equipment (Figure 3). This effect is even more visible at low flows rates (Arregui et al., 2005).

\subsection{Analysis by water meter model}

In general, comparing the errors of the main models of each water supply shows that their performance is quite similar. Age is the parameter that most affects their deterioration (Table $3)$.

Table 3. Measurement errors of the single-jet water meters in service, organized by model.

\begin{tabular}{cccccccc}
\hline \multirow{2}{*}{ Model } & \multirow{2}{*}{ Water supply } & NMT & AA (year) & \multicolumn{5}{c}{ Measurement error (\%) } \\
\cline { 5 - 8 } & & & & $\left(30 \mathrm{~L} \mathrm{~h}^{-1}\right)$ & $\left(120 \mathrm{~L} \mathrm{~h}^{-1}\right)$ & $\left(750 \mathrm{~L} \mathrm{~h}^{-1}\right)$ & $\left(1,500 \mathrm{~L} \mathrm{~h}^{-1}\right)$ \\
\hline & 1 & 70 & 8.20 & $-42.7 \pm 10.1$ & $-3.0 \pm 2.7$ & $-0.9 \pm 0.9$ & $-0.4 \pm 0.8$ \\
$\mathrm{a}$ & 3 & 7 & 10.10 & -62.80 & -0.60 & 0.30 & 0.30 \\
& 4 & 35 & 7.20 & $-26.8 \pm 13.2$ & $-0.4 \pm 0.9$ & $-0.8 \pm 0.8$ & $-0.3 \pm 0.8$ \\
& 6 & 251 & 9.80 & $-52.2 \pm 5.1$ & $-6.9 \pm 1.6$ & $-1.9 \pm 0.3$ & $-1.1 \pm 0.3$ \\
\hline & 2 & 17 & 3.90 & $-24.3 \pm 18.2$ & $-1.3 \pm 1.7$ & $-0.8 \pm 0.5$ & $-0.7 \pm 0.4$ \\
$\mathrm{c}$ & 4 & 40 & 3.70 & $-17.3 \pm 10.1$ & $-0.8 \pm 1.6$ & $-1.2 \pm 1.6$ & $1.3 \pm 1.6$ \\
& 6 & 11 & 5.80 & $-29.8 \pm 22.6$ & $-0.5 \pm 1.1$ & $-1.4 \pm 1.1$ & $-0.9 \pm 0.4$ \\
\hline & 1 & 3 & 7.00 & -34.40 & -5.20 & -3.10 & -2.70 \\
$\mathrm{~d}$ & 3 & 11 & 16.40 & $-30.3 \pm 26.6$ & $1.3 \pm 3.2$ & $0.6 \pm 2.1$ & $2.0 \pm 2.2$ \\
& 4 & 39 & 6.80 & $-5.3 \pm 5.0$ & $-0.6 \pm 0.4$ & $-0.2 \pm 0.4$ & $0.3 \pm 0.4$ \\
& 6 & 3 & 13.00 & -20.70 & 2.20 & -1.60 & -1.80 \\
\hline & 2 & 3 & 5.30 & -42.50 & -4.40 & -0.50 & -0.70 \\
$\mathrm{~g}$ & 5 & 64 & 4.70 & $-14.8 \pm 6.5$ & $-2.1 \pm 1.4$ & $-0.1 \pm 0.7$ & $1.0 \pm 0.4$ \\
& 6 & 7 & 8.40 & -30.30 & 1.30 & 0.60 & 1.90 \\
\hline
\end{tabular}

NMT: number of water meters tested; AA: average age.

In the same way as in the supply analysis, the models investigated have similar measurement errors. Mostly negative errors, decreasing as the flow rate increases, with accused values at lower flow rates. Main models performance clearly show, considering the low flow rates, that measurement error increases with the time of use.

Similar results were found in Kampala, Uganda. Residential water meters with 10 and 20 years of use and low pressures in water network were the main cause of under-registration (Mutikanga et al., 2011). In Palermo, Italy, in the same way, meters with 0 to 45 years of use had negative errors that increased rapidly with age (Criminisi et al., 2009).

Fontanazza et al. (2013) indicates that age and pressure are relevant factors to determine the starting flow rate of the meter, considered the main parameter that influences operation. The wear caused by age increases the meter mechanism friction, increasing the resistance to begin the movement of the turbine, especially when the pressure is reduced. In this situation, the water meter considerably increases the unregistered volume of water by not recording consumption or by doing so improperly.

The comparison of similar models with the same age in different supplies shows that the variability between them can be explained by the different operating conditions: installation conditions, water quality, hydraulic parameters of the network, etc. (Arregui et al., 2005, 2018; Buck et al., 2012; Mbabazi et al., 2015).

In Model 'a', meters installed in supplies 1 and 6 had certain characteristics that accentuates their deterioration with respect to supply 4 . In these cases, meters presented a wrong installation 
in the majority of the samples. In Models ' $c$ ' and 'd', operating conditions in supply 4 were more favorable than in supplies 1 or 2 for the period of use from 4 up to 7 years, respectively. In Model ' $g$ ', similar to other models, supply conditions in 5 were more favorable than supply conditions 2.

The comparison between different models can be done in supply 4 that permits comparison to models with similar ages. In this case, Model 'a' presents higher deterioration than Model 'd', especially at low flow rates. This wear can be attributed to manufacturing differences that normally affect metering (Sumrak et al., 2016).

The Figure 5 shows Model 'a' water meters by age groups to obtain the error evolution over time for each flow rate tested.

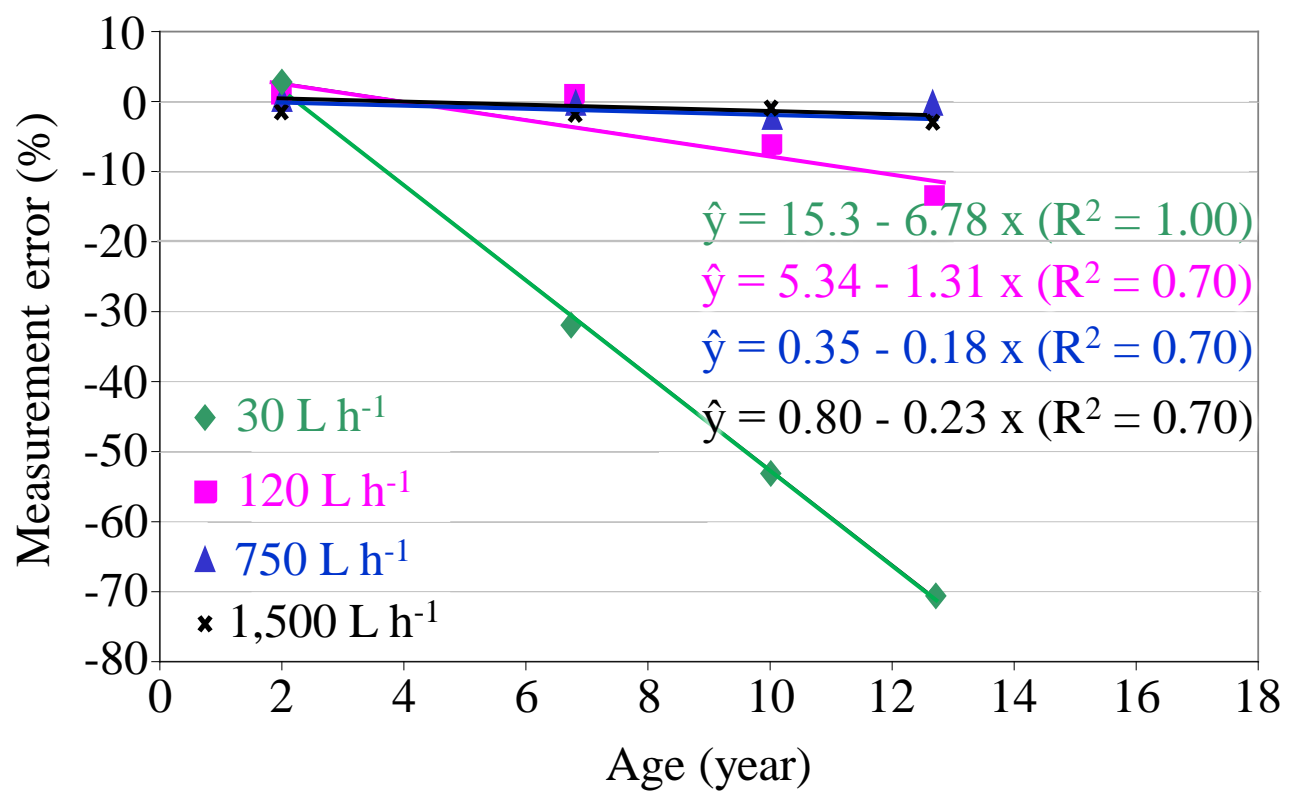

Figure 5. Measurement error of the single-jet water Model 'a' meters, depending on the time of use.

According to Figure 5, measuring errors for meters up to 2 years in service remain within the recommended limit of $\pm 5 \%$ at all flow rate tested.

Over time of use, the rates of deterioration vary depending on the consumption flow rate patterns of the users. Regarding consumption at higher flow rates of 750 and 1,500 $\mathrm{L} \mathrm{h}^{-1}$, errors are repeated during the study period, ranging from -0.5 to $-1.5 \%$ per year and within the limit of $\pm 2 \%$. Only after about 13 and 12 years of use, respectively, would deterioration be considerable. Working at low flow rates of $120 \mathrm{~L} \mathrm{~h}^{-1}$ and, especially, $30 \mathrm{~L} \mathrm{~h}^{-1}$, the errors exceed the limit of $\pm 5 \%$, suggesting the substitution in approximately 8 and 3 years, respectively. Therefore, water meters working at low flow rates during long periods will worsen easily.

It should be noted that age is one of the crucial parameters for the renewal decision-making process. However, in recent strategies to replace water meters, in addition to age, factors such as total volume passing through the meter and the network pressure are considered (Puleo et al., 2014). Also, the price of water, the consumption volume or the cost of acquiring and installing the meter can help to make the decision (Arregui et al., 2011).

Single-jet water meters in service tends to shift the error curve to the right, registering water consumption inadequately over time. As already mentioned, improper installation resulting in increased turbine friction, particle accumulation causing partial obstructions and other factors can accelerate the deterioration of the equipment. Particularly, this phenomenon is enlarged at low flow rates. For example, at $30 \mathrm{~L} \mathrm{~h}^{-1}$, where water driving forces are lower 
and the greater friction caused by the wear of internal parts is more appreciable in meter accuracy.

However, as the instrument ages, the deterioration can appear in higher flow rates as verified in the 120,750 and $1,500 \mathrm{~L} \mathrm{~h}^{-1}$.

\section{CONCLUSIONS}

The study of metrological performance of several models of single-jet water meters in service shows that most equipment has increased under-registration errors over time. These measuring errors are greater at low flow rates and under less favorable operating conditions. In addition, the study allows estimating the measurement error with the service time to evaluate the metrological operation period of the equipment. This period, for the tested flow rates of 30 , 120, 750 and 1,500 L h hes is estimated at approximately 3, 8, 14 and 13 years, respectively.

Unaccounted volume of water depends on the consumption pattern of users. If percentage of consumption is higher at high flow rates, the volume not registered will be less. On the contrary, if the percentage of user consumption at low flow rates is higher, unaccounted water volume will also be high.

\section{REFERENCES}

ARREGUI, F.; CABRERA JUNIOR, E.; COBACHO, R.; GARCIA-SERRA, J. Key factors affecting water meter accuracy. In: IWA SPECIAL CONFERENCE - LEAKAGE, 2005, Halifax. Procedings... Halifax: IWA, 2005. p. 1-10.

ARREGUI, F. J.; CABRERA JUNIOR, E.; COBACHO, R. Integrated water meter management. London: International Water Association, 2007. 272 p.

ARREGUI, F. J.; COBACHO, R.; CABRERA JUNIOR, E.; ESPERT, V. Graphical method to calculate the optimum replacement period for water meters. Journal of Water Resources Planning and Management, v. 137, n. 1 p. 143-146, 2011. https://doi.org/10.1061/(ASCE)WR.1943-5452.0000100

BUCK, B. S.; JOHNSON, M. C.; BARFUSS, S. L. Effects of particulates on water meter accuracy through expected life. Journal of the American Water Works Association, v. 104, n. 4, p. 231-242, 2012. https://doi.org/10.5942/jawwa.2012.104.0054

CICHOŃ, T.; KRÓLIKOWSKA, J. The impact of some external factors on the metrological properties of a water meter. Czasopismo Techniczne, v. 3, n. 1, p. 3-11, 2016. https://doi.org/10.4467/2353737XCT.15.355.4820

COUVELIS, F. A.; VAN ZYL, J. E. Apparent losses due to domestic water meter underregistration in South Africa. Water SA, v. 41, n. 5, p. 698-704, 2015. https://doi.org/10.4314/wsa.v41i5.13

CRIMINISI, A.; FONTANAZZA, C. M.; FRENI, G.; LA LOGGIA, G. Evaluation of the apparent losses caused by water meter under-registration in intermittent water supply. Water Science and Technology, v. 60, n. 9, p. 2373-2382, 2009. https://doi.org/10.2166/wst.2009.423

DANESHNIA, F.; AMINI, A.; CHAICHI, M. R. Berseem clover quality and basil essential oil yield in intercropping system under limited irrigation treatments with surfactant. Agricultural Water Management, v. 164, p. 331-339, 2015. https://doi.org/10.1016/j.agwat.2015.10.036 
FONTANAZZA, C. M.; NOTARO, V.; PULEO, V.; FRENI, G. Effects of network pressure on water meter under-registration: an experimental analysis. Drinking Water Engineering and Science Discussions, v. 6, n. 1, p. 119-149, 2013. https://doi.org/10.5194/dwesd-6-119-2013

INTERNATIONAL ORGANIZATION FOR STANDARDIZATION. ISO 8316. Measurement of liquid flow in closed conduits -- Method by collection of the liquid in a volumetric tank. Geneva, 1987. $21 \mathrm{p}$.

INTERNATIONAL ORGANIZATION FOR STANDARDIZATION. ISO 4064. Measurement of water flow in closed conduits -- Meters for cold potable water -Part 1: Specifications. Geneva, 1993. 6 p.

INTERNATIONAL ORGANIZATION FOR STANDARDIZATION. ISO 4064. Water meters for cold potable water and hot water -- Part 1: Metrological and technical requirements. Geneva, 2014. 38 p.

MBABAZI, D.; BANADDA, N.; KIGGUNDU, N.; MUTIKANGA, H.; BABU, M. Determination of domestic water meter accuracy degradation rates in Uganda. Journal of Water Supply: Research and Technology-AQUA, v. 64, n. 4, p. 486-492, 2015. https://doi.org/10.2166/aqua.2015.083

MUTIKANGA, H. E.; SHARMA, S. K.; VAIRAVAMOORTHY, K. Investigating water meter performance in developing countries: a case study of Kampala, Uganda. Water SA, v. 37, n. 4, p. 567-574, 2011. https://doi.org/10.4314/wsa.v37i4.18

PANTON, R. Calibration and standards in flow measurement. In: SYDENHAM, P. H.; THORN, R. (Eds.). Handbook of measuring system design. Nova Jersey: Wiley, 2005. p. 1-5.

PULEO, V.; FONTANAZZA, C. M.; NOTARO, V.; DE MARCHIS, M.; LA LOGGIA, G.; FRENI, G. Definition of water meter substitution plans based on a composite indicator. $\begin{array}{lllllll}\text { Procedia Engineering, } & \text { v. 70, n. 1, p. 1369-1377, }\end{array}$ https://doi.org/10.1016/j.proeng.2014.02.151

SHIELDS, D. J.; BARFUSS, S. L.; JOHNSON, M. C. Revenue recovery through meter replacement. American Water Works Association, v. 104, p. 252-259, 2012. https://doi.org/10.5942/jawwa.2012.104.0056

SILVA, D. G. M.; ERAZO, J. G.; CRUZ, A. M. O. Eficiencia en el consumo de agua de uso residencial. Revista Ingenierías Universidad de Medellín, v. 11, n. 21, p. 23-38, 2012.

SUMRAK, M. L.; JOHNSON, M. C.; BARFUSS, S. L. Comparing low flow accuracy of mechanical and electronic meters. Journal of the American Water Works Association, v. 108, n. 1, p. E327-E334, 2016. https://doi.org/10.5942/jawwa.2016.108.0069

SZILVESZTER, S.; BELTRAN, R.; FUENTES, A. Performance analysis of the domestic water meter park in water supply network of Ibarra, Ecuador. Urban Water Journal, v. 14, n. 1, p. 85-96, 2017. https://dx.doi.org/10.1080/1573062X.2015.1057181

WALTER, D.; MASTALLER, M.; KLINGEL, P. Accuracy of single-jet and multi-jet water meters under the influence of the filling process in intermittently operated pipe networks. American Water Works Association, v. 18, n. 2, p. 679-687, 2018. https://doi.org/10.2166/ws.2017.149 


\begin{tabular}{|} 
Ambiente \& Água - An Interdisciplinary Journal of Applied Science \\
ISSN 1980-993X - doi:10.4136/1980-993X \\
www.ambi-agua.net \\
E-mail: ambi.agua@gmail.com
\end{tabular}

\title{
Optimization of nitrogen and phosphorus removal from pig slaughterhouse and packing plant wastewater through electrocoagulation in a batch reactor
}

\author{
ARTICLES doi:10.4136/ambi-agua.2233 \\ Received: 23 Jan. 2018; Accepted: 24 Jul. 2018 \\ Fábio Orssatto $^{1 *}$; Maria Hermínia Ferreira Tavares ${ }^{2}$; \\ Flávia Manente da Silva ${ }^{1}$; Eduardo Eyng ${ }^{3}$; Leandro Fleck ${ }^{2}$ \\ ${ }^{1}$ Universidade Tecnológica Federal do Paraná (UTFPR), Medianeira, PR, Brasil \\ Departamento Acadêmico de Ciências Biológicas e Ambientais. \\ E-mail: orssatto@utfpr.edu.br, flavinha_msilva@hotmail.com \\ ${ }^{2}$ Universidade Estadual do Oeste do Paraná (UNIOESTE), Cascavel, Paraná, Brasil \\ Programa de Pós-Graduação em Engenharia Agrícola. E-mail: mhstavar@gmail.com, \\ fleckmissal@gmail.com \\ ${ }^{3}$ Universidade Tecnológica Federal do Paraná (UTFPR), Medianeira, PR, Brasil \\ Programa de Pós-Graduação em Tecnologias Ambientais. E-mail: eduardoeyng@utfpr.edu.br \\ "Corresponding author
}

\begin{abstract}
This work evaluated the removal of total Kjeldahl nitrogen (TKN) and total phosphorus (P) through electrocoagulation and used aluminum electrodes to optimize the potential differential (pd) and hydraulic retention time (HRT) variables in a batch reactor. The experimental design used was Rotatable Central Composite Design (RCCD). The application of the electrocoagulation in the treatment of effluents from pig slaughterhouses and packing plants proved to be efficient in relation to the removal of TKN and total phosphorus, obtaining maximum efficiency equal to $67.15 \%$ and $99 \%$, respectively. The maximum TKN removal value was found in Test 12, where treatment conditions were 30 minutes for HRT and 20 volts for pd, which corresponds to $0.86 \mathrm{~A}$ of electric current and a current density of $17.2 \mathrm{~mA} \mathrm{~cm} \mathrm{~cm}^{-2}$. For P, the only test that removed below $99 \%$ was the first. Through statistical analyses, it was only possible to obtain a mathematical model for TKN removal. While the response surface graph did not present a defined range of the best conditions for the independent variables, it was possible to observe the tendency for better removal, a wide range of $\mathrm{pd}$ and values over 30 minutes for retention time.
\end{abstract}

Keywords: electroflotation, electrolytic treatment, nutrients.

\section{Otimização da remoção de nitrogênio e fósforo de efluente de matadouro e frigorífico de suínos por meio da eletrocoagulação em reator batelada}

\section{RESUMO}

O objetivo desse trabalho foi avaliar a remoção de nitrogênio total kjeldahl (NTK) e fósforo total (P) através da eletrofloculação e otimizar as variáveis diferencial de potencial (ddp) e tempo de detenção hidráulica (TDH) em um reator batelada utilizando eletrodos de alumínio. 
O delineamento experimental utilizado foi o DCCR. A aplicação da técnica da eletrofloculação no tratamento de efluentes de matadouros e frigoríficos de suínos demonstrou ser eficiente no que tange a remoção de NTK e fósforo total obtendo-se eficiência máxima igual a $67,15 \%$ e $99 \%$, respectivamente. O valor máximo de remoção de NTK foi encontrado no ensaio 12, onde as condições de tratamento foram de 30 minutos para o TDH e 20 volts para a ddp o que corresponde a 0,86 A de corrente elétrica e uma densidade de corrente igual a 17,2 $\mathrm{mA} \mathrm{cm}$. Para o P, o único ensaio que removeu abaixo de $99 \%$ foi o primeiro. Através das análises estatísticas, foi possível obter modelo matemático apenas para a remoção de NTK, entretanto o gráfico da superfície de resposta não apresentou uma faixa definida das melhores condições para as variáveis independentes, mas foi possível observar a tendência para melhor remoção, uma ampla faixa de ddp e valores acima de 30 minutos para o tempo de detenção.

Palavras-chave: eletroflotação, nutrientes, tratamento eletrolítico.

\section{INTRODUCTION}

The production of pork in Brazil has great relevance for the country's economy. According to ABPA (2017), Brazil produced 3.73 million tons of pork in 2016, ranking 4th in the world.

Pig slaughterhouses and packing plants generate a large amount of effluents, which consist of protein, fat, salts, animal manure and other substances. This waste therefore has a high degree of pollution, with high levels of organic matter, oils and greases, nutrients and total solids.

In addition to the high degree of pollution, the meat processing industry produces large volumes of wastewater due to the slaughter of animals and the cleaning of slaughterhouses and meat processing plants (Bustillo-Lecompte and Mehrvar, 2015). The meat processing industry uses $24 \%$ of the total fresh water consumed by the food and beverage industry and up to $29 \%$ of the worldwide agricultural sector demand (Mekonnen and Hoekstra, 2012; Gerbens-Leenes et al, 2013).

In addition to the large amount of effluent generated, the wastewater from the slaughterhouses and packing plants contains several types of pollutants, among them nutrients.

Nutrients released into the water, especially nitrogen and phosphorus, contribute to the increase of primary productivity of the system, resulting in an accumulation of organic matter and reduction of light penetration (Azevedo et al., 2008).

Because of this, removing such nutrients from the wastewater is indispensable to minimize the impacts caused to the receiving bodies. Several techniques can be used to treat effluents generated in productive processes.

Jaafari et al. (2017) used Moving Bed Biofilm Reactors (MBBRs) for the simultaneous removal of organic matter and nutrients from wastewater. In this same context, Safari et al. (2015) and Naghipour et al. (2015) used the adsorption and biosorption processes for the removal of phosphorus in aqueous solutions.

Techniques involving electrochemical reactions have been studied in environmental applications, especially in the treatment of wastewater. One such process is electrocoagulation (EC) which has gained attention because of its attractive advantages such as simplicity and low operating cost (Deghles and Kurt, 2016).

EC involves the dissolution of a metal (usually iron or aluminum) in the anode with the simultaneous formation of hydroxyl ions, and the generation of hydrogen gas in the cathode, which can be recovered for use as an energy source or a reagent for other industrial applications (Phalakornkule et al., 2010).

According to Crespilho and Rezende (2004), EC occurs in four stages: electrochemical generation of the coagulating agent, electrocoagulation, electroflocculation and flotation of the impurities. 
The electrochemical generation of the coagulating agent occurs from the dissolution of the anode of aluminum electrodes subjected to an obtained electric current. In addition to the electric current, other factors should be considered, such as the conductivity of the solution, the resistivity of the medium and the potential applied between the electrodes (Crespilho and Rezende, 2004).

In electrocoagulation, the positively charged material can react with the negative charges of the solution. This causes the hydrolysis that releases aluminum hydroxide, responsible for the treatment of the effluent submitted to the process (Brito et al., 2012).

In the electroflocculation stage, the aluminum complexes are adsorbed in colloidal particles, giving rise to larger particles. This step consists of greater destabilization of the system and the flocs can be removed through flotation (Crespilho and Rezende, 2004).

Finally, electroflotation promotes the separation of the impurities by flotation. This occurs due to the applied potential-forming hydrogen microbubbles in the cathode. The formed hydrogen bubbles promote the entrainment of the formed flocs to the surface of the solution. An example of application using electrocoagulation with aluminum electrodes is the work of Esfandyari et al. (2015).

This work evaluated the removal of total Kjeldahl nitrogen (TKN) and total phosphorus (P) through electrocoagulation, and used aluminum electrodes to optimize the potential differential (pd) and hydraulic retention time (HRT) variables in a batch reactor.

\section{MATERIALS AND METHODS}

\subsection{Effluent from pig slaughterhouses and processing plants}

The effluent used in the study came from a pig slaughterhouse and a packing plant located in the western region of Paraná. This industry slaughters approximately 6,500 animals, producing a discharge of $5,200 \mathrm{~m}^{3}$ of effluent per day.

The treatment system of the studied plant is composed of preliminary treatment with sieves, decanters and grease traps, which aim to eliminate coarse solids, oils and greases from industrial activities.

In the sequence, the effluent is directed towards biological treatment, with a sequence of four lagoons, which carry out the removal of carbonaceous and nitrogenous organic matter, along with residual solids and pathogens. As a post-treatment, the effluent passes through a float, being then directed to the river.

The effluent used for the electrocoagulation tests was collected after the discharge of the decanters/grease traps, and was characterized by total Kjeldahl nitrogen $\left(4500-\mathrm{N}_{\text {org }} \mathrm{B}\right)$, total phosphorus (4500-PE), $\mathrm{pH}\left(4500-\mathrm{H}^{+} \mathrm{B}\right)$ and conductivity $(2510 \mathrm{~B})$, in accordance with APHA protocols (APHA et al., 2005).

\subsection{Batch experimental system}

The electrocoagulation treatment system consisted of a batch bench reactor composed of a 1-liter beaker containing $800 \mathrm{~mL}$ of effluent in each test. This system was maintained under constant stirring by means of a magnetic stirrer and a magnetic bar placed inside the beaker.

In order to provide the electric current that makes the electrocoagulation process viable, a direct current source, in which two metallic aluminum electrodes were connected and immersed in the effluent, was used. The electrodes were arranged at a distance of $7.8 \mathrm{~cm}$ and each plate was $10 \mathrm{~cm}$ long and $5 \mathrm{~cm}$ wide.

The best conditions for the treatment of the effluent were determined by testing different values for the variables: potential differential (pd) and hydraulic retention time (HRT). 


\subsection{Evaluation of the system}

To verify the best efficiency, the removal of Total Kjeldahl Nitrogen (TKN) and Total Phosphorus (P) was considered. The values of electric current (A) were also recorded so that it was possible to calculate the current density $\left(\mathrm{mA} \mathrm{cm}^{-2}\right)$.

\subsection{Experimental planning}

The design used was the Rotatable Central Composite Design (RCCD). As two independent variables (pd and HRT) were worked, a complete $2^{2}$ factorial was performed, including four axial points and four repetitions at the central point, totaling 12 tests.

Table 1 shows the number of tests with the coded and actual values, which were defined from pretests with the effluent. These pretests also showed that the addition of alkaline agents was not necessary and that the effluent had the necessary electrical conductivity for electrocoagulation to occur.

Table 1. Number of tests with coded values.

\begin{tabular}{ccc}
\hline Tests & pd $(\mathrm{V})$ & HRT $(\mathrm{min})$ \\
\hline 1 & $-1(12,91)$ & $-1\left(12^{\prime} 55^{\prime \prime}\right)$ \\
2 & $+1(27,09)$ & $-1\left(12^{\prime} 55^{\prime \prime}\right)$ \\
3 & $-1(12,91)$ & $1\left(27^{\prime} 05^{\prime \prime}\right)$ \\
4 & $+1(27,09)$ & $1\left(27^{\prime} 05^{\prime}\right)$ \\
5 & $0(20)$ & $0(20)$ \\
6 & $0(20)$ & $0(20)$ \\
7 & $0(20)$ & $0(20)$ \\
8 & $0(20)$ & $0(20)$ \\
9 & $-1,41(10)$ & $0(20)$ \\
10 & $+1,41(30)$ & $0(20)$ \\
11 & $0(20)$ & $-1,41(10)$ \\
12 & $0(20)$ & $+1,41(30)$ \\
\hline
\end{tabular}

From the results, it was possible to calculate the effects of the variables, the respective errors and the analysis of variance (ANOVA) to verify the quality of adjustment of the obtained model, which related the response variable to the other independent variables tested, as well as the effect among these. The graphical representation of this model consisted of a surface chart, which aided in the determination of the optimum operating region of the system.

The regression analysis of the data obtained through the RCCD allowed for the adjustment of the parameters of quadratic models of the response variables, as a function of the studied factors and their interactions. Equation 1 represents a general model to be obtained, and the $\alpha$ parameters were adjusted by regression analysis.

Removal of TKN or $P=\alpha_{1}+\alpha_{2} p d+\alpha_{3} H R T+\alpha_{4} p d . H R T+\alpha_{5} p d^{2}+\alpha_{6} H R T^{2}$

Where HRT is time in minutes and pd is the potential differential in volts.

\section{RESULTS AND DISCUSSION}

\subsection{Characterization of the crude effluent}

Regarding the characterization of the crude effluent, the following values were found: $289.8 \mathrm{mgN} \mathrm{L}^{-1}$ for the total Kjeldahl nitrogen parameter, $38 \mathrm{mgP} \mathrm{L}^{-1}$ for phosphorus, $3.91 \mathrm{mS} \mathrm{cm}^{-1}$ for conductivity and a $\mathrm{pH}$ equal to 6.46 .

In analyzing the values, it was observed that the majority of the parameters had high 
indexes, with the exception of $\mathrm{pH}$. Corroborating with the found values, Bustillo-Lecompte et al. (2014) report that wastewater from packing plants may have total nitrogen concentrations ranging from 50 to $841 \mathrm{mg} \mathrm{L}^{-1}$ and a $\mathrm{pH}$ range of 4.90 to 8.10 .

Pan et al. (2014) found, on average, $172.6 \mathrm{mg} \mathrm{L}^{-1}$ of total nitrogen and $52 \mathrm{mg} \mathrm{L}^{-1}$ total phosphorus, when characterizing packing plant effluent.

Palatsi et al. (2011), in their work on the biodigestion of packing plant waste, characterized the effluent and found on average $150 \mathrm{mg} \mathrm{L}^{-1}$ of total Kjeldahl nitrogen.

\subsection{Efficiency of removal}

Figure 1 shows the removal efficiency values for TKN and Total Phosphorus parameters in the 12 tests performed.

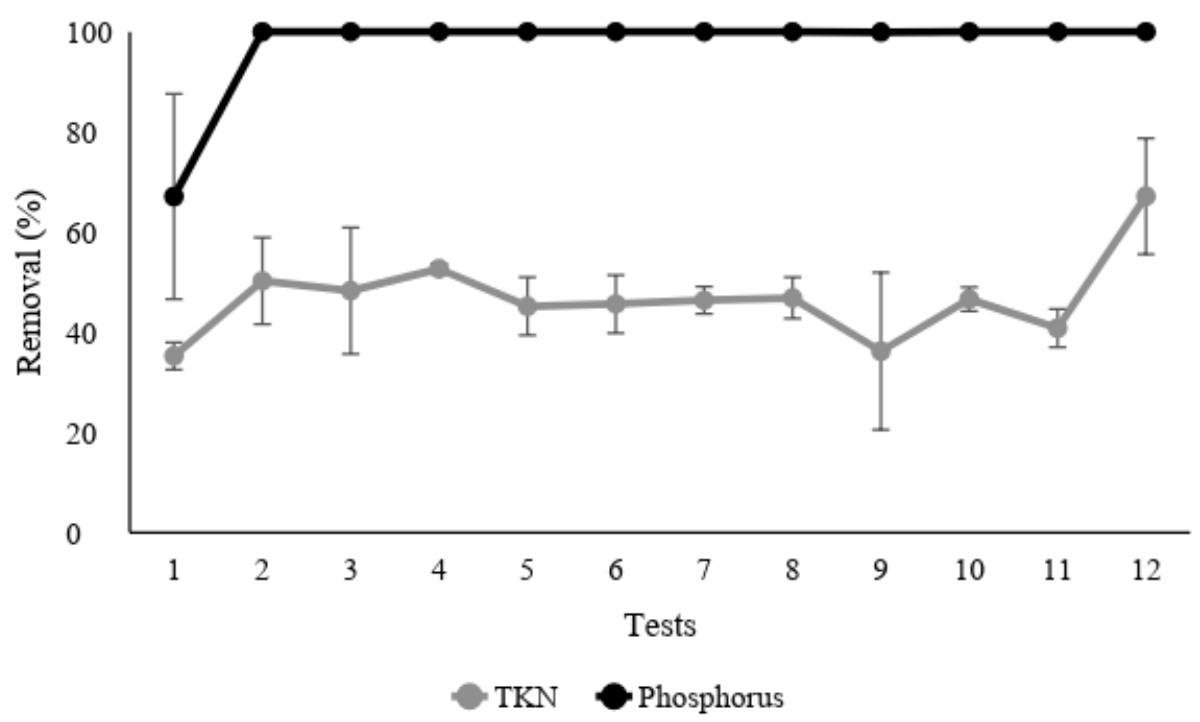

Figure 1. Efficiency of removal of TKN and total phosphorus parameters.

Different behaviors for the removal of TKN and phosphorus can be observed in the graph in Figure 1, such as a high efficiency for phosphorus and satisfactory removal of TKN.

For phosphorus, the lowest removal occurred in Test $1,67.10 \%( \pm 20,47)$, and the other tests showed efficiency above 99\%. Nunes (2012) points out that the use of chemical precipitation is common for the removal of phosphorus and, for this to occur, aluminum sulfate or the combination of ferric chloride with lime is used. With the use of aluminum sulfate, a $95 \%$ removal of phosphorus can be obtained, a result similar to the one previously found, as the electrodes used were aluminum.

According to Nunes (2012), the phosphorus is removed as phosphate $\left(\mathrm{PO}_{4}{ }^{3-}\right)$ and the chemical reaction outlined in Equation 2 occurs.

$\mathrm{Al}^{3+}+\mathrm{PO}_{4}^{3-} \rightarrow \mathrm{AlPO}_{4}$

Gökkus and Yildiz (2015) applied electrocoagulation in the treatment of wastewater from hospital waste-sterilization plants; they removed $100 \%$ of the phosphorus present in the effluent.

While studying phosphorus removal and turbidity of pork effluent with aluminum electrodes, HRT of $80 \mathrm{~min}$ and current density of $50 \mathrm{~mA} \mathrm{~cm}{ }^{-2}$, Mores et al (2016) obtained a removal of $93.6 \%$ of total phosphorus.

Khennoussi et al. (2013), when treating wastewater from a slaughterhouse and packing plant with electrocoagulation, applying a voltage of $12 \mathrm{~V}, 25 \mathrm{~min}$ contact time and iron electrodes, obtained a removal of $95.4 \%$ orthophosphate.

\section{IPABH}

Rev. Ambient. Água vol. 13 n. 5, e2233 - Taubaté 2018 
For TKN, the removal efficiency values ranged from $35.26 \%( \pm 2.73)$ to $67.15 \%( \pm 11.61)$. Test 12 showed the best removal efficiency with 30 minutes of hydraulic retention time and 20 volts of potential differential, corresponding to $0.86 \mathrm{~A}$ of electrical current, and current density of $17.2 \mathrm{~mA} \mathrm{~cm}^{-2}$; however, excluding the least efficient test, the variation compared to the other assays was low, having a standard deviation of 7.76 .

Kabuk et al. (2014) applied electrocoagulation in the Leachate treatment and obtained a removal efficiency of TKN removal efficiency of $32 \%$.

Khennoussi et al. (2013), in the same paper cited above, obtained a removal of $76.2 \%$ of total nitrogen.

The biological removal of the nitrogen present in liquid effluents is possible through a series of reactors, where the processes of nitrification and denitrification occur. These methods are efficient; however, they require more time and space since the removal of organic matter must occur first and then the specific removal of nitrogen.

In addition, the process of nitrification and denitrification also demands electric power since it is necessary to supply oxygen to the nitrifying bacteria to convert the ammoniacal nitrogen into nitrite and nitrate, and for homogenization of the denitrification tank.

$\mathrm{Hu}$ et al. (2013) state that for both nitrification and denitrification processes, large energy consumption is required, resulting in relatively high costs for treatment systems.

In this manner, a high removal of nutrients in the electrocoagulation process was observed, using a significantly shorter time than in traditional biological processes.

\subsection{Optimization of the electrocoagulation process}

Through the results, it was possible to evaluate a mathematical model for the removal of TKN and total phosphorus.

Parameters with p-values less than 5\% were considered significant, as can be observed in Figures 2, 3 and in Table 2, which represent the pareto charts for the removal of the parameters studied; the linear terms are associated with the letter $\mathrm{L}$ and the quadratic terms with the letter Q.

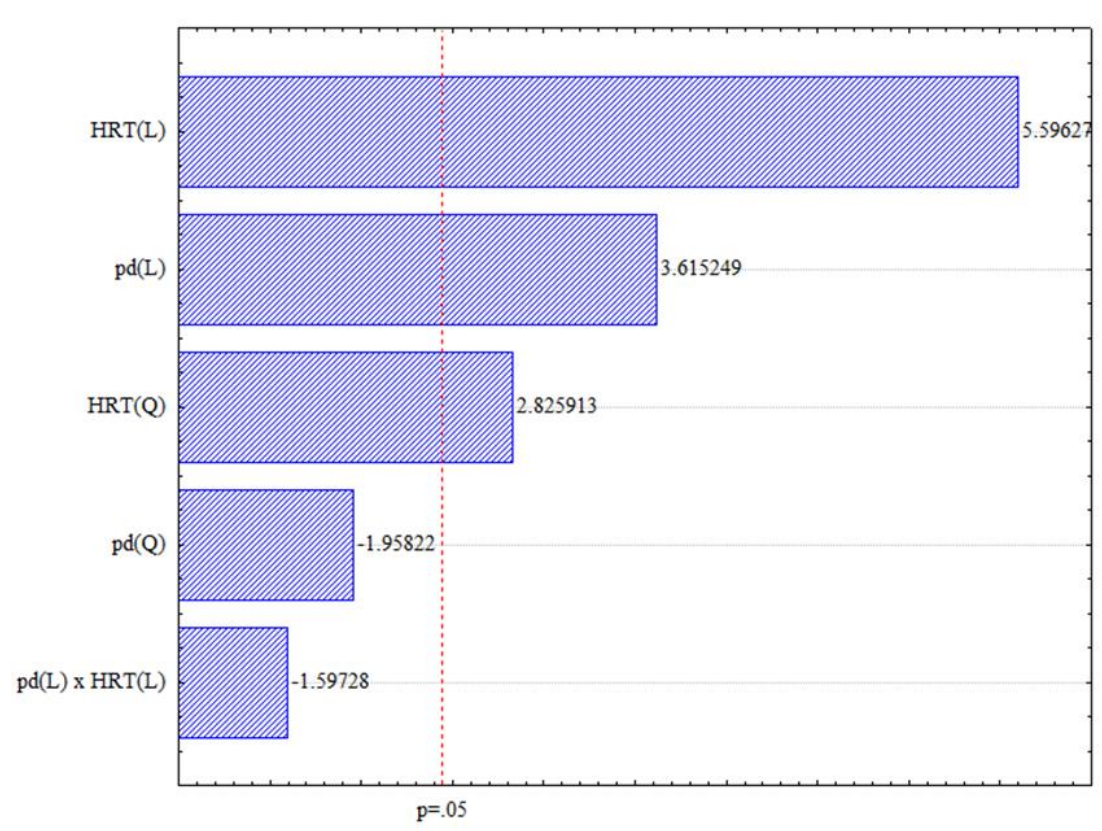

Figure 2. Pareto chart for the removal of TKN. 


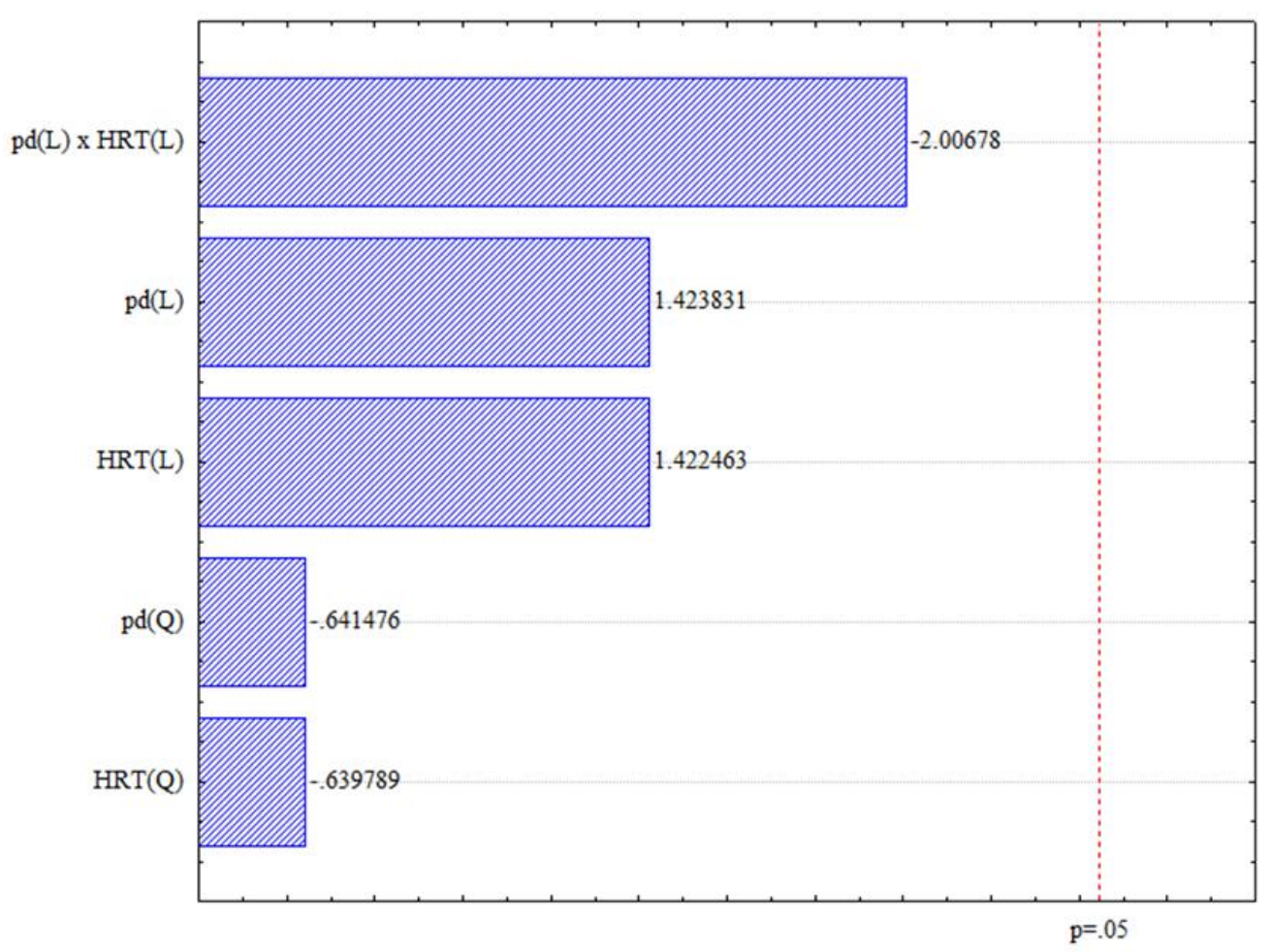

Figure 3. Pareto chart for the removal of total phosphorus.

Table 2. Regression coefficients for the response variable NTK removal.

\begin{tabular}{|c|c|c|c|c|c|c|}
\hline \multirow[b]{2}{*}{ Factors } & \multirow[b]{2}{*}{$\begin{array}{l}\text { Regression } \\
\text { coeficiente }\end{array}$} & \multirow[b]{2}{*}{$\begin{array}{l}\text { Standard } \\
\text { error }\end{array}$} & \multirow[b]{2}{*}{$\mathrm{t}(6)$} & \multirow[b]{2}{*}{$\mathrm{p}$ - value } & \multicolumn{2}{|c|}{ Estimates per interval (95\%) } \\
\hline & & & & & Lower limit & Upper limit \\
\hline Average & 46.01776 & 1.663442 & 27.66419 & 0,000000 & 41.9475 & 50.08805 \\
\hline $\mathrm{pd}(\mathrm{L})$ & 4.25874 & 2.355990 & 3.61525 & 0,011161 & 2.7526 & 14.28239 \\
\hline $\mathrm{pd}(\mathrm{Q})$ & -2.58596 & 2.641143 & -1.95822 & 0,097937 & -11.6346 & 1.29072 \\
\hline HRT (L) & 6.59238 & 2.355990 & 5.59627 & 0,001386 & 7.4199 & 18.94966 \\
\hline $\operatorname{HRT}(\mathrm{Q})$ & 3.73182 & 2.641143 & 2.82591 & 0,030119 & 1.0010 & 13.92629 \\
\hline pd HRT & -2.65700 & 3.326913 & -1.59728 & 0,161317 & -13.4547 & 2.82665 \\
\hline
\end{tabular}

In Figure 2 and Table 2, it can be observed that for the TKN removal variable response the significant terms were pd (L), HRT (L) and HRT (Q).

However, for the total-phosphorus removal response variable (Figure 3), no term was significant, which was already expected when observing the behavior of the values in the chart of Figure 1, as similar removals were obtained for the majority of the assays. Thus, it was only possible to obtain a mathematical model for the TKN removal response variable.

It can be observed that the adjusted model for the TKN response variable was characterized by Equation 3.

Removal of $T K=46.01776+4.25874 p d+6.59238 H R T+3.73182 H R T^{2}$

The analysis of variance (ANOVA) of the results found for the removal of TKN showed that the obtained model fits the data, since the p-value was 0.004685 , with a variation percentage of explained variation $\left(\mathrm{R}^{2}\right)$ of $91.12 \%$ evidencing a valid model. Figure 4 shows the response surfaces for the removal of TKN. 


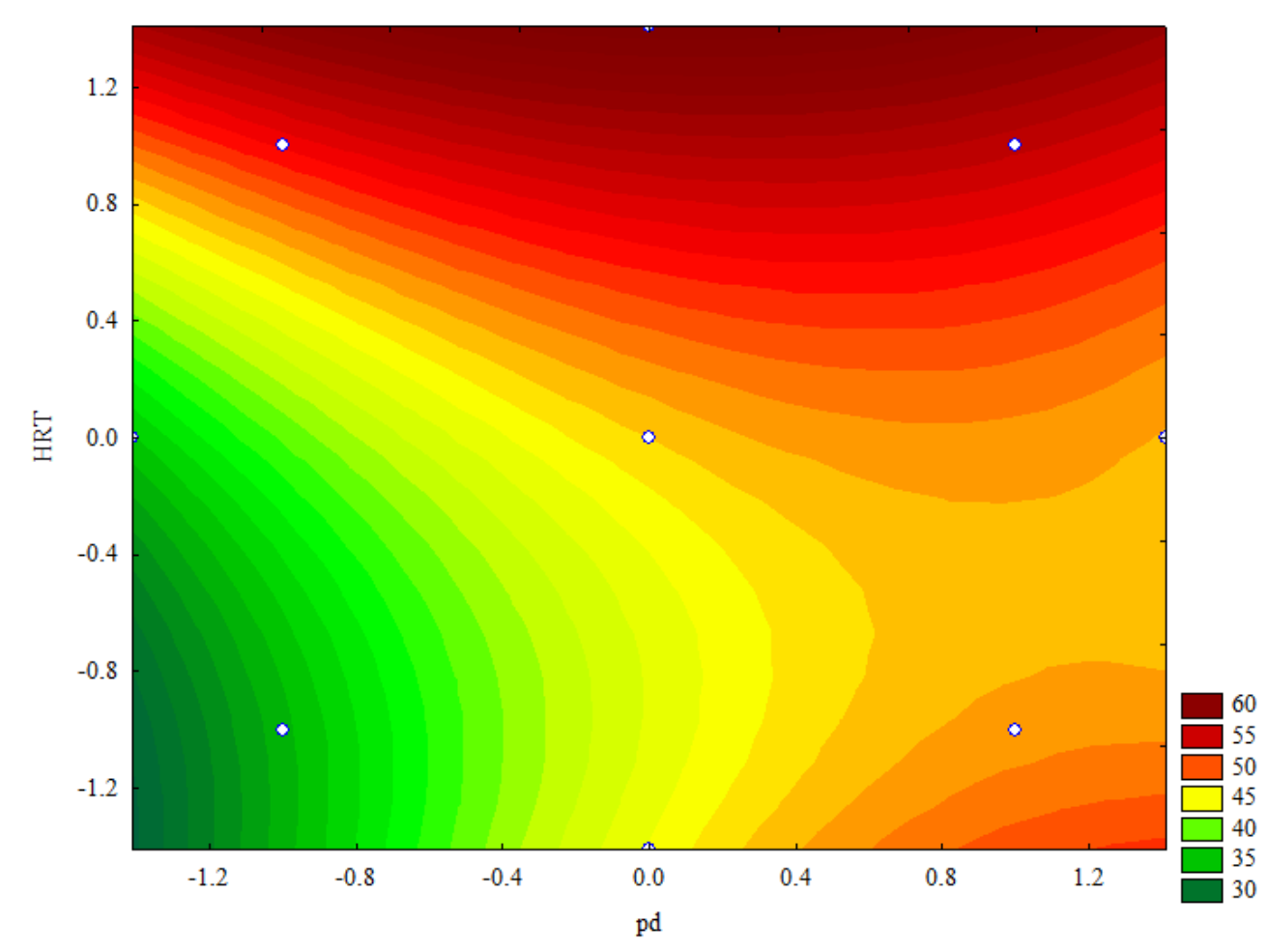

Figure 4. Response surface for removal of TKN.

For TKN removal, the response surface did not present an approximate range for the best removal conditions; however, it is possible to observe a tendency for a better removal, a wide range of pd and values over 30 minutes for retention time.

\section{CONCLUSION}

The objective of this work was to evaluate the removal of total Kjeldahl nitrogen (TKN) and total phosphorus (P) through the electrochemical technique, and to optimize the potential differential (pd) and hydraulic retention time (HRT) variables in a batch reactor of electrocoagulation using aluminum electrodes.

The application of electrocoagulation in the treatment of effluents from pig slaughterhouses and packing plants proved to be efficient in relation to the removal of TKN and total phosphorus, obtaining maximum efficiency equal to $67.15 \%$ for TKN and $99 \%$ for total phosphorus.

The maximum TKN removal value was found in test 12 , where treatment conditions were 30 minutes for HRT and 20 volts for pd, which corresponds to $0.86 \mathrm{~A}$ of electric current and a current density equal to $17.2 \mathrm{~mA} \mathrm{~cm}^{-2}$.

For total phosphorus, the only assay that removed below $99 \%$ was the first, showing that, for phosphorus removal, electrocoagulation is an excellent treatment option.

Through statistical analyses, it was only possible to obtain a mathematical model for the removal of TKN. However, the response surface chart did not present a defined range of the best conditions for the independent variables, but it was possible to observe the tendency for better removal across a wide range of $\mathrm{pd}$ and values above 30 minutes for retention time.

As suggestions for future work, $\mathrm{pH}$ can be evaluated as a variable, even if this implies a change in the initial characteristics of the effluent, in an attempt to increase the efficiency of nitrogen removal. Higher levels of electrolysis time can also be tested since the response surface graph showed a trend of increased efficiency with higher HRT. 


\section{REFERENCES}

AMERICAN PUBLIC HEALTH ASSOCIATION - APHA; AMERICAN WATER WORKS ASSOCIATION - AWWA; WATER ENVIRONMENT FEDERATION - WEF, Standard methods for the examination of water and wastewater. 22. ed. Washington, DC, 2005.ASSOCIAÇÃO BRASILEIRA DE PROTEÍNA ANIMAL - ABPA. Relatório anual. 2017. Disponível em: https://goo.gl/unpxGV Acesso em: jul. 2018.

AZEVEDO, A.C. G de; FEITOSA, F. A. N.; KOENING, M. L. Distribuição espacial e temporal da biomassa fitoplanctônica e variáveis ambientais no Golfão Maranhense, Brasil. Acta Botânica Brasilica, v. 22, n. $\quad 3, \quad 2008$. https://doi.org/10.1590/S010233062008000300022

BRITO, J. F.; FERREIRA, L. O.; SILVA, J. P. Tratamento da água de purificação do biodiesel utilizando eletrofloculação. Química Nova, v. 35, n. 4, 2012. http://dx.doi.org/10.1590/S0100-40422012000400014

BUSTILLO-LECOMPTE, C. F.; MEHRVAR, M. Slaughterhouse wastewater characteristics, treatment, and management in the meat processing industry: A review on trends and advances. Journal of Environmental Management. v. 161, n. 287, 2015. http://dx.doi.org/10.1016/j.jenvman.2015.07.008

BUSTILLO-LECOMPTE, C. F.; MEHRVAR, M.; QUIÑONES-BOLAÑOS, E. Costeffectiveness analysis of TOC removal from slaughterhouse wastewater using combined anaerobic-aerobic and UV/ $\mathrm{H}_{2} \mathrm{O}_{2}$ processes. Journal of Environmental Management. v. 134, 2014. http://dx.doi.org/10.1016/j.jenvman.2013.12.035

CRESPILHO, F. N.; REZENDE, M. O. O. Teoria da eletroflotação. In: CRESPILHO, F. N.; REZENDE, M. O. O. Eletroflotação: Princípios e aplicações. São Carlos: Rima, 2004. p.1-12.

DEGHLES, A.; KURT, U. Treatment of tannery wastewater by a hybrid electrocoagulation/ electrodialysis process. Chemical Engineering and Processing: Process Intensification. v. 104, 2016. http://dx.doi.org.10.1016/j.cep.2016.02.009

ESFANDYARI, Y.; MAHDAVI, Y.; SEYEDSALEHI, M.; HOSEINI, M.; SAFARI, G. H.; GHOZIKALI, M. G. et al. Degradation and biodegradability improvement of the olive mill wastewater by peroxi- electrocoagulation/electrooxidation-electroflotation process with bipolar aluminum electrodes. Environmental Science Pollution Research. v. 22, n. 8, p. 6288-6297, 2015. https://doi.org/10.1007/s11356-014-3832-5

GERBENS-LEENES, P. W.; MEKONNEN, M. M.; HOEKSTRA, A. Y. The water footprint of poultry, pork and beef: a comparative study in different countries and production $\begin{array}{llllll}\text { systems. Water Resources and Industry, v. } 2013 . & \end{array}$ http://dx.doi.org/10.1016/j.wri.2013.03.001

GÖKKUS, Ö.; YILDIZ, Y. S. Application of electrocoagulation for treatment of medical waste sterilization plant wastewater and optimization of the experimental conditions. Clean $\begin{array}{lllllll}\text { Technologies Environmental Policy. } & \text { v. 17, n. 6, } 2015 .\end{array}$ http://dx;doi.org/10.1007/s10098-014-0897-2

HU, Z.; LOTTI, T.; KREUK, M.; KLEERBEZEM, R.; VAN LOOSDRECHT, M; KRUIT, J. et al. Nitrogen removal by a nitritation-anammox bioreactor at low temperature. Applied and Environmental Microbiology, v. 79, n. 8, p. 2807-2812, 2013. http://dx.doi.org/10.1128/AEM.03987-12 
JAAFARI, J.; SEYEDSALEHI, M.; SAFARI, G. H.; ARJESTAN, M. E.; BARZANOUMI, H.; GHADIMI, S. et al. Simultaneous biological organic matter and nutrient removal in an anaerobic/anoxic/oxic (A2O) moving bed biofilm reactor (MBBR) integrated system. International Journal Environmental Science and Technology, v. 14, p. 291-304, 2017. https://doi.org/10.1007/s13762-016-1206-x

KHENNOUSSI, A.; CHAOUCH, M.; CHAHLAOUI, A. Traitement des effluents d'abattoir de viande rouge par électrocoagulation-flottation avec des électrodes en fer. Erudit. v. 26, n. 2, p. 135-150, 2013. http://dx.doi.org/10.7202/1016064ar

KABUK, H. A.; IILHAN, F.; AVSAR, Y.; KURT, U.; APAYDIN, O.; GONULLU, M. T. Investigation of Leachate Treatment with Electrocoagulation and Optimization by Response Surface Methodology. Clean Soil Air Water, v. 42, n. 5, p.571-577, 2014. https://doi.org/10.1002/clen.201300086

MEKONNEN, M.M.; HOEKSTRA, A.Y. A global assessment of the water footprint of farm animal products. Ecosystems. v. 15, n.3, 2012. http://dx.doi.org/10.1007/s 10021-0119517-8

MORES, R.; TREICHEL, H.; ZAKRZEVSKI, C. A.; KUNZ, A.; STEFFENS, J.; DALLAGO, R. M. Remove of phosphorous and turbidity of swine wastewater using electrocoagulation under continuous flow. Separation and Purification Technology. v. 171, 2016. https://doi.org/10.1016/j.seppur.2016.07.016

NAGHIPOUR, D.; TAGHAVI, K.; JAAFARI, J.; MAHDAVI, Y.; GHOZIKALI, M. J.; AMERI, R. et al. Statistical modeling and optimization of the phosphorus biosorption by modified Lemna minor from aqueous solution using response surface methodology (RSM). Desalination and Water Treatment, v. 57, n. 41, p. 19431-19442, 2015. https://doi.org/10.1080/19443994.2015.1100555

NUNES, J. A. Processos químicos específicos e tratamentos terciários. In: NUNES, J. A. Tratamento Físico-Químico de Águas Residuárias Industriais. Aracaju: J. Andrade, 2012. p. 175-208.

PALATSI, J.; VIÑAS, M.; GUIVERNAU, M.; FERNANDEZ, B.; FLOTATS, X. Anaerobic digestion of slaughterhouse waste: Main process limitations and microbial community interactions. Bioresource Technology. $\quad$ v. 102, $\quad$ n. $3,2011$. http://dx.doi.org/10.1016/j.biortech.2010.09.121

PAN, M; WEN, X.; WU, G.; ZHANG, M.; ZHAN, X. Characteristics of nitrous oxide $\left(\mathrm{N}_{2} \mathrm{O}\right)$ emission from intermittently aerated sequencing batch reactors (IASBRs) treating slaughterhouse wastewater at low temperature. Biochemical Engineering Journal. v. 86, 2014. http://dx.doi.org/10.1016/j.bej.2014.03.003

PHALAKORNKULE, C.; SUKKASEM, P.; MUTCHIMSATTHA, C. Hydrogen recovery from the electrocoagulation treatment of dye-containing wastewater. International $\begin{array}{llllllll}\text { Journal Of Hydrogen Energy. } & \text { v. } & 35, & \text { n. } & 2010 .\end{array}$ http://dx.doi.org/10.1016/j.ijhydene.2010.06.100

SAFARI, J. H.; ZARRABI, M.; HOSEINI, M.; KAMANI, H.; JAAFARI, J.; MAHVI, A. H. Trends of natural and acid-engineered pumice onto phosphorus ions in aquatic environment: adsorbent preparation, characterization, and kinetic and equilibrium modeling. Desalination and Water Treatment, v. 54, n. 11, p. 3031-3043. 2015. https://doi.org/10.1080/19443994.2014.915385 


\begin{tabular}{|} 
Ambiente \& Água - An Interdisciplinary Journal of Applied Science \\
ISSN 1980-993X - doi:10.4136/1980-993X \\
www.ambi-agua.net \\
E-mail: ambi.agua@gmail.com
\end{tabular}

\title{
Estimation of corrosive and scaling trend in drinking water systems in the city of Azogues, Ecuador
}

\author{
ARTICLES doi:10.4136/ambi-agua.2237
}

Received: 05 Feb. 2018; Accepted: 20 Aug. 2018

\author{
Fernando García-Ávila ${ }^{1,2 *}$; Lía Ramos-Fernández³ ${ }^{3}$ César Zhindón-Arévalo ${ }^{4}$ \\ ${ }^{1}$ Universidad de Cuenca, Cuenca, Ecuador \\ Facultad de Ciencias Químicas. E-mail: garcia10f@ hotmail.com \\ ${ }^{2}$ Universidad Nacional Agraria La Molina, La Molina, Lima, Peru \\ E-mail: garcia10f@hotmail.com \\ ${ }^{3}$ Universidad Nacional Agraria La Molina, La Molina, Lima, Peru \\ Departamento Académico de Recursos Hídricos. E-mail: liaseptiembre2012@ @otmail.es \\ ${ }^{4}$ Universidad Católica de Cuenca, Azogues, Ecuador \\ Unidad Académica de Salud y Bienestar. E-mail: cezhindona@ucacue.edu.ec \\ "Corresponding author
}

\begin{abstract}
The quality of drinking water flowing in a distribution network can possess corrosive characteristics that may cause the material degradation of pipes and accessories. This problem can result in reduction of the service life of pipes and create a major public health problem. The agreement between the physical-chemical water quality analysis and national standards are not enough to confirm the balance of the water quality in terms of corrosion. In order to predict pipe corrosion in water distribution system networks, the corrosive trend was evaluated using the Langelier (LSI), Ryznar (RSI), and Larson-Skold (LRI) indexes based on measurements of $\mathrm{pH}$, temperature, total dissolved solids, alkalinity, calcium hardness, sulfate and chloride. This study was setup with 180 samples collected in six zones of the distribution network, from July to December of 2017, according to the standard methods for the analysis of drinking water. The results indicate a variation of the LSI from -1.22 to -1.68 ; RSI from 9.75 to 10.52 and LRI from 0.46 to 0.77 . A linear model was fitted for each index to predict the corrosion with the water quality conditions of this study case. Therefore, the drinking water of the city of Azogues, Ecuador has a corrosive tendency from significant to severe. Corrosion indices were calculated to provide useful information on the water's corrosiveness. These results indicate the need to constantly monitor the corrosion rate in the distribution network and conduct a laboratory study to adjust effective parameters such as $\mathrm{pH}$, in order to control corrosion.
\end{abstract}

Keywords: Azogues city, corrosion rates, potabilization, water quality.

\section{Estimativa da tendência corrosiva e de escala no sistema de água potável}

\section{RESUMO}

A qualidade da água potável que flui em uma rede de distribuição pode fornecer características corrosivas que podem causar a degradação do material de tubos e acessórios. Esse problema pode resultar na redução da vida útil dos tubos e em um grande problema de 
saúde pública. $\mathrm{O}$ acordo entre a análise físico-química da qualidade da água e os padrões nacionais não são suficientes para confirmar o equilíbrio da qualidade da água em termos de corrosão. Para prever a corrosão da tubulação nas redes do sistema de distribuição de água, a tendência corrosiva foi avaliada utilizando os índices Langelier (LSI), Ryznar (RSI) e LarsonSkold (LRI) com base em medidas de $\mathrm{pH}$, temperatura, sólidos dissolvidos totais, alcalinidade, dureza de cálcio, sulfato e cloreto. Este estudo foi montado com 180 amostras coletadas em seis zonas da rede de distribuição, de julho a dezembro de 2017, de acordo com os métodos padronizados de análise de água potável. Os resultados obtidos indicam uma variação do LSI de -1,22 para -1,68; RSI de 9,75 a 10,52 e LRI de 0,46 a 0,77. Um modelo linear foi montado para cada índice para prever a corrosão com as condições de qualidade da água do presente estudo. Portanto, a água potável da cidade de Azogues (Equador) tem uma tendência corrosiva de significativa a severa. Os índices de corrosão foram calculados para fornecer informações úteis sobre a corrosividade da água. Esses resultados indicam a necessidade de monitorar constantemente a taxa de corrosão na rede de distribuição e realizar um estudo de laboratório para ajustar parâmetros efetivos como o pH, a fim de controlar a corrosão.

Palavras-chave: cidade de Azogues, potabilização, qualidade da água, taxas de corrosão.

\section{INTRODUCTION}

Guaranteeing the availability and sustainable management of drinking water in compliance with regulatory requirements will increase consumer confidence (Omaka et al., 2015; Sorlini et al., 2017; Collivignarelli, 2017). Drinking water causes corrosion in the pipes used for transport (Gholizadeh et al., 2017). Iron pipes that undergo a corrosion process could have a great impact on the water quality distributed in the supply network (Yang et al., 2012). The corrosion process in the pipes is related to several factors, such as the pipe material, water quality and hydraulic conditions (García-Avila et al., 2018). The effect of the different water quality parameters including $\mathrm{pH}$, residual chlorine, total organic carbon, conductivity, dissolved oxygen, hardness and alkalinity influences corrosion and the formation of scale inside the metallic pipe (Cui et al., 2016). Vazdirvanidis et al. (2016) noted that the accelerated corrosion of parts of a water pump was probably caused by the presence of sulfates, sulfides and chlorides that caused a severe chemical attack on the various metallic components of the pump. Drinking water is commonly corrosive at a $\mathrm{pH}$ of 6.5 to 7.5 and with a low alkalinity. The corrosion potential of iron is affected by sulfate and chloride concentrations, which is why, as a consequence, chemical and physical differences are considered to alter water stability (Jazdzewska et al., 2016). Bigoni et al. (2014) indicated that the turbidity and iron concentration increase the corrosion of the pipes in the drinking water distribution network in a rural hospital in Peru. Corrosion of pipes and fittings that transport potable water is becoming a problem due to the high costs of repair and replacement (Liu et al., 2017). This means that it is important to know the physical and chemical characteristics of drinking water to determine the probable existence of corrosion using the Langelier saturation index (LSI), Ryznar stability index (RSI), the Larson-Skold index (LRI) (Achari et al., 2017).

Based on the LSI, 71\% of the waters of the city of Shiraz, Iran is causing incrustation. Based on the RSI, all the zones lacked the characteristic of formation of incrustations' According to the LRI, 29\% of the city have formations of inlays (Tavanpour et al., 2016). Considering the economic cost and the health risks related to incrustation and corrosion; the corrosive or fouling tendency can be analyzed using the indirect methods shown in Table 1. The equations of this table have been used to calculate the LSI (Liang et al., 2013; Alsaqqar et al., 2014; Choi et al., 2015; Vazdirvanidis et al., 2016; Gholizadeh et al., 2017); the RSI (Alsaqqar et al., 2014; Vazdirvanidis et al., 2016; Achari et al., 2017); and the LRI (Mirzabeygi 
et al., 2017; Peng et al., 2013; Alsaqqar et al., 2014; Zhang et al., 2014).

Taking into account the corrosion problems caused in drinking water pipes and the lack of studies on the drinking water distribution network of the city of Azogues, Ecuador, this research was carried out to determine the corrosion/incrustations in the pipes of the different zones. The results provided information on the chemical behavior of inorganic contaminants in water and its influence on drinking water quality.

\section{MATERIALS AND METHODS}

\subsection{Description of the study area}

The drinking water distribution network on which this study was conducted is located in the city of Azogues, which is located in the southern part of the Ecuadorian Republic. Its geographical coordinates are: latitude $2^{\circ} 44^{\prime} 22^{\prime \prime} \mathrm{S}$, longitude: 78 $50^{\prime} 54^{\prime \prime}$, and cover approximately $1200 \mathrm{~km}^{2}$. The average altitude of the town is 2518 meters above sea level. The city has a population of 70,064 inhabitants. Its average temperature is $17^{\circ} \mathrm{C}$; about 42,071 inhabitants receive water from the public network. There are no relevant studies on the corrosion that water can cause in the pipes and fittings of both the public and private networks. Figure 1 shows the location of the network supply, which is made up of pipes with diameters between 315 and $32 \mathrm{~mm}$. The total length of the supply line is $218,105 \mathrm{~m}$. A number of 288 valves have been installed. there are 26 reserves, distributed in six zones. Ten of the reserves have a capacity between 250 and $1000 \mathrm{~m}^{3}$. The altimetric variation of whole network is 2390-2823 meters above sea level.
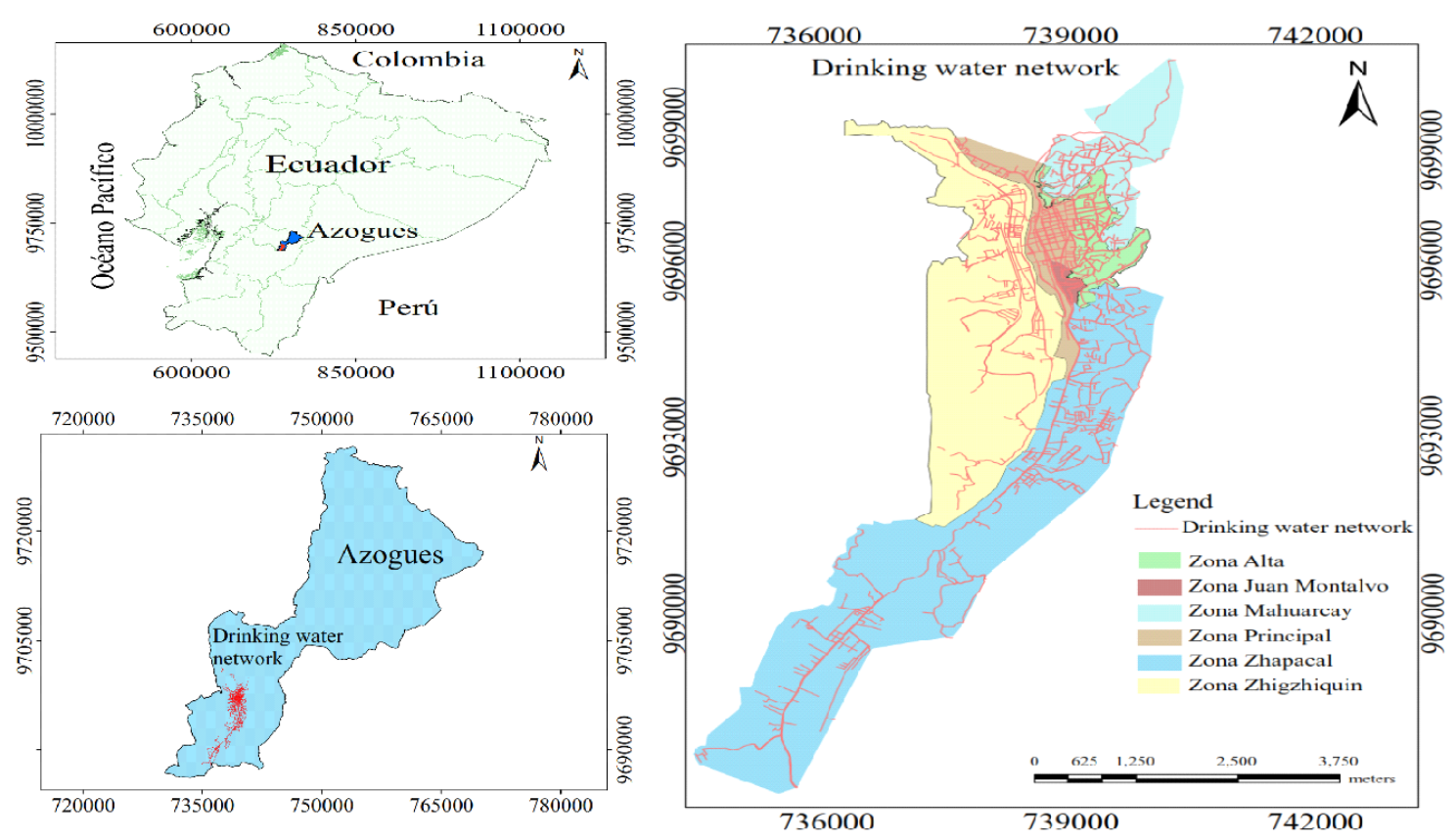

Figure 1. Location of the study area.

\subsection{Sampling and analysis of water}

To examine the conditions of corrosion and scale formation in the water distribution network of Azogues, 30 samples were taken monthly. A total of 180 drinking water samples were taken over six months at 30 sampling points; the sampling points were located in the drinking water distribution network taking into account the length of the distribution network, the location of the reserve tanks and the number of users present in each of the six zones. The sampling and analyses were carried out from July to December. All the samples were collected in polyethylene 1-liter containers complying with the necessary requirements to not alter the

\section{IPABH}


samples for later analysis. The samples were obtained from the faucets in kitchens and bathrooms of homes, commercial places such as restaurants, workshops, washing cars, shops, etc., as well as from distribution tanks. The samples were maintained at $4{ }^{\circ} \mathrm{C}$ and were transported on the same day for analysis to the laboratory of the city's municipal drinking water company. The tests on all water samples were analyzed according to the Standard Methods for the examination of water and wastewater (Apha et al., 2012). The calcium hardness and alkalinity were measured by the titration method; the concentration of hydrogen ions $(\mathrm{pH})$, total dissolved solids (TDS) and temperature were measured with the Hach Multiparameter HQ 40d; chloride and sulfate were determined with the HACH DR 2500 Spectrophotometer and compared with national standards. The $\mathrm{pH}$, TDS and temperature were determined in site.

\subsection{Determination of corrosion and scaling trend in drinking water}

The LSI, RSI and LRI were calculated using the corresponding equations in Table 1 . These indices allow the evaluation of the corrosion potential of the pipeline for each point of the network once the physical-chemical analysis has been realized (Bigoni et al., 2014).

Table 1. Description of corrosion indexes used in this study.

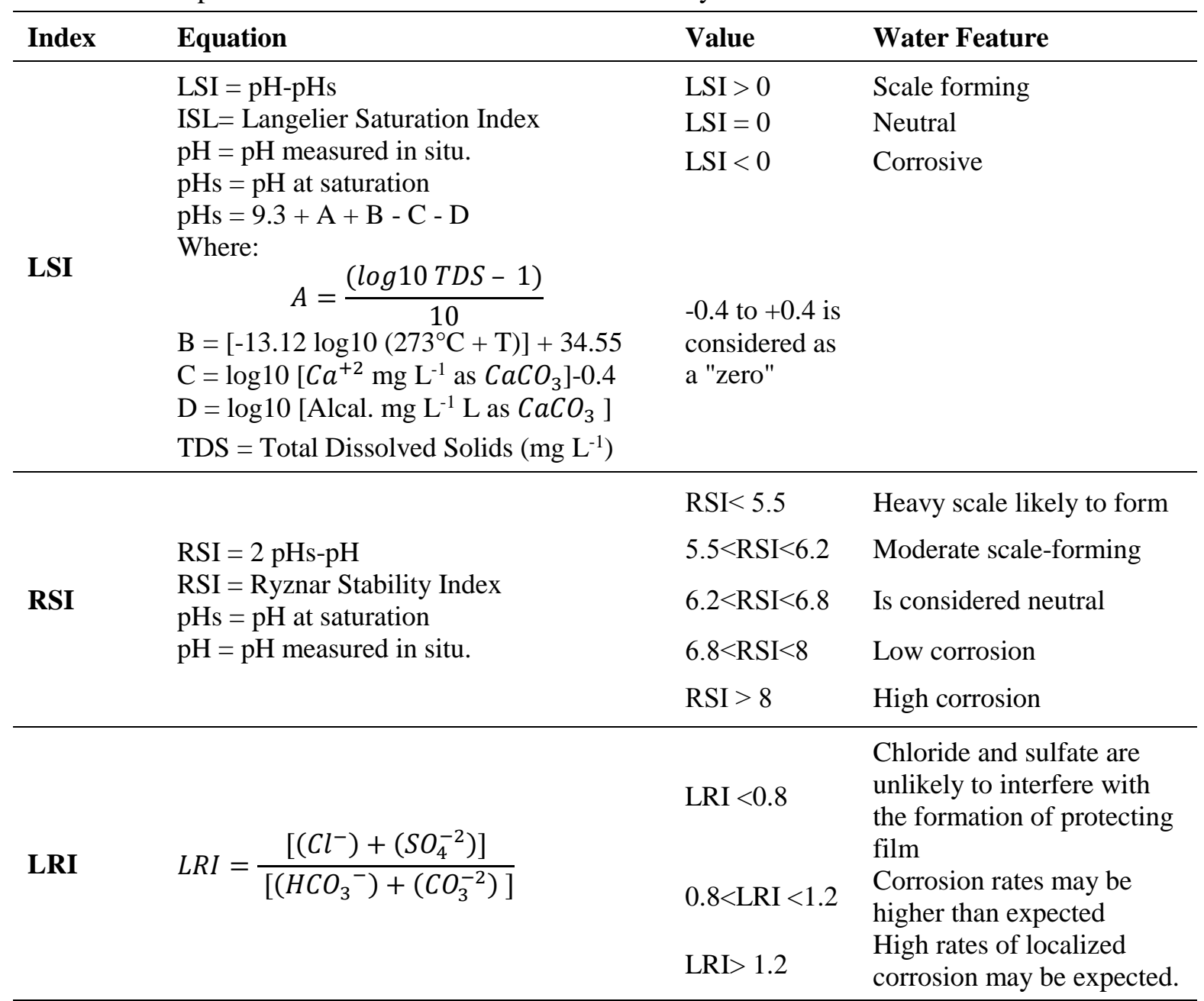

Source: Alsaqqar et al. (2014); Tavanpour et al. (2016); Mirzabeygi et al. (2017). 


\section{RESULTS AND DISCUSSION}

\subsection{Physical and chemical characteristics}

Table 2 shows the average values of temperature, $\mathrm{pH}$, total dissolved solids (TDS), the calcium hardness, alkalinity, chlorides, sulfates and free chlorine of the 180 samples collected at the 30 sites monitored over six months. Figure 2 shows the variation of the physical-chemical parameters of drinking water obtained at each of the sampling points.

When analyzing the $\mathrm{pH}$ values of both Table 2 and Figure 2, conditions observed are almost neutral at each sampling point and during all the months analyzed. In terms of quality of drinking water according to the Ecuadorian standard, the recommended established value is a minimum $\mathrm{pH}$ of 6.5 and a maximum of 8.5. While the waters evaluated are within the acceptable range with values between 6.87 and 7.75 , certain samples presented a $\mathrm{pH}$ less than 7 and were taken in the month of July. This slightly acidic condition can accelerate corrosive processes; this $\mathrm{pH}$ record is due to a contribution from natural processes. For its part, the temperature of water presented values near the ambient temperature for all samples; the temperature varied between 12.4 and $24.8^{\circ} \mathrm{C}$. The low temperatures that mostly correspond to the months of July, August and September indicate that there is a tendency to corrosion; there are no high temperatures that may cause the precipitation of calcium carbonate, which can cause scale in the pipes and therefore decrease the corrosion. Considering the average values of Figure 2 , it can be observed that the temperature values varies according the month, so the lowest temperatures are presented in the months of July and August, while the highest temperatures are presented in the months of October, November and December.

To determine the corrosive or scaling character of the water, it is also important to know the concentration of total dissolved solids (TDS). This parameter in the first instance provides an indicator of the quality of drinking water. Hence, when compared to the maximum permissible value of the Ecuadorian standard equivalent to $1000 \mathrm{mg} \mathrm{L}^{-1}$, it can be observed that the water distributed in Azogues presents values between 43.1 and $108.0 \mathrm{mg} \mathrm{L}^{-1}$, well below the established maximums. Even in spite of the low concentrations of TDS, it is important to note that the concentration of total dissolved solids in aqueous solutions is directly proportional to the conductivity, and its increase can favor the corrosive tendency.

When examining the values of drinking water hardness presented in Figure 2, according to the classification, it is observed that this water presents slightly hard values, which is especially related to low concentrations of calcium. This parameter is also an indicator of the quality of drinking water. Hence, when compared with the maximum permissible value of the Ecuadorian standard equivalent to $300 \mathrm{mg} \mathrm{L}^{-1}$, it can be observed that drinking water for the present study has values between 32.1 and $79.1 \mathrm{mg} \mathrm{L}^{-1}$, which are well below the established maximums. Waters with low hardness are considered aggressive, causing deterioration and corrosion in supply networks. This fact, together with the low $\mathrm{pH}$ presented at certain points, can generate a corrosive effect on the part of these waters.

Figure 2 shows that the alkalinity during the months of July to September has lower values compared to the months of October to December. This is due to the fact that during the months of July and August there are generally fewer rains that cause a decrease in alkalinity; in general there is a corrosive tendency caused by low alkalinity of water, which is at values lower than $76 \mathrm{mg} \mathrm{L}^{-1}$ as calcium carbonate. The Ecuadorian norm for concentrations of sulfate and chloride ions in drinking water establish maximum permissible values of $200 \mathrm{mg} \mathrm{L}^{-1}, 250 \mathrm{mg} \mathrm{L}^{-1}$, respectively. The average values found in the drinking water in the present study were $5.65 \mathrm{mg} \mathrm{L}^{-1}$ and $18.12 \mathrm{mg} \mathrm{L}^{-1}$, which are well below the established norm. Sulfate ions and chlorides are components of natural waters, which is why the presence of these ions and their low concentrations is justified. 
Table 2. Average values of the analysis of water collected in the sampling sites.

\begin{tabular}{|c|c|c|c|c|c|c|c|}
\hline $\begin{array}{c}\mathbf{N}^{\circ} \\
\text { Sample }\end{array}$ & pH & $\begin{array}{c}\text { Temperature } \\
{ }^{\circ} \mathrm{C}\end{array}$ & $\begin{array}{c}\text { TDS } \\
\text { mg } L^{-1}\end{array}$ & $\begin{array}{c}\text { Calcium } \\
\mathrm{mg} \mathrm{L}^{-1} \text { as } \\
\mathrm{CaCO}_{3}\end{array}$ & $\begin{array}{c}\text { Alkalinity } \\
\mathrm{mg} \mathrm{L}^{-1} \text { as } \\
\mathrm{CaCO}_{3}\end{array}$ & $\begin{array}{l}\text { Sulphate } \\
\text { mg L }^{-1}\end{array}$ & $\begin{array}{c}\text { Chloride } \\
\text { mg L }^{-1}\end{array}$ \\
\hline 1 & $7.42 \pm 0.07$ & $17.66 \pm 0.6$ & $81.17 \pm 7.02$ & $20.40 \pm 1.91$ & $46.83 \pm 6.30$ & $22.33 \pm 2.73$ & $5.30 \pm 0.47$ \\
\hline 2 & $7.38 \pm 0.08$ & $18.96 \pm 0.4$ & $82.17 \pm 5.33$ & $20.87 \pm 1.49$ & $50.00 \pm 6.32$ & $21.00 \pm 2.45$ & $5.58 \pm 0.55$ \\
\hline 3 & $7.2+0.06$ & $16.72 \pm 1.0$ & $63.67 \pm 4.54$ & $20.87 \pm 2.01$ & $51.33 \pm 5.33$ & $19.17 \pm 1.96$ & $5.33 \pm 0.59$ \\
\hline 4 & $7.17 \pm 0.05$ & $19.44 \pm 0.7$ & $80.67 \pm 7.82$ & $23.13 \pm 1.79$ & $48.67 \pm 5.81$ & $23.00 \pm 2.27$ & $5.22 \pm 0.54$ \\
\hline 5 & $7.41 \pm 0.12$ & $18.02 \pm 0.5$ & $71.50 \pm 6.48$ & $21.80 \pm 2.80$ & $46.67 \pm 6.27$ & $19.50 \pm 2.91$ & $5.05 \pm 0.96$ \\
\hline 6 & $7.23 \pm 0.07$ & $17.3 \pm 0.6$ & $70.50 \pm 5.16$ & $22.47 \pm 1.54$ & $52.50 \pm 5.90$ & $19.17 \pm 2.01$ & $5.12 \pm 0.57$ \\
\hline 7 & $7.2 \pm 0.06$ & $17.44 \pm 08$ & $72.33 \pm 6.01$ & $21.67 \pm 2.01$ & $52.5 \pm 6.05$ & $18.83 \pm 2.06$ & $11.58+0.6$ \\
\hline 8 & $7.18 \pm 0.06$ & $16.3 \pm 0.6$ & $72.33 \pm 4.24$ & $21.73 \pm 1.79$ & $53.67 \pm 5.65$ & $18.58 \pm 1.70$ & $4.57 \pm 1.05$ \\
\hline 9 & $7.2 \pm 0.05$ & $17.72 \pm 1.0$ & $64.50 \pm 5.91$ & $21.00 \pm 1.43$ & $49.50 \pm 5.14$ & $17.33 \pm 2.33$ & $5.38 \pm 0.71$ \\
\hline 10 & $7.22 \pm 0.05$ & $16.1 \pm 1.4$ & $66.33 \pm 4.76$ & $20.20 \pm 1.63$ & $50.50 \pm 6.04$ & $17.33 \pm 1.96$ & $5.70 \pm 0.48$ \\
\hline 11 & $7.16 \pm 0.05$ & $15.78 \pm 0.3$ & $72.67 \pm 6.50$ & $21.33 \pm 1.66$ & $51.00 \pm 4.92$ & $15.50 \pm 2.08$ & $5.58 \pm 0.97$ \\
\hline 12 & $7.26 \pm 0.05$ & $15.66 \pm 0.8$ & $68.83 \pm 4.69$ & $21.47 \pm 1.14$ & $53.67 \pm 6.06$ & $17.00 \pm 2.77$ & $4.95 \pm 0.6$ \\
\hline 13 & $7.11 \pm 0.08$ & $16.16 \pm 1.2$ & $60.00 \pm 3.66$ & $17.47 \pm 0.98$ & $40.67 \pm 2.53$ & $13.50 \pm 2.77$ & $7.27 \pm 1.56$ \\
\hline 14 & $7.25 \pm 0.10$ & $18.06 \pm 0.8$ & $70.00 \pm 5.66$ & $22.23 \pm 2.16$ & $47.00 \pm 6.47$ & $21.00 \pm 2.39$ & $5.30 \pm 0.41$ \\
\hline 15 & $7.3 \pm 0.08$ & $16.36 \pm 0.4$ & $70.33 \pm 6.54$ & $21.57 \pm 1.48$ & $48.67 \pm 4.98$ & $20.17 \pm 1.66$ & $5.67 \pm 0.46$ \\
\hline 16 & $7.17 \pm 0.06$ & $18.2 \pm 1.3$ & $72.67 \pm 7.29$ & $21.33 \pm 1.35$ & $45.67 \pm 4.90$ & $21.17 \pm 2.24$ & $5.22 \pm 0.4$ \\
\hline 17 & $7.21 \pm 0.07$ & $17.64 \pm 0.2$ & $69.83 \pm 5.55$ & $20.60 \pm 1.39$ & $46.00 \pm 4.50$ & $18.83 \pm 1.89$ & $5.62 \pm 0.74$ \\
\hline 18 & $7.24 \pm 0.06$ & $17.8 \pm 0.7$ & $68.67 \pm 6.99$ & $22.00 \pm 1.78$ & $48.83 \pm 5.08$ & $19.00 \pm 2.82$ & $5.58 \pm 0.4$ \\
\hline 19 & $7.23 \pm 0.09$ & $17.76 \pm 0.6$ & $71.00 \pm 6.04$ & $21.87 \pm 1.90$ & $47.50 \pm 5.66$ & $19.67 \pm 2.38$ & $5.58 \pm 0.65$ \\
\hline 20 & $7.18 \pm 0.06$ & $17.52 \pm 1.2$ & $69.67 \pm 7.22$ & $21.20 \pm 1.48$ & $46.52 \pm 4.27$ & $17.67 \pm 2.69$ & $5.57 \pm 0.61$ \\
\hline 21 & $7.22 \pm 0.06$ & $18.7 \pm 0.4$ & $58.17 \pm 2.33$ & $17.47 \pm 1.0$ & $40.82 \pm 1.87$ & $12.50 \pm 2.79$ & $6.63 \pm 1.03$ \\
\hline 22 & $7.24 \pm 0.04$ & $17.3 \pm 0.5$ & $63.50 \pm 4.92$ & $20.13 \pm 1.54$ & $46.50 \pm 4.15$ & $18.50 \pm 2.17$ & $5.72 \pm 0.80$ \\
\hline 23 & $7.24 \pm 0.09$ & $17.62 \pm 0.7$ & $68.17 \pm 5.13$ & $21.33 \pm 1.78$ & $49.17 \pm 5.24$ & $19.50 \pm 2.11$ & $5.47 \pm 0.47$ \\
\hline 24 & $7.26 \pm 0.07$ & $17.22 \pm 1.1$ & $66.83 \pm 6.77$ & $21.07 \pm 1.73$ & $47.50 \pm 2.96$ & $17.50 \pm 2.62$ & $5.80 \pm 0.58$ \\
\hline 25 & $7.2 \pm 0.05$ & $17.1 \pm 0.7$ & $64.33 \pm 3.8$ & $20.07 \pm 1.56$ & $46.33 \pm 3.48$ & $17.00 \pm 2.28$ & $5.30 \pm 0.82$ \\
\hline 26 & $7.26 \pm 0.09$ & $18.1 \pm 0.6$ & $67.83 \pm 5.15$ & $20.67 \pm 1.37$ & $48.83 \pm 4.43$ & $16.33 \pm 2.33$ & $5.88 \pm 0.74$ \\
\hline 27 & $7.28 \pm 0.07$ & $16.24 \pm 1.1$ & $65.17 \pm 6.99$ & $20.13 \pm 1.54$ & $47.67 \pm 4.72$ & $15.83 \pm 2.21$ & $6.03 \pm 0.68$ \\
\hline 28 & $7.31 \pm 0.06$ & $17.16 \pm 1.2$ & $67.83 \pm 5.70$ & $20.2 \pm 1.51$ & $51.33 \pm 4.72$ & $17.33 \pm 2.17$ & $6.00 \pm 0.86$ \\
\hline 29 & $7.26 \pm 0.05$ & $18.56 \pm 0.8$ & $72.50 \pm 6.84$ & $20.13 \pm 1.43$ & $49.00 \pm 5.49$ & $16.17 \pm 2.70$ & $5.93 \pm 0.67$ \\
\hline 30 & $7.27 \pm 0.06$ & $17.26 \pm 1.2$ & $59.83 \pm 2.64$ & $17.33 \pm 0.91$ & $40.00 \pm 2.54$ & $14.00 \pm 3.2$ & $5.97 \pm 1.22$ \\
\hline
\end{tabular}



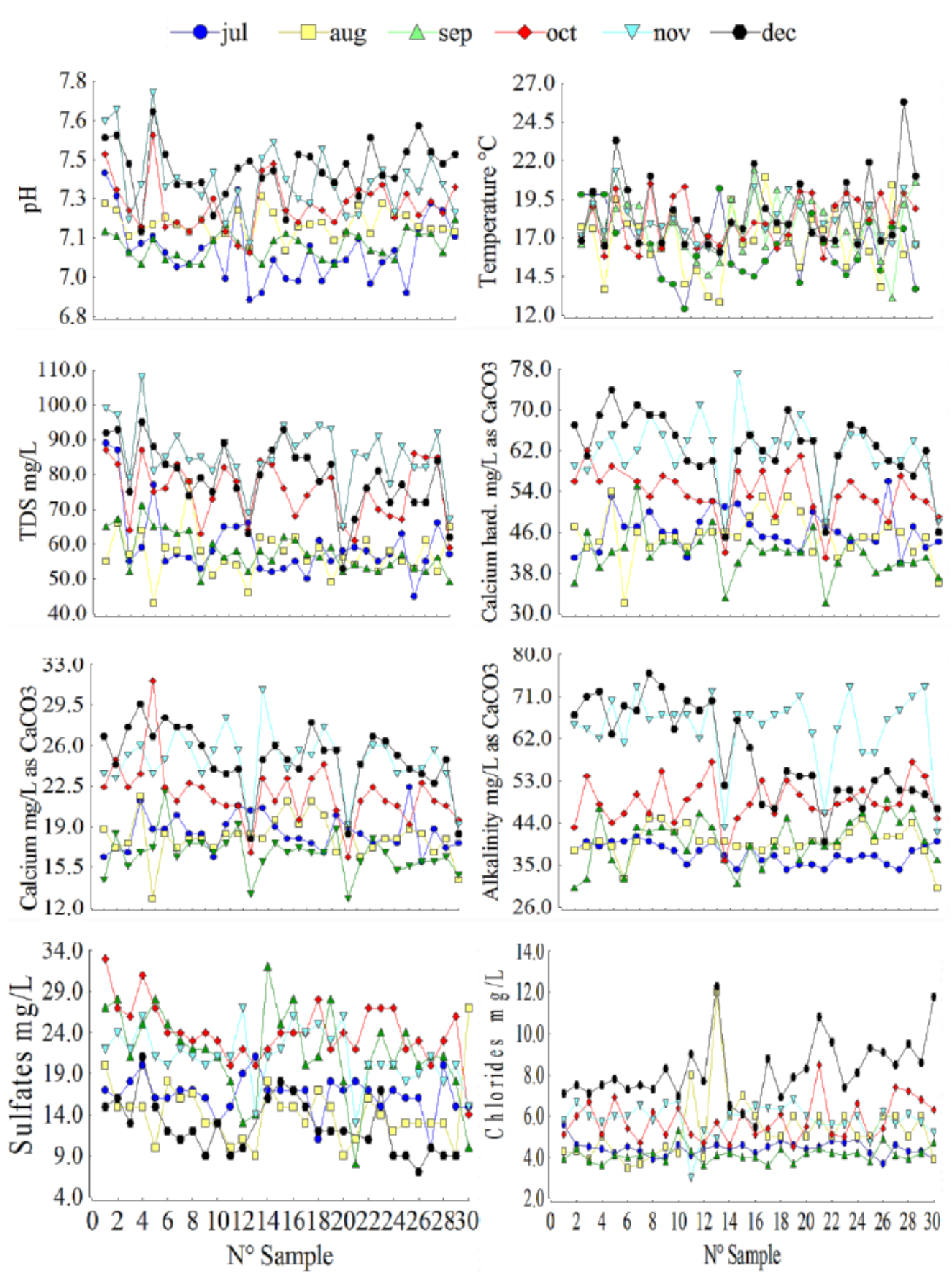

Figure 2. Variation of $\mathrm{pH}$, temperature, TDS, calcium, alkalinity, sulfates and chlorides of drinking water in the distribution network sampling points.

\subsection{Corrosion monitoring}

Table 3 presents the mean values of the indices obtained by zones of the supply network. The table shows that the values of the indices are similar in each of the zones. All values obtained for the LSI are negative, with an average value of 1.39 (Table 3 and Figure 3), indicating that the water that is distributed in all zones of Azogues is corrosive, considering that at more negative values there is greater corrosivity. The values in Table 3 show that the zones Zhigzhiquin and Zhapacal (2390-2500 altitude meters above sea level) have less negative values with respect to the Mahuarcay zone (altitude 2700-2823 meters above sea level); this could be due to the temperature variation, which in turn affects the $\mathrm{pH}$.

The values obtained with the RSI turned out to be greater than nine, indicating that the water that is distributed in Azogues is very corrosive. It can be seen that the LRI average value

\section{IPABH}


of 10.07 shows a slightly to moderately corrosive character of the drinking water distributed in Azogues. Meanwhile, average LRI values of 0.58 were obtained, which does not conform with the strongly corrosive character determined by the Langelier and Ryznar models. This difference is because the Larson-Skold relationship is based on the corrosive influence of the chloride, sulfate and bicarbonate ion, not considering other physicochemical factors such as $\mathrm{pH}$, temperature, total dissolved solids, alkalinity and calcium.

Table 3. Average values of corrosion indexes by zones.

\begin{tabular}{lccc}
\hline Zone & LSI & RSI & LRI \\
\hline Alta & -1.40 & 10.03 & 0.52 \\
Mahuarcay & -1.58 & 10.38 & 0.53 \\
Media & -1.4 & 10.03 & 0.67 \\
Zhigzhiquin & -1.31 & 9.94 & 0.63 \\
Principal & -1.43 & 10.09 & 0.54 \\
Zhapacal & -1.34 & 9.93 & 0.60 \\
\hline Average & $\mathbf{- 1 . 3 9}$ & $\mathbf{1 0 . 0 7}$ & $\mathbf{0 . 5 8}$ \\
p & $<0.0001$ & $<0.0001$ & $<0.0001$ \\
\hline
\end{tabular}

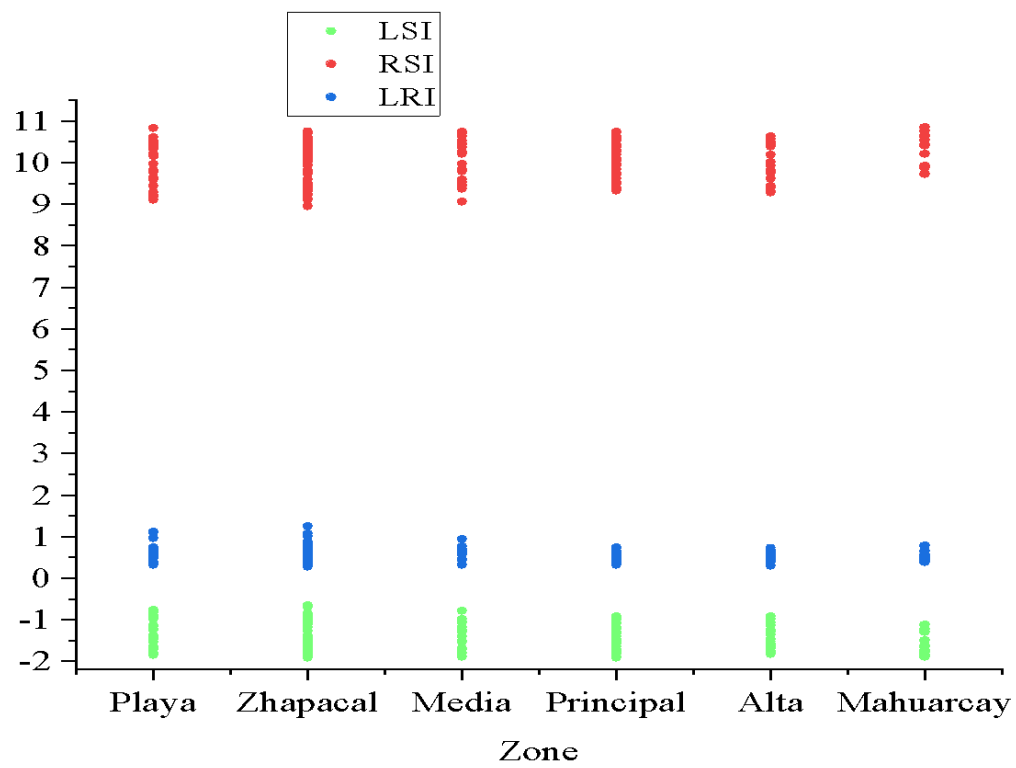

Figure 3. Variation of corrosion indexes in the different zones.

The results obtained by several authors are presented in Table 4 . When compared with the results obtained in this study, we can observe a similarity to the results obtained by Alimoradi et al. (2018) and Khorsandi et al. (2015). These waters are highly corrosive based on the LSI, RSI and LRI; but they have no tendency to form coatings of calcium carbonate precipitates, due to the low alkalinity and hardness.

Table 4. Average values of LSI, RSI, LRI obtained by several authors.

\begin{tabular}{lccc}
\hline Authors & LSI & RSI & LRI \\
\hline Abbasnia et al. (2018) & 0.5 & 6.76 & 2.71 \\
Yousefi et al. (2018) & 1.15 & 6.92 & 0.85 \\
Alimoradi et al. (2018) & -1.31 & 9.73 & 0.24 \\
Khorsandi et al. (2015) & -1.94 & 12.05 & 0.68 \\
Tavanpour et al. (2016) & 0.08 & 7.15 & 1.1 \\
\hline
\end{tabular}


Figure 4 shows the variation of corrosion indexes with physical-chemical parameters. $\mathrm{pH}$ is one of the main factors that influence the corrosion process (Cui et al., 2016). In Table 2 and Figure 2, it can be observed that the $\mathrm{pH}$ varied between 6.87 and 7.75, with an average of 7.24. In Figure 4(a) it can be seen that the LSI increases with increasing pH; meanwhile, the RSI decreased with the increase of $\mathrm{pH}$. Therefore, corrosion increases with the decrease in $\mathrm{pH}$. Another factor that alters the corrosion process is temperature; increase in temperature can cause the precipitation of calcium carbonate, which can cause encrustation in the pipes and therefore reduce corrosion. In Table 2 and Figure 2, it can be observed that the temperature varied between 12.4 and $24.8^{\circ} \mathrm{C}$, with an average of $17.6^{\circ} \mathrm{C}$. In Figure $4(\mathrm{~b})$, it can be seen that the LSI increased with the temperature increase; meanwhile, the RSI decreased with temperature.

The conventional potabilization process does not affect the dissolved content of treated water. The effect of TDS content on the corrosivity of water is a complex issue; some substances such as carbonate and bicarbonate reduce corrosion, while chloride and sulfate ions notably accelerate corrosion (Alsaqqar et al., 2014). From the data registered in Table 2 and Figure 2, the TDS concentration fluctuated between 43.1 and $108.0 \mathrm{mg} \mathrm{L}^{-1}$ with an average of $69.29 \mathrm{mg} \mathrm{L}^{-1}$. In Figure 4(c) it can be seen that the LSI increased with the increase of the TDS. Meanwhile, the RSI was reduced with the increase of TDS; therefore the corrosion increases with the decrease of TDS. Calcium is the second most frequent component in most surface waters and is generally among the three or four most frequent ions in groundwater. The increase $\mathrm{Ca}^{2+}$ concentration decreases water corrosivity (Mirzabeygi et al., 2017), since $\mathrm{Ca}^{2+}$ is important for the formation of a passivation film on the surface of the pipe, decreasing corrosion. From the data recorded in Table 2 and Figure 2, the $\mathrm{Ca}^{2+}$ concentration varied between 12.8 and $31.6 \mathrm{mg} \mathrm{L}^{-1}$, with an average of $20.8 \mathrm{mg} \mathrm{L}^{-1}$. In Figure 4(d), it can be seen that the LSI increased with the calcium increase; the RSI decreased with the calcium increase. The slightly low calcium values in this study influenced the presence of drinking water corrosion.

In water treatment plants, alkalinity is required in the coagulation process for the reaction of alum with water; lime can be added if natural alkalinity is not sufficient for this reaction. Water corrosivity increases as alkalinity decreases (Peng et al., 2013, Choi et al., 2015). According to data obtained from the water analysis, the variation in alkalinity ranged between 30.00 and $76.00 \mathrm{mg} \mathrm{L}^{-1}$, with an average of $48.42 \mathrm{mg} \mathrm{L}^{-1}$ as $\mathrm{CaCO}_{3}$, as shown in Table 2 and Figure 2. In Figure 4(e) it can be seen that the LSI increased with the increase in alkalinity; meanwhile, the RSI decreased with the increase in alkalinity. The somewhat low concentrations of alkalinity that have been obtained in this study favor the solubility of $\mathrm{CO}_{2}$, increasing the drinking water corrosivity; it can also be observed that alkalinity does not have a great relationship with the LRI.

The chloride and sulfate ions drastically reduce corrosion resistance (Vazdirvanidis et al., 2016; Yang et al., 2012). Steel is easily susceptible to pitting corrosion in solutions containing aerated chloride with $\mathrm{pH}$ in a wide range $(4-12.5)$ at room temperature (Wang et al., 2015). According to data obtained from the water analysis, the chloride ion concentration fluctuated between 1.30 and $12.30 \mathrm{mg} \mathrm{L}^{-1}$, with an average of $5.65 \mathrm{mg} \mathrm{L}^{-1}$; the sulfate varied between 3.0 and $33.0 \mathrm{mg} \mathrm{L}^{-1}$ with an average of $18.12 \mathrm{mg} \mathrm{L}^{-1}$, as shown in Table 2 and Figure 2. In Figure 4(f), it can be seen that the LRI increases with the increase of the concentration of the sulfate ion; the LRI does not show a direct relationship with the chloride ion concentration. Hence, according to the LRI values obtained in this study, there is a slight corrosion of drinking water.

A box plot was made using the monthly results for each of the indices. For the LSI, Figure 5(a) shows that during the first three months of monitoring (July-September) values are observed between -1.40 and -2.00 , indicating a strong corrosion. This is due to the fact that in these months the ambient temperature and therefore of the water is low with respect to that registered during the year. In the same way, the alkalinity and $\mathrm{pH}$ were slightly low from July

\section{IPABH}

Rev. Ambient. Água vol. 13 n. 5, e2237 - Taubaté 2018 
to September, which increased the corrosion. From October to December, a decrease of -1.40 to -0.80 can be observed in the LSI, generating a less corrosive tendency than during the three previous months.

Analyzing the box plot for the RSI, Figure 5(b) shows that during the first three months of sampling (July-September) values between 10.00 and 11.00 are observed, due to a significant decrease in terms of the temperature, $\mathrm{pH}$ and alkalinity. During the following three months a decrease in the index of 10.00 to 9.00 can be observed, decreasing this index, but retaining its severe corrosive character.
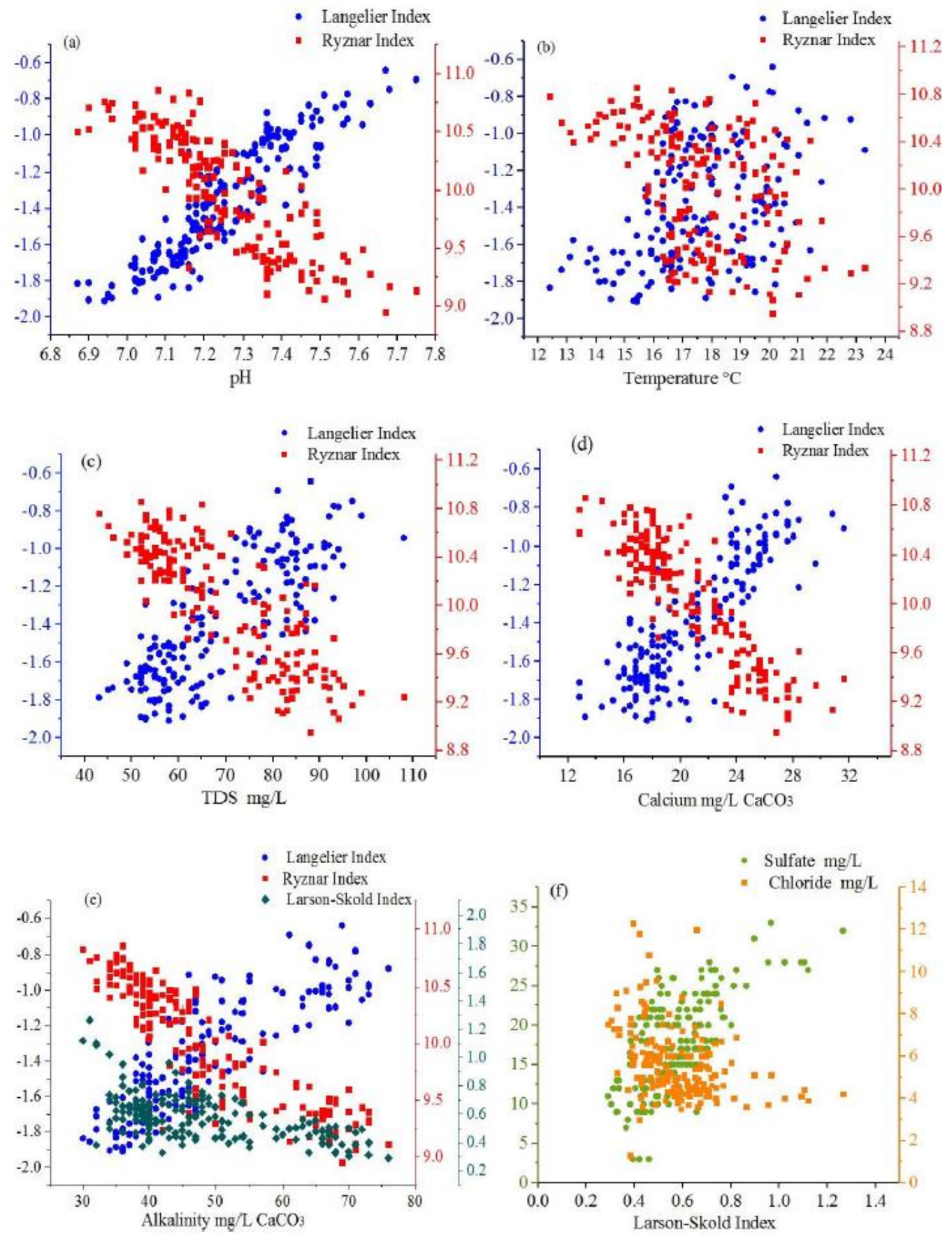

Figure 4. Variation of corrosion indexes with physical-chemical parameters. (a) $\mathrm{pH}$ relationship with LSI and RSI; (b) temperature relationship with LSI and RSI; (c) TDS relationship with LSI and RSI; (d) calcium relationship with LSI and RSI; (e) alkalinity relationship with LSI, RSI and LRI; (f) LRI relationship with sulfates and chlorides. 
In Figure 5(c), we can observe a constant trend regarding the LRI; the values calculated and analyzed during July - December, are between the range of 0.29 to 1.26 , with an average value of 0.56 , presenting a slight corrosion, with a slightly corrosive character, which indicates that there is little amount of chloride and sulfate ions that can cause corrosivity.
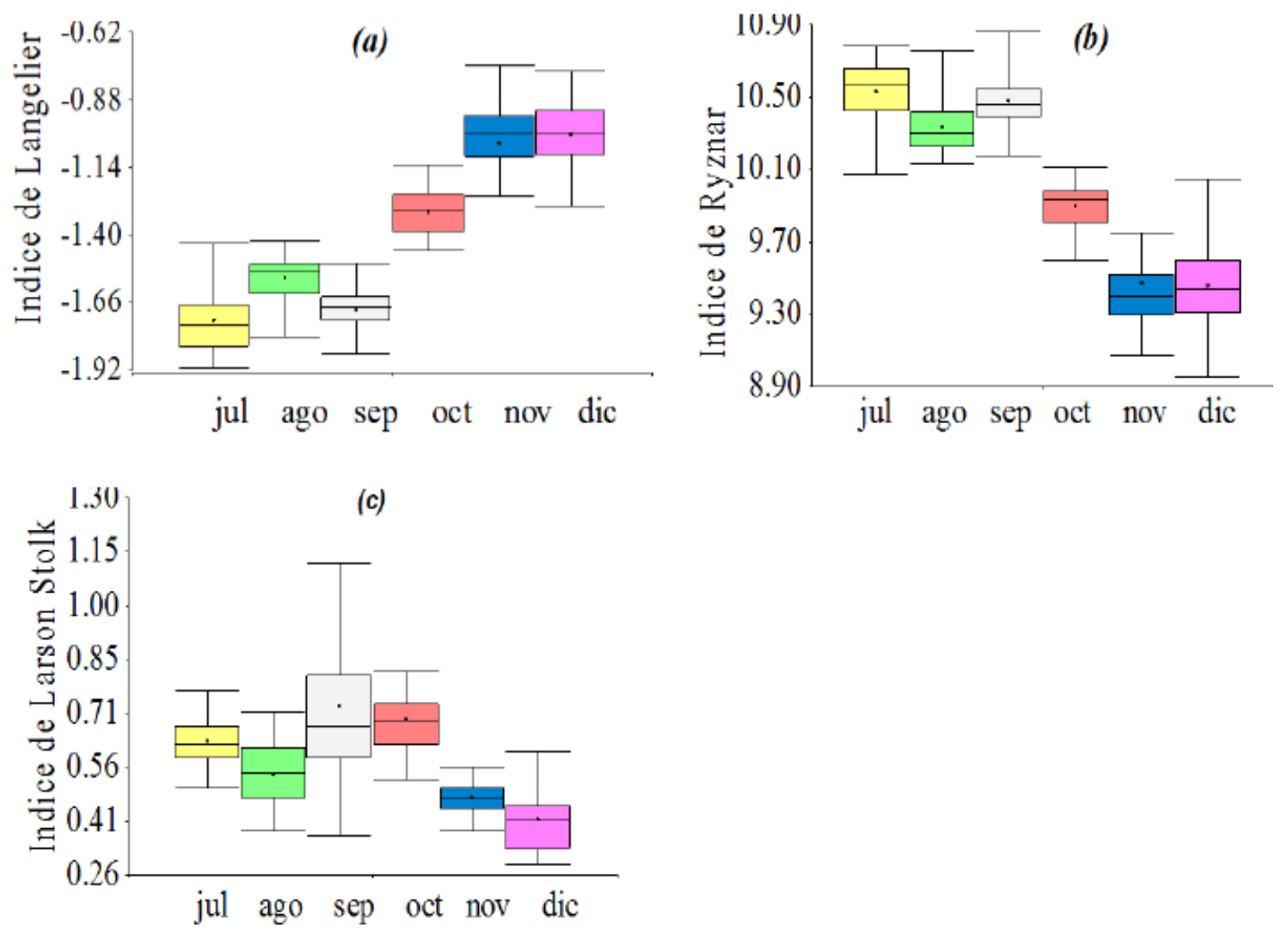

Figure 5. Variation of corrosion indexes over time. (a) Variation of LSI with months, (b) Variation of RSI with months, (c) Variation of LRI with months.

\subsection{Linear model for corrosion indexes}

To facilitate the calculation of corrosion in the drinking water distribution network in Azogues, a mathematical model was obtained for each of the corrosion indexes analyzed in this study. The multiple regression technique was applied using Infostat software, based on data of $\mathrm{pH}$, temperature, SDT, alkalinity, calcium, sulfates and chlorides, obtained from drinking water sampling and analysis. The results of the multiple regression for LSI are presented in Table 5.

Table 5. Regression coefficients and statistical data associated with the LSI model.

\begin{tabular}{lcccccccc}
\hline Coef & Est. & E.E. & LI (95\%) & LS (95\%) & T & P-Value & CpMallows & VIF \\
\hline Const & -9.84 & 0.06 & -9.96 & -9.71 & -155.32 & $<0.0001$ & & \\
PH & 1.01 & 0.01 & 0.99 & 1.03 & 106.29 & $<0.0001$ & 11236.03 & 1.96 \\
T & 0.02 & $6.60 \mathrm{E}-04$ & 0.02 & 0.02 & 28.91 & $<0.0001$ & 836.03 & 1.36 \\
SDT & $-4.30 \mathrm{E}-04$ & $1.60 \mathrm{E}-04$ & $-7.50 \mathrm{E}-04$ & $-1.20 \mathrm{E}-04$ & -2.69 & 0,008 & 12.18 & 3.91 \\
Calcium & 0.02 & $5.50 \mathrm{E}-04$ & 0.02 & 0.02 & 38.61 & $<0.0001$ & 1487.2 & 3.42 \\
Alkalinity & 0.01 & $1.80 \mathrm{E}-04$ & 0.01 & 0.01 & 44.71 & $<0.0001$ & 1992.51 & 3.49 \\
\hline
\end{tabular}

It can be observed that the $\mathrm{pH}$, temperature, TDS, calcium and alkalinity showed a value $\mathrm{p}<0.05$, there being a significant linear relationship with the LSI. The model obtained for the LSI is (Equation 1):

$$
L S I=-9.95+1.03 p H+0.02 T-0.00049 S D T+0.02 \text { Calcium }+0.01 \text { Alkalinity }
$$

\section{IPABH}


The equation is useful to calculate the LSI knowing the values of $\mathrm{pH}$, temperature in ${ }^{\circ} \mathrm{C}$, SDT in $\mathrm{mg} / \mathrm{L}$, calcium hardness in and alkalinity in $\mathrm{mg} / \mathrm{L}$ as $\mathrm{CaCO}_{3}$.

The results of the multiple regression for RSI are presented in Table 6. It can also be noted that the $\mathrm{pH}, \mathrm{T}, \mathrm{SDT}$, calcium and alkalinity showed a value $\mathrm{p}<0.05$, there being also a significant linear relationship with the RSI. The model obtained for the RSI is (Equation 2):

$R S I=19.93-1.06 p H-0.04 T+0.00096 S D T-0.04$ Calcium -0.02 Alkalinity

Table 6. Regression coefficients and statistical data associated with the RSI model.

\begin{tabular}{lcccccccc}
\hline Coef & Est. & E.E. & LI (95\%) & LS (95\%) & T & P-Value & CpMallows & VIF \\
\hline Const & 19.7 & 0.12 & 13.67 & 19.95 & 157.76 & $<0.0001$ & & \\
PH & -1.02 & 0.02 & -1.06 & -0.99 & -54.61 & $<0.0001$ & 2969.87 & 1.96 \\
T & -0.04 & $1.30 \mathrm{E}-03$ & -0.04 & -0.04 & -29.55 & $<0.0001$ & 873.33 & 1.36 \\
SDT & $8.40 \mathrm{E}-04$ & $3.20 \mathrm{E}-04$ & $2.10 \mathrm{E}-04$ & $1.50 \mathrm{E}-03$ & 2.64 & 0.0091 & 11.94 & 3.91 \\
Calcium & -0.04 & $1.10 \mathrm{E}-03$ & -0.04 & -0.04 & -39.07 & $<0.0001$ & 1522.9 & 3.42 \\
Alkalinity & -0.02 & $3.60 \mathrm{E}-04$ & -0.02 & -0.02 & -45.06 & $<0.0001$ & 2023.09 & 3.49 \\
\hline
\end{tabular}

\section{CONCLUSIONS}

Although the temperature values, total dissolved solids, alkalinity, calcium hardness, sulfate and chloride obtained in this study were admissible based on Ecuadorian regulations, the average values of the corrosion indexes obtained in this study indicated a significant corrosive tendency. The results obtained were: LSI: -1.39 ; RSI: 10.02 and LRI: 0.58 . These indicated a significant corrosive tendency of the drinking water distributed in Azogues. The most critical parameter analyzed for the LSI and RSI is $\mathrm{pH}$, as well as the low alkalinity and low hardness; while, for the Larson-Stolk index, the most critical parameter is sulfate. It can be concluded that an understanding of the chemical composition of drinking water is vital for predicting the materials behavior that are in contact with drinking water. The corrosion calculation caused by the water is based solely on the physical chemical parameters proposed by Langelier, Ryznar and Larson-Skold; this is not so exact, considering other factors or conditions that prevail in a typical drinking water network, such as dissolved oxygen, residual chlorine and room temperature. the supply system. This factor should be taken into account for the control and prevention of corrosion potential; adjustments in stabilization should be made at the treatment plant.

\section{ACKNOWLEDGEMENTS}

Fernando García developed this project with his own funds during his doctoral studies in Engineering and Environmental Sciences. The authors thank Eng. Xavier Ramírez, the manager of EMAPAL EP, for his support of this study. We also thank Damián Pauta and Diego Quezada, who helped with the monitoring campaign described, and Lcda Lucy Timbe for his help in translating the document.

\section{REFERENCES}

ABBASNIA, A.; ALIMOHAMMADI, M.; MAHVIA, A. H.; NABIZADEH, R.; YOUSEFI, M.; MOHAMMADI, A. A. et al. Assessment of groundwater quality and evaluation of scaling and corrosiveness potential of drinking water samples in villages of Chabahr city, Sistan and Baluchistan province in Iran. Data Brief, v. 16, p. 182-192, 2018. https://doi.org/10.1016/j.dib.2017.11.003 
ACHARI, V. S.; DEEPA, P.; AMBILI, M. S.; GEORGE, T. R. Corrosion Indices, Drinking and Irrigation Water Quality of Andhakaranazhy and Cherai Coastal Regions of Kerala. Academy of Chemistry Teachers, v. 3, n. 1, p. 10-14, 2017.

ALIMORADI, J.; NAGHIPOUR, D.; KAMANI, H. Data on corrosive water in the sources and distribution network of drinking water in north of Iran. Data Brief, v.17, p.105-118, 2018. https://doi.org/10.1016/j.dib.2017.12.057

ALSAQQAR, A.; KHUDAIR, B.; ALI, S. Evaluating Water Stability Indices from Water Treatment Plants in Baghdad City. Journal of Water Resource and Protection, v. 6, n. 14, p. 1344-1351, 2014. http://dx.doi.org/10.4236/jwarp.2014.614124

AMERICAN PUBLIC HEALTH ASSOCIATION - APHA; AMERICAN WATER WORKS ASSOCIATION - AWWA; WATER ENVIRONMENT FEDERATION - WEF. Standard Methods for examination of water and wastewater. Washington, DC, 2012.

BIGONI, R.; SORLINI, S.; COLLIVIGNARELlI, M. C.; BERBENNI, P. Drinking water quality assessment and corrosion mitigation in the hospital water supply system of Chacas village (Perú). Revista Ambiente \& Água, v. 9, n. 3, p. 379-389, 2014. http://dx.doi.org/10.4136/ambi-agua.1407

CHOI, J.; GYU, B.; HONG, S. Effects of NF treated water on corrosion of pipe distribution system and its implications to blending with conventionally treated water. Desalination, v. 360, p. 138-145, 2015. https://doi.org/10.1016/j.desal.2015.01.026

COLLIVIGNARELLI, C. Water safety: one of the primary objectives of our time. Revista Ambiente \& Água, v. 12, n. 1, p. 1-7, 2017. http://dx.doi.org/10.4136/ambi-agua.1994

CUI, Y.; LIU, S.; SMITH, K.; YU, K.; HU, H.; JIANG, W. Characterization of corrosion scale formed on stainless steel delivery pipe for reclaimed water treatment. Water Research, v. 88, p. 816-825, 2016. http://dx.doi.org/10.1016/j.watres.2015.11.021

GARCÍA-AVILA, F.; BONIFAZ-BARBA, G.; DONOSO-MOSCOSO, S.; FLORES DEL PINO, L.; RAMOS-FERNÁNDEZ, L. Dataset of copper pipes corrosion after exposure $\begin{array}{lllllll}\text { to chlorine. Data } & \text { Brief, } & \text { v. } 19, \quad \text { p. }\end{array}$ https://doi.org/10.1016/j.dib.2018.05.023

GHOLIZADEH, A.; MOKHTARI, M.; NAIMI, N.; SHIRAVANDC, B.; EHRAMPOUSHA, M. H.; MIRI, M. et al. Assessment of corrosion and scaling potential in groundwater resources; a case study of Yazd-Ardakan Plain , Iran. Groundwater for Sustainable Development, v. 5, p. 59-65, 2017. https://doi.org/10.1016/j.gsd.2017.04.002

JAZDZEWSKA, A.; DAROWICKI, K.; ORLIKOWSKI, J.; KRAKOWIAK, S.; ZAKOWSKI, K.; GRUSZKA, M. et al. Critical analysis of laboratory measurements and monitoring system of water-pipe network corrosion-case study. Case Studies in Construction Materials, v.4, p. 102-107, 2016. https://doi.org/10.1016/j.cscm.2016.01.004

KHORSANDI, H.; MOHAMMADI, A.; KARIMZADEH, S.; KHORSANDI, J. Evaluation of corrosion and scaling potential in rural water distribution network of Urmia, Iran. $\begin{array}{llllll}\text { Desalination and Water } & \text { Treatment, } & \text { p. } & 1-8, & \end{array}$ http://dx.doi.org/10.1080/19443994.2015.1042058

LIANG, J.; DENG, A.; XIE, R.; GOMEZ, M.; HU, J.; ZHANG, J. et al. Impact of flow rate on corrosion of cast iron and quality of re-mineralized seawater reverse osmosis (SWRO) membrane product water. Desalination, v. 322, p. 76-83, 2013. https://doi.org/10.1016/j.desal.2013.05.001 
LIU, H.; GU, T.; LV, Y.; ASIF, M.; XIONG, F.; ZHANG, G. et al. Corrosion inhibition and anti-bacterial efficacy of benzalkonium chloride in artificial $\mathrm{CO}_{2}$-saturated oilfield

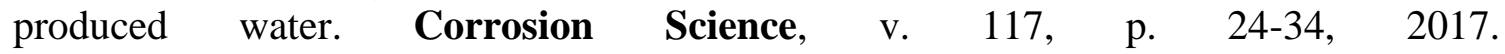
http://dx.doi.org/10.1016/j.corsci.2017.01.006

MIRZABEYGI, M.; ABBASNIA, A.; YOUZI, H.; ALIKHANI, M.; MAHVI, A. Evaluation of groundwater quality and assessment of scaling potential and corrosiveness of water supply networks, Iran. Research and Technology-AQUA, p. 1-10, 2017. https://doi.org10.2166/aqua.2017.128

OMAKA, O. N.; OFFOR, I. F.; ONWE, I. M. Hydrogeochemical attributes and ground water quality of Ngbo Community in Ohaukwu Area Council, Ebonyi State, Nigeria. Revista Ambiente \& Água, v. 10, n. 1, p. 35-47, 2015. http://dx.doi.org/10.4136/ambi-agua.1453

PENG, C.; FERGUSON, J.; KORSHIN, G. Effects of chloride, sulfate and natural organic matter (NOM) on the accumulation and release of trace-level inorganic contaminants from corroding iron. Water Research, v. 47, n. 14, p. 5257-5269, 2013. https://doi.org/10.1016/j.watres.2013.06.004

SORLINI, S.; BIASIBETTI, M.; ABBÀ, A.; COLLIVIGNARELli, M. C.; DAMIANI, S. Water Safety Plan for drinking water risk management: the case study of Mortara (Pavia, Italy). Revista Ambiente \& Água, v. 12, n. 4, p. 513-526, 2017. http://dx.doi.org/10.4136/ambi-agua.2102

TAVANPOUR, N.; NOSHADI, M.; TAVANPOUR, N. Scale Formation and Corrosion of Drinking Water Pipes: A Case Study of Drinking Water Distribution System of Shiraz City. Modern Applied Science, v. 10, n. 3, p. 166-177. 2016. http://dx.doi.org/10.5539/mas.v10n3p166

VAZDIRVANIDIS, A.; PANTAZOPOULOS, G.; RIKOS, A. Corrosion investigation of stainless steel water pump components. Engineering Failure Analysis, v. 82, p. 466-473, 2016. https://doi.org/10.1016/j.engfailanal.2016.09.009

WANG, Y.; CHENG, G.; WU, W.; QIAO, Q.; LI, Y.; LI, X. Effect of pH and chloride on the micro-mechanism of pitting corrosion for high strength pipeline steel in aerated $\mathrm{NaCl}$ solutions. Applied Surface Science, v. 349, p. 746-756, 2015. https://doi.org/10.1016/j.apsusc.2015.05.053

YANG, F.; SHI, B.; GU, J.; WANG, D.; YANG, M. Morphological and physicochemical characteristics of iron corrosion scales formed under different water source histories in a drinking water distribution system. Water Research, v. 46, n. 16, p. 5423-5433, 2012. https://doi.org/10.1016/j.watres.2012.07.031

YOUSEFI, M.; SALEH, H. N.; MAHVI, A. H.; ALIMOHAMMADI, M.; NABIZADEH, R.; MOHAMMADI,A. A. Data on corrosion and scaling potential of drinking water resources using stability indices in Jolfa, East Azerbaijan, Iran. Data Brief, v. 16, p. 724-731, 2018. https://doi.org/10.1016/j.dib.2017.11.099

ZHANG, X.; MI, Z.; WANG, Y.; LIU, S.; NIU, Z.; LU, P. et al. A red water occurrence in drinking water distribution systems caused by changes in water source in Beijing, China: mechanism analysis and control measures. Frontiers of Environmental Science \& Engineering, v. 8, n. 3, p. 417-426, 2014. https://doi.org/10.1007/s11783-013-0558-4 


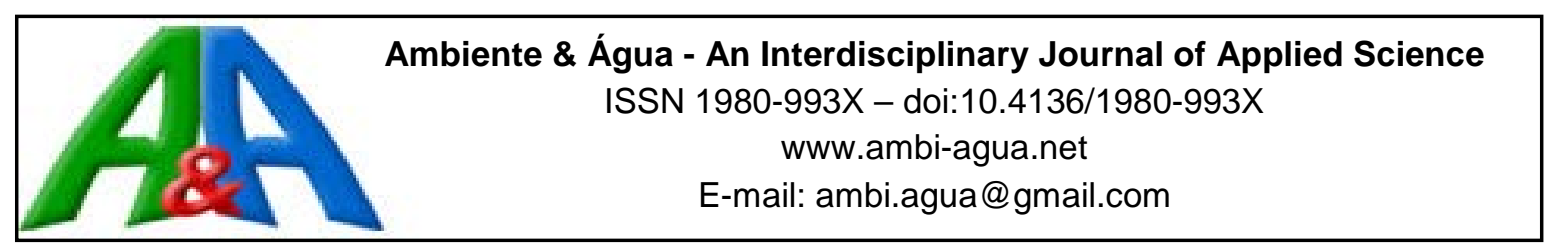

\title{
Daily water demand
}

\section{ARTICLES doi:10.4136/ambi-agua.2239}

Received: 08 Feb. 2018; Accepted: 31 Jul. 2018

\author{
Francesco Lombardi ${ }^{1}$; Guglielmo Silvagnii ${ }^{1}$; Piero Sirini²; \\ Riccardo Spagnuolo ${ }^{1}$; Fabio Volpi ${ }^{1^{*}}$ \\ ${ }^{1}$ University of Rome "Tor Vergata", Rome, Italy \\ Department of Civil Engineering and Computer Science Engineering. \\ E-mail: lombardi@ing.uniroma2.it, silvagni@ing.uniroma2.it, \\ r.spagnuolo@ing.uniroma2.it, volpi@ing.uniroma2.it \\ ${ }^{2}$ University of Florence, Florence, Italy \\ Department of Civil and Environmental Engineering. \\ E-mail: pierosirini15@gmail.com \\ *Corresponding author
}

\begin{abstract}
This paper develops a model to characterize the demand for domestic water based on its end users' usage habits. The use of individual residential appliances (bathroom sink, toilet, shower, bath, etc.) is interpreted using a probabilistic approach. The paper also applies the model to the distribution network of the municipality of Sparanise, a small city in the province of Caserta, Italy. The results of this application are compared to the real output of the city's actual water reservoir. Flow variability during the day was successfully modelled. A comparison of the simulated and recorded data on a daily level indicates the proper adjustment of the volume distribution; the peak flow rates were also comparable. The model could be a useful tool for analyzing domestic water consumption, especially in the design and management of water distribution networks. Use of the model would particularly aid the Integrated Urban Water Management Operator both in optimizing the operating pressures in the various districts' networks and in predicting domestic water consumption when drafting its water balance documents.
\end{abstract}

Keywords: domestic appliances, management, probabilistic model, water demand, water distribution network.

\section{Demanda hídrica diária}

\section{RESUMO}

No artigo é proposto um modelo para caracterizar a demanda hídrica doméstica a partir dos hábitos de utilização dos usuários finais de água. O uso dos equipamentos domésticos (bidê, pia, chuveiro, banheira, lava-roupas, etc.) é analisado com o uso de abordagem probabilística. Também é descrita a aplicação do modelo na rede de distribuição do município de Sparanise na Província de Caserta (Itália) e a consequente verificação dos resultados obtidos com aqueles registrados diretamente na saída para o reservatório da cidade. A comparação entre os dados registrados mostrou um bom ajuste do volume distribuído diariamente, os volumes de pico também se mostraram compatíveis. O modelo se mostrou como instrumento útil para análise do consumo doméstico com grande potencial de aplicação no projeto e na gestão das redes de 
distribuição. Em particular a utilização do modelo poderia auxiliar o Órgão de Gestão Integrada de Recursos Hídricos na otimização das pressões operacionais nas redes subdivididas em distritos e para prever o consumo de água doméstico quando da elaboração de relatórios de balanço hídrico.

Palavras-chave: demanda hídrica, equipamentos domésticos, gestão, modelo probabilístico, rede de distribuição hídrica.

\section{INTRODUCTION}

Integrated Urban Water Management (IUWM) consists of all public services relating to water management, such as catchment, conveyance and distribution of water for civil uses, and sewage and wastewater treatment.

Current Italian regulations require that IUWM is managed with respect to the principles of efficiency, effectiveness and affordability. The achievement of the above principles must necessarily also comprise knowledge of the complex infrastructure system, its current performance levels, the volumes collected and distributed, and the flows collected in the final receptors of the sewer system.

In an urban center, the variability of the water demand over time describes its functional range and is also a useful tool for its managing institutions in order to correctly manage the service.

Civil consumption of water depends on a variety of uses which can be related to multiple components. Civil consumption is generally separated into two components: domestic consumption and collective consumption.

Domestic consumption is intended as the water demand of dwelling occupants; collective consumption is instead usually considered consumption by public and commercial activities.

Public consumption takes into account all civil consumption, which is not generated by the residential users. When industrial consumption is restrained, it is counted as collective consumption.

Experimental investigations carried out in ten municipalities located in Southern Italy showed a baseline consumption value which remained more or less constant throughout the day (Silvagni et al., 2004).

This value also considers the presence of losses - a physiological component which is always present in distribution networks - and the collective consumption component (Figure 1 and 2).
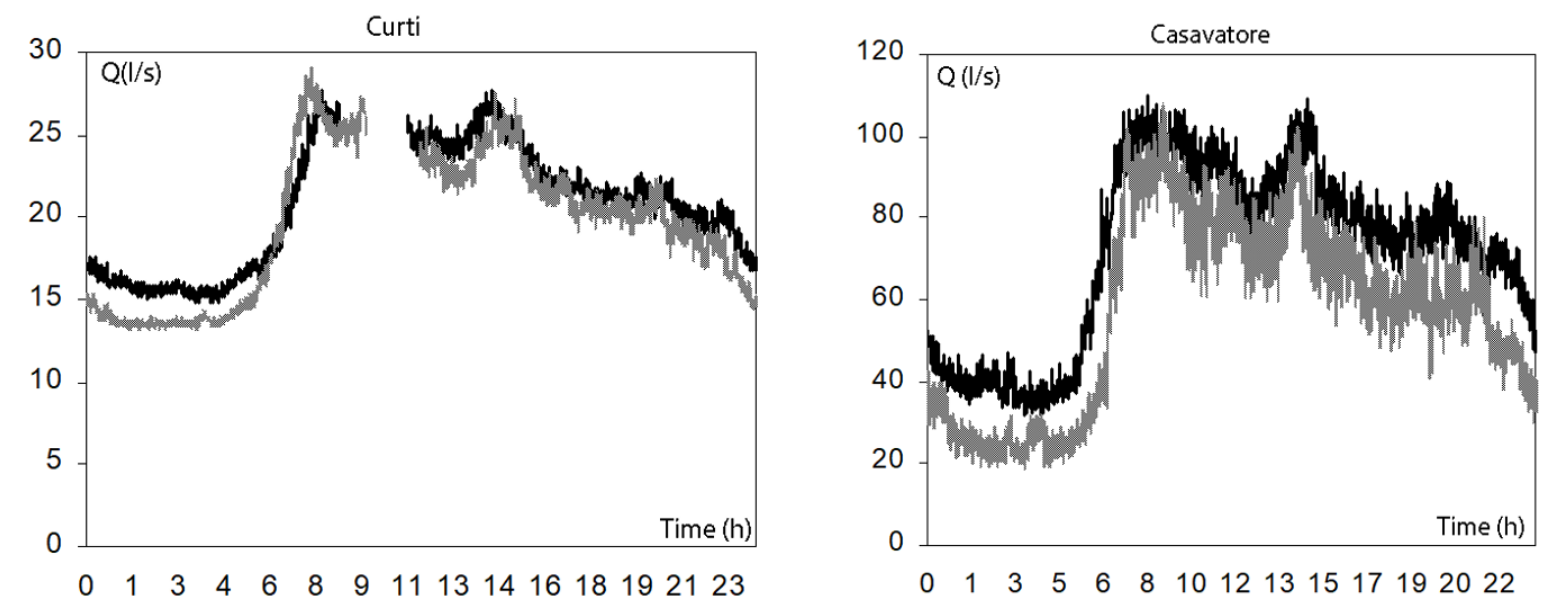

Figure 1. Plots of city reservoir output flows. 


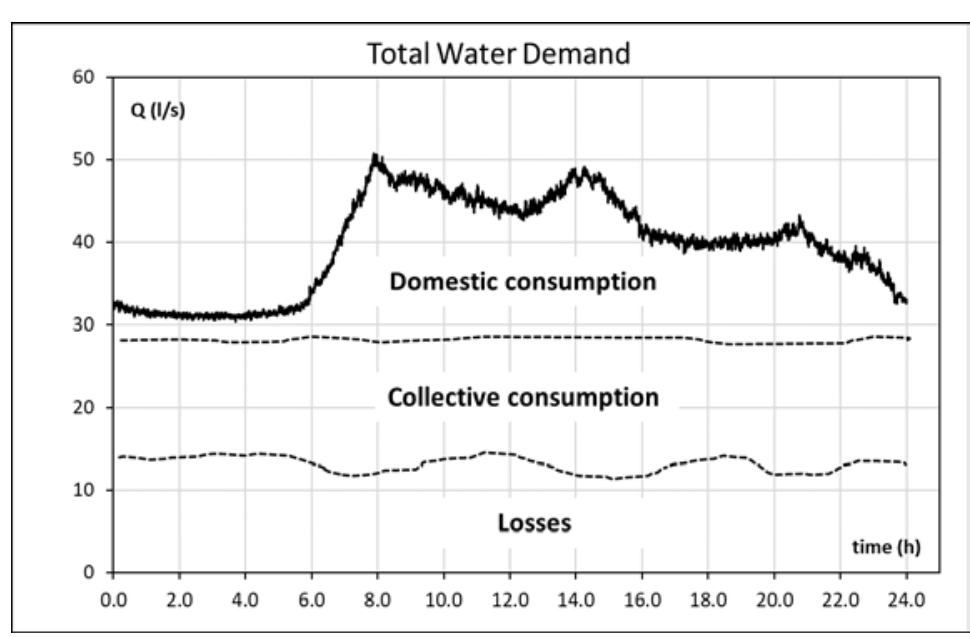

Figure 2. Plot indicating the division of consumption based on flow - time.

Therefore, the output flow $\mathrm{Q}_{\mathrm{L}}[\mathrm{l} / \mathrm{s}]$ in Figure 1 can be expressed as the sum of domestic flow $Q_{D}[\mathrm{l} / \mathrm{s}]$, collective flow $Q_{C}[\mathrm{l} / \mathrm{s}]$ and losses $Q_{P}[\mathrm{l} / \mathrm{s}]$ (Equation 1 ).

$Q_{L}=Q_{D}+Q_{C}+Q_{P}[\mathrm{l} / \mathrm{s}]$

The estimation of network losses is basic to correct IUWM operator management, as it is a fundamental aspect of the water balance; indeed, the detection, estimation and resolution of the losses allow the managing institutions to optimize service with direct, positive repercussions on administrative aspects.

Estimating losses is a complex task based on the comparative analysis of the daily volumes delivered by the distribution network, the volumes invoiced to users and the volumes delivered to collective users. In technical literature, some models have been proposed for estimating the vulnerability and incidence of the losses (Infrastructure Leakage Index - ILI), which are based on a network's topography, type and working pressures (Lambert et al., 1999; Lambert, 2000; Thornton and Lambert, 2006).

Collective consumption depends on the type of town planning and the socio-economic services present in the area; they are generally identified with special water supply contracts. Detailed knowledge of the system and its users allows for the direct estimation of the amounts of water delivered in the provision of services to citizens and production systems.

Domestic consumption is directly correlated to the number of inhabitants and their daily habits; it varies from urban center to urban center within the geographic areas considered (Silvagni et al., 2004), and within the various water districts relating to town planning types.

The model described in this paper makes it possible to estimate domestic demand based on domestic appliances and users' daily habits.

The characterization of users' water demand together with the estimates of collective volumes and respective losses therefore makes it possible to create a diagram indicating the daily water demand required by each urban center analyzed.

The model can be applied to the entire urban center, as well as to the different, homogeneous water districts within the same center. The result is a snapshot of water use over space and time, with obvious benefits for monitoring and managing the water supply system.

The technical literature on the analysis of users' water demand has essentially targeted the estimation of per capita daily water volume. These studies often reveal a weakness in the system: they highlight that the daily drinking water demand is higher than the available amount of natural water, also as a consequence of climate changes (Fox et al., 2009; Schleich and Hillenbrand, 2009; Arbués et al., 2003; Levallois et al., 1998). 
Other studies have focused more on characterizing the demand within a broader context of reducing losses to reduce use of the available amount of water (e.g. Makropoulos and Butler, 2007; Bertola et al., 2014; Parker and Wilby, 2013).

A recent study (Gargano et al., 2016) presented a probabilistic model that allows for users' demand to be estimated based on residential meter readings.

The proposed methodology for defining domestic water demand is based on the experiences carried out in the sewage networks and in particular on the analysis of domestic users' waste (Butler, 1991; 1993; Butler and Graham, 1995). The aim of this study is to link demand to the number and type of appliances existing inside a home and their use during a typical day.

Therefore, the estimation of each appliance's usage times and frequency is necessary, as well as the volume and variability of the water used.

Butler and Graham (1995) developed a probabilistic model for a sewage network to simulate the spatial and temporal variation of domestic wastewater in dry weather conditions.

The discharged wastewater was considered equivalent to the volume of water delivered to users.

Water demand is the result of the random use of domestic appliances, each one with its own characteristics (i.e. usage volume and variability, assumed as randomly variable within certain ranges) and with usage frequency related to defined hourly periods of the day. These flows have an intermittent nature and are used for limited durations (in the range of 10-15 s).

The probability $p$ that an appliance will be used in time interval $T_{a}$ is given by Equation 2:

$p=\frac{t_{a 1}}{T_{a}}<1$

where $t_{a 1}$ is the total observed time during which the hydro-sanitary device delivers water.

The probability of having $r$ appliances out of a total $N$ appliances which are simultaneously in use can be determined with a binomial distribution expressed by the following relationship Equation 3:

$p(r)=\frac{N !}{r !(N-r) !} p^{r}(1-p)^{N-r}$

The binomial distribution makes it possible to determine the expected amount of simultaneous uses $E(r)$ in a generic moment in time as the product of $\mathrm{N}$ appliances and probability $p(r)$.

The resulting flow $E_{q}(r)$ relating to the simultaneous use of multiple appliances is determined (Butler and Graham, 1995) by the product of the expected number of simultaneous uses $E(r)$ and the initial flow q of the single appliance considered (Equation 4).

$E_{q}(r)=E(r) \cdot q$

Butler and Graham (1995) also indicate the possibility of extending their theory to define a mean or expected flow value generated by intermittent demand to estimate the flow variability around its mean value.

This transposition is possible through the use of the standard deviation $\sigma$ (Equation 5) of the simultaneous demand expressed by means of normal distribution (Shaw, 1963), and the calculated flow variability.

$\sigma=\sqrt{N p(1-p)}$ 
The amount of simultaneous demand $E^{\alpha}(r)$ and the resulting flow $E q^{\alpha}(r)$ are related to a fixed level of confidence $\alpha$ (confidence coefficient $Z^{\alpha}$ ) (Equation 6).

$E^{\propto}(r)=N p \pm Z^{\propto} \sigma \rightarrow E_{q}^{\propto}(r) \cdot q$

Butler and Graham (1995) applied this probabilistic model to the English sewer system of Edenbridge, obtaining an excellent correspondence between recorded and simulated flood hydrographs.

The approach used, which starts with a typical distribution of equipment and home appliances, allows for both a characterization of domestic demand in existing networks and the estimate of demand charts for project design. In fact, domestic water demand can be estimated starting with the data available from regulations based on town planning type, the number and type of apartments and the maximum number of occupants.

An important aspect highlighted by Butler $(1991 ; 1993)$ is the variability of the parameters depending on geographical areas (northern or southern Europe) or lifestyle (lower class, upper class); previous studies have already highlighted this variability in some distribution networks in Southern Italy (Silvagni et al., 2004). The domestic demand charts for certain towns in the Campania Region have shown trends and parameters of the harmonic functions which depict them as being comparable with one another (Figure 3).
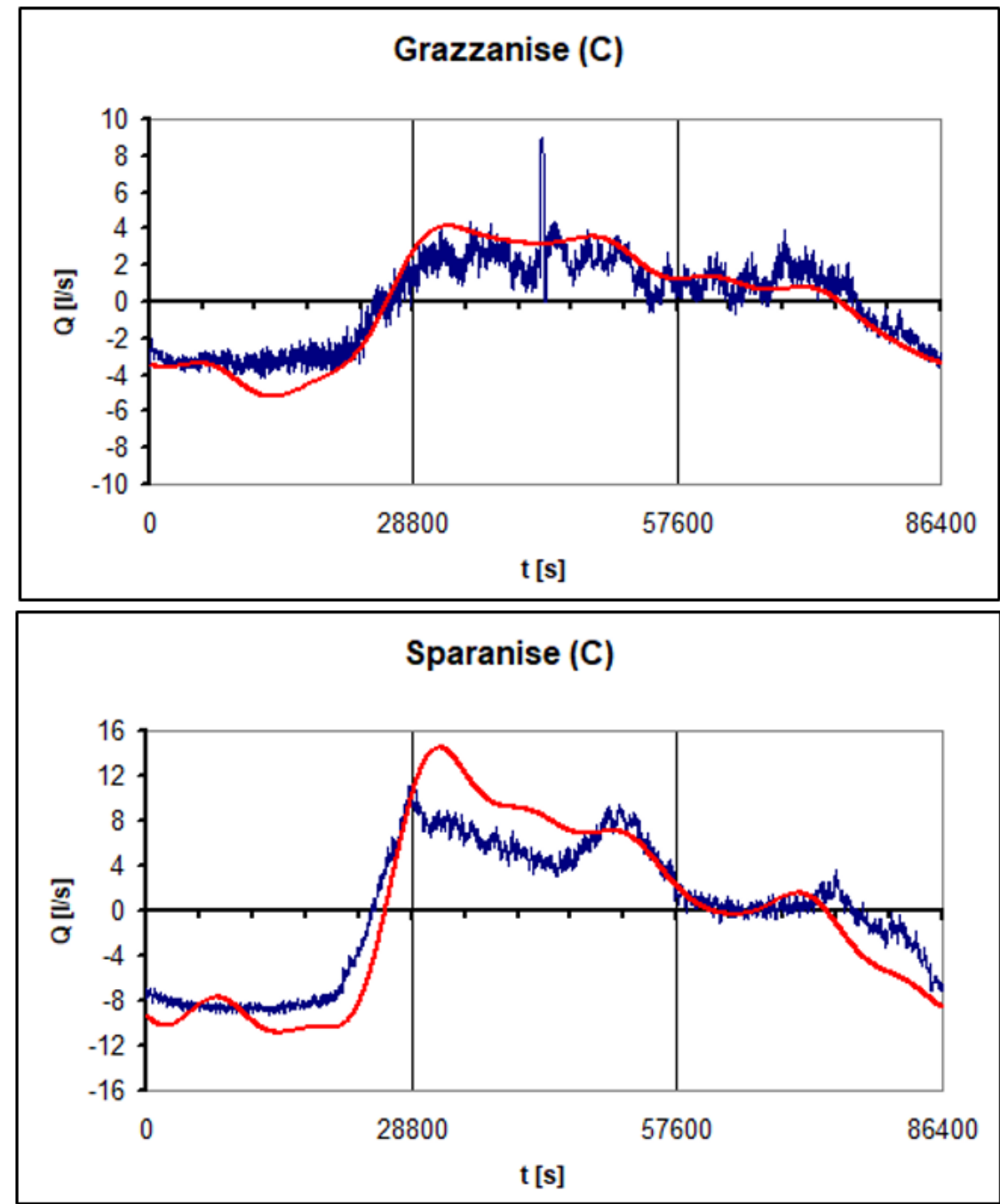

Figure 3. Charts recorded vs. reconstructed sinusoidal signals (Silvagni et al., 2004). 


\section{MATERIALS AND METHODS}

In this first stage, the proposed model considers middle-class users without any specifications regarding age, profession or economic-cultural conditions.

The daily use of appliances by a typical user was set in reference to a standard domestic environment.

The individual appliances were characterized using four parameters:

1. Average daily frequency of use [uses/day];

2. Start time of use during the day [h];

3. Average duration of appliance use [minutes/use];

4. Volume of water required [litres/use].

For domestic appliances, a probabilistic process must be applied by estimating the standard deviation $(\sigma)$ compared to the mean value.

In particular, and in agreement with Butler and Graham (1995), a normal distribution around the mean value $\mu$ was assumed.

This assumption makes it possible to consider the habits, lifestyles and different needs of users, which can cause significant variability in the manner and frequency of use.

The daily demand hydrograph of users is strongly influenced by $\sigma$; an experimental investigation with flow-demand measurements and users' daily usage reports is the most effective tool for correctly estimating the standard deviations.

In this first development phase of the probabilistic model, the $\sigma$ values for the various types of appliances tested were assumed equal to Butler's experimentally estimated values (1991, 1993), suitably adjusted according to the estimated habits and lifestyles of the population which was subsequently studied in this paper.

The probability density function of the normal distribution $p d f$ is expressed by the following (Equation 7), as a function of the average value $\mu$ and the standard deviation $\sigma$ :

$f(t, \mu, \sigma)=\frac{1}{\sqrt{2 \pi} \sigma \sigma} e^{-\frac{(t-\mu)^{2}}{2 \sigma^{2}}}$

With a daily number of users greater than one, the effects due to the single $p d f(t)$ must be combined.

Figure 4 shows the Probability Density Functions $(P d f)$ for the start time of using the sink.

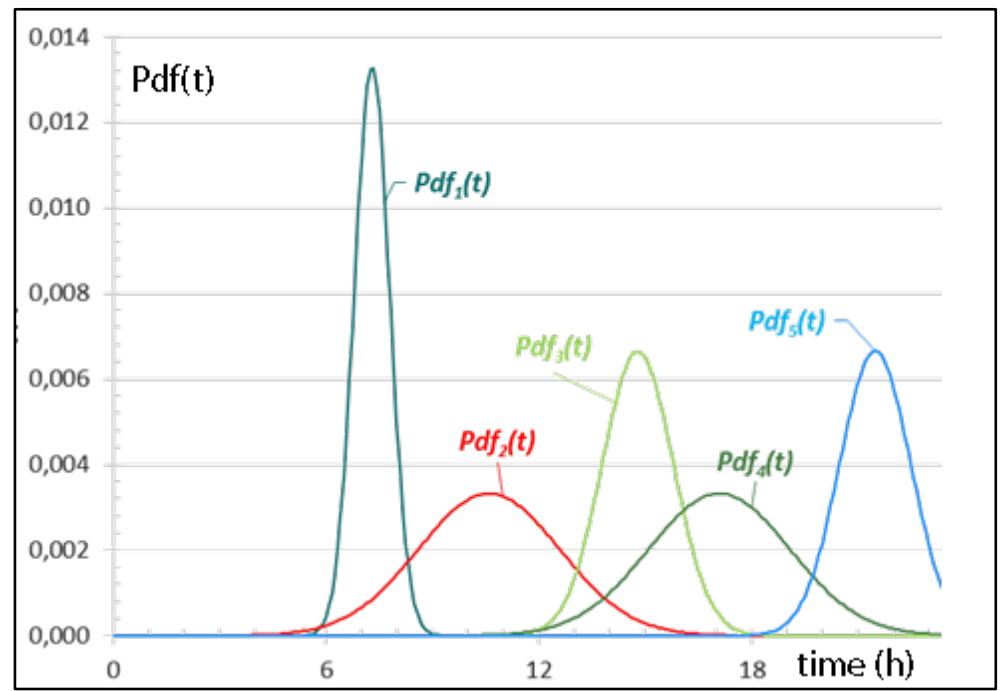

Figure 4. Use start time - Pdf. 
A random process makes it possible to estimate the start time, duration and volume of use throughout the day for the appliance in question. Figure 5 shows the daily chart for a sink.

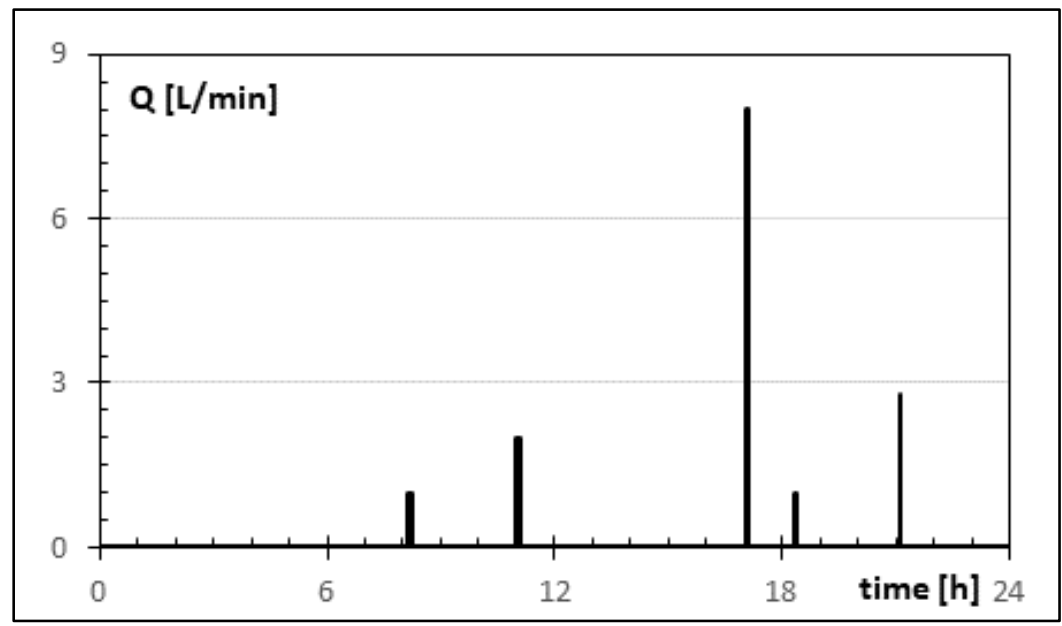

Figure 5. Sink - Estimated daily demand.

The chart in Figure 6 shows the water demand considering a number of users $(N)$ equal to 20 and considering other domestic appliances (kitchen sink, shower, bathtub, toilet, washing machine, dishwasher, etc.) in addition to the bathroom sink.

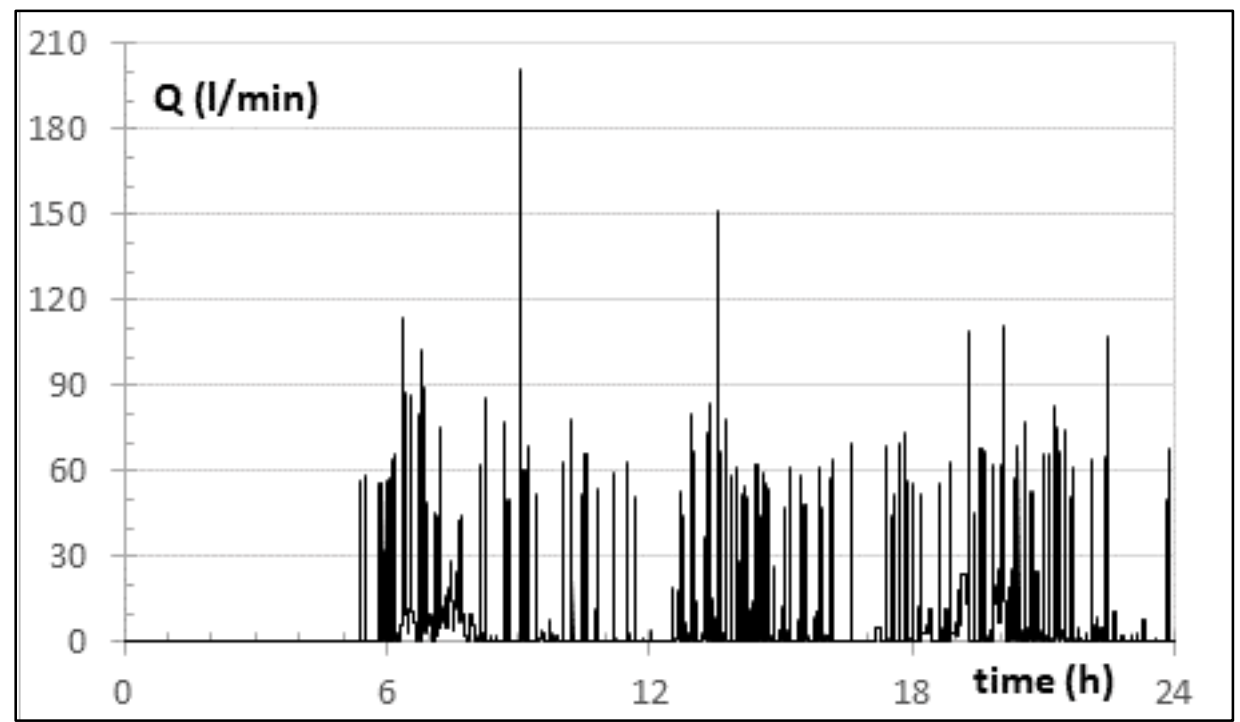

Figure 6. Typical user - Estimated daily demand $-N=20$

This model was applied and adjusted to the municipality of Sparanise in the province of Caserta (Italy).

\section{RESULTS AND DISCUSSION}

The monitoring system of Sparanise water distribution network provided daily demand data for a study characterizing water consumption (Silvagni et al., 2002).

The municipality of Sparanise has about 7,000 inhabitants and is predominantly residential.

The diagrams in Figure 7 show the recorded city reservoir output data, both as recorded (a) and as filtered data (b), linked to traditional uses (collective) and the net losses deducted from the overnight time range $(\mathrm{t}=0 \div 6 \mathrm{~h}$, Figure $7 \mathrm{a})$.

\section{IPABH}

Rev. Ambient. Água vol. 13 n. 5, e2239 - Taubaté 2018 

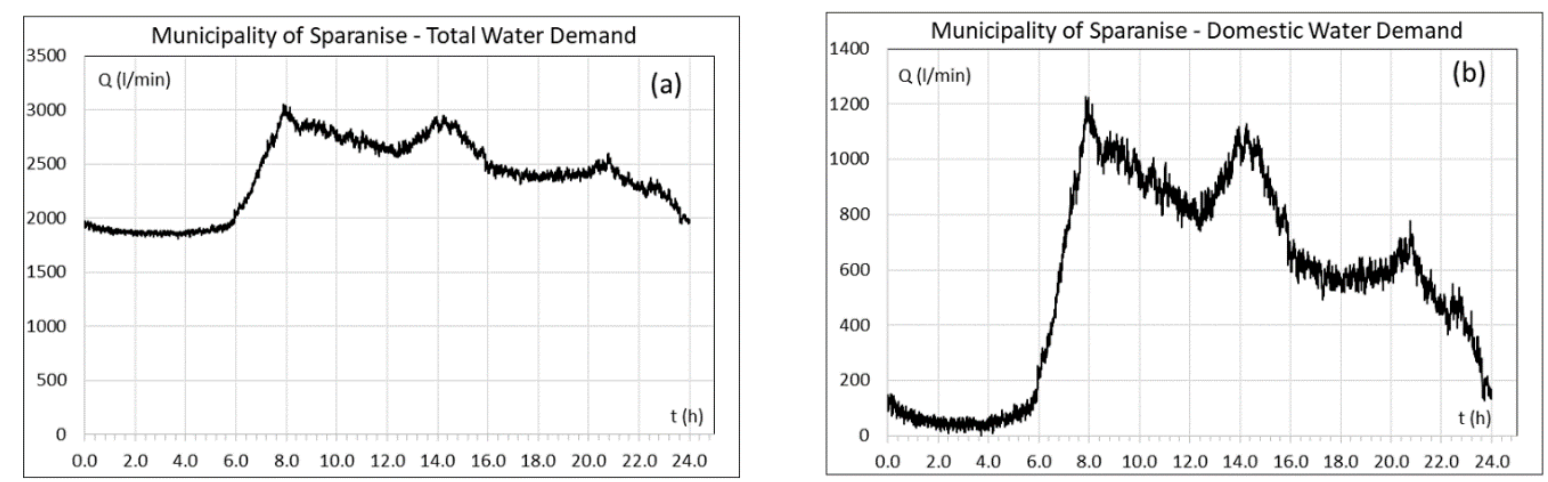

Figure 7. Municipality of Sparanise - Water Demand (April 1995).

Table 1 shows the model parameter values, mean value $(\mu)$ and standard deviation $(\sigma)$, estimated for Sparanise using data from the literature (Butler 1991; 1993; Blokker et al., 2006; 2010; Buchberger and $\mathrm{Wu}, 1995)$, which is based on the town planning type, average living standards and mostly residential water use.

The average use duration and mean volume are fixed and use the experimental results Butler obtained for wastewater (Butler, 1991), considering the flows that the appliances are able to distribute, also in reference to the existing technical standards (UNI, 2014).

A middle-class household was considered for the type of appliances examined: a household composed of three people with a single bathroom with a shower and bathtub, a kitchen with a dishwasher and a washing machine.

The shower and bathtub are considered as not generally being used simultaneously. The model assumes an average bathtub use of once per week. Therefore, considering that the user area consists of $\mathrm{N}$ typical users, the use of the bathtub on the reference date is by N/7 users; the remaining $6 \mathrm{~N} / 7$ users use the shower.

A similar consideration was made for the washing machine and dishwasher.

The hypothesis also includes the consideration that a single appliance is shared by three users. This hypothesis can be explained by considering the daily use of a family comprised of three people on average, or the appliance's use every three days on average by each individual user in question.

The average use frequency and times were set based on user behavior and by analyzing the consumption shown in Figure 7, which indicates three flow peaks at 8:00, 14:00 and 21:00.

Figure 8 depicts the first results of the model's application to the municipality of Sparanise. The model produced an optimal estimation of the peak demand values and overall, the demand trends obtained in the chart are quite in line with the chart of recorded data.

The results obtained for the time period from 9:00 to 12:30 underestimate the recorded flow data; although less marked, a similar trend emerges in the time period from 15:30 to 19:30.

The highlighted time periods both include the opening of commercial activities with the addition, between 9:00 and 12:30, of activities in the citizen services and public facilities sectors.

The above-mentioned activities are not considered within the proposed probabilistic method, which is aimed at domestic users. Therefore, the underestimation is certainly influenced by the initial assumption of removing a constant amount from the recorded values due to non-domestic users.

The time period deviation of the volume distributed to users between the probabilistic model and the recorded data has no significant effect on the overall daily volumes delivered. In fact, the daily water allocation estimated by the model (equivalent to 136 litres per inhabitant) is almost identical to the per capita available water supply recorded (134.7 litres per inhabitant). 
Table 1. Probabilistic model input.

\begin{tabular}{|c|c|c|c|c|c|c|c|c|c|}
\hline Domestic & Appliances & $\begin{array}{c}\text { Bathroom } \\
\text { Sink }\end{array}$ & Toilet & Bidet & Shower & Bathtub & $\begin{array}{c}\text { Kitchen } \\
\text { sink }\end{array}$ & Dishwasher & $\begin{array}{l}\text { Washing } \\
\text { Machine }\end{array}$ \\
\hline \multirow{2}{*}{$\begin{array}{c}\text { Use } \\
\text { duration }\end{array}$} & $\underset{\text { [min/use] }}{\mu_{\mathrm{d}}}$ & 1.0 & 1.5 & 0.6 & 4.0 & 6.0 & 1.0 & 0.7 & 5.0 \\
\hline & $\begin{array}{c}\sigma_{\mathrm{d}} \\
{[\mathrm{min} / \mathrm{use}]}\end{array}$ & 1.5 & 1.0 & 1.0 & 1.0 & 0.5 & 1.5 & 0.3 & 0.5 \\
\hline \multirow{2}{*}{ Volume } & $\mu_{v}[1 /$ use $]$ & 3.0 & 7.0 & 3.5 & 25.0 & 35.0 & 4.5 & 4.0 & 30.0 \\
\hline & $\sigma_{\mathrm{v}}[\mathrm{l} / \mathrm{use}]$ & 1.7 & 1.0 & 1.7 & 20.0 & 20.0 & 2.0 & 1.3 & 10.0 \\
\hline $\begin{array}{c}\text { Use } \\
\text { frequency }\end{array}$ & $\begin{array}{c}\mathrm{f} \\
\text { [use/day] }\end{array}$ & 4.0 & 4.0 & 2.0 & 2.0 & 1.0 & 3.0 & 3.0 & 2.0 \\
\hline \multirow{8}{*}{$\begin{array}{c}\text { Start time } \\
\text { use }\end{array}$} & $\mu_{1}[\mathrm{~h}]$ & 8.0 & 7.3 & 7.5 & 8.0 & 14.0 & 9.0 & 21.3 & 14.0 \\
\hline & $\sigma_{1}[\mathrm{~h}]$ & 1.5 & 1.5 & 1.5 & 1.5 & 1.0 & 1.5 & 8.0 & 12.0 \\
\hline & $\mu_{2}[\mathrm{~h}]$ & 13.5 & 17.0 & 21.0 & 14.0 & -- & 14.0 & 22.0 & 14.5 \\
\hline & $\sigma_{2}[\mathrm{~h}]$ & 1.0 & 2.0 & 1.5 & 1.5 & -- & 1.5 & 8.0 & 12.0 \\
\hline & $\mu_{3}[\mathrm{~h}]$ & 17.1 & 20.5 & -- & -- & -- & 21.0 & 22.2 & -- \\
\hline & $\sigma_{3}[\mathrm{~h}]$ & 2.0 & 1.0 & -- & -- & -- & 1.5 & 8.0 & -- \\
\hline & $\mu_{4}[\mathrm{~h}]$ & 21.5 & 23.0 & -- & -- & -- & -- & -- & -- \\
\hline & $\sigma_{4}[\mathrm{~h}]$ & 1.0 & 2.0 & -- & -- & -- & -- & -- & -- \\
\hline
\end{tabular}

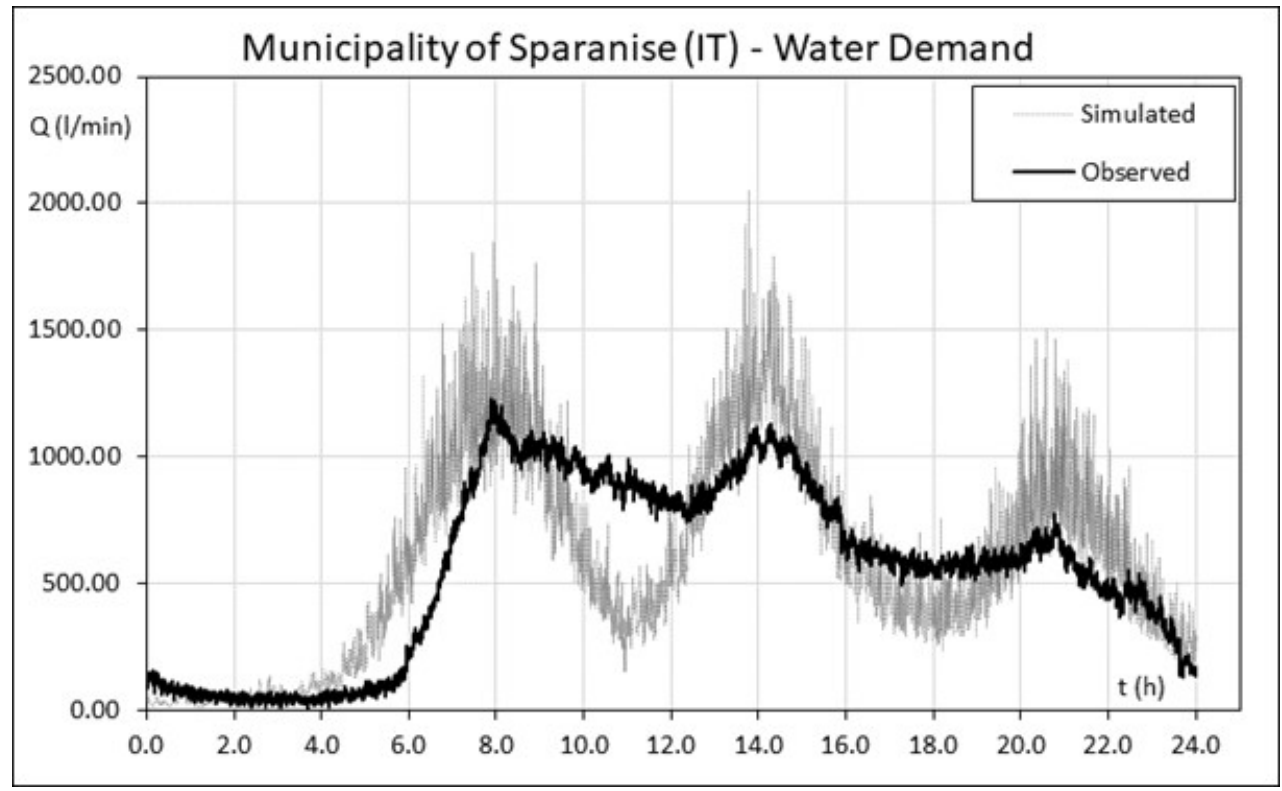

Figure 8. Model application - Results.

\section{CONCLUSIONS}

The variability of an urban center's water demand over time is directly related to its citizens' use of residential equipment. The probabilistic model proposed makes it possible to estimate users' hourly consumption, starting from the single residential unit.

In this first phase, the model was tested on Sparanise users which are predominantly residential, with commercial activities and public services for the community.

The results demonstrate that the proposed model can be effective for managing distribution networks, as it is able to temporally place and estimate peak flow values.

This aspect, especially in networks which are subdivided into districts, allows for the management of pressures in order to optimize the networks' operation and ensure the expected service level to users.

\section{IPABH}


The results obtained in the estimation of the user volume demand for domestic use show how the model can be used to define an urban centre's water balance, especially considering how this water balance consists of domestic consumption, collective consumption and losses. Further investigations and applications of the model are underway in order to confirm and thereby also generalize both the method and the results obtained from it.

\section{REFERENCES}

ARBUÉS, F.; GARZIA-VALINAS, M. A.; MARTINEZ-ESPIÑEIRA, R. Estimation of residential water demand: a state-of-the-art review. Journal of Socio-Economics, v. 32, p. 81-102, 2003. https://doi.org/10.1016/S1053-5357(03)00005-2

BERTOLA, P.; SILVAGNI, G.; NICOLINI, M.; VOLPI, F. A criterion for optimal management of water distribution networks. In: BREBBIA, C. A.; MAMBRETTI, S.

Urban Water II. Southampton: Wit Press, 2014. p. 39-50 http://dx.doi.org/10.2495\%2FUW140041

BLOKKER, E. J. M.; VREEBURG, J. H. G.; VOGELAAR, A. J. Combining the probabilistic demand model SIMDEUM with a network model./ In: ANNUAL INTERNATIONAL SYMPOSIUM ON WATER DISTRIBUTION SYSTEMS ANALYSIS, 8., Cincinnati, Ohio. Abstracts.... Reston: American Society of Civil Engineers, 2006. 1 CD-Rom.

BLOKKER, E. J. M.; VREEBURG, J. H. G.; VAN DIJK, J. C. Simulating residential water demand with a stochastic end-use model. Journal of Water Resources Planning and Management, v. 136, n. 1, p. 19-26, 2010. https://doi.org/10.1061/(ASCE)WR.19435452.0000002

BUCHBERGER, S. G.; WU, L. A model for instantaneous residential water demands. Journal of Hydraulic Engneering, v. 121, n. (3), p. 232-246, 1995. https://doi.org/10.1061/(ASCE)0733-9429(1995)121:3(232)

BUTLER, D. A small-scale study of wastewater discharges from domestic appliances. Journal of the Institution of Water \& Environmental Management, v. 5, p. 178-185, 1991. https://doi.org/10.1111/j.1747-6593.1991.tb00605.x

BUTLER, D. The influence of Dwelling occupancy and Day of the Week on Domestic Appliance Wastewater Discharges. Building and Environment, v. 28, p. 73-79, 1993. https://doi.org/10.1016/0360-1323(93)90008-Q

BUTLER, D.; GRAHAM, N. J. D. Modelling Dry Weather Wastewater Flow in Sewer Networks. Journal of Environmental Engineering, v. 121, p. 161-173, 1995. https://doi.org/10.1061/(ASCE)0733-9372(1995)121:2(161)

ENTE ITALIANO DI NORMAZIONE - UNI. UNI 9182:2014: Hot and cold water supply and distribution installations Design, testing and management criteria. Milano, 2014.

FOX, C.; MCINTOSH, B.S.; JEFFREY, P. Classifying households for water demand forecasting using physical property characteristics. Land Use Policy, v. 26, p. 558-568, 2009. https://doi.org/10.1016/j.landusepol.2008.08.004

GARGANO, R., TRICARICO, C., DEL GIUDICE, G., GRANATA, F. A Stochastic Model for Daily Residential Water Demand. Water Science \& Technology: Water Supply, v. 16, n. 6, p.1753-1767, 2016. https://doi.org/10.2166/ws.2016.102 
LAMBERT, A.; BROWN, T. G.; TAKIZAWA, M.; WEIMER, D. A Review of Performance Indicators for Real Losses from Water Supply Systems. AQUA, Journal of Water Services Research and Technology, v. 48, p. 227-237, 1999. https://doi.org/10.2166/aqua.1999.0025

LAMBERT, A. What do we know about pressure leakage: relationships in distribution systems? In: IWA CONFERENCE, 2000, Brno, Czech Republic. Proceedings on System Approach to Leakage Control and Water Distribution Systems management. Brno, 2000. 1 CD-ROM.

LEVALLOIS, P.; GUEVIN, N.; GINGRAS, S.; LEVESQUE, B.; WEBER, J. P.; LETARTE, R. New patterns of drinking-water consumption: results of a pilot study. The Science of the Total Environment, v. 209, p. 233-241, 1998. https://doi.org/10.1016/S00489697(98)80114-9

MAKROPOULOS, C.; BUTLER, D. Planning site-specific water-demand management strategies. Water and Environment Journal, v. 18, p. 29-35, 2007. https://doi.org/10.1111/j.1747-6593.2004.tb00489.x

PARKER, J. M.; WILBY, R. L. Quantifying Household Water Demand: A Review of Theory and Practice in the UK. Water Resources Management, v. 27, p. 981-1011, 2013. https://doi.org/10.1007/s11269-012-0190-2

SCHLEICH, J.; HILLENBRAND, T. Determinants of residential water demand in Germany. $\begin{array}{llllll}\text { Science } & \text { Direct, } & \text { v. } & 6809 .\end{array}$ https://doi.org/10.1016/j.ecolecon.2008.11.012

SHAW, V. A. The development of contributor hydrographs for sanitary sewers and their use in sewer design. Civil Engineering, v. 5, p. 246-252, 1963.

SILVAGNI, G.; SILEO, C.; FONTANA, M. Analisi dei consumi idropotabili e dei coefficienti di punta in alcuni Comuni dell'Italia Meridionale. In: DRUSIANI, R. L'evoluzione dei servizi idrici in Italia. Napoli: CUEN, 2002.

SILVAGNI, G.; FORTUCCI, C.; VOLPI, F. La domanda idropotabile giornaliera. In: BERTOLA, P.; FRANCHINI, M. La Gestione e l'affidabilità dei Sistemi Acquedottistici. Castrolibero: Bios sas, 2004. p. 75-86.

THORNTON, J.; LAMBERT, A. Managing pressures to reduce new breaks. Water 21 - Water Quality International, p. 24-26, 2006. 


\begin{tabular}{|} 
Ambiente \& Água - An Interdisciplinary Journal of Applied Science \\
ISSN 1980-993X - doi:10.4136/1980-993X \\
www.ambi-agua.net \\
E-mail: ambi.agua@gmail.com
\end{tabular}

\title{
Future scenarios of thermal bioclimatic conditions in a humid tropical city under urban development
}

\author{
ARTICLES doi:10.4136/ambi-agua.2092
}

Received: 07 Feb. 2017; Accepted: 08 Jul. 2018

\author{
Vicente de Paulo Rodrigues da Silva ${ }^{1 *}$; Joel Silva Santos ${ }^{2}$; \\ Eduardo Rodrigues Viana de Lima²; Romildo Morant de Holanda ${ }^{3}$; \\ Enio Pereira de Sousa'; Lincoln Eloi de Araújoº \\ ${ }^{1}$ Universidade Federal de Campina Grande (UFCG), Campina Grande, PB, Brasil \\ Departamento de Ciências Atmosféricas (DCA). E-mail: vicente.paulo@ufcg.edu.br, enio.souza@ufcg.edu.br \\ ${ }^{2}$ Universidade Federal da Paraíba (UFPB), João Pessoa, PB, Brasil \\ Departamento de Engenharia e Meio Ambiente (DEMA).E-mail: joelgrafia.santos@gmail.com, \\ eduvianalima@gmail.com, lincolneloi@yahoo.com.br \\ ${ }^{3}$ Universidade Federal Rural de Pernambuco (UFRPE), Recife, PB, Brasil \\ Departamento de Tecnologia Rural (DTR). E-mail: romildomorant@gmail.com \\ ${ }^{*}$ Corresponding author
}

\begin{abstract}
Urbanization modifies the heat balance in urban areas and has negative effects on landscape, aesthetics, energy efficiency, human health and the inhabitants' quality of life. This work evaluated future scenarios of bioclimatic conditions for João Pessoa, a humid tropical city in Northeast Brazil. The scenarios were determined based on trends in air temperature, relative humidity and wind speed for the time period from 1968 to 2015. The study was performed for two distinct periods of three months each (dry and wet seasons) using data from weather stations equipped with thermo-hygrometers and cup anemometers located in nine representative areas of the city. Trends in air temperature, relative humidity, wind speed, and effective temperature index (ET index) time series were evaluated using the Mann-Kendall test. Results indicated that the air temperature showed an increasing trend of $0.34^{\circ} \mathrm{C} /$ decade, whereas the relative humidity showed a decreasing trend of $0.49 \% /$ decade and the wind speed values ranged from $1.3 \mathrm{~ms}^{-1}$ to $3.80 \mathrm{~ms}^{-1}$. These trends are statistically significant according to the Mann-Kendall test $(\mathrm{p}<0.05)$. The air temperature increased between the 1980s and 2010s, which corresponds to a period of rapid urbanization of the city. Future environmental conditions in João Pessoa will be determined in accordance with the urbanization processes.
\end{abstract}

Keywords: Mann-Kendall test, thermal comfort, urban climate.

\section{Cenários futuros das condições bioclimáticas térmicas de uma cidade tropical úmida sob o aspecto de desenvolvimento urbano}

\section{RESUMO}

O processo de urbanização modifica o balanço térmico nas áreas urbanas e tem efeitos negativos na paisagem, na estética, na eficiência energética, na saúde humana e na qualidade de vida dos seus habitantes. O objetivo principal deste trabalho foi avaliar os cenários futuros das condições bioclimáticas de João Pessoa, uma cidade tropical úmida localizada no Nordeste 
do Brasil. Os cenários foram determinados com base nas tendências da temperatura do ar, velocidade do vento e da umidade relativa para o período de 1966 a 2015. Este estudo foi realizado durante dois períodos distintos de três meses cada (estação seca e estação úmida) usando dados da estação meteorológica equipada com um sistema termo-higrômetro e anemômetro de concha localizados em 9 áreas representativas da cidade. A tendência nas séries temporais de temperatura do ar, umidade relativa, velocidade do vento e do índice de temperatura efetiva (ET índice) foi avaliada usando o teste de Mann-Kendall. Os resultados indicaram que a temperatura do ar mostra uma tendência crescente de $0,34^{\circ} \mathrm{C} /$ década, enquanto a umidade relativa apresenta uma tendência decrescente de 0,49\% /década e os valores da velocidade do vento variam de $1,3 \mathrm{~ms}^{-1}$ a $3,80 \mathrm{~ms}^{-1}$. Essas tendências são estatisticamente significativas de acordo com o teste de Mann-Kendall ( $\mathrm{p}<0,05)$. A temperatura do ar aumentou entre os anos de 1980 e 2010, o que corresponde a um período de rápida urbanização da cidade. As futuras condições ambientais em João Pessoa serão determinadas de acordo com o processo de urbanização.

Palavras-chave: clima urbano, conforto térmico, teste de Mann-Kendall.

\section{INTRODUCTION}

Since microclimatic conditions have a major influence on people's comfort, the issue of outdoor thermal comfort has attracted wide attention in recent years. An estimated three billion people living in urban areas throughout the world are directly exposed to problems related to urban heat island intensity (UHI), which are expected to increase significantly in the near future (Tong et al., 2005; Memon et al., 2008). Several studies have addressed this theme in several different urban climates due to the worldwide severity of the problem, and a wide range of literature is available on the subject (Silva et al., 2010; Salvati et al., 2017; Lobaccaro et al., 2017; Rafael et al., 2017).

The temporal and spatial behavior of air temperature, relative humidity and wind speed are mainly affected by meso- and micro-scale differences in the natural and artificial morphology (Gulyás et al., 2006; Han et al., 2009; Matzarakis et al., 2010). These effects are significant for different levels of regional and urban planning, such as the design of urban parks, assessment of radiation conditions in urban canyons, and a variety of other applications. The growth of a metropolitan area and rise in air pollution levels lead to increases in urban air temperature, energy consumption and heat stress (Krüger et al., 2011; Veremchuk et al., 2016). One of the possible causes of these environmental problems is the drastic reduction of green spaces within cities. Therefore, as cities expand, land use planning becomes critical for determining environment quality because changes in land use from green areas to newly built structures result in changes in the natural surface of the earth (Jusuf et al., 2007; Wu et al., 2016). Meteorological variables, including solar radiation, air temperature, relative humidity, and wind speed have a significant bearing on human comfort and the perception of indoor and outdoor conditions. Specifically, the effect of air velocity on the thermal sensation depends on the environmental temperature. For example, at temperatures below $32^{\circ} \mathrm{C}$, increases in air velocity reduce the sensation of heat, whereas at temperatures between approximately $33^{\circ} \mathrm{C}$ and $37^{\circ} \mathrm{C}$, air velocities do not significantly affect the thermal sensation (Robaa, 2003; Yu et al., 2006). Impervious surfaces can contribute to the formation of UHI, which has significant adverse effects on the quality of the urban environment and the sustainable development of cities. Because vegetation can mitigate the effects of UHIs caused by artificial urban land uses, the UHI problem is more severe in cities with large populations and extensive economic activities (Tseliou et al., 2010). 
The basic hypothesis of this study is that changes in land from green areas to impervious surfaces in a city affect the absorption of solar energy, and changes in wind speed patterns due to buildings results in changes in air temperature and, consequently, changes in human discomfort perception. Since over $50 \%$ of the world's population live in urban areas, it is important to be able to project future bioclimatic conditions in outdoor spaces. Our study predicts future thermal comfort scenarios for the studied region based on changes in air temperature and relative humidity. This analysis is broadly divided into trend and regression analyses for obtaining the spatial configuration of thermal comfort during dry and rainy seasons. This work provides residents, city planners and governments with a methodology that supports the development of a more comfortable city area.

\section{MATERIALS AND METHODS}

\subsection{Study area}

The city of João Pessoa is located at latitude $-7^{\circ} 14^{\prime} 29^{\prime \prime}$ and longitude $-34^{\circ} 47^{\prime} 36^{\prime \prime}$ in the tropical humid climate of Brazil. The predominant vegetation type is Atlantic Forest fragments. The city is bounded by the Atlantic Ocean to the east and experiences the influence of several important large-scale precipitation mechanisms due to its location, such as the Atlantic intertropical convergence zone, upper air cyclonic vortex and cold fronts (Kolotroni and Giridharan, 2008). João Pessoa lies on a relatively flat coastal plain and has an average elevation of $33 \mathrm{~m}$. The annual average temperature ranges between $21^{\circ} \mathrm{C}$ and $31^{\circ} \mathrm{C}$, and the normal annual rainfall is approximately $1800 \mathrm{~mm}$ (Silva et al., 2006). The dry season generally occurs between January and June, and the rainy season occurs between July and December. The meteorological data for trend analysis in wind speed, air temperature and relative humidity were provided by the Brazilian National Institute of Meteorology (Inmet, in Portuguese). Before conducting the analysis, the quality and adequacy of data were assessed. The data at each measurement site were acquired at hourly intervals.

\subsection{Measurements}

Measurements of air temperature, relative humidity and wind speed were performed in nine zones that were chosen to represent the most densely populated areas and various types of land cover in the urban spaces and rural areas surrounding the city (Table 1). Mata do Buraquinho (P01) was adopted as the reference area in this study due to its high-density Atlantic forest vegetation. This vegetation type clearly distinguishes that site from the other observational areas, whose locations are surrounded by high and low buildings that shade them during certain periods of the day.

Table 1. Measurement points within the city of João Pessoa, Brazil. The latitudes and longitudes are shown using the Universal Transverse Mercator (UTM) geographic coordinate system. Altitudes are shown in meters.

\begin{tabular}{lcccc}
\hline Urban zones & Point & Latitude & Longitude & Altitude (m) \\
\hline Mata do Buraquinho & P01 & 9210910 & 0294473 & 18 \\
Bairro Expedicionários & P02 & 9212248 & 0295307 & 54 \\
Bairro Manaíra & P03 & 9213966 & 0297168 & 13 \\
Bairro Cabo Branco & P04 & 9212232 & 0298053 & 09 \\
Bairro Mangabeira & P05 & 9205666 & 0296918 & 50 \\
Bairro Cruz das Armas & P06 & 9210044 & 0291631 & 47 \\
Bairro Alto do Mateus & P07 & 9210524 & 0288930 & 45 \\
Bairro Centro & P08 & 9205666 & 0296918 & 50 \\
Bairro Bancários & P09 & 9209252 & 0297368 & 18 \\
\hline
\end{tabular}


Davis Weather Stations were installed at nine points throughout the city and were supplied with anemometers and thermo-hygrometers for measurements of wind speed, air temperature and relative humidity (Figure 1). The data at each measurement site were recorded hourly. The field measurements were performed at the urban and rural areas from January $5^{\text {th }}$ to March $12^{\text {th }}$, 2015 (representing the dry season) and from June $5^{\text {th }}$ to August $24^{\text {th }}, 2015$ (representing the rainy season). In addition, daily data of air temperature, relative humidity and rainfall from a typical meteorological observation station during the period of 1968-2015 were used to conduct a comprehensive temporal analysis. An analysis was performed to investigate the influence of various land use types that cause an increase in urban temperature. The percentage of land cover was obtained according to the methodology presented by Katzschner et al. (2006) for the following land cover types: (i) ceramic roof tile; (ii) asbestos roof tiles; (iii) aluminum roof tiles; (iv) body of water 1 (swimming pool); (v) body of water 2 (rivers and sea); (vi) asphalt pavement; (vii) concrete pavement; (viii) bare soil; (ix) bare soil + low vegetation; and (x) vegetation.

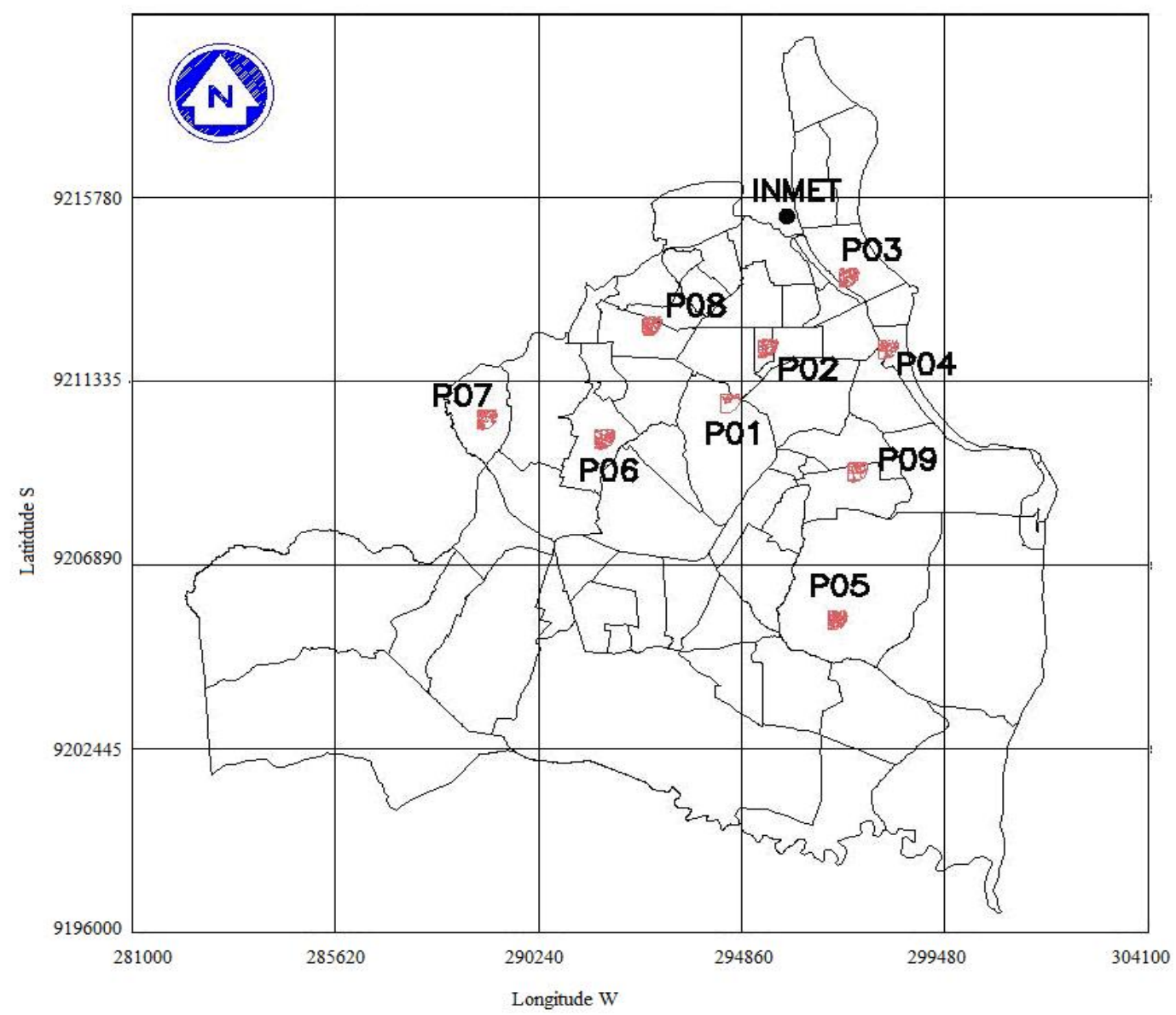

Figure 1. Locations of the measurement points and the meteorological station (INMET) within the study area. The latitudes and longitudes are shown using the Universal Transverse Mercator (UTM) geographic coordinate system. Altitudes are shown in meters.

\subsection{Comfort index}

The human discomfort level within the study area was evaluated through the effective temperature index (ET). The ET index, adapted by Li and Chan (2000), has been used worldwide to assess the effects of thermal environment on the human body as follows (Equation 1): 
$E T=37-\frac{37-T}{0.68-0.0014 R H+\frac{1}{1.7+1.4 \vartheta^{0.75}}}-0.29 T(1-0.01 R H)$

where $v$ is wind speed $\left(\mathrm{m} \mathrm{s}^{-1}\right)$ at $1.2 \mathrm{~m}$ above the ground, $\mathrm{T}$ is air temperature $\left({ }^{\circ} \mathrm{C}\right)$ and $\mathrm{RH}$ is relative humidity (\%). The ET index is suitable for open spaces and describes the extent of thermal loading under several meteorological conditions.

\subsection{Mann-Kendal test}

The World Meteorological Organization (WMO) recommends using the Mann-Kendall nonparametric test (Mann, 1945; Kendall, 1975) for assessing trends in environmental time series data. This test consists of comparing each value of a time series with the remaining values in sequential order. The number of instances for which the remaining terms are greater than that being analyzed is counted. This test is based on the statistic S, which is defined as (Equation 2):

$S=\sum_{i=1}^{n} \sum \operatorname{sign}\left(x_{i}-x_{j}\right)$

where $\mathrm{x}_{\mathrm{i}}$ to $\mathrm{x}_{\mathrm{j}}$ are the sequential data values, $\mathrm{n}$ is the length of the time series and the sign of $\left(x_{i}-x_{j}\right)$ is -1 for $\left(x_{i}-x_{j}\right)<0,0$ for $\left(x_{i}-x_{j}\right)=0$, and 1 for $\left(x_{i}-x_{j}\right)>0$. The mean E[S] and variance $\mathrm{V}[\mathrm{S}]$ of statistic $\mathrm{S}$ are given as (Equations 3 and 4):

$E[S]=0$

$\operatorname{Var}[S]=\frac{n(n-1)(2 n+5)-\sum_{p=1}^{q} t_{p}\left(t_{p}-1\right)\left(2 t_{p}+5\right)}{18}$

where $t_{p}$ is the number of equal occurrences for the $\mathrm{p}^{\text {th }}$ value, and $\mathrm{q}$ is the number of equal values. The second term represents an adjustment for equal or censored data. The standardized test statistic $\left(\mathrm{Z}_{\mathrm{MK}}\right)$ is computed as Equation 5.

$Z_{M K}=\left\{\begin{array}{l}\frac{s-1}{\sqrt{\operatorname{Var}(S)}} \text { if } S>0 \\ 0 \text { if } S=0 \\ \frac{S+1}{\sqrt{\operatorname{Var}(S)}} \text { if } S<0\end{array}\right.$

Comfort condition was established using the ET index with the objective of proposing the comfort limits valid for the study area. A thermal sensation assessment test based on responses from structured questionnaires was used for obtaining the rating scales ranging from uncomfortable to comfortable (Table 2). A similar methodology was applied by Krüger and Drach (2017) to define ranges and performance of UTCI (Universal Thermal Climate Index) in downtown Rio de Janeiro.

The presence of a statistically significant trend is evaluated using the ZMK value. This statistic is used to test the null hypothesis that no trend exists. A positive ZMK value indicates an increasing trend, whereas a negative value indicates a decreasing one. To test for either increasing or decreasing monotonic trends at the p significance level, the null hypothesis is rejected if the absolute value of ZMK is greater than ZMK1-p/2, which is obtained from a standard normal cumulative distribution table. In general, the significance levels of $p=0.01$ and 0.05 are applied. Least-squares linear regression was used to evaluate an increasing or a decreasing slope of trends in air temperature, relative humidity, wind speed, and ET index time series. Based on the trend in ET time series, it was possible to establish the scenarios for the 2020s, the 2030s, the 2040, the 2050s and the 2060s for the annual period and for the dry and the rainy seasons within the study area. The Mann-Kendall nonparametric test was used to verify the significance level of the time series trend.

\section{IPABH}

Rev. Ambient. Água vol. 13 n. 5, e2092- Taubaté 2018 
Table 2. Effective temperature index (ET) classification range adjusted to the climatic conditions of the city of João Pessoa.

\begin{tabular}{ccc}
\hline Number range & $\mathrm{ET}\left({ }^{\circ} \mathrm{C}\right)$ & Comfort conditions \\
\hline 1 & $\mathrm{ET}<24.0$ & Comfortable \\
2 & $24.0 \leq \mathrm{ET} \leq 26.0$ & Partially comfortable \\
3 & $26.0<\mathrm{ET}<28.0$ & Uncomfortable \\
4 & $\mathrm{ET} \geq 28.0$ & Very uncomfortable \\
\hline
\end{tabular}

\section{RESULTS AND DISCUSSION}

The occurrence of maximum and minimum values of the ET index and the thermal variations during both the dry and rainy seasons are summarized in Table 3 . The maximum and the minimum air temperature are not substantially different in both seasons. The thermal amplitude varies from 9.6 to $10.8^{\circ} \mathrm{C}$ during the dry season and from 9.5 to $11.5^{\circ} \mathrm{C}$ during the rainy season. During the rainy season, a temperature maximum occurs at point P08, and a minimum occurs at points $\mathrm{P} 04$ and P05. The air temperature increases rapidly in the mornings and reaches a maximum at approximately 14:00 LT (local time). The relative humidity shows an inverse relationship with temperature: the relative humidity decreases quickly from the early morning hours, and the lowest values are observed concurrent with the highest temperatures. The variability in these parameters corresponds to minimum ET values during the first hour of the day; this effect is most pronounced on January 24th during the dry season and on August 16th during the rainy season. The thermal perception commonly indicates a greater level of discomfort during the daytime in tropical regions with a maximum level of discomfort between 11:00 to 15:00 LT. Accordingly, heat stress increases until approximately 14:00 LT, although local differences occur between the seasons. Similar results were obtained by Gulyás et al. (2006), who assessed the microclimatic and human comfort conditions of the urban environment of a small city in Hungary.

The reference point (P01) has the highest density of vegetation and lowest ET during both seasons (Mata do Buraquinho). Although point P03 (Manaíra) is located near the beach, this site has the highest ET value (Table 4) due to a low percentage of type IX land cover (vegetation) and a high percentage of concrete pavement and ceramic roofing tiles (Table 5). This result does not agree with the observations of $\mathrm{Xu}$ et al. (2010), who found that a water body can effectively improve the human comfort level in the littoral zone during the hightemperature period of a hot summer day. This difference can be attributed to multiple factors, including the amount of impermeable areas with asphalt and concrete pavement, the number of high buildings and the lack of vegetation.

As illustrated by our analysis, when the nights are hot and humid throughout the dry season, uncomfortable conditions prevail during most of the daylight hours due to abundant solar radiation, which provides an additional heat load. In contrast, the interception of radiation by clouds and evaporation from wet surface during the rainy season results in a comfortable thermal sensation in the urban environment. The percentage of land cover for each experimental point is presented in Table 5. As shown in Tables 4 and 5, the ET index decreases when the amount of vegetative area increases, thereby resulting in a significant improvement in the human comfort level. Similar results were obtained by Xu et al. (2010) when they evaluated human thermal comfort near an urban water body in Shanghai, China. They found that vegetation significantly expanded the littoral comfort zone. 
Table 3. Time of occurrence of the maximum and minimum Effective Temperature index (ET) values and the thermal amplitude during the dry and rainy seasons for the study area in 2015.

\begin{tabular}{|c|c|c|c|c|c|}
\hline \multirow{3}{*}{ Points } & \multicolumn{4}{|c|}{ Effective temperature index $(\mathrm{ET})\left({ }^{\circ} \mathrm{C}\right)$} & \multirow{3}{*}{ Thermal amplitude $\left({ }^{\circ} \mathrm{C}\right)$} \\
\hline & \multicolumn{2}{|c|}{ Maximum value } & \multicolumn{2}{|c|}{ Minimum value } & \\
\hline & Date & Hour & Date & Hour & \\
\hline \multicolumn{6}{|c|}{ Dry season } \\
\hline P01 & March 10 & 11:00:00 & February 28 & 05:00:00 & 09.9 \\
\hline P02 & February 2 & 13:00:00 & February 13 & 09:00:00 & 09.7 \\
\hline P03 & February 25 & 14:00:00 & January 24 & 06:00:00 & 10.6 \\
\hline P04 & March 10 & 14:00:00 & January 24 & 05:00:00 & 10.2 \\
\hline P05 & February 25 & 11:00:00 & January 24 & 05:00:00 & 09.8 \\
\hline P06 & February 19 & 13:00:00 & January 24 & 05:00:00 & 10.7 \\
\hline P07 & February 25 & 13:00:00 & January 24 & 05:00:00 & 10.8 \\
\hline P08 & February 25 & 14:00:00 & January 24 & 05:00:00 & 09.9 \\
\hline P09 & February 25 & 13:00:00 & January 24 & 05:00:00 & 10.6 \\
\hline \multicolumn{6}{|c|}{ Rainy season } \\
\hline P01 & June 23 & 11:00:00 & August 16 & 06:00:00 & 10.6 \\
\hline P02 & June 23 & $12: 00: 00$ & August 16 & 06:00:00 & 09.8 \\
\hline P03 & August 4 & 14:00:00 & August 16 & 06:00:00 & 09.9 \\
\hline P04 & June 23 & $13: 00: 00$ & August 16 & 06:00:00 & 09.5 \\
\hline P05 & June 23 & 10:00:00 & August 16 & 06:00:00 & 09.5 \\
\hline P06 & June 7 & $15: 00: 00$ & August 16 & 06:00:00 & 10.2 \\
\hline P07 & June 23 & $13: 00: 00$ & August 16 & 05:00:00 & 10.9 \\
\hline P08 & August 4 & $13: 00: 00$ & August 16 & 06:00:00 & 11.5 \\
\hline P09 & June 21 & $13: 00: 00$ & August 16 & 06:00:00 & 10.4 \\
\hline
\end{tabular}

Table 4. Average, maximum (Max) and minimum (Min) values of air temperature, relative humidity and Effective Temperature index (ET) during the dry and rainy seasons for the study area.

\begin{tabular}{|c|c|c|c|c|c|c|c|c|c|}
\hline \multirow{2}{*}{ Points } & \multicolumn{3}{|c|}{ Air temperature $\left({ }^{\circ} \mathrm{C}\right)$} & \multicolumn{3}{|c|}{ Relative humidity (\%) } & \multicolumn{3}{|c|}{$\operatorname{ET}\left({ }^{\circ} \mathrm{C}\right)$} \\
\hline & Average & Max & Min & Average & Max & Min & Average & Max & Min \\
\hline \multicolumn{10}{|c|}{ Dry season } \\
\hline P01 & 27.2 & 28.6 & 24.1 & 81.5 & 100.0 & 70.7 & 25.7 & 26.6 & 24.2 \\
\hline P02 & 27.7 & 28.9 & 24.3 & 76.6 & 97.7 & 68.4 & 25.9 & 26.9 & 24.2 \\
\hline P03 & 28.8 & 30.1 & 24.9 & 77.1 & 98.2 & 68.2 & 26.9 & 27.9 & 24.8 \\
\hline P04 & 28.4 & 29.6 & 24.8 & 75.6 & 95.8 & 67.2 & 26.4 & 27.4 & 24.5 \\
\hline P05 & 27.7 & 28.8 & 24.5 & 78.7 & 97.6 & 70.8 & 26.1 & 27.0 & 24.3 \\
\hline P06 & 27.7 & 29.1 & 24.2 & 78.4 & 99.3 & 68.8 & 26.0 & 26.9 & 24.2 \\
\hline P07 & 27.7 & 29.0 & 24.4 & 79.1 & 98.4 & 69.3 & 26.0 & 27.0 & 24.3 \\
\hline P08 & 27.7 & 29.1 & 24.4 & 79.0 & 99.1 & 70.1 & 26.1 & 27.1 & 24.4 \\
\hline P09 & 28.2 & 29.4 & 24.6 & 75.3 & 95.6 & 65.5 & 26.2 & 27.1 & 24.4 \\
\hline Average & 27.9 & 29.2 & 24.4 & 77.9 & 98.0 & 68.7 & 26.1 & 27.1 & 24.3 \\
\hline \multicolumn{10}{|c|}{ Rainy season } \\
\hline P01 & 24.3 & 25.2 & 23.0 & 89.8 & 100.0 & 77.9 & 23.4 & 24.2 & 22.8 \\
\hline P02 & 24.9 & 26.1 & 22.7 & 86.0 & 99.6 & 74.7 & 24.0 & 25.5 & 22.7 \\
\hline P03 & 25.4 & 27.6 & 22.9 & 81.7 & 96.9 & 68.6 & 24.2 & 25.8 & 22.7 \\
\hline P04 & 25.2 & 26.8 & 22.9 & 83.5 & 97.5 & 69.5 & 24.1 & 25.6 & 22.8 \\
\hline P05 & 24.9 & 27.0 & 22.5 & 85.9 & 100.0 & 73.2 & 24.0 & 25.7 & 22.5 \\
\hline P06 & 25.1 & 26.7 & 22.7 & 85.0 & 99.2 & 72.5 & 24.0 & 25.6 & 22.7 \\
\hline P07 & 25.1 & 27.0 & 22.7 & 84.0 & 99.3 & 72.6 & 24.0 & 25.7 & 22.7 \\
\hline P08 & 25.2 & 27.3 & 22.7 & 83.9 & 98.9 & 72.8 & 24.1 & 25.5 & 22.8 \\
\hline P09 & 25.4 & 28.0 & 22.7 & 86.3 & 100.0 & 73.0 & 24.4 & 26.2 & 22.8 \\
\hline Average & 25.0 & 26.8 & 22.7 & 85.0 & 99.0 & 72.7 & 24.0 & 25.5 & 22.7 \\
\hline
\end{tabular}


Table 5. Percentages of land cover for each observation point.

\begin{tabular}{lccccccccc}
\hline Land cover & P01 & P02 & P03 & P04 & P05 & P06 & P07 & P08 & P09 \\
\hline Type I & 1.23 & 44.06 & 34.21 & 16.90 & 51.12 & 74.97 & 26.19 & 18.38 & 60.48 \\
Type II & 0.08 & 1.40 & 5.13 & 4.57 & 0.77 & 0.34 & 2.46 & 7.52 & 0.00 \\
Type III & 0.00 & 1.51 & 2.37 & 0.91 & 1.79 & 0.11 & 0.58 & 2.89 & 0.29 \\
Type IV & 1.04 & 0.34 & 0.29 & 0.56 & 0.01 & 0.00 & 0.00 & 0.07 & 0.02 \\
Type V & 0.00 & 0.00 & 0.00 & 0.00 & 0.00 & 0.00 & 0.00 & 0.00 & 0.00 \\
Type VI & 1.72 & 4.27 & 5.34 & 8.66 & 3.83 & 0.00 & 2.28 & 11.28 & 9.59 \\
Type VII & 0.00 & 24.25 & 40.00 & 29.97 & 22.12 & 0.14 & 21.23 & 39.66 & 6.26 \\
Type VIII & 11.9 & 4.49 & 4.20 & 8.14 & 8.81 & 5.87 & 36.50 & 6.37 & 7.74 \\
Type IX & 84.84 & 19.69 & 8.46 & 30.28 & 11.55 & 18.78 & 10.74 & 13.83 & 15.61 \\
\hline
\end{tabular}

Type V land cover is absent, whereas type IV cover is rare within the study area. Therefore, bodies of water do not produce positive effects on an individual's thermal perception. The quality and quantity of land cover affects the balance of energy of humans, and thus has strong implications for thermal comfort. In addition, different types of land cover have complex surface structures that determine the specific microclimatic qualities of an environment. The effect of vegetation on microclimates during the daytime results from the reduced penetration of solar radiation to the ground and through the walls due to partial shading (Hassaan and Mahmoud, 2011).

Asphalt (Type VI) and concrete (Type VII) pavement produced microclimate effects, and therefore contributed to an increase in the ET at points P03, P04 and P05. These pavement materials absorb solar and infrared radiation and dissipate a portion of the accumulated heat to the atmosphere via convective and radiative processes, thereby increasing the ambient temperature (Akbari et al., 2001). João Pessoa is a coastal city with a warm and humid climate, and therefore building-system interactions play a significant role in thermal comfort. This study demonstrated that areas with a high density of ceramic roofing tiles and asphalt pavement have the highest temperatures and ET values, which are related to the thermal properties of these structures. In contrast, the most comfortable areas in the city were closest to vegetated areas, which had comfort levels similar to those of the rural area (Mata do Buraquinho). According to Table 4, the average air temperature, the relative humidity and the ET index at each analyzed point for both seasons throughout 2015 showed thermal perception ratios that were clearly outside the comfort zone, according to the adjusted ET range. The exception to this trend was the reference point (rural area) during the rainy season. The minimum values of the ET index in the mornings were in the comfortable and partially comfortable ranges during the rainy and dry seasons, respectively. However, in the afternoons, the maximum ET values were uncomfortable during the dry season and varied from partially comfortable to uncomfortable during the rainy season.

Evaluation of the ET values during the dry season shows that the thermal comfort in most cases was significantly reduced relative to the rainy season; i.e., the comfort level changed from a superior to inferior range at all monitored points according to the classifications using the adjusted ET. The minimum ET values at point P01 tended to be slightly higher than at point P02 during the rainy season, although these values were equal in the dry season. However, appreciable differences in the ET index values during the dry season were, respectively, $6.1 \%$ and $6.6 \%$ higher than those during rainy season. In general, the relative humidity was high throughout the seasons. The results also show that difference in the ET between the measuring points was as high as $7.5 \%-8.7 \%$ due to the different abundances of permeable and impermeable materials. 
Complex urban environments can result in very different and often extreme comfort sensations even within short distances (Gulyás et al., 2006). These differences are statistically significant according to the Mann-Kendall test $(\mathrm{p}<0.05)$. The air temperature increased between the 1980s and the 2010s, which corresponds to a period of rapid urbanization in this city. These trends were used to determine future scenarios of thermal comfort conditions and to compare these predictions to the comfort limits specified by current standards. These findings are particularly important because specific meteorological conditions, including high temperatures, low cloud cover, and low average wind speeds, tend to intensify the heat island effect. To quantify the bioclimatic conditions throughout the study area, air temperature and relative humidity trends from meteorological stations close to an urban area were used to assess the impact of urban development on thermal stress. Figure 2 shows the trends in air temperature and relative humidity in the study area for the period 1968-2015. Air temperature shows an increasing trend of $0.34^{\circ} \mathrm{C} /$ decade, whereas relative humidity shows a decreasing trend of $0.49 \% /$ decade, as calculated using annual mean data.

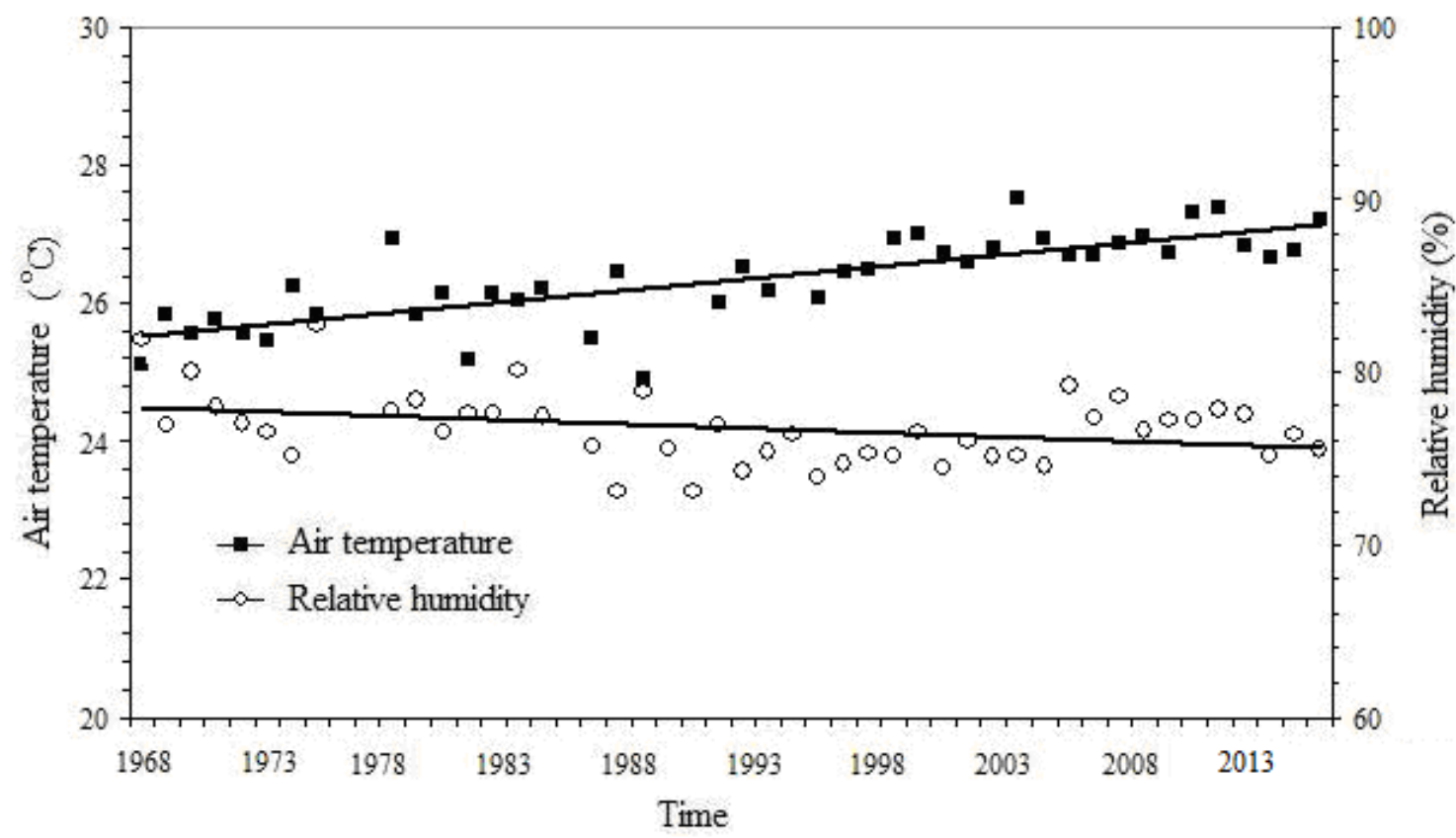

Figure 2. Trends in air temperature and relative humidity in the study area for the period of 1968-20115.

Trend in wind speed in João Pessoa during analyzed periods is shown in Figure 3. The seasonal wind speed pattern in the study area is increasing with a trend of $0.15 \mathrm{~ms}^{-1} / \mathrm{decade}$. This trend is statistically significant according to the Mann-Kendall test at the $5 \%$ confidence level. Wind speed values range from a minimum of $1.3 \mathrm{~ms}^{-1}$ to a maximum of $3.80 \mathrm{~ms}^{-1}$ with average \pm standard deviation of $2.91 \pm 0.61 \mathrm{~ms}^{-1}$. When discussing the effects of urban design and meteorological parameters on thermal comfort for pedestrians at street level, Kleerekoper et al. (2017) observed that wind is among the four main thermal comfort indicators, and is therefore an important parameter to be used in any urban climate index. Using the MannKendall test for analyzing climate trends on the extreme winds in Brazil, Pes et al. (2017) observed that trends in minimum wind speed series are not conclusive because they show disparate results between homogeneous regions.

Figure 3 also shows that there is no trend in the wind data if we consider only the 19792008 timeframe and a significant fall in the wind speed trend post 2008. This decrease can be linked objectively to the urban expansion in the last years. Silva (2004) found for João Pessoa an increasing trend in air temperature of $0.025^{\circ} \mathrm{C} /$ year and a decreasing trend in relative

\section{IPABH}

Rev. Ambient. Água vol. 13 n. 5, e2092- Taubaté 2018 
humidity of $0.10 \% / y e a r$, both statistically significant at $\mathrm{p}<0.01$ level. He also observed an increasing trend in Class A pan evaporation and reference evapotranspiration, which are indicative of a decreasing trend in wind speed. The results of the present study agree with those reported by Silva (2004). When analyzing the spatiotemporal impact of land use and land cover changes on urban heat islands in Maranhão State, Brazil, Silva et al. (2018) observed that many areas experienced extensive urbanization over the 16-year study period, which resulted in the loss of green spaces and increased urban heat island.

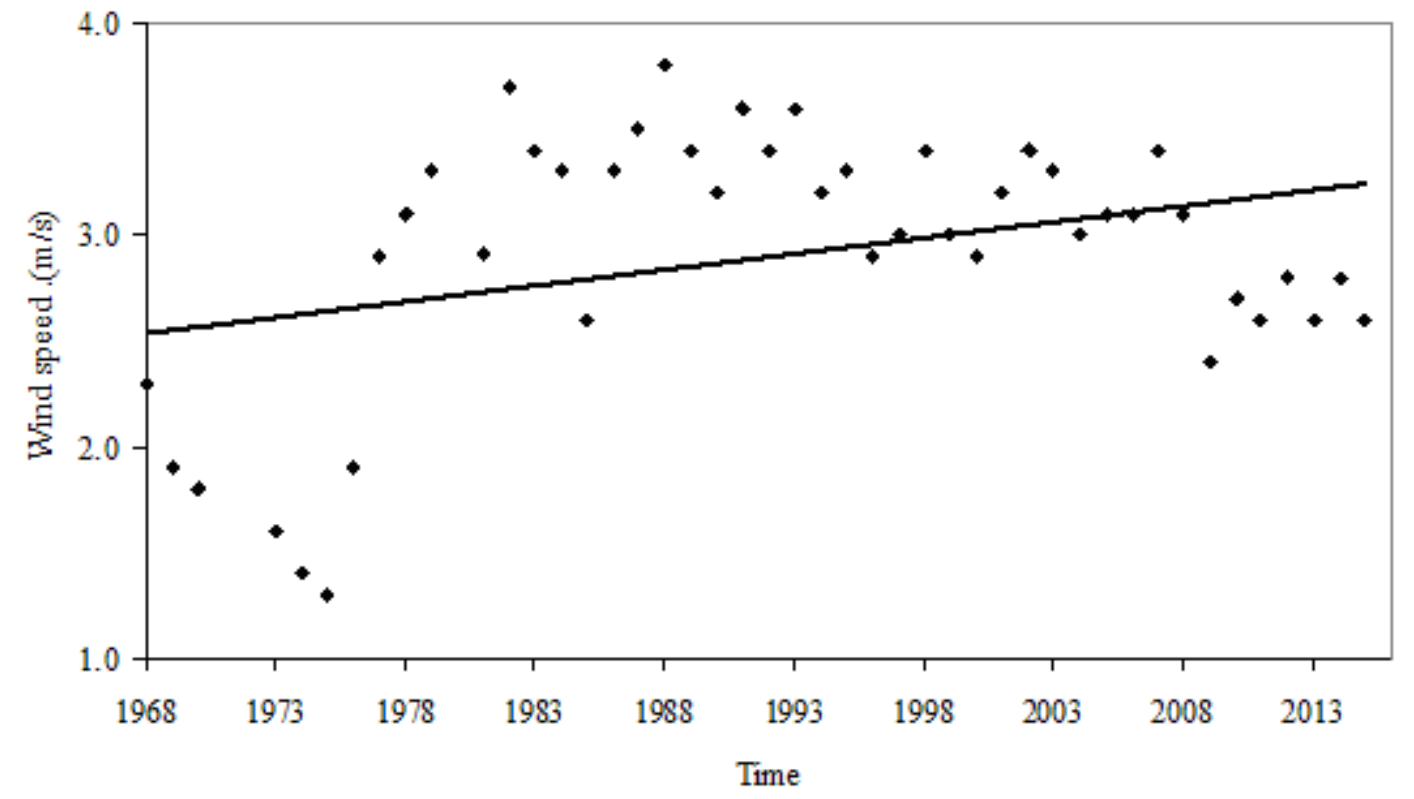

Figure 3. Trends in air wind speed in the study area for the period of 1968-20115.

The spatial distribution of the human thermal comfort level in João Pessoa for current climate conditions and for the 2020s, the 2030s, the 2040s, the 2050s and the 2060s are depicted for both the dry and rainy seasons in Figures 4 and 5, respectively. It is apparent that there is a large discrepancy in the thermal sensations between the two seasons. For the current weather conditions, the areas surrounding point P01 are partially comfortable, whereas the remainder of the city is uncomfortable during the dry season (Figure 4A). Except for the comfortable level of the reference area (point P01), the city is partially comfortable during the rainy season (Figure 5A). In the coastal area, large differences in the air temperature and ET index occur during the dry season relative to the rainy season. For the dry season, results for the scenarios from the 2020s to the 2050s indicate that the entire city is uncomfortable during the dry season due to a sensation of heat that varies between approximately $27^{\circ} \mathrm{C}$ (point P01) and $30^{\circ} \mathrm{C}$ (point P03). For the scenario in the 2060s (Figure 4F), points P03 and P04 became very uncomfortable, with air temperatures in the range $28.9-30.5^{\circ} \mathrm{C}$, and the remaining area is uncomfortable. Thermal conditions during the rainy season will tend to be less rigorous for the scenarios from the 2020s to the 2050s. Because building-system interactions play a significant role in thermal perception, it is reasonable that points P02 and P03 show a high discomfort level. The intensity of external heat loads in these areas is more dependent on the solar radiation and orientation of the building (east-west or north-south) than on wind speed. Although wind is an important factor for mitigating the heat stress of an urban area, the obstacles created by high-rise buildings prevent the flow of wind from the ocean.

The simulated ET index also revealed significant changes in human thermal comfort for the rainy season, particularly in the coastal area, for the 2060s scenario. The reference point (Mata do Buraquinho) changes from comfortable to partially comfortable during this season, 
whereas the coastal area (points P03, P04 and P09) changes from partially comfortable to uncomfortable. This indicates an overall difference of 5.5\% and 6.4\% during dry and rainy seasons, respectively. The temperature in the coastal area is primarily influenced by buildings and asphalt pavement that trap solar radiation. In contrast, the air temperature at the reference area is influenced by vegetation that maintains a temperature lower than that in the other areas of the city as a consequence of evapotranspiration by abundant vegetation. The relatively comfortable areas within the city for both current weather conditions and future scenarios are those closer to vegetation. Point P02 is the second-most comfortable area among the measuring points, which may be attributable to the green areas surrounding the reference point. In summary, the area of comfortable conditions surrounding point P01 appears during dry and rainy seasons due to evapotranspiration by native vegetation, which results in lower temperatures in comparison to other points in the city.

Inversely, uncomfortable conditions near point P03 are caused by heat that is accumulated by the impervious surfaces or building materials (e.g., concrete and asphalt) during the day. This result agrees with the observations of Hassaan and Mahmoud (2011) who analyzed the microclimatic and human comfort conditions in an urban park in hot and arid regions. They documented that the thermal requirements of people and the qualities of the local climate should be carefully considered when designing the landscapes of urban parks in hot and arid regions. The temperatures were found to be highest near the coastal area, and the temperature gradient increases from the coastal area towards the reference point. The horizontal surface temperature gradient can be used to determine the cooling effect of vegetation relative to the urban effect. Air temperature has been increasing at a rate of $0.034^{\circ} \mathrm{C} /$ year during the last 48 years with predicted values as high as $30.5^{\circ} \mathrm{C}$ in the $2060 \mathrm{~s}$. The maximum predicted value is only $28.9^{\circ} \mathrm{C}$ at the reference point, in agreement with the presence of vegetation. There is a sharp increase in the ET values at point P03 when the ET reaches very uncomfortable conditions in the 2050s, whereas the remaining area has uncomfortable conditions during the dry season.

The highest recorded air temperature at points P03, P04 and P09 are attributable to different types of cover, such as aluminum roofing tiles, asphalt pavement and concrete pavement. A major problem associated with the use of those materials in warm weather is that they absorb and retain enormous amounts of heat, which leads to an increase in air temperature. Therefore, the level of human thermal comfort has been increasing throughout these areas due to the substitution of vegetation for building materials. These data indicate that the range of ET index corresponds to a thermal sensation between uncomfortable in the dry season and comfortable/partially comfortable in the rainy season for the current weather conditions. This study indicates that physiological responses are determined primarily by changes in air temperature.

Air temperature (Figure 6) is also significantly different in the dry season relative to the rainy season along the coastal area, which affects the heat stress in the urban area. The air temperature varies between $24.6-25.5^{\circ} \mathrm{C}$ during the rainy season (Figure 6A) and varies between $27.2-28.8^{\circ} \mathrm{C}$ among the measurement points during the dry season (Figure 6B). The small differences in temperatures can be explained by the relatively short distances between the measuring points. However, large differences in relative humidity are observed among the measurement points; e.g., the relative humidity varies by $7.8 \%$ and $9.9 \%$ during dry and rainy seasons, respectively. 


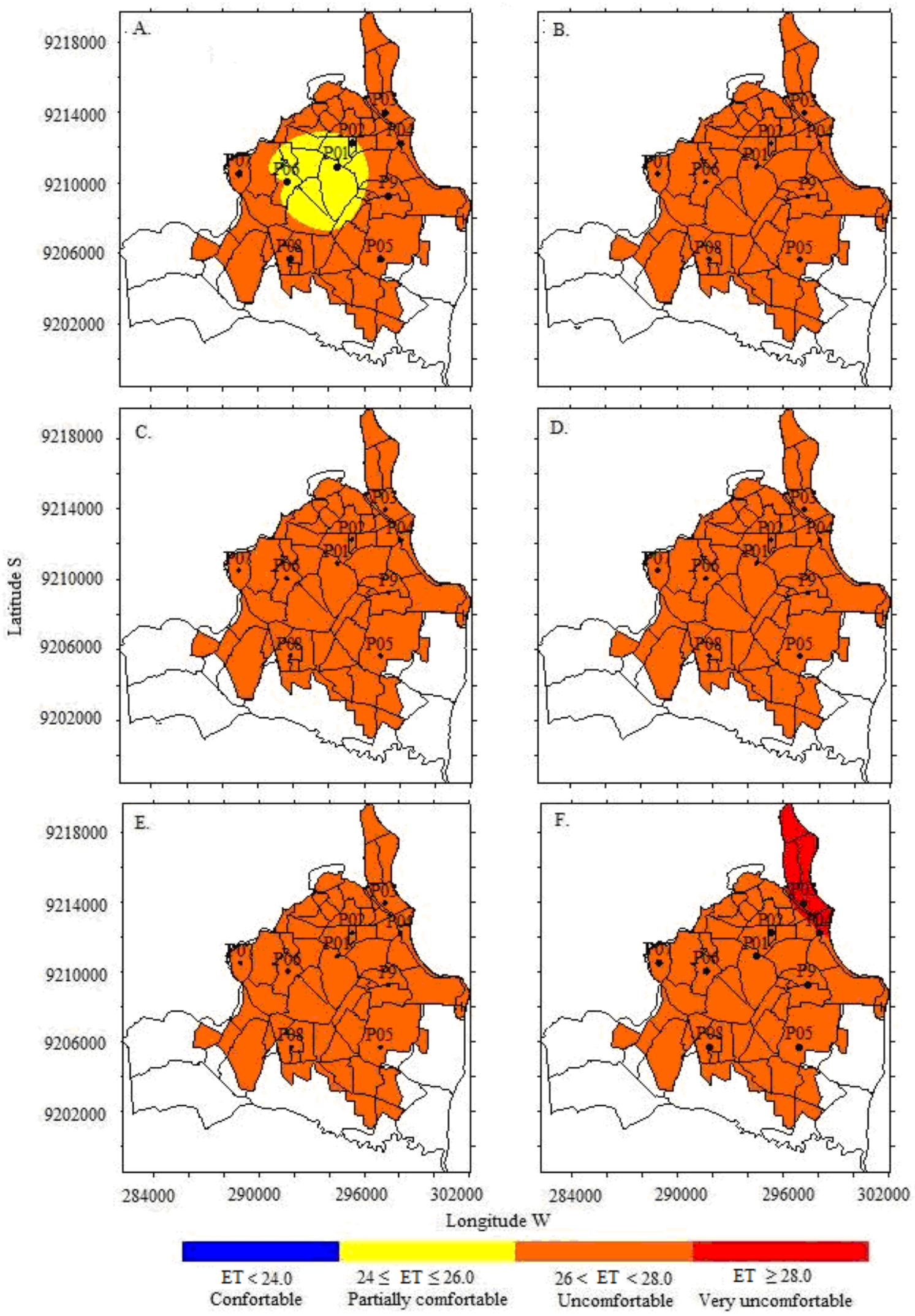

Figure 4. Spatial distribution of human comfort levels in 2010s (A) and in scenarios for 2020s (B), 2030s (C), 2040s (D), 2050s (E) and 2060s (F) during the dry season within the study area. Latitudes and longitudes are shown using the Universal Transverse Mercator (UTM) geographic coordinate system. 


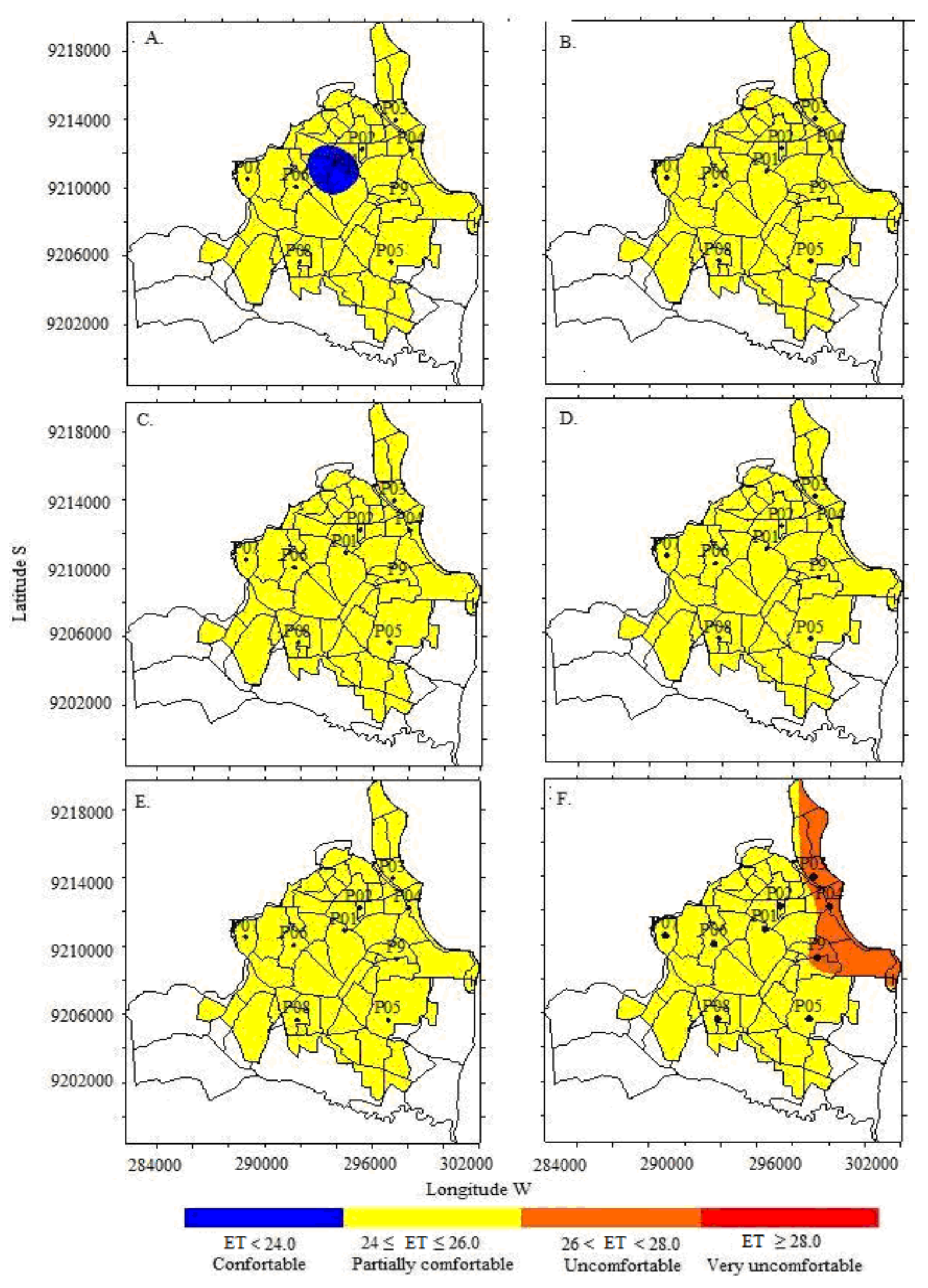

Figure 5. Spatial distribution of human comfort levels in 2010s (A) and in scenarios for 2020s (B), 2030s (C), 2040s (D), 2050s (E) and 2060s (F) during the rainy season within the study area. Latitudes and longitudes are shown using the Universal Transverse Mercator (UTM) geographic coordinate system.

\section{IPABH}




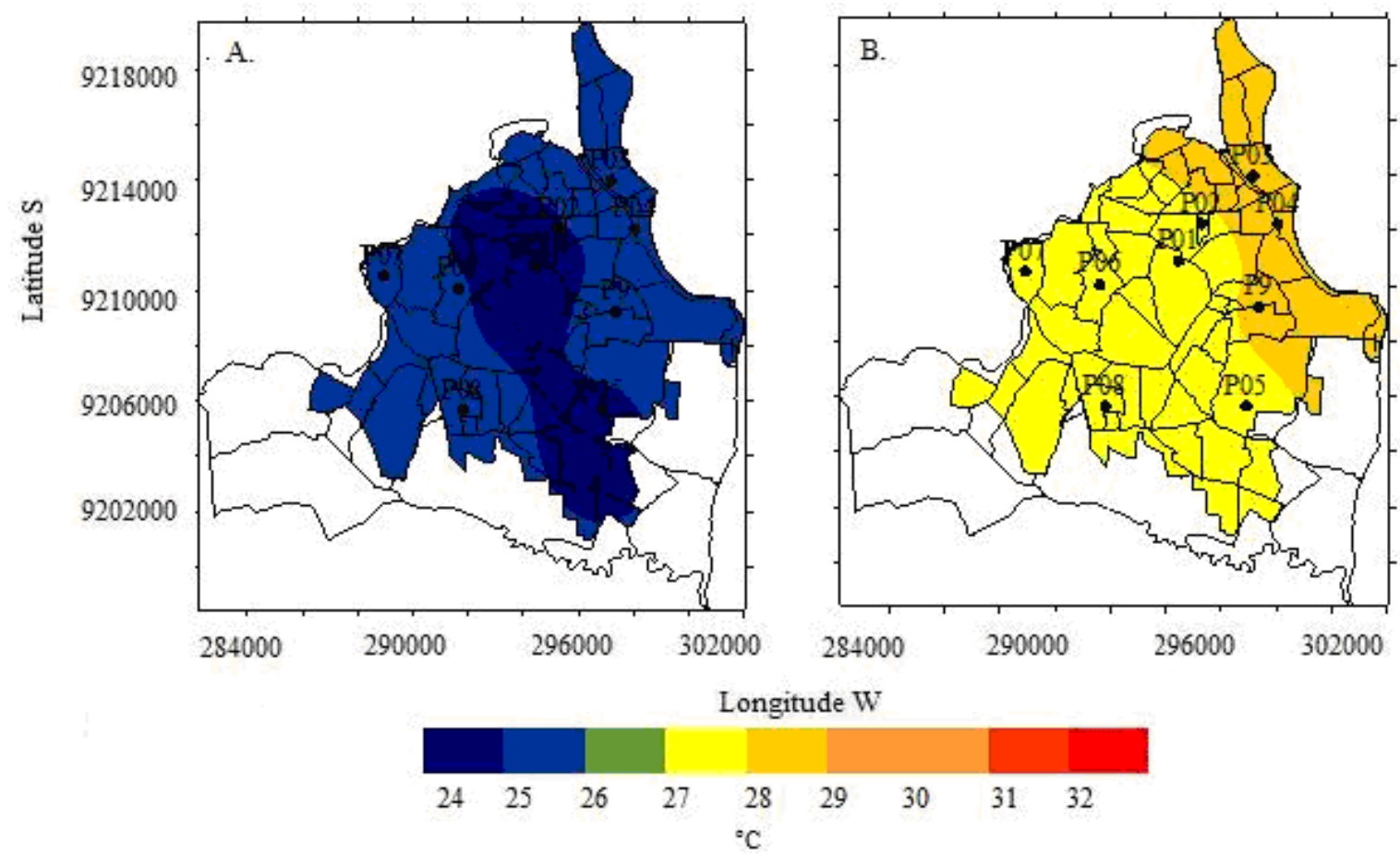

Figure 6. Spatial distribution of air temperatures in 2015 during the rainy (A) and dry (B) seasons within the study area.

Although points P03 and P04 are located near the coastal zone, they have an uncomfortable condition according to the adjusted ET index. The combined effects of high temperature, high moisture content and changes in the urban landscape can explain these results. Another reason for the high thermal conditions is that the surface materials in that zone have a high albedo, which reflects a large amount of radiation to the surrounding objects; that area is also not surrounded by any vegetation. Although studies have shown that areas $10-20 \mathrm{~m}$ from the water's edge show the greatest improvement in thermal comfort (Xu et al., 2010) changes in the biodiversity and aesthetics of urban landscapes in littoral areas can have a synergistic effect, thereby reducing the effects of the water body on human thermal comfort.

\section{CONCLUSIONS}

This paper has studied the bioclimatic conditions for future scenarios for João Pessoa, a humid tropical city located in Brazil. This study indicates that physiological responses are determined primarily by changes in air temperature. Wind speed can be considered a valuable climatic variable for purpose of urban climate studies. Land cover changes produce effects on evaporation/evapotranspiration and therefore on human comfort level. There is a clear increasing trend in outdoor temperatures and decreasing trend in relative humidity levels in the study area. Current and future environmental conditions are likely to shift towards a warmer atmosphere due to urbanization processes. The effects of these changes on people will be more pronounced during the dry season when the human thermal comfort will change from comfortable to very uncomfortable throughout most of the city. The projection of climate variables from 2010 to 2060 in the hottest area of the city demonstrate a large air temperature increase of up to $2^{\circ} \mathrm{C}$, whereas the relative humidity is reduced by up to $2.5 \%$. Highly uncomfortable conditions are predicted for the period of 2050 to 2060 throughout João Pessoa city. 


\section{REFERENCES}

AKBARI, H.; POMERANTZ, M.; TAHA, H. Cool surfaces and shade trees to reduce energy use and improve air quality in urban areas. Solar Energy, v. 70, n. 1, p. 295-310, 2001.

GULYÁS, A.; UNGER, J.; MATZARAKIS, A. Assessment of the microclimatic and human comfort conditions in a complex urban environment: Modeling and measurements. Building and Environment, v. 41, p. 1713-1722, 2006.

HAN, J.; YANG, W.; ZHOU, J.; ZHANG, G.; ZHANG, Q.; MOSCHANDREAS, D. J. A. Comparative analysis of urban and rural residential thermal comfort under natural ventilation environment. Energy Building, v. 41, p. 139-145, 2009.

HASSAAN, A.; MAHMOUD, A. Analysis of the microclimatic and human comfort conditions in an urban park in hot and arid regions. Building and Environment, v. 46, p. 26412656, 2011.

JUSUF, S. K.; WONG, N. H.; HAGEN, E.; ANGORRO, R.; HONG, Y. The influence of land use on the urban heat island in Singapore. Habitat International, v. 31, p. 232-242, 2007.

KATZSCHNER, L.; BOSCH, U.; RÖTTGEN, M. Behaviour of people in open spaces in dependence of thermal comfort conditions. In: CONFERENCE ON PASSIVE AND LOW ENERGY ARCHITECTURE, 23., 2006, Proceedings... Genève: Université de Genève, 2006.

KENDALL, M. G. Rank correlation measures. London: Charles Griffin, 1975. 220p.

KLEEREKOPER, L.; TALEGHANI, M.; VAN DEN DOBBELSTEEN, A.; HORDIJK, T. Urban measures for hot weather conditions in a temperate climate condition: A review study. Renewable and Sustainable Energy Reviews, v. 75, p. 515-533, 2017.

KOLOTRONI, M.; GIRIDHARAN, R. Urban heat island intensity in London: an investigation of the impact of physical characteristics on changes in outdoor air temperature during summer. Solar Energy, v. 82, p. 986-988, 2008.

KRÜGER, E. L.; MINELLA, F. O.; RASIA, F. Impact of urban geometry on outdoor thermal comfort and air quality from field measurements in Curitiba, Brazil. Building and Environment, v. 46, p. 621-634, 2011.

KRÜGER, E. L.; DRACH, P. R. C. Interferências do fator cor da pele na percepção térmica de transeuntes. Ambiente Construído, v. 17, n. 1, p. 83-96, 2017.

LI, P.W.; CHAN S. T. Application of a weather stress index for alerting the public to stressful weather in Hong Kong. Journal of Climate and Applied Meteorology, v. 7, p. 369-375, 2000.

LOBACCARO, G.; CARLUCCI, S.; CROCE, S.; PAPARELLA, R.; FINOCCHIARO, L. Boosting solar accessibility and potential of urban districts in the Nordic climate: A case study in Trondheim. Solar Energy, v. 149, p. 347-369, 2017.

MANN, H. B. Econometrica. The econometric society, v. 13, p. 245-259, 1945.

MATZARAKIS, A.; RUTZ F.; MAYER, H. Model-ling Radiation fluxes in simple and complex environments - Basics of the RayMan model. International Journal of Biometeorology, v. 54, p. 131-139, 2010. 
MEMON, R. A.; LEUNG, D. Y. C.; CHUNHO, L. A review on the generation, determination and mitigation of Urban Heat Island. Journal of Environmental Sciences, v. 20, p. 120128, 2008.

PES, M. P.; PEREIRA, E. B.; MARENGO, J. A.; MARTINS, F. R.; HEINEMANN, D.; SCHMIDT, M. Climate trends on the extreme winds in Brazil. Renewable Energy, v. 109, p. 110-120, 2017.

RAFAEL, S.; MARTINS, H.; MARTA-ALMEIDA, M.; SÁ, E.; COELHO, S.; ROCHA, A. et al. Quantification and mapping of urban fluxes under climate change: Application of WRF-SUEWS model to Greater Porto area (Portugal). Environmental Research, v. 155, p. 321-344, 2017.

ROBAA, S. M. Thermal Human Comfort in Egypt. International Journal of Meteorology, v. 283, p. 359-371, 2003.

SALVATI, A.; ROURA, H. C.; CECERE, C. Assessing the urban heat island and its energy impact on residential buildings in mediterranean climate: Barcelona case study. Energy and Buildings, v. 146, p. 38-54, 2017.

SILVA, V. P. R. On climate variability in Northeast of Brazil. Journal of Arid Environments, v. 58, p. 575-596, 2004.

SILVA, V. P. R.; SOUSA, F. A. S.; CAVALCANTI, E. P.; SOUZA, E. P.; SILVA, B. B. Teleconnections between sea-surface temperature anomalies and air temperature in northeast Brazil. Journal of Atmospheric and Solar-Terrestrial Physics, v. 68, p. 781792, 2006.

SILVA, V. P. R.; AZEVEDO, P. V.; BRITO, R. S.; CAMPOS, J. H. B. C. Evaluating the urban climate of a typically tropical city of northeastern Brazil. Environmental Monitoring Assessment, v. 161, n. 1, p. 45 - 59, 2010.

SILVA, J. S.; SILVA, R. M.; SANTOS, C. A. G. Spatiotemporal impact of land use/land cover changes on urban heat islands: A case study of Paço do Lumiar, Brazil. Building and Environment, v. 136, p. 279-292, 2018.

TONG, H.; WALTON, A.; SANG, J.; CHAN, C. L. Numerical simulation of the urban boundary layer over the complex terrain of Hong Kong. Atmospheric Environment, v. 9, n.1, p. 3549-3563, 2005.

TSELIOU, A.; TSIROS, I. X.; LYKOUDIS, S.; NIKOLOPOULOUM, M. An evaluation of three biometeorological indices for human thermal comfort in urban outdoor areas under real climatic conditions. Building and Environment, v. 45, p. 1346-1352, 2010.

VEREMCHUK, L. V.; YANKOVA, V. I.; VITKINA, T. I.; NAZARENKO, A. V.; GOLOKHVAST, K. S. Urban air pollution, climate and its impact on asthma morbidity. Asian Pacific Journal of Tropical Biomedicine, v. 6, p. 76-79, 2016.

YU, C.; HIEN, W. N. Thermal benefits of City Parks. Energy and Buildings, v. 38, p. 105120, 2006.

XU, J.; WEI, Q.; HUANG, X.; ZHU, X.; LI, G. Evaluation of human thermal comfort near urban waterbody during summer. Building and Environment, v. 45, p. 1072-1080, 2010.

WU, J.; FRANZÉN, D.; MALMSTRÖM, M. E. Nutrient flows following changes in source strengths, land use and climate in an urban catchment, Råcksta Träsk in Stockholm,Sweden. Ecological Modelling, v. 338, p.69-77, 2016. 


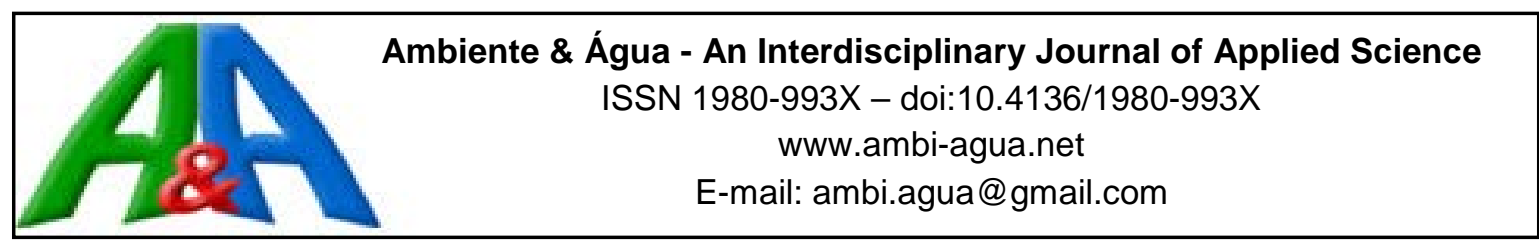

\title{
Cost of charging for water use in the Brazilian Cerrado hydrographic basin
}

ARTICLES doi:10.4136/ambi-agua.2238

Received: 07 Feb. 2018; Accepted: 27 Aug. 2018

\author{
Kalesson Martins Alencar ${ }^{1 *}$; Michel Castro Moreira ${ }^{2}$; Demetrius David da Silva ${ }^{3}$ \\ ${ }^{1}$ Universidade Federal do Oeste da Bahia (UFOB), Barreiras, BA, Brasil \\ Coordenadoria de Gestão Administrativa (CGA). E-mail: kalesson.alencar@gmail.com \\ ${ }^{2}$ Universidade Federal do Oeste da Bahia (UFOB), Barreiras, BA, Brasil \\ Centro das Ciências Exatas e das Tecnologias (CCET). E-mail: michelcm@ufob.edu.br \\ ${ }^{3}$ Universidade Federal de Viçosa (UFV), Viçosa, MG, Brasil \\ Departamento de Engenharia Agrícola (DEA). E-mail: demetrius@ufv.br \\ ${ }^{*}$ Corresponding author
}

\begin{abstract}
This study analyzed the relative cost of charging for water use with respect to water users' production costs in the Grande River Basin, located in the Brazilian Cerrado, considering the principal charging methods existing in Brazil. The study was developed based on: the rights of use grant data surveys pertaining to water resources and the classification of bodies of water into usage classes; a simulation of charging for water use through various methods; and an analysis of the relative cost of charges on the production cost of the water users. The charging methods used by the following were studied: the Committee of the Basin of River Paraíba do Sul (CEIVAP), the Committee of Basins of Piracicaba, Capivari and Jundiaí Rivers (PCJ), the São Francisco River Basin Committee (CBHSF) and the Doce River Basin Committee (CBHDOCE). The study verified that irrigated agriculture is the sector that uses the most water, representing $46.4 \%$ of the outflow granted in the basin. Considering the different charging methods, the collection in the basin of the Grande River potentially allows for investments of US\$ 1.2 million (PCJ), US\$ 920,000 (CEIVAP), US\$ 426,000 (CBH-DOCE), or US\$ 297,000 (CBHSF) in this region, leading to average relative costs of $0.68 \%$ (irrigation), $0.28 \%$ (human) and $0.08 \%$ (industry). For this reason, there is the possibility of implanting charges for water use in the Grande River Basin, with either the CEIVAP's or PCJ's method appearing to be the most suitable, given that the parameters of these mechanisms are in line with existing activities in the basin.
\end{abstract}

Keywords: Brazilian Cerrado, water price, water resources management.

\section{Custo da cobrança pelo uso da água em bacia hidrográfica do Cerrado Brasileiro}

\section{RESUMO}

Este trabalho teve por objetivo analisar o custo relativo da cobrança pelo uso da água em relação aos custos de produção dos usuários na bacia do rio Grande, localizada no Cerrado Brasileiro, considerando os principais mecanismos de cobrança existentes no Brasil. O trabalho foi desenvolvido a partir do levantamento dos dados de outorga dos direitos de uso de recursos 
hídricos e de enquadramento dos corpos de água em classes de uso; da simulação da cobrança pelo uso da água utilizando diferentes mecanismos de cobrança; e da análise do custo relativo da cobrança no custo de produção dos usuários de água. Foram estudados os mecanismos de cobrança do Comitê para Integração da Bacia Hidrográfica do rio Paraíba do Sul (CEIVAP), Comitê da Bacia Hidrográfica dos rios Piracicaba, Capivari e Jundiaí (PCJ), Comitê da Bacia Hidrográfica do rio São Francisco (CBHSF) e Comitê da Bacia Hidrográfica do rio Doce (CBHDOCE). O levantamento dos dados de outorga permitiu verificar que a agricultura irrigada é o setor que mais utiliza água, representando $46.4 \%$ da vazão outorgada na bacia. A cobrança na bacia do rio Grande, considerando os diferentes mecanismos de cobrança, poderia permitir investimentos nessa região na ordem de US\$ 1.2 milhão (PCJ), US\$ 920 mil (CEIVAP), US\$ 426 mil (CBH-DOCE), ou de US\$ 297 mil (CBHSF), gerando impactos econômicos médios de $0.68 \%$ (irrigação), $0.28 \%$ (humano) e $0.08 \%$ (indústria). Deste modo, há possibilidade de implantação da cobrança pelo uso da água na bacia do rio Grande, sendo o mecanismo do CEIVAP ou o do PCJ os mais adequados, haja vista os parâmetros destes mecanismos estarem alinhados às atividades existentes na bacia.

Palavras-chave: Cerrado Brasileiro, gestão de recursos hídricos, preço da água.

\section{INTRODUCTION}

Demands from different users have been causing conflicts over water use worldwide (Garcia-Valiñas et al., 2013; Nazer et al., 2010). The main reason for these disputes lies in water's qualitative and quantitative limitations (Wolf et al., 2005), which has spurred many countries to review and or introduce legislation related to the management of water resources (Veiga and Magrine, 2013).

Among the management instruments provided for in the National Water Resources Policy (NWRP), established by Law No.9.433/1997 in Brazil, charging for using water resources seeks to: "recognize water as an economic property and make users aware of its real value; to stimulate the rationalization of water use; and to get financial resources for subsidizing the programs and interventions covered in the plans for water resources” (Brazil, 1997).

The attainment of financial resources by means of charging enables interventions in the basin that can provide improvements in the quality and amount of water, as well as reducing environmental degradation. Ploeg and Sommerfeld (2011) explain that charging is an effective tool to encourage the conservation and protection of water resources, whereas Johnson et al. (2002) point out that investment in the sustainable management of the basin can be significantly lower than the expenses necessary to obtain new forms of water supply or treatment.

Charging is already enforced in various river basins across Brazil, such as the Paraíba do Sul River; Piracicaba, Capivari and Jundiaí Rivers; São Francisco and Doce Rivers, which use the main existing charging methods in Brazil. They were established, respectively, by the Committee for the Integration of the Hydrographic Basin of River Paraíba do Sul (CEIVAP), Committee of Hydrographic Basins of Piracicaba, Capivari and Jundiaí Rivers (PCJ), São Francisco River Hydrographic Basin Committee (CBHSF) and Doce River Hydrographic Basin Committee (CBH-DOCE).

In 2015, Brazil collected approximately US\$ 92.3 million with the from charges for water use from river basins (ANA, 2016). This situation demonstrates the involvement of water basin users, as defaults did not exceed 10\% of the amount charged in 2014.

Charging for using water resources is highly important in places where there is a high demand on water use, such as occurs in the Grande River Basin, located in the western part of the state of Bahia, in a region characterized by Cerrado Biome. This biome is considered a biodiversity hotspot (Araújo et al., 2012), and with an area of approximately 2 million 
kilometers (Klink and Machado, 2005), it is the second largest in Brazil (Souza et al., 2016). The expansion of agribusiness in the region has accelerated the destruction of this biome, because more than half of its area has been transformed into pastures and grain crops, among other uses (Klink and Machado, 2005), and it has also been threatened by the expansion of sugar cane (Carvalho et al., 2009).

According to AIBA (2015), Western Bahia is renowned for its agribusiness strength, having produced 7.4 million tons of agricultural products in 2014-2015 in a 2.3-million-hectare area, especially soybeans, maize and cotton. The region has a predominance of withdrawal for irrigation flows compared to other uses, representing more than $60 \%$ of the total demand (ANA, 2013).

Given the importance of the Grande River Basin, most notably through conservation needs for the Cerrado Biome, its intensely irrigated agriculture and the hydroelectric potential of the region, this study sought to analyze the relative cost of charging for water use with respect to water users' production costs in the Grande River Basin, taking the main charging methods existing in Brazil into account, aiming to provide a basis for the implementation of this management tool in order to contribute to the multiple and rational use of water.

\section{MATERIALS AND METHODS}

\subsection{Study area}

In order to analyze the relative cost of charging for water use and taking the main charging methods existing in Brazil into account, this work was carried out in the Grande River Basin, Western State of Bahia, in a region of the Cerrado Biome (Figure 1).

The Grande River Basin has an area of $78,500 \mathrm{~km}^{2}$ and corresponds to $13.9 \%$ of the State of Bahia (Almeida et al. 2014). The Grande River produces the third largest water source flowing into the São Francisco River Basin (Feitosa and Santos, 2016; Pereira et al., 2007); however, there have been conflicts over water use. Thus, proper management of its water resources is required (Moreira and Silva, 2010).

The basin comprises 17 municipalities in Western Bahia where the climate ranges from humid to semi-arid (INEMA, 2014), and the Cerrado is its predominant biome (Santos and Castro 2016). As per Passo et al. (2010), the introduction of agriculture in the Cerrado of Bahia, notably in Western Bahia, has effected a change in the economic, political and geographic profile of the region - a milestone in the Brazilian economic scene.

\subsection{Grants and guidelines}

Considering that the Brazilian legislation only allows charging for water use subject to the granting instrument, the Institute for the Environment and Water Resources (INEMA) has provided the Grande River Basin grants data, issued up to September 2015, as INEMA is the managing agency of water resources for the State of Bahia.

The waters from rivers are classified under CONAMA's resolution No. 357/2005, according to the quality required for their preponderant uses (special, I, II, III or IV classes) (CONAMA, 2005). This classification is required in order to meet the most demanding uses in each section of the basin, and it is fundamental to understand the uses and quality needed before implementing charges

The framework class of the rivers from the Grande River Basin was provided by the São Francisco River Hydrographic Basin Committee (CBHSF), in its Water Resources Plan (ANA et al., 2004), since the Grande River Basin is a sub-basin of the São Francisco River Basin (Figure 1).

\section{IPABH}



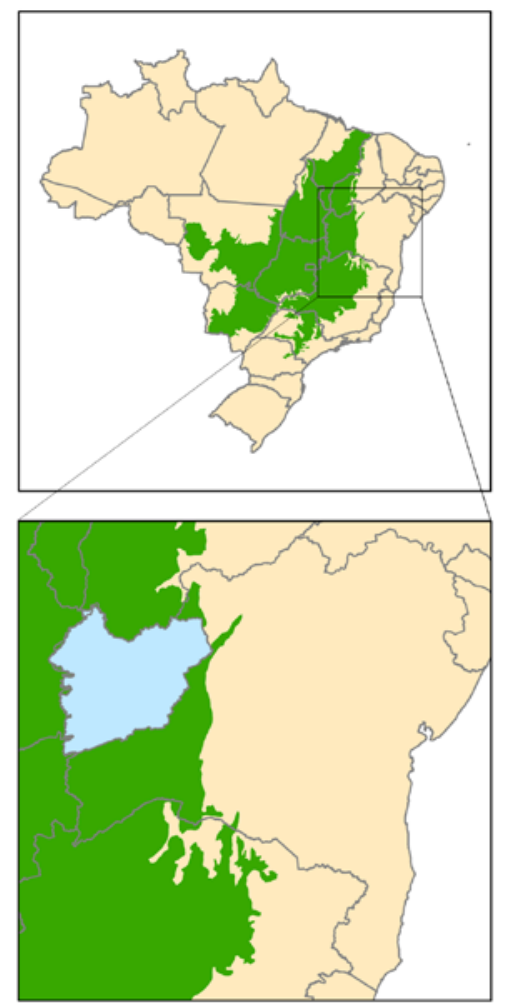

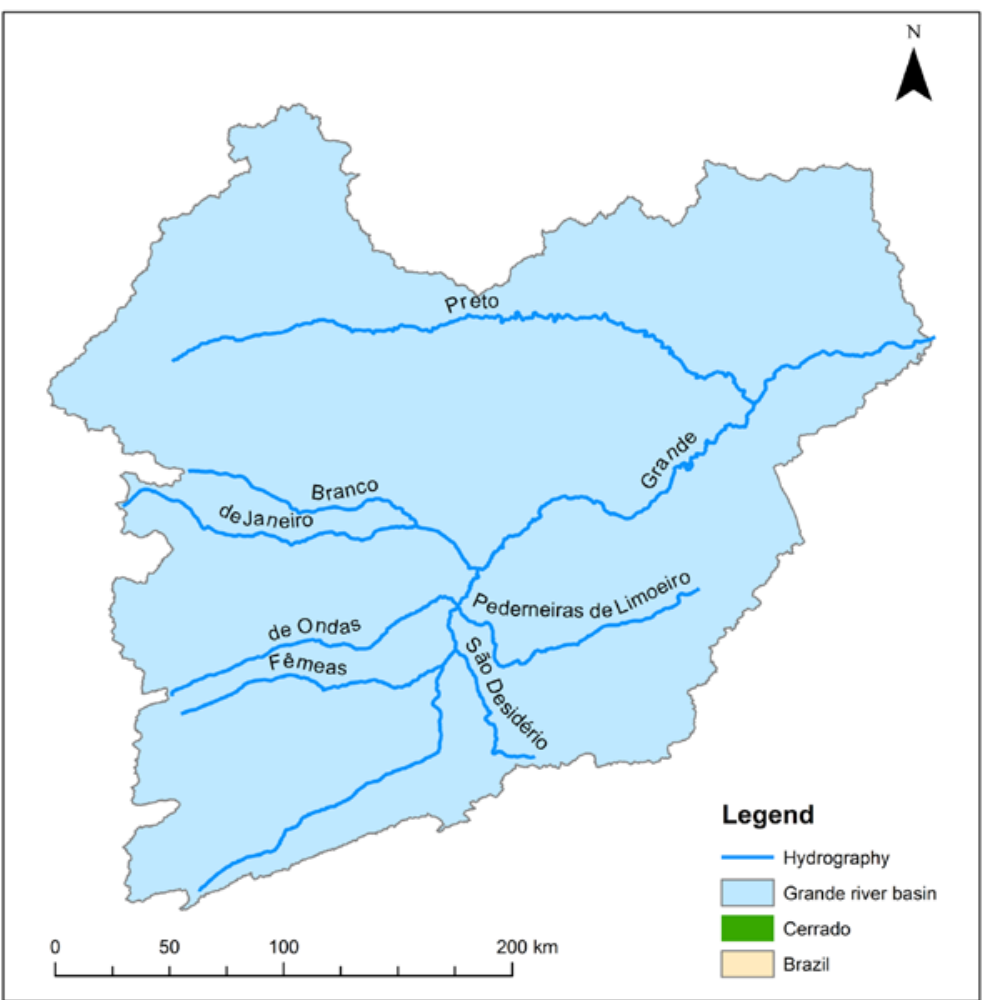

Figure 1. Location of the Grande River Basin.

\subsection{Simulation of water use charges through different methods}

The simulation of water-use charges in the Grande River Basin was carried out through methods adopted by the Committee for the Integration of the Hydrographic Basin of theParaíba do Sul River (CEIVAP); the Committee of the Hydrographic Basins of the Piracicaba, Capivari and Jundiaí Rivers (PCJ); the São Francisco River Hydrographic Basin Committee (CBHSF) and the Doce River Hydrographic Basin Committee (CBH-DOCE). The parameters and Equations 1, 2, 3 and 4 used in the simulation of the charges were obtained by CEIVAP (2014); PCJ (2007; 2012); CBHSF (2008; 2010) and CBH-DOCE (2011).

$\mathrm{VT}_{\text {CEIVAP }}=\left(\mathrm{V}_{\mathrm{CAP}}+\mathrm{V}_{\mathrm{CONS}}+\mathrm{V}_{\mathrm{DBO}}\right) \cdot \mathrm{K}_{\text {management }}$

where the

$\mathrm{VT}_{\text {CEIVAP }}=$ total value of the annual payment for water use, in US\$ year ${ }^{-1}$;

$\mathrm{V}_{\text {CAP }}=$ value of the annual payment for water catchment, in US\$ year ${ }^{-1}$;

$\mathrm{V}_{\text {cons }}=$ value of the annual payment for water consumption, in US\$ year ${ }^{-1}$;

$\mathrm{V}_{\text {DBO }}=$ value of the annual payment for organic load release, in US\$ year ${ }^{-1}$; and

$\mathrm{K}_{\text {management }}=$ coefficient of management, dimensionless.

$\mathrm{VT}_{\mathrm{PCJ}}=\left(\mathrm{V}_{\mathrm{CAP}}+\mathrm{V}_{\mathrm{CONS}}+\mathrm{V}_{\mathrm{DBO}}+\mathrm{V}_{\mathrm{SHP}}+\mathrm{V}_{\text {rural }}+\mathrm{V}_{\text {transp }}\right) \cdot \mathrm{K}_{\text {management }}$

where the

$\mathrm{VT}_{\mathrm{PCJ}}=$ total value of the annual payment for water use, in US\$ year ${ }^{-1}$;

$\mathrm{V}_{\mathrm{CAP}}=$ value of the annual payment for water catchment, in US\$ year $^{-1}$; 
$\mathrm{V}_{\text {cons }}=$ value of the annual payment for water consumption, in US\$ year ${ }^{-1}$;

$\mathrm{V}_{\mathrm{DBO}}=$ value of the annual payment for organic load release, in US\$ year ${ }^{-1}$;

$\mathrm{V}_{\mathrm{SHP}}=$ value of the annual payment for water use for hydroelectric generation in a Small Hydroelectric Plant (SHP), in US\$ year ${ }^{-1}$;

$\mathrm{V}_{\text {rural }}=$ value of the annual payment for water catchment and consumption for users of the rural sector, in US\$ year ${ }^{-1}$;

$\mathrm{V}_{\text {transp }}=$ value of the annual payment for water transposition, in US\$ year ${ }^{-1}$; and

$\mathrm{K}_{\text {management }}=$ coefficient of management, dimensionless.

$\mathrm{VT}_{\mathrm{CBHSF}}=\left(\mathrm{V}_{\mathrm{CAP}}+\mathrm{V}_{\mathrm{CONS}}+\mathrm{V}_{\mathrm{DBO}}\right) \cdot \mathrm{K}_{\mathrm{management}}$

where the

$\mathrm{VT}_{\mathrm{CBHSF}}=$ total value of the annual payment for water use, in US\$ year $^{-1}$;

$\mathrm{V}_{\mathrm{CAP}}=$ value of the annual payment for water catchment, in US\$ year ${ }^{-1}$;

$\mathrm{V}_{\text {cons }}=$ value of the annual payment for water consumption, in US\$ year ${ }^{-1}$;

$\mathrm{V}_{\mathrm{DBO}}=$ value of the annual payment for organic load release, in US\$ year ${ }^{-1}$; and

$\mathrm{K}_{\text {management }}=$ coefficient of management, dimensionless .

$\mathrm{VT}_{\mathrm{CBH}-\mathrm{Doce}}=\left(\mathrm{V}_{\mathrm{CAP}}+\mathrm{V}_{\text {disp }}+\mathrm{V}_{\text {transp }}+\mathrm{V}_{\mathrm{SHP}}\right) \cdot \mathrm{K}_{\text {management }}$

where the

$\mathrm{VT}_{\mathrm{CBH}-\mathrm{Doce}}=$ total value of the annual payment for water use, in US\$ year ${ }^{-1}$;

$\mathrm{V}_{\mathrm{CAP}}=$ value of the annual payment for water catchment, in US\$ year ${ }^{-1}$;

$\mathrm{V}_{\text {laun }}=$ value of the annual payment for organic load release, in US\$ year $^{-1}$;

$\mathrm{V}_{\text {transp }}=$ value of the annual payment for water transposition, in US\$ year ${ }^{-1}$;

$\mathrm{V}_{\mathrm{SHP}}=$ value of the annual payment for water use for hydroelectric generation in a Small Hydroelectric Plant (SHP), in US\$ year ${ }^{-1}$; and

$\mathrm{K}_{\text {management }}=$ coefficient of management, dimensionless.

\subsection{Analysis of the relative cost of charging on the production costs of water users}

In order to analyze the relative cost of charging for water on the production costs of water users, considering simulated charging methods, it was necessary to determine the total cost of production, in US\$ per year ${ }^{-1}$, for each one of the Grande River Basin’s user segments.

For irrigation, an average of the production costs for the three major crops in the region (maize, cotton and soy) was carried out, in US\$ per ha" ${ }^{-1}$ per year ${ }^{-1}$, with the costs based on data provided by CONAB (2015).

\section{IPABH}

Rev. Ambient. Água vol. 13 n. 5, e2238 - Taubaté 2018 
For animal consumption, costs were obtained from the Development Agency of the State of Bahia (DESENBAHIA, 2010), which were updated up to 2015 through livestock indicators from the Centre for Advanced Studies in Applied Economics (CEPEA) (CEPEA, 2016).

In relation to human supply and sanitation, costs were calculated based on the tariffs for commercial derivations of raw water of the Bahia Water and Sanitation Company (EMBASA). The determination of the total annual cost considered the flow granted and the annual consumption of the segment.

For the industrial supply, the following were taken into account: costs of production (US\$ per year $^{-1}$ ) obtained in the state of Santa Catarina (2012); the produced amount ( $\mathrm{t}$ per year ${ }^{-1}$ ), found in Bunge (2012); and the water demand for the food industry, obtained from CNI (2013).

In relation to sand mining in the river stream bed, production costs (US\$ per $\mathrm{t}^{-1}$ ) were obtained in DNPM (2015); the water demand for the extraction of sand came from MMA (Brasil, 2011). The relative cost was analyzed using the value of the charges through different methods and the costs of production for each segment, using Equation 5:

$\mathrm{RC}=\frac{\mathrm{TV}}{\mathrm{PC}}$

where the

$$
\begin{aligned}
& \mathrm{RC}=\text { relative cost of payment for water use, in \%; } \\
& \mathrm{TV}=\text { total value of charges for water use, in US\$ year }{ }^{-1} \text {; and } \\
& \mathrm{PC}=\text { production cost of the segment in analysis, US\$ year }{ }^{-1} \text {. }
\end{aligned}
$$

\section{RESULTS AND DISCUSSION}

\subsection{Grande River Basin Grants}

In the database of grants supplied by INEMA, there were 171 current grants in the Grande River Basin in September of 2015. Among those, 80 are intended for irrigation; 24 for animal watering; 20 for human supply; 16 for sanitation; 28 for industrial supply; two for sand mining; and one for a small hydroelectric plant (SHP). The total outflow granted in the Grande River Basin was $1,479,774,188.9 \mathrm{~m}^{3}$ per year-1 or $46.9 \mathrm{~m}^{3} \mathrm{~s}^{-1}$, as shown in Table 1 .

As per the analysis of figures presented in Table 1, irrigation has found to have a greater representativeness in terms of grants, comprising $46.4 \%$ of the flow rate granted in the Grande River Basin. The data confirm that the region is predominantly agricultural and the water is heavily used by this segment.

In addition, there were 332 processes considered insignificant uses in the database supplied by INEMA. The insignificant uses are exempted from the grant, but they total an outflow of $2,373,580.4 \mathrm{~m}^{3}$ per year-1 or $0,075 \mathrm{~m}^{3} \mathrm{~s}^{-1}$ in the Grande River Basin. The flow rate corresponding to the insignificant uses represents $0.2 \%$ of the flow grant in the basin, which is an insignificant value when compared to irrigated agriculture, but higher than the flow intended for animal watering, human supply and sand mining, as shown in Figure 2.

There is no consensus as to what is insignificant or little use. There is a tendency to abolish the insignificant term, since water uses do not fit into this category (ANA et al., 2004). The CEIVAP and CBH-Doce, in the Minas Gerais section of the basin, assume the derivations and catchments of up to $1 \mathrm{l} \mathrm{s}^{-1}$ or $86.4 \mathrm{~m}^{3}$ per day ${ }^{-1}$ as being of little significance (CEIVAP, 2014; $\mathrm{CBH}-D o c e, 2011)$. CBH-Doce, in the Espírito Santo stretch of the basin, considers $1.5 \mathrm{l} \mathrm{s}^{-1}$ or 
$129.6 \mathrm{~m}^{3}$ per day ${ }^{-1}$ as insignificant use (CBH-Doce, 2011), while CBHSF considers $4 \mathrm{l} \mathrm{s}^{-1}$ or 345, $6 \mathrm{~m}^{3}$ per day ${ }^{-1}$ in the main river channel and the PCJ adopts $5 \mathrm{~m}^{3}$ per day ${ }^{-1}$ as a low expression use (PCJ, 2007).

Correct identification of significant or insignificant uses becomes fundamental in the process of charging for water use because the uses that are considered insignificant are not charged. In accordance with ANA et al. (2004), the exemption of payment for water use derives from the stipulation of insignificant use as per Law No. 9,433 of 1997, stating that it must previously be proposed by the committee of the hydrographic basin for approval by the Board of Water Resources, after negotiations with users, the public authorities and the representatives of civil society.

Table 1. Water Use in the Grande River Basin.

\begin{tabular}{lcccc}
\hline Type of use & $\begin{array}{c}\text { Number of } \\
\text { grants }\end{array}$ & $\mathbf{\%}$ & $\begin{array}{c}\text { Outflow granted } \\
\left(\mathbf{m}^{\mathbf{3}} \text { year }^{-\mathbf{~}} \mathbf{)}\right.\end{array}$ & $\mathbf{\%}$ \\
\hline Irrigation & 80 & 46.8 & $687,233,628.9$ & 46.4 \\
Animal watering & 24 & 14.0 & $1,860,040.0$ & 0.1 \\
Human supply & 20 & 11.7 & $1,904,205.0$ & 0.1 \\
Sanitation & 16 & 9.4 & $404,720,395.0$ & 27.4 \\
Industrial supply & 28 & 16.4 & $5,569,170.0$ & 0.4 \\
Sand mining & 2 & 1.2 & $54,750.00$ & 0.01 \\
Small Hydroelectric Plant (SHP) & 1 & 0.6 & $378,432,000.00$ & 25.6 \\
\hline Total & $\mathbf{1 7 1}$ & $\mathbf{1 0 0}$ & $\mathbf{1 , 4 7 9 , 7 7 4 , 1 8 8 . 9 0}$ & $\mathbf{1 0 0}$ \\
\hline
\end{tabular}

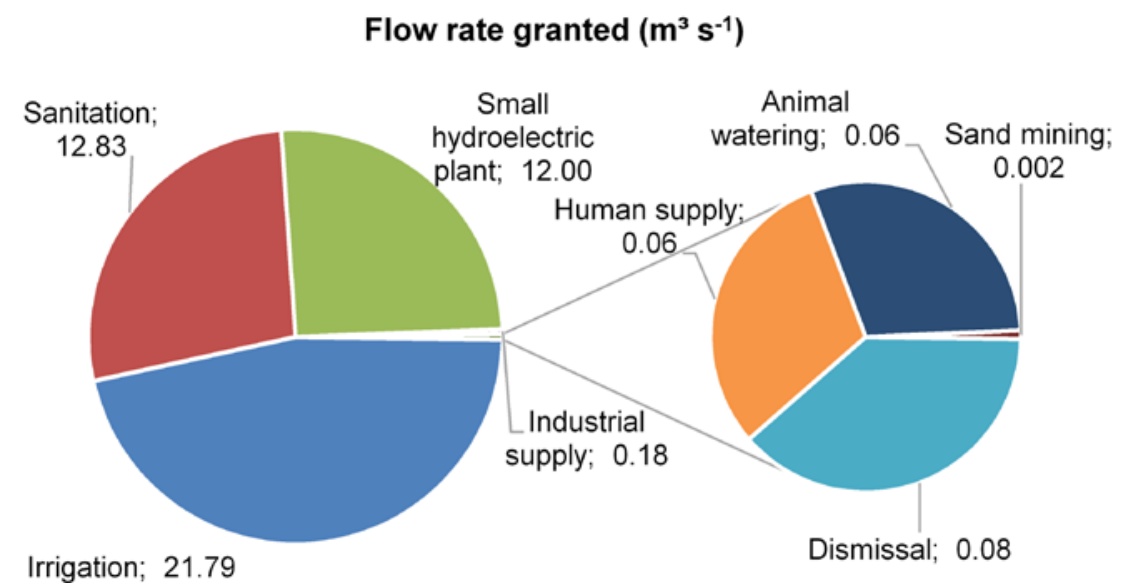

Figure 2. Dismissals of grant and other uses of water, in $\mathrm{m}^{3} \mathrm{~s}^{-1}$, in the Grande River Basin.

\subsection{Simulation for charging of water use using different methods}

The intensive use of irrigated agriculture characteristic of the region was demonstrated in the simulation of the CEIVAP's methods, representing $82.7 \%$ of the collection, followed by sanitation, at $8.7 \%$, and industrial supply, at $6.2 \%$. Other sectors were insignificant when considering the amount collected, since the representativeness did not exceed $2.1 \%$ of the simulated value, as shown in Table 2.

CEIVAP's method adopted progressive charging in its implementation in the Paraíba do Sul River Basin, but only for the agricultural and aquaculture sectors. According to this definition, the users included must pay $80 \%$ of the value charged in 2015 . By 2016, users should pay $90 \%$ of the amount charged, and in 2017 they must pay the total amount charged.

The estimated value of charging by PCJ's method exhibited a value close to the one simulated by CEIVAP's method, except for irrigation and sand mining. The difference for the 
irrigated agriculture was generated by the progressivity adopted by CEIVAP. For sand mining in the river stream bed, the discrepancy occurred because CEIVAP's method has specific parameters for this usage activity. The similarity between the simulations is linked to the similarity between the charging methods, which have public unitary prices (PUP) as a basic difference. The PUPs are values charged in US\$ $\mathrm{m}^{-3}$ for superficial catchment, consumption or waste discharges into water bodies.

The progressivity adopted by CEIVAP for the user segment of agriculture and aquaculture is an important strategy in encouraging an acceptance of the charges. The methodology followed allows the user to adapt to the charging process, paying a lower value initially, which is raised gradually until the full charge is reached.

The simulated charge values from CBHSF's methods and CBH-DOCE have proven to be different from CEIVAP's and PCJ's methods, but similar to each other. For the CBHSF's and CBH-DOCE's methods, the factor that justified the difference between these was the coefficient for irrigation, animal husbandry and aquaculture $(\mathrm{Kt})$, whose value of 0.025 substantially lowers the collection when these methods are applied. However, the simulated value was close to the other methods for human supply, sanitation (except CBH-DOCE), industrial supply and sand mining (except CEIVAP).

Table 2. Simulation of the charges for water use in the Grande River Basin considering different methods.

\begin{tabular}{|c|c|c|c|c|c|c|c|c|}
\hline $\begin{array}{l}\text { Type of } \\
\text { use }\end{array}$ & $\begin{array}{l}\text { CEIVAP } \\
\left.\text { (US\$ year-1) }^{-1}\right)\end{array}$ & $\%$ & $\begin{array}{c}\text { PCJ } \\
\left(\text { US\$ year-1) }^{-1}\right)\end{array}$ & $\%$ & $\begin{array}{c}\text { CBHSF } \\
\left(\text { US\$ year }^{-1}\right)\end{array}$ & $\%$ & $\begin{array}{l}\text { CBH-DOCE } \\
\text { (US\$ year-1) }^{-1}\end{array}$ & $\%$ \\
\hline Irrigation & $761,589.77$ & 82.7 & $1,027,842.12$ & 85.5 & $145,563.79$ & 48.9 & $177,911.30$ & 41.7 \\
\hline $\begin{array}{l}\text { Animal } \\
\text { watering }\end{array}$ & $1,526.88$ & 0.2 & $2,060.36$ & 0.2 & 452.34 & 0.2 & 481.53 & 0.1 \\
\hline $\begin{array}{l}\text { Human } \\
\text { supply }\end{array}$ & $19,539.19$ & 2.1 & $21,092.77$ & 1.8 & $18,523.40$ & 6.2 & $19,718.45$ & 4.6 \\
\hline Sanitation & $80,382.32$ & 8.7 & $89,064.07$ & 7.4 & $78,594.43$ & 26.4 & $169,876.90$ & 39.9 \\
\hline $\begin{array}{l}\text { Industrial } \\
\text { supply }\end{array}$ & $57,145.68$ & 6.2 & 61,689.37 & 5.1 & $54,174.81$ & 18.2 & $57,669.95$ & 13.5 \\
\hline $\begin{array}{l}\text { Sand } \\
\text { mining }\end{array}$ & 212.23 & 0.02 & 606.46 & 0.05 & 532.59 & 0.2 & 567.89 & 0.1 \\
\hline Total & 920,396.08 & 100 & $1,202,355.16$ & 100 & $297,841.36$ & 100 & $426,226.03$ & 100 \\
\hline
\end{tabular}

The grants for electricity production (Table 1) were not subject to the charging simulation due to the fact that it is regarded as a small hydroelectric plant (SHP) and, therefore, charging for water use is not allowed, as per Law No. 7,990/1989, along with Law No. 9,427/1996. As a result, according to ANA (2016), small hydropower plants (SHP) and hydroelectric generating stations (HGS) are not subject to paying for water use from the grants. In addition, the charges from SHP and HGS depend on regulation by competent federal authority (CEMIG, 2016; IGAM, 2011).

Thus, considering the estimated values for the simulations shown in Table 2, charges in the Grande River Basin, based on different charging methods, could allow investments of US\$1,202,355.16 (PCJ), US\$920,396.08 (CEIVAP), US\$426,226.03 (CBH-DOCE) or US\$297,841.36 (CBHSF) in this basin.

\subsection{Analysis of the relative cost of charges on production cost of water users}

For irrigated agriculture, the lowest relative cost on annual production costs was $0.19 \%$, simulated by the CBHSF's method; PCJ's method would cause a greater impact $(1.31 \%)$. The simulation using CEIVAP's method would provide a relative cost of $0.97 \%$, taking the 
progressivity of the farming method into account, as shown in Table 3.

The percentages ranged from $0.002 \%$ (CBHSF) to $0.011 \%$ (PCJ) for animal watering. CEIVAP's method led to an impact of $0.008 \%$, considering the progressivity, and $0.010 \%$, taking the entirety of the collection into account. The results showed that, for this user segment, the methods would cause a small increase in production costs when charging began to be enforced.

Charging methods caused a similar impact on water use for human supply. The percentages ranged from $0.26 \%$ (CBHSF) to $0.30 \%$ (PCJ), proving the adoption of any of the charging methods studied to be similar for this segment.

Table 3. Relative cost (RC) of charging for water use in the Grande River Basin considering different methods.

\begin{tabular}{lccccc}
\hline & $\begin{array}{c}\text { CEIVAP } \\
\mathbf{( \% )}\end{array}$ & $\begin{array}{c}\text { PCJ } \\
\mathbf{( \% )}\end{array}$ & $\begin{array}{c}\text { CBHSF } \\
\mathbf{( \% )}\end{array}$ & $\begin{array}{c}\text { CBH-DOCE } \\
\mathbf{( \% )}\end{array}$ & $\begin{array}{c}\text { Production cost } \\
\text { (US\$ year }^{-1} \text { ) }\end{array}$ \\
\hline RC Irrigation & 0.97 & 1.31 & 0.19 & 0.23 & $78,307,499.12$ \\
RC Animal watering & 0.008 & 0.011 & 0.002 & 0.003 & $18,240,605.20$ \\
RC Human supply & 0.28 & 0.30 & 0.26 & 0.28 & $7,098,642.96$ \\
RC Sanitation & 0.18 & 0.20 & 0.18 & 0.29 & $57,608,270.24$ \\
RC Industrial supply & 0.08 & 0.08 & 0.07 & 0.08 & $73,563,327.54$ \\
RC Sand mining & 0.23 & 0.66 & 0.58 & 0.62 & $92,058.62$ \\
\hline
\end{tabular}

The relative cost for sanitation ranged from 0.18\% (CEIVAP/CBHSF) to $0.29 \%$ (CBHDOCE). The highest percentage for the CBH-DOCE was caused by the public unitary prices for catchment and effluent release, which are higher than the other methods. Even so, the impact generated by the CBH-DOCE is insignificant, so it does not substantially affect the user segment.

For industrial supply, regardless of the charging method adopted, the impact generated would be basically the same, around $0.08 \%$. The variation is minimal, fluctuating from $0.07 \%$ to $0.08 \%$, resulting in a difference of $0.01 \%$ percentage point. For this segment, the choice of any method would maintain similar levels of collection.

The simulation for the riverbed sand mining sector demonstrated a similar impact in the different methods that were studied. Only the result of CEIVAP's method is different from the others, due to the fact that it carries a different equation to calculate charging for this segment. In addition, the impact generated by the CEIVAP does not exceed the $0.5 \%$ of production costs limit set by the method.

According to DAE (São Paulo, 2004), it can be asserted that international experiences have shown that the objective of obtaining financial resources prevails over environmental objectives, except in the Netherlands ${ }^{1}$, where the charging instrument has been effective both in revenue generation and pollution control, due to the high cost for the final user.

${ }^{1}$ The Basic Unit Price (PUB) varies from US\$ 30.00 to US\$ 60.00, depending on the region. 
The relative cost of charging for water use on users' production costs, considering the different charging methods, is low for most users and, consequently, ends up not fulfilling one of its purposes - which is to stimulate efficient water use (ANA, 2011). In order to set a maximum limit for charges in the Grande River Basin, which is under the responsibility of the River Basin Committee, the socioeconomic and environmental characteristics of the Western region of Bahia must be taken into account.

The Basin Committee must promote discussion of the issues of the impact of charging, minor uses, priorities for implementing charges and other issues related to water resources, considering the situation of the basin. These discussions will serve as a basis to set and approve the plan of the basin's water resources, which is of the utmost importance in implementing the charging and promotion of investments, geared towards improving the quality of the water and general environmental conditions of the hydrographic basin.

In the Grande River Basin, agriculture is highly technological and business-oriented, and is considered the largest consumer of water resources from the basin. With a maximum impact of $0.5 \%$ in production costs, as simulated by the CEIVAP, few users will be concerned about water use efficiency just because they are being charged. The farmer might be concerned because of the unavailability of water, i.e., when the grant is not sufficient to irrigate the entire area of interest, but not necessarily due to charging, since water charges would mean an average cost of 9.70 US\$ per ha ${ }^{-1}$ per year ${ }^{-1}$, as shown in Table 4.

Table 4. Charging cost for water use for irrigation in the Grande River Basin.

\begin{tabular}{lc}
\hline Method & Charging value (US\$ ha $\mathbf{~}^{\mathbf{1}}$ year $^{-1}$ ) \\
\hline CEIVAP & 13.98 \\
PCJ & 18.87 \\
CBHSF & 2.67 \\
CBH-DOCE & 3.27 \\
\hline Average & $\mathbf{9 . 7 0}$ \\
\hline
\end{tabular}

Using CEIVAP's method as an example, and considering the reduction of the relative cost of $0.97 \%$ presented in Table 3 for $0.5 \%$, the charging cost would fall from 13.98 US\$ per ha ${ }^{-1}$ per year ${ }^{-1}$, as in Table 4, to 7.18 US\$ per ha-1 per year ${ }^{-1}$. Thus, it can be verified that the setting of a low impact limit for agriculture will not stimulate more rational use, nor will it meet the objectives of charging for water use.

In Israel, for example, farmers are charged according to their water use, and prices range from 0.18 US\$ per $\mathrm{m}^{-3}$ to 0.29 US\$ per $\mathrm{m}^{-3}$, despite strong agricultural pressure for price increases. Charging is still not used as a primary source in Israel to induce the rational use of water (Cornish et al., 2004). The Brazilian levels are far below that, but to evaluate whether charging encourages conscious consumption at current values, the analysis should consider marginal costs and benefits provided by the charging, which is not the purpose of this study.

All existing charging methods in Brazil opt to charge considering the volume of water that was collected and/or the volume of released effluent, i.e., through volumetric methods. The same is true in relation to the granting of the right to water resources by the various regulatory agencies. In Bahia, for example, the ordinances of authorization or concession for water catchment are published with the flow granted in $\mathrm{m}^{3}$ per day ${ }^{-1}$, including the purpose of use and location of the land.

Cornish et al. (2004) state that the volumetric methods may not be of interest for developing countries due to the difficulty in installing measurement devices for users on a large scale, along with the costs therein. The authors also highlight the fragility of the devices when 
it comes to fraud or accidental damage.

Despite this, Foster and Hope (2017) demonstrated in their studies in rural communities in Kenya that volumetric basis charging provides a higher volume of revenue than charging flat fees.

Considering the statement by Cornish et al. (2004), measuring the water catchment will be the main problem in the Grande River Basin, as in order to estimate consumption recognized coefficients in the literature may be adopted for various segments, notably irrigated agriculture.

CEIVAP's and PCJ's methods are similar and generate intermediate impact in comparison with other methods, mainly for agriculture. These methods generate relative costs of charging of less than $1 \%$ on the production costs of user activities, except for irrigation (but this may be adjusted), and provide a higher collection than CBHSF and CBH-DOCE, which may allow larger investments for the improvement of the basin.

Because of the significant differences in the circumstances found between the Grande River and the PBS Basins, mainly in regard to irrigated agriculture, one of the possible adjustments to CEIVAP's method could involve not setting a limit for the impact on the agricultural sector. If this limit is set, it must not be insignificant; otherwise, it will not encourage rational water use.

In the Grande River Basin, pressures on water resources arising from the intensive use of water for irrigation and hydroelectric development projects for small hydroelectric plants (SHP) generate conflicts over water use. In a study performed by Almeida et al. (2014), they could identify segments of the Branco and Fêmeas Rivers, tributaries of the Grande River, with flows granted above legal limits established in the State of Bahia.

This context of dispute and water scarcity, at some points in the basin, is an incentive for instituting a water usage charge. With the implementation of this instrument by NWRP, in addition to encouraging rational use, charging would provide the acceptance of water as an economic good that is limited, encouraging users of water resources to request volumes closer to their real needs. Indeed, for Letsoalo et al. (2007), charging reduces the use of water, directly affecting the quantity of water consumed.

In this sense, Almeida and Curi (2016) propose a charging model with specific equations to discourage both granting requests above the users' needs and the use of water resources in a volume higher than that granted.

It is important to emphasize that the actions aimed to prevent water use conflicts must be carried out based on studies on the vulnerability of water resources (Almeida et al. 2014). These studies will support the process of granting and, consequently, the establishment of charging, the application of which must be consolidated through legal instruments.

Thus, considering the aspects discussed in this section, the CEIVAP or PCJ methods would be the most suitable ones in the context of the Grande River Basin, since the methods' parameters are in line with existing activities in the basin. Furthermore, these methods are closest to supplying economic and environmental prospects for charging, although adjustments are suggested.

However, it is important to emphasize that the introduction of charges for water use must be approved and established by the Grande River Basin Committee, which should institute the method and values to be charged.

\section{CONCLUSIONS}

Based on the analysis of the results, we can conclude that:

- Irrigation represents the usage with the largest number of grants and flow of water collected from the Grande River Basin.

\section{IPABH}

Rev. Ambient. Água vol. 13 n. 5, e2238 - Taubaté 2018 
- The simulations undertaken have confirmed the resources that could be raised and applied in the interventions for the water resources plan of the basin, providing a basis for discussions on the establishment of this instrument of water-resource management in the Grande River Basin.

- There is a possibility of implementing charges for water use in the Grande River Basin, with either the CEIVAP or PCJ method appearing to be the most suitable, given that the parameters of these mechanisms are in line with existing activities in the basin.

- Due to the significant differences between the Grande River- and PBS Basins, mainly with regard to irrigated agriculture, one of the possible adjustments to CEIVAP's method would involve not setting a limit for the economic impact on the agricultural sector. If this limit is set, it must not be insignificant; otherwise, it will not encourage rational water use.

\section{REFERENCES}

AGÊNCIA NACIONAL DE ÁGUAS - ANA (Brasil). Cobrança pelo uso de recursos hídricos. Brasília, 2016.

AGÊNCIA NACIONAL DE ÁGUAS - ANA (Brasil). Conjuntura dos recursos hídricos no Brasil. Brasília, 2013.

AGÊNCIA NACIONAL DE ÁGUAS - ANA (Brasil). Nota Informativa no. 03/2011/SAG. Brasília, 2011.

AGÊNCIA NACIONAL DE ÁGUAS - ANA (Brasil) et al. Plano decenal de recursos hídricos da bacia hidrográfica do rio São Francisco - PBHSF (2004-2013) - Resumo Executivo. Brasília, 2004.

ALMEIDA, M. A. de; CURI, W. F. Gestão do uso de água na bacia do Rio Paraíba, PB, Brasil com base em modelos de outorga e cobrança. Revista Ambiente \& Água, v. 11, n. 4, p. 989-1005, 2016. http://dx.doi.org/10.4136/ambi-agua.1820

ALMEIDA, W. A.; MOREIRA, M. C.; SILVA, D. D. Applying water vulnerability indexes for river segments. Water Resource Management, v. 28, p. 4289-4301, 2014. http://dx.doi.org/10.1007/s11269-014-0745-5

ARAÚJO, J. F.; DE CASTRO, A. P.; COSTA, M. M. C. et al. Microbial Ecology, v. 64, p. 760, 2012. https://doi.org/10.1007/s00248-012-0057-3

ASSOCIAÇÃO DE AGRICULTORES E IRRIGANTES DA BAHIA - AIBA. Anuário agropecuário do Oeste da Bahia: safra 2014/15. Barreiras: Ouza, 2015.

BRASIL. Departamento Nacional de Produção Mineral - DNPM. Sumário mineral 2014. Brasília, 2015.

BRASIL. Lei Federal n 9.433, de 8 de janeiro de 1997. Institui a Política Nacional de Recursos Hídricos, cria o Sistema Nacional de Gerenciamento de Recursos Hídricos, regulamenta o inciso XIX do art. 21 da Constituição Federal, e altera o art. $1^{\circ}$ da Lei $\mathrm{n}^{\circ}$ 8.001, de 13 de março de 1990, que modificou a Lei $n^{\circ}$ 7.990, de 28 de dezembro de 1989. Diário Oficial [da] União, 9 jan. 1997.

BRASIL. Ministério do Meio Ambiente. Desenvolvimento de matrizes de coeficientes técnicos para recursos hídricos no Brasil. Brasília-DF, 2011.

BUNGE. Relatório de sustentabilidade. São Paulo, 2012. 
CARVALHO, F. M. V.; MARCO JÚNIOR, P.; FERREIRA, L. G. The Cerrado into pieces: habitat fragmentation as a function of landscape use in the savannas of central Brazil. $\begin{array}{llllll}\text { Biological Conservation, } & \text { v. 142, po9. }\end{array}$ http://dx.doi.org/10.1016/j.biocon.2009.01.031

CENTRO DE ESTUDOS AVANÇADOS EM ECONOMIA APLICADA - CEPEA. Custos de produção da pecuária de corte. 2016. Available: http://cepea.esalq.usp.br/boi/?page=372. Access: 23 fev. 2016.

COMITÊ DA BACIA HIDROGRÁFICA DO RIO DOCE - CBH-DOCE. Deliberação CBHDOCE No. 26 de 31 de março de 2011. Governador Valadares, 2011.

COMITÊ DA BACIA HIDROGRÁFICA DO RIO SÃO FRANCISCO - CBHSF. Deliberação CBHSF no. 56/2010. Belo Horizonte, 2010.

COMITÊ DA BACIA HIDROGRÁFICA DO RIO SÃO FRANCISCO - CBHSF. Deliberação CBHSF No. 40/2008. Belo Horizonte, 2008.

COMITÊ DAS BACIAS HIDROGRÁFICAS DOS RIOS PIRACICABA, CAPIVARI E JUNDIAÍ - PCJ. Deliberação dos Comitês PCJ no. 160/2012. Piracicaba, 2012.

COMITÊ DAS BACIAS HIDROGRÁFICAS DOS RIOS PIRACICABA, CAPIVARI E JUNDIAÍ - PCJ. Deliberação Conjunta dos Comitês PCJ no. 78/2007. Piracicaba, 2007.

COMITÊ DE INTEGRAÇÃO DA BACIA HIDROGRÁFICA DO RIO PARAÍBA DO SUL CEIVAP. Deliberação CEIVAP no. 218/2014. Resende, 2014.

COMPANHIA NACIONAL DE ABASTECIMENTO - CONAB (Brasil). Custos de produção culturas de verão - Safra 2014-2015. Available: http://www.conab.gov.br/conteudos.php?a=1554\&t=2. Access: 2 Apr. 2015.

COMPANHIA DE ELETRICIDADE DO ESTADO DE MINAS GERAIS - CEMIG. Cobrança pelo uso da água. 2016. Available: https://goo.gl/jQVnS8. Access: 3 June 2016.

CONFEDERAÇÃO NACIONAL DA INDÚSTRIA - CNI. Uso da água no setor industrial Brasileiro: matriz de coeficientes técnicos. Brasília, 2013.

CONSELHO NACIONAL DO MEIO AMBIENTE - CONAMA (Brasil). Resolução n. 357. Diário Oficial [da] União, 18 mar. 2005.

CORNISH, G. et al. Water charging in irrigated agriculture: an analysis of international experience. Roma: FAO, 2004.

FEITOSA, G. D. S.; SANTOS, G. B. Identification of depositional landforms in environment of confluence of the Branco and Grande rivers, west region of Bahia State (Brazil): by trend surface. International Journal of river Basin Management, v. 14, n. 4, p. 407412, 2016. http://dx.doi.org/10.1080/15715124.2016.121532410.1080/15715124.2016.1215324

FOSTER, T.; HOPE, R. Evaluating waterpoint sustainability and access implications of revenue collection approaches in rural Kenya. Water Resources Research, v. 53, p. 1473-1490, 2017. http://dx.doi.org/10.1002/2016WR019634 
GARCÍA-VALIÑAS, M. A.; GONZÁLEZ-GÓMEZ, F.; PICAZO-TADEO, A. J. Is the price of water for residential use related to provider ownership? Empirical evidence from Spain. Utilities Policy, v. 24, p. 59-69, 2013. https://doi.org/10.1016/j.jup.2012.07.009

INSTITUTO DO MEIO AMBIENTE E RECURSOS HÍDRICOS - INEMA. CBH Grande: caracterização da bacia. 2014. Available: http://www.inema.ba.gov.br/gestao-2/comitesde-bacias/comites/cbh-grande. Access: 10 nov. 2014.

INSTITUTO MINEIRO DE GESTÃO DAS ÁGUAS - IGAM. Proposição de metodologia para implantação da cobrança pelo uso de recursos hídricos na bacia hidrográfica do rio Santo Antônio. Belo Horizonte, 2011.

JOHNSON, N.; WHITE, A.; PERROT-MAÎTRE, D. Developing markets for water services from forests: issues and lessons for innovators. Washington: Forest Trends; World Res. Institute; The Katoomba Group, 2002.

LETSOALO, A.; BLIGNAUT, J.; WET, T.; WIT, M.; HESS, S.; TOL, R. S. J. Triple dividends of water consumption charges in South Africa. Water Resources Research, v. 43, 2007. http://dx.doi.org/10.1029/2005WR004076

KLINK, C. A.; MACHADO, R. B. Conservation of the Brazilian Cerrado. Conservation Biology, v. 19, p. 707-713, 2005. http://dx.doi.org/10.1111/j.1523-1739.2005.00702.x

MOREIRA, M. C.; SILVA, D. D. Atlas hidrológico da bacia hidrográfica do Rio Grande. Barreiras: Gazeta Santa Cruz, 2010.

NAZER, D. W.; SIEBEL, M. A.; VAN DER ZAAG, P.; MIMI, Z.; GIJZEN, H. J. A financial, environmental and social evaluation of domestic water management options in the west bank, Palestine. Water Resource Management, v. 24, p. 4445-4467, 2010. http://dx.doi.org/10.1007/s11269-010-9667-z10.1007/s11269-010-9667-z

PASSO, D. P. et al. Caracterização geomorfológica do município de São Desidério, BA. Planaltina, DF: Embrapa Cerrados, 2010. Escala 1:50.000.

PEREIRA, S. B.; PRUSKI, F. F.; SILVA, D. D.; RAMOS, M. M. Estudo do comportamento hidrológico do rio São Francisco e seus principais afluentes. Revista Brasileira de Engenharia Agrícola e Ambiental, v. 11, n. 6, p. 615-622, 2007.

PLOEG, C. G. V.; SOMMERFELD, L. Charging for water use in Canada: a workbook of the central principles, key questions, and initial steps. Calgary: Canada West Foundation, 2011.

SANTA CATARINA. Diário Oficial [de] Santa Catarina, n. 19.336, de 21 de maio de 2012.

SÃO PAULO (Estado). Departamento de Águas e Energia Elétrica - DAE. Impacto da cobrança pelo uso da água por tipo de usuário, SRH. São Paulo, 2004.

SANTOS, G. B.; CASTRO, P. T. A. Sedimentological characteristics and geochemistry of lake waters of the Grande river basin, west of Bahia State (Brazil). International Journal of river Basin Management, v. 14, n. 4, p. 431-440, 2016. http://dx.doi.org/10.1080/15715124.2016.12153234:410.1080/15715124.2016.1215323 $4: 4$ 
SOUZA, R. C.; MENDES, I. C.; REIS-JUNIOR, F. B. et al. Shifts in taxonomic and functional microbial diversity with agriculture: How fragile is the Brazilian Cerrado? BMC Microbiology, v. 16, p. 42, 2016. http://dx.doi.org/10.1186/s12866-016-0657-z

VEIGA, L. B. E.; MAGRINI, A. The Brazilian Water Resources Management Policy: Fifteen Years of Success and Challenges. Fifteen Years of Success and Challenges. Water Resource Management, v. 27, p. 2287-2302, 2013. http://dx.doi.org/10.1007/s11269013-0288-110.1007/s11269-013-0288-1

WOLF, A. T.; KRAMER, A.; CARIUS, A.; DABELKO, G. Managing water conflict and cooperation. In: ASSADOURIAN, E. et al. State of the World: redefining global security, 2005. Washington: The WorldWatch Institute, 2005. 


Ambiente \& Água - An Interdisciplinary Journal of Applied Science
ISSN 1980-993X - doi:10.4136/1980-993X
www.ambi-agua.net
E-mail: ambi.agua@gmail.com

\title{
Elimination of chemical oxygen demand from domestic residual water by electrocoagulation with aluminum and iron electrodes
}

ARTICLES doi:10.4136/ambi-agua.2240

Received: 09 Feb. 2018; Accepted: 27 Aug. 2018

\section{Edwar Alejandro Aguilar Ascón}

\author{
Universidad de Lima, Lima, Peru \\ Instituto de Investigación Científica (IDIC). E-mail: eaguilaa@ulima.edu.pe
}

\begin{abstract}
This research determined the efficiency of removal of chemical oxygen demand (COD) by an electrocoagulation process. An electrocoagulation reactor with aluminum and iron electrodes was used to treat water from the treatment plant of the Research Center for Wastewater Treatment and Hazardous Waste. The COD removal percentage was a response variable for the experimental factorial design. The factors influencing the process were current intensity, treatment time, and $\mathrm{pH}$. The best results in the percentage of removal of the COD were very similar to that obtained at a $\mathrm{pH}$ of 8.2 and 7 , with values of $83 \%$ and $84 \%$, respectively, with a current intensity of $7 \mathrm{~A}$ and a treatment time of $15 \mathrm{~min}$. However, at $5 \mathrm{~A}$ and $10 \mathrm{~min}$, values that exceed $80 \%$ removal were obtained. Statistical analysis indicates that only current intensity and time were significant for the response variable. Electrocoagulation is a viable process for the treatment of this type of effluent, in addition to being more versatile compared with biological processes.
\end{abstract}

Keywords: aluminum electrode, COD, iron electrode, urban wastewaters.

\section{Eliminação da demanda química de oxigênio da água residual doméstica por eletrocoagulação com eletrodos de alumínio e ferro}

\section{RESUMO}

O objetivo desta pesquisa foi identificar a eficiência do processo de eletrocoagulação para a remoção da demanda química de oxigênio (DQO). Foi utilizada água da estação de tratamento do Centro de Pesquisas de Tratamento de Águas Residuais e Resíduos Perigosos, empregando um reator de eletrocoagulação cujos eletrodos são feitos de alumínio e ferro. O desenho experimental fatorial teve como variável de resposta a porcentagem de remoção da DQO e como fatores que influenciam o processo a intensidade da corrente, o tempo de tratamento e o $\mathrm{pH}$. Os melhores resultados relacionados à porcentagem de remoção da DQO foram muito semelhantes a um $\mathrm{pH}$ de 8,2 e 7 , com valores respectivos de $83 \%$ e $84 \%$, uma intensidade de corrente de 7 amperes e um tempo de tratamento de 15 minutos. Entretanto, utilizando uma intensidade de 5 amperes e um tempo de tratamento de 10 minutos, os valores obtidos superam $80 \%$ de remoção. A análise estatística indica que somente a intensidade da corrente e o tempo foram significativos para a variável de resposta. A eletrocoagulação é um processo viável para o tratamento deste tipo de efluentes, além de ser mais versátil do que os processos biológicos.

Palavras-chave: águas residuais urbanas, DQO, eletrodo de alumínio, eletrodo de ferro. 


\section{INTRODUCTION}

A large amount of wastewater is generated in Peru, mainly comprised of physiological waste from domestic and commercial human activity. According to the Agency of Environmental Evaluation and Control (OEFA), approximately 2,217,946 $\mathrm{m}^{3}$ of wastewater is generated per day in Peru, which is discharged into the public sewer system, wherein only $32 \%$ of the entire volume is treated. Only a fraction of the treated water is used to irrigate crops, green areas, or for fish farming.

These effluents are generally treated by biological processes (including activated sludge and stabilization ponds), which are based on the use of microorganisms for the degradation of organic matter and the removal of pollutants. The activated sludge is among the most efficient conventional processes, which achieves high percentages of chemical oxygen demand (COD) removal and biochemical oxygen demand (BOD). However, this technology is very sensitive to parameters such as organic load, $\mathrm{pH}$, dissolved oxygen, and presence of toxic compounds. In addition, supplying oxygen to biomass is required in this process, and its retention times are prolonged, which increases operational and maintenance costs.

Electrocoagulation is used to decontaminate various types of residual water; therefore, various studies have been conducted to better understand the mechanics of electrocoagulation. In 2013, Bazrafshan et al. (2013) investigated the effects of voltage, reaction time, and spacing between the plates during electrocoagulation in residual water that was obtained from the lactic industry using aluminum electrodes, which resulted in a COD elimination of $98.84 \%$ at $60 \mathrm{~V}$ for a period of $60 \mathrm{~min}$. In 2013, Al-Shannag et al. (2013) used the electrocoagulation technique with residual municipal water to improve the reduction of COD and obtained $86.0 \%$ and 89.10\% COD elimination without and with aeration, respectively. In the subsequent year, AlShannag et al. (2014) applied this process to reduce the COD of residual waters obtained from a bakery using iron electrodes, which evaluated the $\mathrm{pH}$ parameters and the density of the current, and obtained an elimination of up to 85\% COD with an energy consumption of $0.493 \mathrm{kWh}$. In 2017, Bani-Melhem et al. (2017) demonstrated the impact of the SCOD fraction with the total elimination of COD using $\mathrm{Al}$ and Fe electrodes to eliminate $96 \%$ of the total COD and $10 \%$ of the SCOD for 15 minutes of the electrocoagulation duration.

Additionally, in recent years, there have been efforts to improve the efficiency of elimination of COD and other containments using processes that combine electrocoagulation and chemical coagulation. In 2012, Bazrafshan (2012a; 2012b) applied this to the residual waters from a slaughterhouse and obtained an elimination of 99\% DBO by adding $100 \mathrm{mg}$ of chemical coagulants using aluminum electrodes and by applying 40 volts. In the same year, this process was applied to the residual waters from a car wash using polyaluminum chlorine and aluminum electrodes, which resulted in an elimination of 96.87\% of COD. In 2015, Bazrafshan et al. (2015) also applied this process to the residual water from the textile industry and reported a $98 \%$ elimination of COD.

There are a few specific studies that have applied electrocoagulation to either domestic or municipal residual water. In 2008, Ugur Kurt (Kurt et al., 2008) used an electrolysis cell to remove COD and suspended solids and obtained efficiencies of $60 \%$ and $70 \%$, respectively. In 2009, Fuat Ozyonar (Ozyonar and Karagozoglu, 2011) conducted tests in which they obtained $72 \%$ elimination of COD with aluminum electrodes at a natural $\mathrm{pH}$ of 7.8 and a treatment time of $10 \mathrm{~min}$.

The work by Sarala (2012) can also be cited, who evaluated the effect of iron electrodes in the removal of domestic wastewater, thereby obtaining a 90\% removal of COD in a contact time of $20 \mathrm{~min}$ and at a current intensity of 0.36 A. Further, in 2012, Moreno et al. (2013) treated the residual municipal waters to eliminate COD and obtained efficiencies of elimination that varied from $77 \%$ to $94 \%$ using iron electrodes. 
In another study in 2015, Nagarajappa used copper and aluminum electrodes at different time intervals, $\mathrm{pH}$, and voltage values to treat this type of effluent. Chemical demand for oxygen and nitrates were among the main parameters evaluated, with removal percentages of $63.2 \%$ and 62\%, respectively. Another study was completed by Lech Smoczyńskia in 2017, who used aluminum electrodes in residual municipal water and achieved COD elimination of up to $63.5 \%$. In recent years, the treatment of different types of wastewater using the electrocoagulation process has attracted considerable attention, increasing the amount of literature published on the subject (Kuokkanen et al., 2013).

In general, the electrocoagulation process is used to treat wastewater originating from industries. There are very few studies on the treatment of domestic wastewater; therefore, it is important to conduct studies with real effluents monitored on site and taking into account that the wastewater features may vary according to the country. This will allow us to obtain data to evaluate the feasibility of this process instead of the biological processes.

Considering the above-mentioned issue and to find alternatives for the treatment of domestic wastewater, the main objectives of this study were to determine the efficiency of the electrocoagulation process in the removal of COD and to study the impact of the main operational parameters on the alternative process. The results will allow us to verify what is indicated by the references on this process, which is a more versatile technology and less sensitive to the parameters that affect conventional water treatment processes.

Electrocoagulation is a complex process wherein various chemical and physical phenomena are involved and consumable electrodes such as iron and aluminum are supplied with electric current to release ions to the wastewater flow (Mollah et al., 2004). An electrocoagulation reactor is an electrochemical cell in which a sacrificial aluminum or iron electrode as the anode is dissolved; this dissolved electrode doses the coagulating agent in contaminated water (Holt et al., 2005). These ions serve as destabilizing agents for the emulsion by neutralizing the strengths of repulsion that are maintained by the suspended particles in an aqueous medium, which causes the agglomeration of the colloidal particles. (Al-Qodah et al., 2018). (See Figure 1). These agglomerates with a neutral load will either float or fall depending on their density. For example, if aluminum is used in an anode, aluminum cations will be produced $\left(\mathrm{Al}^{+3}\right)$, and aluminum will act as a coagulant agent that can be used in traditional treatment systems for residual waters. This process exhibits several advantages with respect to another treatment process that includes reduction of the production of mud, which makes the operation easier, and does not include the addition of chemical products.

At the same time, electrolytic gases (typically hydrogen) are generated at the cathode (Holt et al., 2005). The electrocoagulation reactors can be of a batch-type or continuous system reactors (Mollah et al., 2004). These types of reactors depend on the volume and features of the pollutants present in wastewater to be treated. The batch-type reactor can only treat a certain volume in a treatment cycle (Restrepo et al., 2006).

According to the literature, there are factors that significantly influence the efficiency of the electrocoagulation process, including $\mathrm{pH}$, conductivity, current density, and time of electrolysis for batch processes and flow velocity for continuous processes (Restrepo et al., 2006). These parameters will be described in more detail later.

The most commonly used materials for electrodes are aluminum and iron. Herein, we present their reactions according to Chen (2004) and Piña et al. (2011).

At the anode:

$A l-3 e \rightarrow A l^{3+}$

In alkaline conditions:

$\mathrm{Al}^{+3}+3 \mathrm{OH} \rightarrow \mathrm{Al}(\mathrm{OH})_{3}$ 
In acidic conditions:

$\mathrm{Al}^{+3}+3 \mathrm{H}_{2} \mathrm{O} \rightarrow \mathrm{Al}(\mathrm{OH})_{3}+3 \mathrm{H}^{+}$

For iron anode:

$\mathrm{Fe}-2 e \rightarrow \mathrm{Fe}^{2+}$

In alkaline conditions:

$\mathrm{Fe}^{2+}+2 \mathrm{OH}^{-} \rightarrow \mathrm{Fe}(\mathrm{OH})_{2}$

In acidic conditions:

$4 \mathrm{Fe}^{2+}+\mathrm{O}_{2}+2 \mathrm{H}_{2} \mathrm{O} \rightarrow 4 \mathrm{Fe}^{3+}+4 \mathrm{OH}^{-}$

The electrolysis of water produces oxygen and hydrogen in the following way:

At the anode:

$2 \mathrm{H}_{2} \mathrm{O}-4 e \rightarrow \mathrm{O}_{2}+4 \mathrm{H}^{+}$

At the cathode it is:

$2 \mathrm{H}_{2} \mathrm{O}+2 e \rightarrow \mathrm{H}_{2}+2 \mathrm{OH}^{-}$

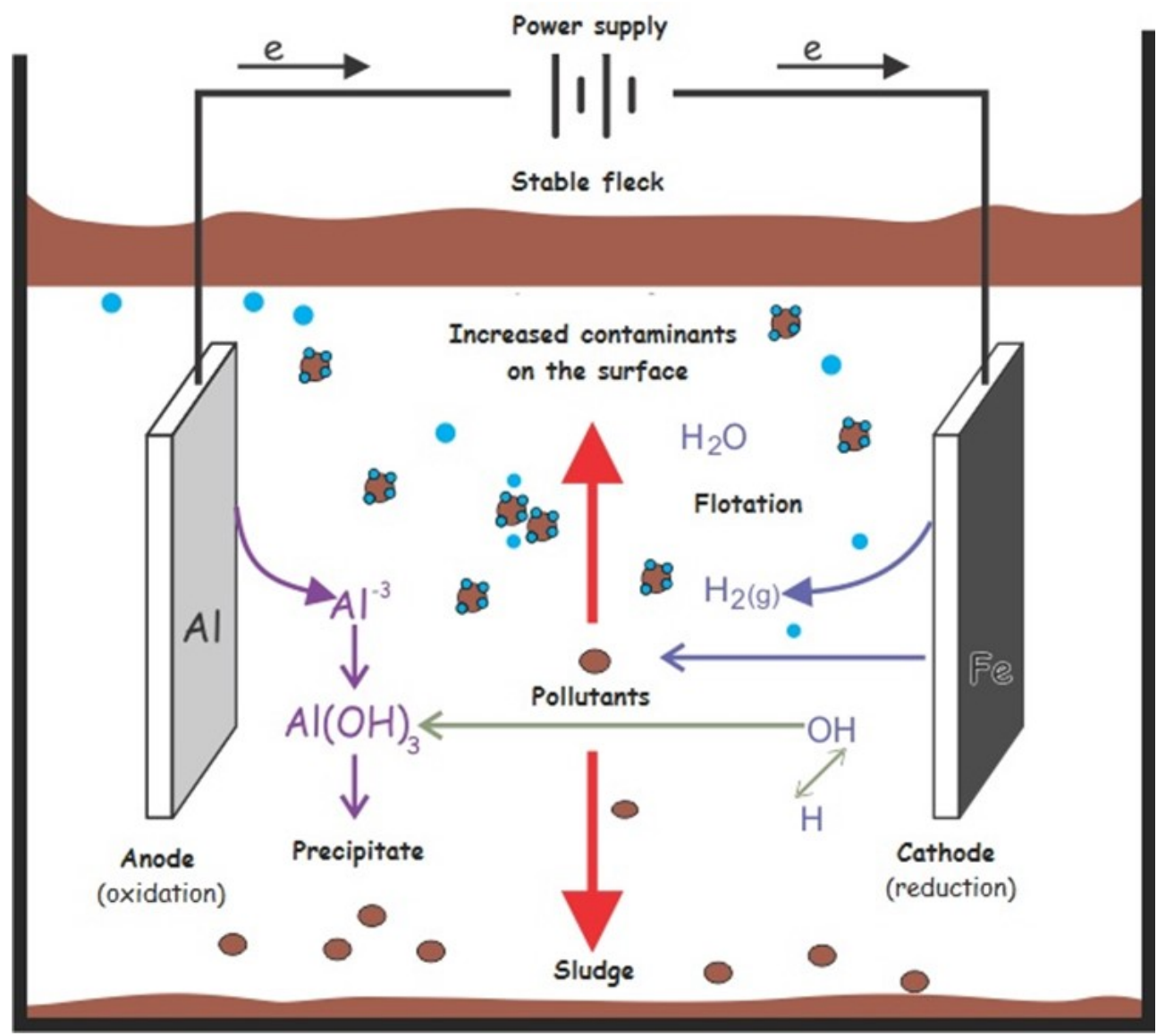

Figure 1. Interactions in the electrocoagulation process (Mollah, 2004).

The new ions of $\mathrm{Al}^{3+}$ or $\mathrm{Fe}^{2+}$ generated in the sacrificial electrodes are very efficient in the flocculation process, and they agglomerate colloidal particles. Hydrolyzed aluminum ions can form large networks of $\mathrm{Al}-\mathrm{O}-\mathrm{Al}-\mathrm{OH}$, which can remove various pollutants. Aluminum is generally used for the treatment of drinking water, and iron for wastewater treatment (Chen, 2004). 


\section{MATERIALS AND METHODS}

\subsection{Wastewater characterization}

For experimental tests, using actual wastewater taken on site was proposed because it presents totally different characteristics as compared with synthetic water used in the laboratory. The water was collected from the treatment plant located at the National College of Engineering's Research Center of Wastewater and Hazardous Waste, which has an outlet to a public network pipeline to be used in research. An initial characterization was performed to evaluate the features of this type of effluent; for the concluding tests, a considerable volume was collected in the early morning hours when there is a higher organic load.

\subsection{Electrocoagulation reactor}

The electrocoagulation reactor is designed to work in a batch type system with the capacity to treat $6.0 \mathrm{l}$ of domestic wastewater and has a footprint size of $15 \times 20 \times 22 \mathrm{~cm}$, with a free space for the accumulation of sludge. The material used for the reactor was made of a transparent acrylic material and was completely removable, which helps in observing the reactions during the process and for a better cleaning after each treatment. The supports on the bases allowed spacing to be adjusted between the plates of the electrodes. Four aluminum electrodes were used at the anode and four iron electrodes at the cathode, which were $10 \mathrm{~cm}$ wide, $10 \mathrm{~cm}$ long, and $0.01 \mathrm{~cm}$ thick, with an area of $100 \mathrm{~cm}^{2}$. The power source had the capacity to supply from 0 to 12 A with an adjustable voltage from 0 to $32 \mathrm{~V}$. A plastic tap was installed at the lower part of the reactor to obtain the samples at regular time intervals (See Figure 2).

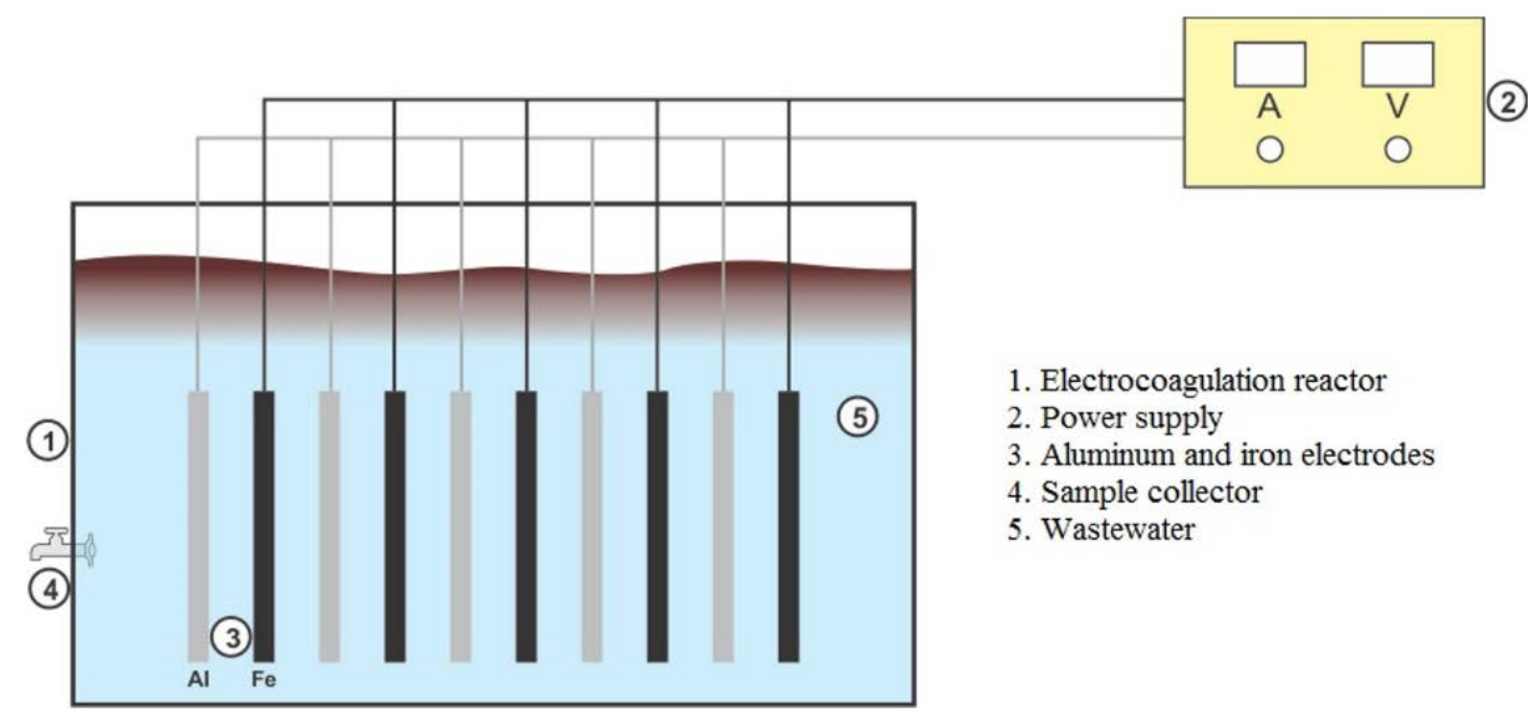

Figure 2. Diagram of the electrocoagulation reactor.

\subsection{Experimental tests}

Once the volume of water for the final tests had been taken, a sample was drawn to obtain the initial COD value of the wastewater to be treated. During the first stage, tests were conducted with an effluent at its natural $\mathrm{pH}$ of 8.2; the current intensities (3, 5, and $7 \mathrm{~A}$ ) were adjusted and samples were obtained at different times $(5,10$, and $15 \mathrm{~min}$ ) with each current intensity. During the second stage, the $\mathrm{pH}$ of its initial state was adjusted to 7 to verify how it influences the process. This is because several authors indicate that the best percentages of pollutant removal are obtained at $\mathrm{pH}$ values close to neutral. Conductivity, $\mathrm{pH}$, and temperature measurements were conducted on site with an OAKTON PCS 35 multi parameter, whereas the COD analyses were performed at the laboratory based on the SMEWW method APHA- 
AWWA-WEF 5220-D, 22nd Ed. 2012 COD Closed Reflux Method. Equation 1 was used to determine the COD removal percentage values.

$\% R=\frac{C O D i-C O D f}{C O D i} x 100$

Where:

$\%$ : COD removal percentage

$D Q O_{i}:$ Initial COD concentration $(\mathrm{mg} / \mathrm{L})$

$D Q O_{f}:$ Final COD concentration $(\mathrm{mg} / \mathrm{L})$

\subsection{Experimental design}

In this study, a factorial design with several levels was used. The efficiency of electrocoagulation is mostly influenced by the density of the current or voltage, the treatment time, the $\mathrm{pH}$ of the residual water, the conductivity, and the temperature (Piña et al., 2011; AlQodah and Al-Shannag, 2017); however, in case of a study related to the residual water that was obtained from a plant, not all these factors were considered due to the difficulty of handling them. Therefore, the factors that were considered in this design were the intensity of the current (A), time (B), and $\mathrm{pH}(\mathrm{C})$ along the variability of the results that were obtained in the percentage of elimination of COD (y).This allowed us to determine the individual effect and the interaction between the factors on the response variable and their significance in the process. All statistical analyses were performed using the Statgraphics Centurion XVI software. With these results, the analysis of variance (ANOVA) Table 1 with a confidence level of 95\%, regression coefficients of the second-order general polynomial equation, and the three-dimensional response surface graphs were obtained. Next, in Equation 2, we present the statistical model used for the analysis of the information:

$y_{i j k l}=\mu+\alpha_{i}+\beta_{j}+\gamma_{k}+(\alpha \beta)_{i j}+(\alpha \gamma)_{i k}+(\beta \gamma)_{j k}+\varepsilon_{i j k l}$

Where:

$y_{i j k l}: l-$ th observation of COD removal percentage.

$\mu:$ median COD removal percentage.

$\alpha_{i}, \beta_{j}, \gamma_{k}$ : effect of the current intensity factor, time and $p H$.

$(\alpha \beta)_{i j},(\alpha \gamma)_{i k},(\beta \gamma)_{j k}$ : effects of interaction of factors.

$\varepsilon_{i j k l}: l-$ th term of random error.

Table 1. Factors and levels in the experimental design.

\begin{tabular}{lcccc}
\multicolumn{1}{c}{ Factors } & \multicolumn{3}{c}{ Levels } \\
\hline A: Current intensity (A) & 3 & 5 & 7 \\
B: Time (min) & 5 & & 10 & 15 \\
C: pH & \multicolumn{2}{c}{7} & \multicolumn{2}{c}{8.2} \\
\hline
\end{tabular}




\section{RESULTS AND DISCUSSION}

The results of the initial characterization can be seen in Table 2, where it is observed that conductivity and $\mathrm{pH}$ have acceptable values to be used in the electrocoagulation process. In the definitive experimental tests, the initial value of the reported COD was $431 \mathrm{mg} / \mathrm{L}$ because the sample was obtained at the time of greatest organic load.

Table 2. Results of the chemical and biological physical analysis of the effluent.

\begin{tabular}{lc}
\hline Parameter & Value \\
\hline DQO (mg/L) & 347 \\
BOD $(\mathrm{mg} / \mathrm{L})$ & 182 \\
Conductivity ( $\mu \mathrm{S} / \mathrm{cm})$ & 847 \\
$\mathrm{pH}$ & 7.9 \\
Total solids (mg/L) & 74 \\
Oils and fats (UNT) & 19.2 \\
Total nitrogen (mg/L) & 39 \\
Total phosphorus (mg/L) & 4 \\
Total coliforms (NMP/100ml) & 4900000 \\
Fecal coliforms (NMP/100ml) & 2200000 \\
\hline
\end{tabular}

\subsection{Influence of retention time}

An increase in the retention time causes an increase in the consumption of energy, as well as in the consumption of the electrodes; that is why this parameter is important and must be considered since it is directly related to the economic applicability of the process (Kobya et al., 2006). Figures 3 and 4 show that after 10 min of treatment, the percentages of COD removal are similar and exceed $80 \%$, and there is no considerable variation until 15 min of treatment. Additionally, Karichappan, in 2014, indicated that the elimination efficiency of COD increases the time for electrolysis by up to $15 \mathrm{~min}$, after which the efficiency of elimination was observed to be almost constant. These results are very similar to those obtained by Bazrafshan et al. (2013), in which 75\% elimination of COD was observed 15 min into the treatment; further, an elimination of $98 \%$ was achieved 100 min into the treatment. During electrocoagulation, the concentration of the coagulant produced in the anode increased with time. Additionally, the amount of eliminated contaminant also increased with the time of electrolysis until an optimal time was reached. The optimal time is dependent on the density of the current and presents itself when the efficiency of the elimination of contaminants becomes constant.

\subsection{Influence of current intensity}

The current intensities used in the experimental part were 3, 5, and $7 \mathrm{~A}$, with a spacing of $10 \mathrm{~mm}$ between the electrodes, which was defined in previous studies and preliminary tests.

In Figures 4 and 6, it can be seen that at higher current intensity, the removal of COD is much faster after 5 min of treatment and then it becomes stable. This is similar to the findings by Merzouk et al. (2009), which indicate that the current intensity has a strong effect on the electrocoagulation process; particularly, in the kinetics of removal of pollutants, the higher the current, the shorter the treatment. This is because at high current intensity, the amount of anodic aluminum solution increases, which is favorable in view of allowing a greater amount of precipitate for the removal of pollutants. In contrast, an increase in the rate of bubble generation is observed, as well as the decrease in the size of the bubble, with the increase in intensity. All this is beneficial for the elimination of pollutants by flotation of $\mathrm{H}_{2}$ (Merzouk et al., 2009). This parameter directly determines the dose of the coagulant as well as the creation of gas bubbles. 
Therefore, it considerably influences the mixing of solutions and the transfer of mass to the electrodes (Al-Qodah end Al-Shannag, 2017). A very high value of current intensity can significantly decrease the efficiency due to the production of oxygen; moreover, it influences the passivation of the electrodes (Piña et al., 2011). It can be said that it is one of the factors that influence the electrocoagulation process the most and therefore the removal of pollutants from wastewater (Restrepo et al., 2006).

\subsection{Influence of $\mathbf{p H}$}

It is known that $\mathrm{pH}$ is an important parameter in the electrocoagulation process; optimal values thereof allow a better removal of pollutants. At a low $\mathrm{pH}$ between values of $2-3$, the cationic $\mathrm{Al}^{3+}$ and $\mathrm{Al}(\mathrm{OH})_{2}$ monomeric species predominate. When the $\mathrm{pH}$ is between 4 and 9, $\mathrm{Al}^{3+}$ and $\mathrm{OH}^{-}$ions generated by the electrodes react to form various monomeric species, such as $\mathrm{Al}(\mathrm{OH})^{2+}$ and $\mathrm{Al}(\mathrm{OH})^{22+}$, and polymeric species, such as $\mathrm{Al}_{6}(\mathrm{OH}){ }_{15}^{3+}, \mathrm{Al}_{7}(\mathrm{OH})_{17^{4+}}$, and $\mathrm{Al}_{13}(\mathrm{OH})_{34}{ }^{5+}$, that are eventually transformed into amorphous insoluble $\mathrm{Al}(\mathrm{OH})_{3(\mathrm{~s})}$ through polymerization and complex precipitation kinetics. When the $\mathrm{pH}$ is greater than 10 , the concentration of the monomeric anion of $\mathrm{Al}(\mathrm{OH})^{4-}$ increases at the expense of $\mathrm{Al}(\mathrm{OH})_{3(\mathrm{~s})}$. In addition, the cathode may be chemically attacked by $\mathrm{OH}^{-}$ions created with $\mathrm{H}_{2}$ to higher $\mathrm{pH}$ values (Merzouk et al., 2009). The nature and efficiency of the chemical reactions and complex electrochemical reactions are completely related to the $\mathrm{pH}$ of the system (Mansoorian et al., 2012).

In previous studies, it was found that the best turbidity and COD removals are obtained at $\mathrm{pH}$ values close to 7 (Restrepo et al., 2006). The effects of $\mathrm{pH}$ on water are reflected in the efficiency of the current and in the solubility of metal hydroxides (Piña et al., 2011). Keeping this in mind, the natural $\mathrm{pH}$ of the wastewater was modified to bring it to a value of 7 , and in this way, the effect of this parameter on the process was verified.

Figures 3 and 4 show the results obtained when treating water while maintaining the natural $\mathrm{pH}$ of the effluent, wherein the COD removal reached a value of $83 \%$ at a current intensity of 7 A.

The results obtained at $\mathrm{pH} 7$ can be seen in Figures 5 and 6, wherein the percentage of removal reached was $84 \%$, a value very close to that obtained at natural $\mathrm{pH}$, at an intensity of $7 \mathrm{~A}$ and a treatment time of $15 \mathrm{~min}$. These results do not match the value indicated by Piña and Restrepo, as a minimal improvement in the removal of pollutants at $\mathrm{pH}$ close to 7 was recorded. We can also highlight some coincidences with the study performed by Fuat Ozyonar (2011), in which he obtained the highest percentages of removal at a natural $\mathrm{pH}$ of 7.8 and $\mathrm{pH}$ close to neutral.

Along with these results, Al-Shannag et al. (2014) exhibited that these improved efficiencies that obtained a $\mathrm{pH}$ of 7 , or close to neutral, reported $81.7 \%$ of elimination of COD. This coincides with the observation of Bazrafshan et al. (2013), who indicated that the optimal results would obtain a $\mathrm{pH}$ of 7.24 . 


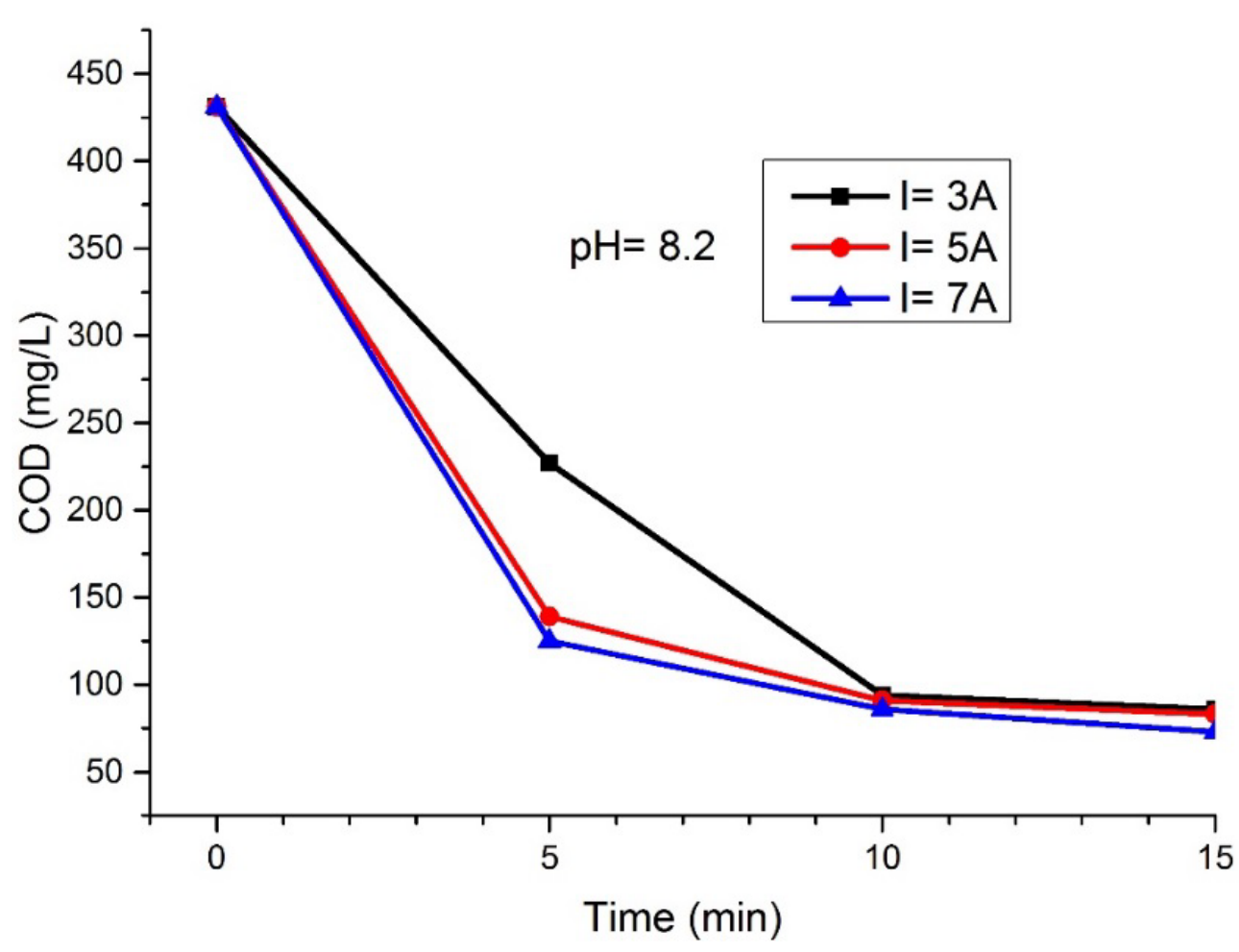

Figure 3. Variation of COD as a function of time at different current intensities $(\mathrm{COD} \mathrm{C0}=431 \mathrm{mg} / \mathrm{L}$ and $\mathrm{pH}=8.2)$.

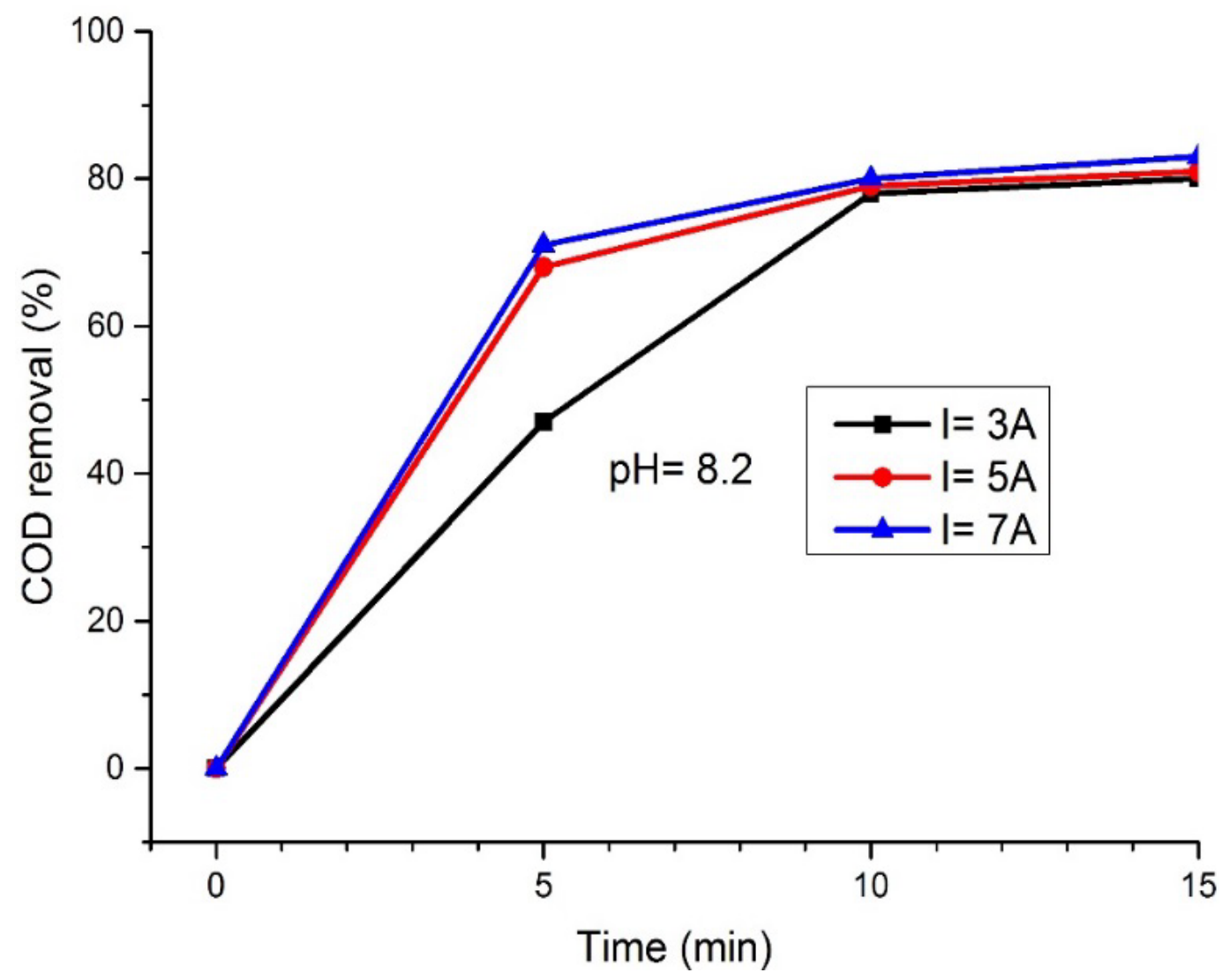

Figure 4. \% COD removal as a function of time (COD $\mathrm{C}_{0}=431 \mathrm{mg} / \mathrm{L}$ and $\mathrm{pH}=8.2$ ).

\section{IPABH}




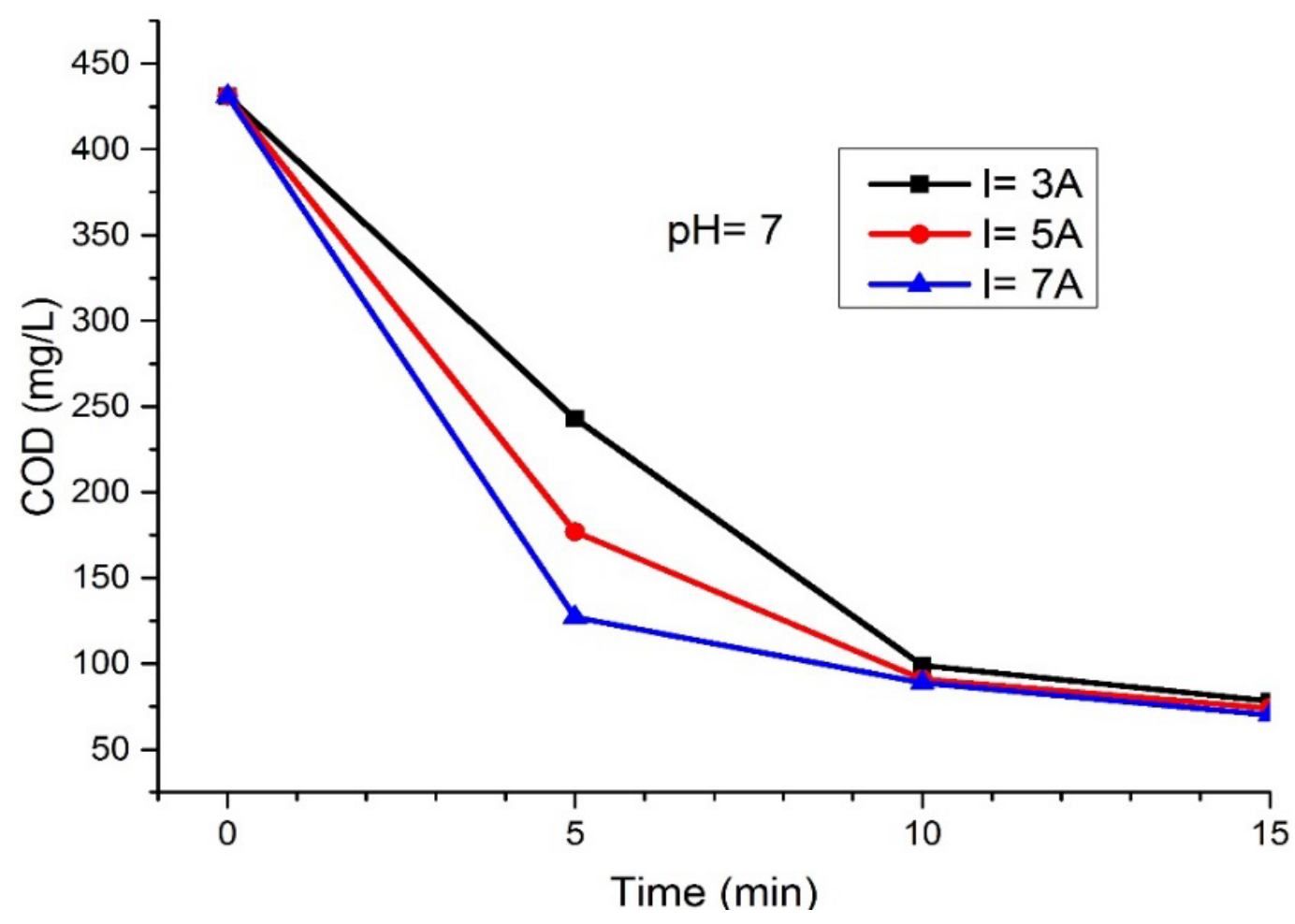

Figure 5. Variation of COD as a function of time at different current intensities (COD $\mathrm{C}_{0}=431 \mathrm{mg} / \mathrm{L}$ and $\mathrm{pH}=7$ ).

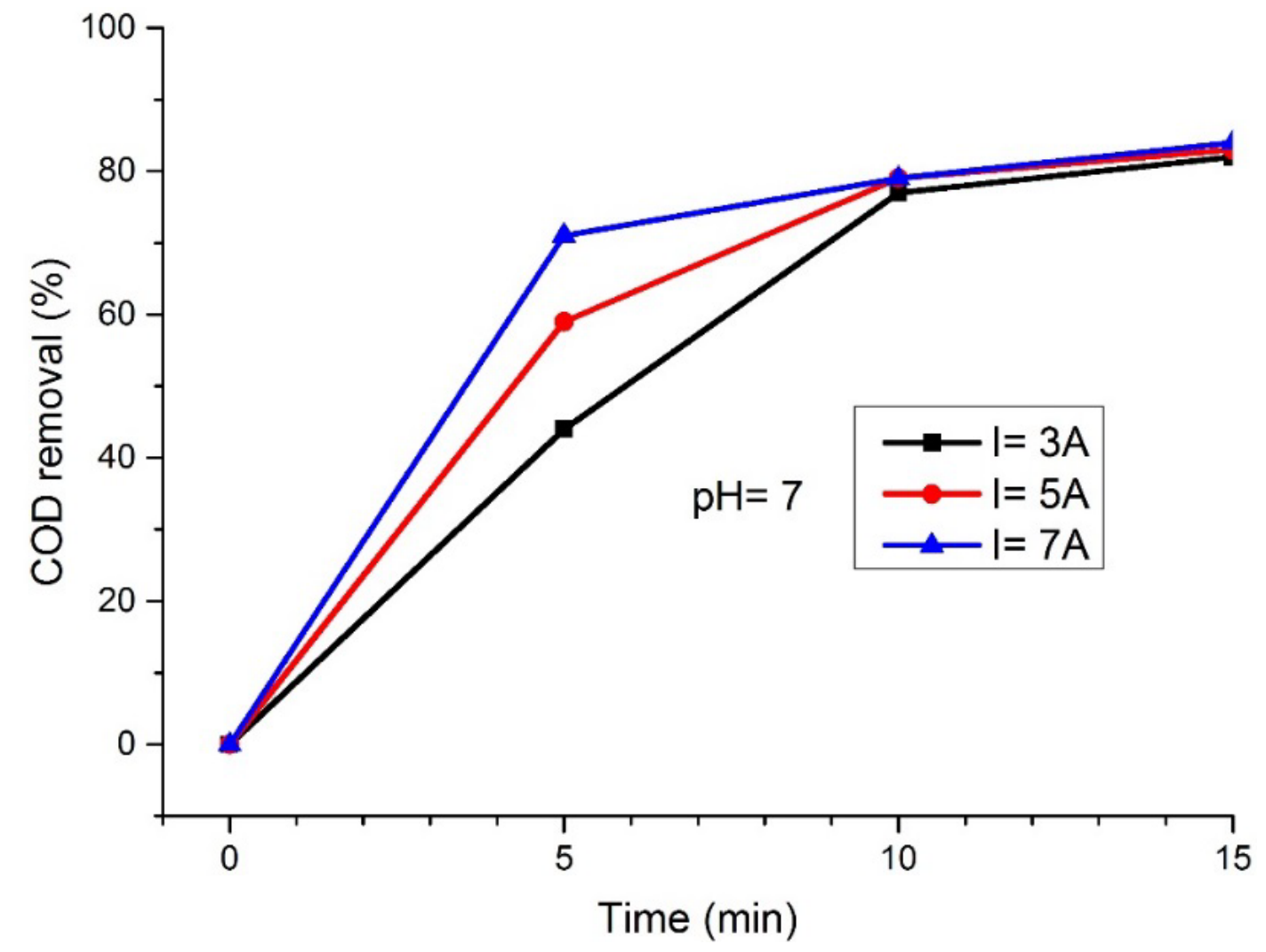

Figure 6. \% COD removal as a function of time $\left(\mathrm{COD} \mathrm{C}_{0}=431 \mathrm{mg} / \mathrm{L}\right.$ and $\left.\mathrm{pH}=7\right)$.

\subsection{Results of the experimental design}

The experimental design and the adjusted regression model that is used to quantitatively find the effects of these variables are shown in Table 3 and Equation 3. 
Table 3. Experiment design with the response variable for COD removal.

\begin{tabular}{ccccc}
\hline & \multicolumn{3}{c}{ Factors } & Removal (\%) \\
\cline { 2 - 5 } Exp. No. & Current Int. (A) & Time (min) & pH & COD \\
\cline { 2 - 5 } & A & B & C & Y \\
\hline 1 & 3 & 5 & 8.2 & 47 \\
2 & 3 & 10 & 8.2 & 78 \\
3 & 3 & 15 & 8.2 & 80 \\
4 & 3 & 5 & 7 & 44 \\
5 & 3 & 10 & 7 & 77 \\
6 & 3 & 15 & 7 & 82 \\
7 & 5 & 5 & 8.2 & 68 \\
8 & 5 & 10 & 8.2 & 79 \\
9 & 5 & 15 & 8.2 & 81 \\
10 & 5 & 5 & 7 & 59 \\
11 & 5 & 10 & 7 & 79 \\
12 & 5 & 15 & 7 & 83 \\
13 & 7 & 5 & 8.2 & 71 \\
14 & 7 & 10 & 8.2 & 80 \\
15 & 7 & 15 & 8.2 & 83 \\
16 & 7 & 5 & 7 & 71 \\
17 & 7 & 10 & 7 & 79 \\
18 & 7 & 15 & 7 & 84 \\
\hline
\end{tabular}

$Y(\%)=-72.8194+13.8889 A+14.7472 B+6.25 C-0.458333 A^{2}-0.575 A B-$

$0.138889 A C-0.303333 B^{2}-0.472222 B C$

Table 4 shows the ANOVA table, in which $\mathrm{r}^{2}$ correlation coefficient was found to be 0.9423 , which indicates that the proposed statistical model explains $94.23 \%$ of the variability of the COD removal ratio. This indicates a good fit of the model.

With respect to the significant effects of the variables, it can be determined that the effect of time and current intensity is significant at a level of $\alpha=0.05$, while $\mathrm{pH}$ was not significant on the response variable. Figures 7 and 8 show the Pareto diagram and the main effects on the response variable.

Table 4. ANOVA table for COD removal.

\begin{tabular}{lccccc}
\hline Source of variation & Sum of squares & GI & CM & F-ratio & P-value \\
\hline A: Current intensity (A) & 300 & 1 & 300 & 19.11 & 0.0018 \\
B: Time (min) & 1474.08 & 1 & 1474.08 & 93.89. & 0. \\
C: $\mathrm{pH}$ & 4.5 & 1 & 4.5 & 0.29 & 0.6054 \\
AA & 13.4444 & 1 & 13.4444 & 0.86 & 0.3789 \\
AB & 264.5 & 1 & 264.5 & 16.85 & 0.0027 \\
AC & 0.333333 & 1 & 0.333333 & 0.02 & 0.8874 \\
BB & 230.028 & 1 & 230.028 & 14.65 & 0.004 \\
BC & 24.0833 & 1 & 24.0833 & 1.53 & 0.2469 \\
Total error & 141.306 & 9 & 15.7006 & & \\
Total & 2452.28 & 17 & & & \\
\hline$r^{2}=94.23 \%$ & & & & &
\end{tabular}




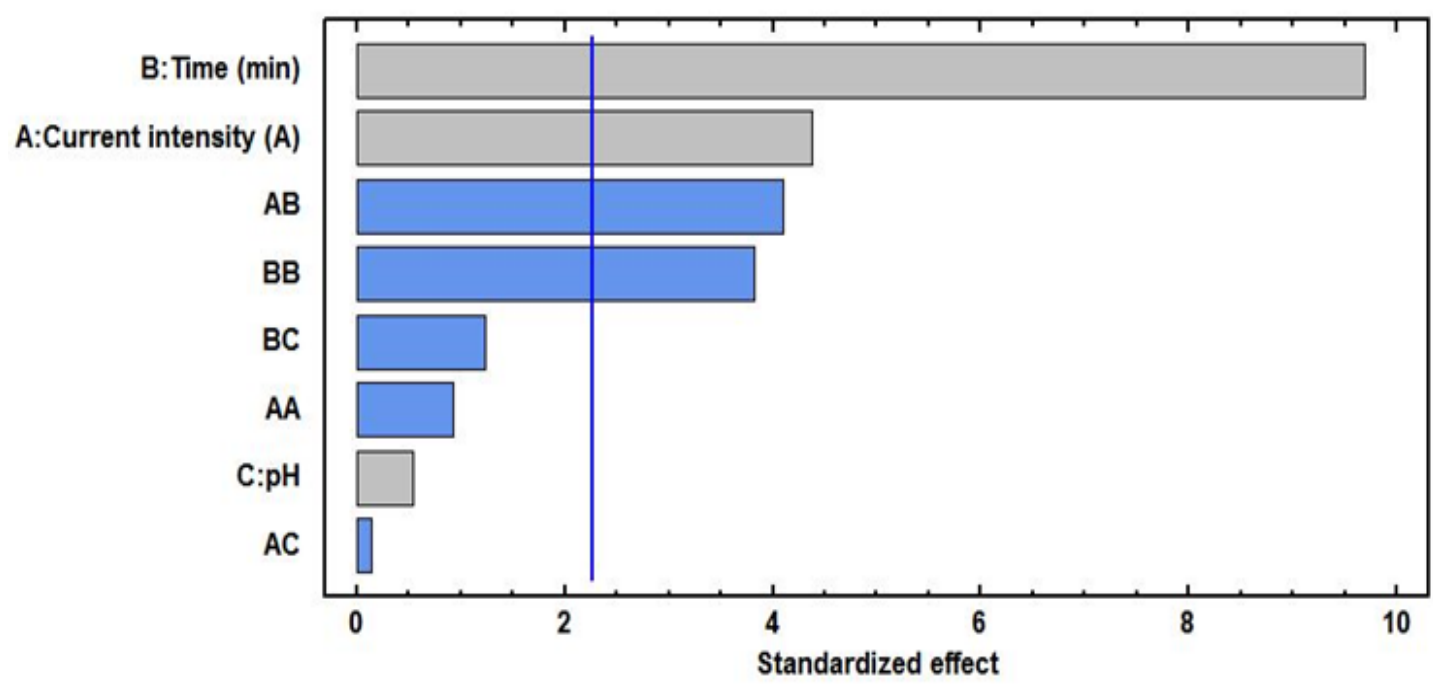

Figure 7. Standardized Pareto diagram for the removal of COD.

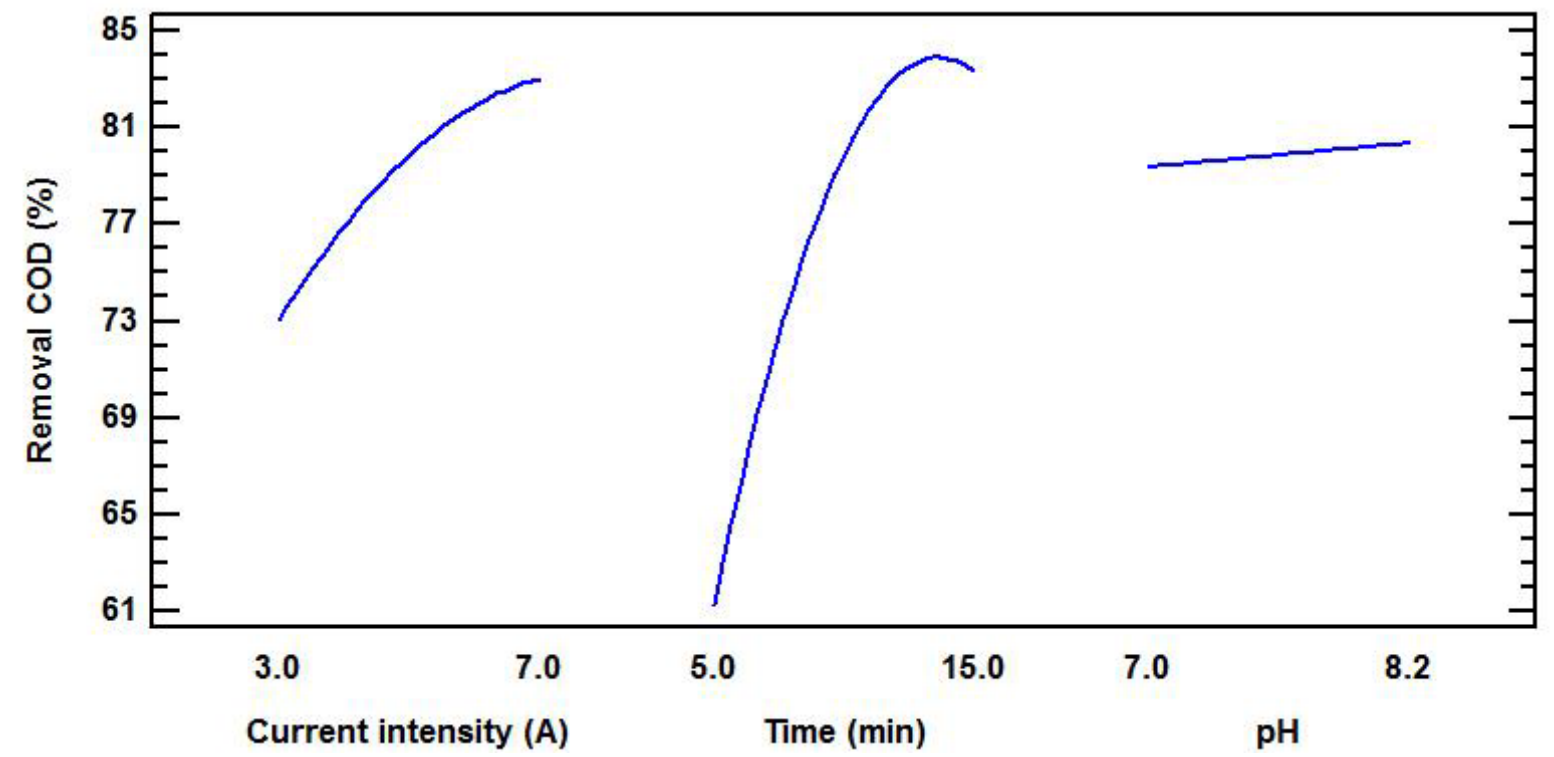

Figure 8. Graphical representation of the main effects for the removal of COD.

In addition, in Figures 9a, 9b, and 9c, the response surface graphs are presented that indicate the results of the variation of the percentage of COD removal as the current intensity, time, and $\mathrm{pH}$ conditions change, respectively. 


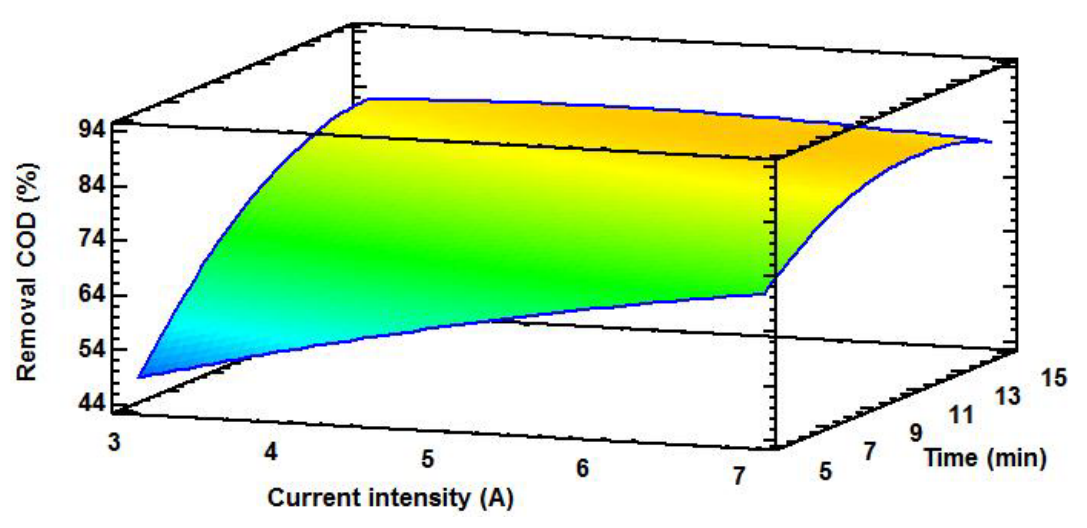

Removal COD (\%)

(9a)

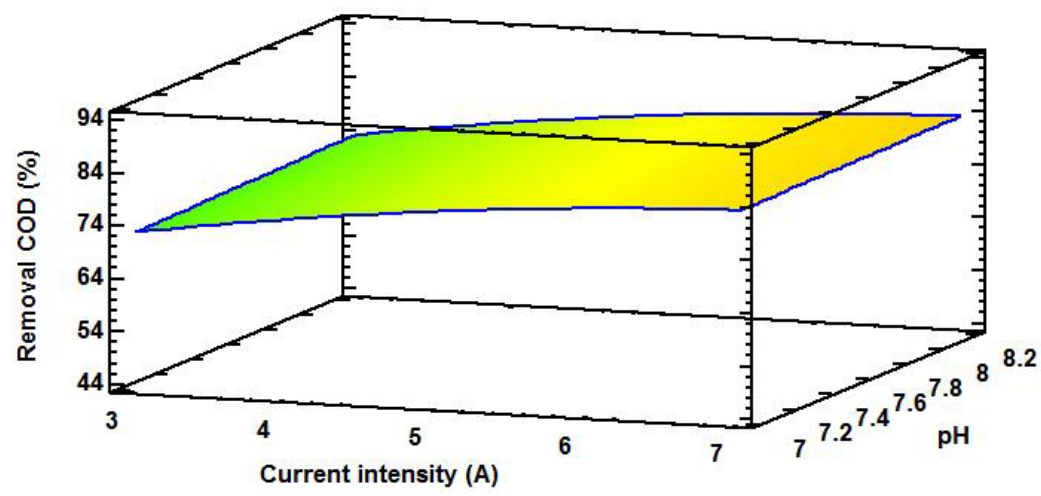

Removal COD (\%)

(9b)

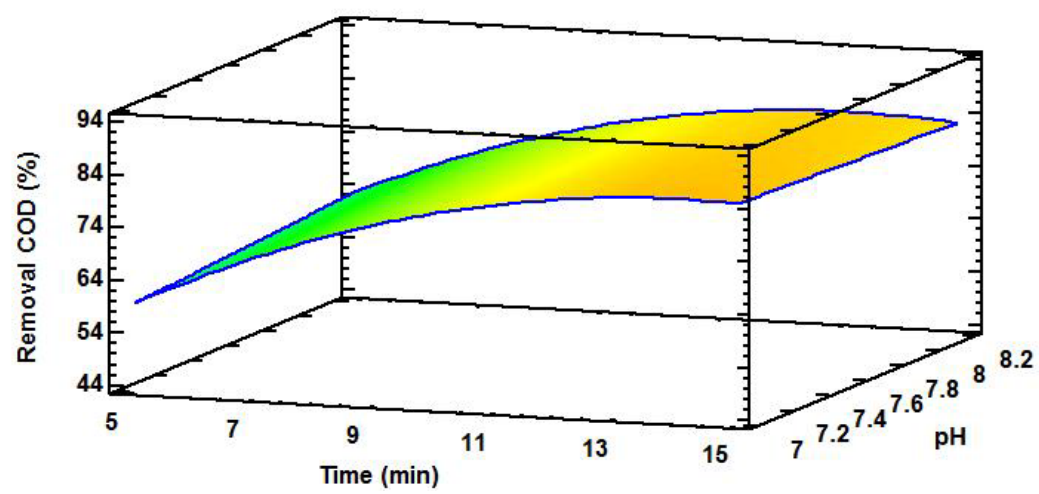

Removal COD (\%)

$\square 4.0$

$\square 49.0$

54.0

59.0

$\square 4.0$

$\square 69.0$

74.0

79.0

84.0
89.0

94.0

(9c)

Figure 9. Three-dimensional response surface graphs for the percentage of COD removal a) current and time intensity, b) current and $\mathrm{pH}$ intensity, and c) time and $\mathrm{pH}$.

\section{CONCLUSIONS}

Electrocoagulation is a viable alternative for the treatment of domestic wastewater, as it demonstrates its effectiveness in the removal of COD, and it is a more robust technology compared with biological processes. The analysis of the proposed experimental design indicates that the variable time and intensity of current were the most significant variables in the process, whereas the variable $\mathrm{pH}$ was not significant with respect to the response variable (percentage of COD removal) and had a correlation coefficient $r^{2}$ of $94.23 \%$. The best results in the percentage of removal of the COD were very similar as compared with the results at $\mathrm{pH} 7$ and 8.2 , with values of $84 \%$ and $83 \%$, respectively, with a current intensity of $7 \mathrm{~A}$ and a treatment 
time of 15 min.

Considering the treatment time, it was determined that the efficiencies obtained at $10 \mathrm{~min}$ were very similar with the three current intensities, with a minimal difference against those obtained at $15 \mathrm{~min}$. Considering the current intensity, the best removal results were obtained in the two types of $\mathrm{pH}$, at 5 and $7 \mathrm{~A}$; however, it is important to note that at an intensity of $3 \mathrm{~A}$, acceptable removal percentages were obtained that must be taken into account considering the treatment costs. The retention times being shorter than the biological processes and the compactness of the residual sludge are the other important aspects that were studied in this research. By considering the previous results, they can be considered as operational values, with a current intensity of $5 \mathrm{~A}$, a withholding time of $10 \mathrm{~min}$ and a natural $\mathrm{pH}$ of 8.2, with the goal of reducing the expense of energy and avoiding the use of reagents to lower the $\mathrm{pH}$. Another important aspect that should be noted is that the withholding times are considerably less than those observed in the biological process, which will allow us to eliminate the contaminants in short times. One of the advantages of this process is that it does not use bacteria to deteriorate the organic material, which ends up being easier to operate and maintain. Additionally, the residual mud that is generated is much more compact than biological and physiochemical mud.

\section{ACKNOWLEDGMENTS}

The authors would like to thank the Institute of Scientific Research from the University of Lima for promoting the integral development of this project and the Research Center for Wastewater Treatment and Hazardous Waste of the National University of Engineering for lending its facilities to conduct the field tests.

\section{REFERENCES}

AL-SHANNAG, M.; BANI-MELHEM, K.; AL-ANBER, Z.; AL-QODAH, Z. Enhancement of COD-Nutrients Removals and Filterability of Secondary Clarifier Municipal Wastewater Influent Using Electrocoagulation Technique. Separation Science and $\begin{array}{lllll}\text { Technology, } & \text { v. } & \text { 48,n. }\end{array}$ http://dx.doi.org/10.1080/01496395.2012.707729

AL-SHANNAG, M.; AL-QODAH, Z.; ALANANBEH, K.; BOUQELLAH, N.; ASSIREY, E.; BANI-MELHEM, K. Cod reduction of baker's yeast wastewater using batch electrocoagulation. Environmental Engineering \& Management Journal, v. 13, n. 12, p. 23153-3160, 2014.

AL-QODAH, Z.; AL-SHANNAG, M. Heavy metal ions removal from wastewater using electrocoagulation processes: a comprehensive review. Separation Science and $\begin{array}{lllll}\text { Technology, } & \text { v. } & 17, & \text { p. } & \end{array}$ http://dx.doi.org/10.1080/01496395.2017.1373677

AL-QODAH, Z.; AL-SHANNAG, M.; BANI-MELHEM, K. Free radical-assisted electrocoagulation processes for wastewater treatment. Environmental Chemistry Letters, 2018. http://dx.doi.org/10.1007/s10311-018-0711-1

BANI-MELHEM, K.; AL-SHANNAG, M.; ALROUSAN, D.; AL-KOFAHI, S.; ALQODAH, Z.; AL-KILANI, M. R. Impact of soluble COD on grey water treatment by electrocoagulation technique. Desalination and water treatment, v. 89, p. 101-110, 2017. http://dx.doi.org/10.5004/dwt.2017.21379 
BAZRAFSHAN, E.; KORD MOSTAFAPOUR, F.; FARZADKIA, M.; OWNAGH, K. A.; MAHVI, A. H. Slaughterhouse Wastewater Treatment by Combined Chemical Coagulation and Electrocoagulation Process. PLOS ONE, v. 7, p. 40108, 2012. http://dx.doi.org/10.1371/journal.pone.0040108

BAZRAFSHAN, E.; MOSTAFAPOUR, F. K.; SOORI, M. M.; MAHVI, A. H. Application of combined chemical coagulation and electrocoagulation process to carwash wastewater treatment. Fresenius Environmental Bulletin, v. 21, n. 9a, p. 2694-2701, 2012.

BAZRAFSHAN, E.; MOEIN, H.; KORD MOSTAFAPOUR, F.; NAKHAIE, S. Application of Electrocoagulation Process for Dairy Wastewater Treatment. Journal of Chemistry, v. 2013, p. 1-8, 2013. http://dx.doi.org/10.1155/2013/640139

BAZRAFSHAN, E.; ALIPOUR, M. R.; MAHVI, A. Textile wastewater treatment by application of combined chemical coagulation, electrocoagulation, and adsorption processes. Desalination and Water Treatment, v. 57, p. 9203-9215, 2015. http://dx.doi.org/10.1080/19443994.2015.1027960

CHEN, G. Electrochemical technologies in wastewater treatment. Separation and $\begin{array}{llllll}\text { Purification } & \text { Technology, } & \text { v. } & \text { 38, } & \text { p. } & \text { 11-41. }\end{array}$ http://dx.doi.org/10.1016/j.seppur.2003.10.006

HOLT, P.; BARTON, G.; MITCHELL, C. The future for electrocoagulation as a localized water treatment technology. Chemosphere, v. 59, p. 355-367, 2005. http://dx.doi.org/10.1016/j.chemosphere.2004.10.023

KARICHAPPAN, T.; VENKATACHALAM, S.; JEGANATHAN, P. M. Optimization of electrocoagulation process to treat grey wastewater in batch mode using response surface methodology. Journal of Environmental Health Science and Engineering, v. 12, p. 18, 2014. http://dx.doi.org/10.1186/2052-336X-12-29

KOBYA, M.; DEMIRBAS, E.; CAN, O.; BAYRAMOGLU, M. Treatment of levafix orange textile dye solution by electrocoagulation. Journal of Hazardous Materials, v. 132, p. 183-188, 2006. http://dx.doi.org/10.1016/j.jhazmat.2005.07.084

KUOKKANEN, V.; KUOKKANEN, T.; RAMO, J.; LASSI, U. Recent Applications of Electrocoagulation in Treatment of Water and Wastewater-A Review. Green and Sustainable Chemistry, v. 3, p. 89-121, 2013. http://dx.doi.org/10.4236/gsc.2013.32013

KURT, U.; GONULLU, M. T.; ILHAN, F.; VARINCA, K. Treatment of domestic wastewater by electrocoagulation in a cell with Fe-Fe electrodes. Environmental Engineering Science, v. 25, n. 2, p. 153-160, 2008. http://dx.doi.org/10.1089/ees.2006.0132

MANSOORIAN, H. J.; RAJABIZADEH, A.; BAZRAFSHAN, E.; MAHVI, A. H. Practical assessment of electrocoagulation process in removing nickel metal from aqueous solutions using iron-rod electrodes. Desalination and Water Treatment, v. 44, p. 2935, 2012. https://dx.doi.org/10.1080/19443994.2012.691708

MERZOUK, B.; GOURICH, B.; SEKKI, A.; MADANI, K. CHIBADNE, M. Removal turbidity and separation of heavy metals using electrocoagulation- electroflotation technique. A case study. Journal of hazardous materials, v. 164, p. 215-222, 2009. http://dx.doi.org/10.1016/j.jhazmat.2008.07.144 
MOLLAH, M.; MORKOVSKY, P.; GOMES, J.; KESMEZ, M.; PARGA, J.; COCKE, Fundamentals, present and future perspectives of electrocoagulation. Journal of Hazardous Materials, v. 114, p. 2004. https://dx.doi.org/10.1016/j.jhazmat.2004.08.009

MORENO, H.; PARGA, J.; GOMES, A.; RODRÍGUEZ, M. Electrocoagulation treatment of municipal wastewater in Torreon Mexico. Desalination and Water Treatment, v. 51, p. 2710-2717, 2013. https://dx.doi.org/10.1080/19443994.2012.749366

OZYONAR, F.; KARAGOZOGLU, B. Operating Cost Analysis and Treatment of Domestic Wastewater by Electrocoagulation using Aluminium Electrodes. Polish Journal of Environmental Studies, v. 20, p. 173-199, 2011.

PIÑA, M.; MARTÍN, A.; GONZÁLEZ, C.; PRIETO, F.; GUEVARA, A.; GARCÍA, Revisión de variables de diseño y condiciones de operación en la electrocoagulación. Revista Mexicana de Ingeniería Química, v. 10, n. 2, p. 257-271, 2011.

RESTREPO, A.; ARANGO, A.; GARCÉS, L. La Electrocoagulación: retos y oportunidades en el tratamiento de aguas. Producción + Limpia, v. 1, n. 2, p. 58-77. 2006.

SARALA, C. Domestic Wastewater Treatment by Electrocoagulation with Fe-Fe Electrodes. International Journal of Engineering Trends and Technology, v. 3, p. 530-533, 2012.

SMOCZYŃSKIA, L.; KALINOWSKIA, S.; RATNAWEERAB, H.; KOSOBUCKAA, M.; TRIFESCUA, M.; SMOCZYŃSKAA, K. P. Electrocoagulation of municipal wastewater - a pilot-scale test. Desalination and Water Treatment, v. 72, p. 162-168, 2017. http://dx.doi.org/10.5004/dwt.2017.20645 


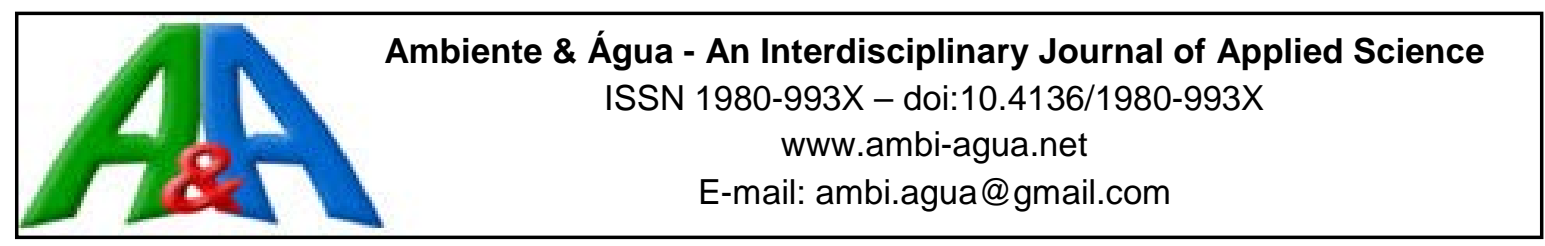

\title{
Integration of treatment technologies with Fenton reagent for laboratory effluent remediation
}

\author{
ARTICLES doi:10.4136/ambi-agua.2243
}

Received: 19 Feb. 2018; Accepted: 08 Jul. 2018

\author{
Chrystopher Allan Miranda Pereira; Núbia Natália Brito* \\ Universidade Federal de Goiás (UFG), Goiânia, GO, Brasil \\ Instituto de Química (IQ). E-mail: chrystophermiranda@gmail.com, nubiabrito@ufg.br \\ ${ }^{*}$ Corresponding author
}

\begin{abstract}
This study investigated of the potential value of the integration of the coagulation/flocculation, Advanced Oxidation Processes (AOP) (Fenton reagent) and slow sand filtration technologies, with the aim of treating laboratory wastewater. The treatment system was designed in laboratory scale through coagulation/flocculation. It involved the use of Jar Test equipment with a sequence of two rotational phases: fast mixes to $300 \mathrm{rpm}$ for 20 seconds and slow mixes to 30 rpm for 6 minutes and 10 seconds, with the addition of anionic polymer and sedimentation for 60 minutes at ambient temperature. In the treatment via Fenton reagent, two rotational phases were used: rapid mixing at $300 \mathrm{rpm}$ for 20 seconds with the addition of iron $\left(\mathrm{Fe}^{2+}\right)$ and slow mixing at 30 rpm for 6 minutes and 10 seconds with the addition of hydrogen peroxide, followed by 60 minutes of sedimentation at ambient temperature. A cylindrical tank of polyvinyl chloride, sands and non-woven synthetic fabrics were used in the slow filtration. The filtration rate adopted was $3 \mathrm{~m}^{3} \mathrm{~m}^{-2} \mathrm{~d}^{-1}$ with a hydraulic retention time of 264 minutes. The best concentrations of chemical reagents used in the treatments were: $0.80 \mathrm{mg} \mathrm{L}^{-1}$ of polymeric anionic, $200.00 \mathrm{mg} \mathrm{L}^{-1}$ of $\mathrm{H}_{2} \mathrm{O}_{2}$ and $13.00 \mathrm{mg} \mathrm{L}^{-1}$ of total soluble iron. The integration of the treatment technologies made it possible to achieve a removal rate of $75.27 \%$ of COD and $94.12 \%$ of total phenols. Furthermore, the conjugation of the processes allowed the removal of $87.58 \%$ of TOC.
\end{abstract}

Keywords: coagulation/flocculation, cosmetics, textile dyes.

\section{Integração de tecnologias de tratamento com reagente de Fenton para remediação de efluente laboratorial}

\section{RESUMO}

Neste trabalho a potencialidade da integração de tecnologias coagulação/floculação, processo oxidativo avançado (reação de Fenton) e filtração lenta foram estudados com o objetivo de tratar resíduo líquido laboratorial apresentando compostos da indústria cosmética e têxtil, principalmente. O sistema de tratamento foi realizado em escala laboratorial através da coagulação/floculação, o equipamento de jarros foi utilizado com uma sequência de duas fases de rotação: mistura rápida a 300 rpm por 20 segundos, mistura lenta a 30 rpm durante 6 minutos e 10 segundos com a adição de polímero aniônico e com um tempo de sedimentação de 60 minutos em temperatura ambiente. No tratamento via reagente de Fenton duas fases de rotação 
foram estudadas: mistura rápida a 300 rpm por 20 segundos com a adição de ferro $\left(\mathrm{Fe}^{2+}\right)$, mistura lenta a 30 rpm durante 6 minutos e 10 segundos com a adição de peróxido de hidrogênio e 60 minutos de sedimentação em temperatura ambiente. Na filtração lenta foi utilizado um tanque cilíndrico de policloreto de vinila, areia e mantas sintéticas não tecidas. A taxa de filtração adotada durantes os experimentos foi de $3 \mathrm{~m}^{3} \mathrm{~m}^{-2} \mathrm{~d}^{-1}$ com um tempo de detenção hidráulica de 264 minutos. As melhores concentrações de reagentes químicos utilizados nos tratamentos foram: 0,80 mg L${ }^{-1}$ de polímero aniônico, 200,00 $\mathrm{mg} \mathrm{L}^{-1}$ de $\mathrm{H}_{2} \mathrm{O}_{2}$ e 13,00 $\mathrm{mg} \mathrm{L}^{-1}$ de ferro solúvel total. A integração das tecnologias de tratamento permitiu a remoção de $75,27 \%$ de DQO e $94,12 \%$ de fenóis totais. Além disso, a conjugação dos processos permitiu remoção de COT de 87,58\%.

Palavras-chave: coagulação/floculação, cosméticos, corantes têxteis.

\section{INTRODUCTION}

The cosmetic industry in Brazil showed a rapid growth up to 2014, compared with other industrial sectors. However, in 2015 the sector showed a decline of about $9 \%$ for the first time in the last 20 years (ABIHPEC, 2017). The cosmetics are produced and used on a massive scale for aesthetic purposes and the huge amount of drinking water used in the refrigeration system, steam generation and particularly for the washing of machines, equipment and utensils, is a cause of concern in the cosmetics industry, since it results in a significant amount of effluent for waste disposal.

According to Banerjee and collaborators (2016), the effluents of the cosmetic industry are harmful from an environmental standpoint; they include high concentrations of organic compounds of slow biodegradability, as well as the presence of anionic surfactants, grease and oils. These impede the aeration of the medium and the transfer of soluble substrates to microorganisms that might have been able to accomplish the degradation of the organic matter and which will hence reduce the rate of the substrate conversion.

Another important industry in Brazil is the dye sector; dyes are widely used in several industrial areas, such as textiles, leather, paper, plastics, foods and rubber for the coloration of their products. Annually more than 10.000 tons of dyes are used, and approximately 100 tons are released into watercourses (Ashrafi et al., 2017).

Water contamination caused by the release of textile dyes can have a considerable impact on the ecosystem. Effluents from the textile industry are considered to be the worst pollutants of water bodies and soils. The dyes cause an undesirable color in the water when they are disposed of without treatment and lead to a reduction of solar radiation, which affects the photosynthetic activity of aquatic organisms (Semeraro et al., 2015).

In addition, the textile dyes are characterized as mutagen agents that are carcinogenic, allergic and cytotoxic and represent a risk to all forms of life (Khandare and Govindwar 2015). Some of them are not biodegradable and undergo biomagnification along the food chain.

The integration of the coagulation/flocculation, advanced oxidation (Fenton reagent) and slow filtration processes was studied in an attempt to remediate the effluents discharged by the laboratory and address the problem outlined above. The effluent mainly contained compounds from the cosmetics and textile industry

\section{MATERIALS AND METHODS}

\subsection{Site of experiments and effluent generation}

The experiments were carried out at the Wastewater Treatment Laboratory, located at the Chemistry Institute, Goiás Federal University, where the coagulation/flocculation, Fenton 
reagent and slow filtration were performed. The analysis to monitor the efficiency of the treatment was carried out in the Residual Wastewater Treatment Laboratory and the Laboratory of Analytical Instrumentation IQ-UFG.

The effluent used in this research was packaged in 50 liter bottles at room temperature and included the following: a liquid by-product of other treatments performed in the Laboratory of Wastewater Treatment, a liquid mixture with chemical compounds in sunscreen, hair conditioners, textile dyes, the analysis of liquid wastewater and environmental procedures carried out by the Wastewater Treatment Laboratory team.

\subsection{Experimental methodology}

In evaluating the rate of efficiency, we carried out analyses in duplicate such as: absorptivity performed at maximum absorption wavelength, turbidity, total residual soluble iron, residual hydrogen peroxide, chemical oxygen demand (COD), oil and greases, $\mathrm{pH}$, total organic carbon (TOC), total solids (TS), total fixed solids (TFS), total volatile solids (TVS) and settleable solids (SS). All the analyses (except residual hydrogen peroxide) complied with the Standard Methods for Examination of Water and Wastewater (SMEWW) 20th Edition (APHA, 1998).

The determination of residual hydrogen peroxide follows procedures adopted by Oliveira et al. (2001), and depend on the reaction between hydrogen peroxide and vanadate ion $\left(\mathrm{VO}_{3}^{-}\right)$ in acid medium. The reaction leads to the formation of peroxovanadium ion $\left(\mathrm{VO}_{2}^{3+}\right)$, which is of a reddish color and absorbs strongly at $446 \mathrm{~nm}$.

The coagulation/flocculation process and the Fenton reaction were performed with jar test equipment using a one-liter volume, and varying rotations between 30 and $300 \mathrm{rpm}$ with sedimentation for 60 minutes. The parameters of rotation and treatment time, as well as the range of initial concentrations of chemical reagents were used for two treatment technologies (coagulation/flocculation and Fenton's reagent) and based on the values of the parameters used in the wastewater treatment station-Goiânia-GO and in Morais and Brito (2015).

The studies of the treatment technology through coagulation/flocculation were initiated using a factorial experimental design $\left(2^{2}\right)$ that was built for experiments 2 levels: a smaller level $(-)$ and larger one $(+)$ for the variables: concentration of anionic polymer $(0.60$ and $1.40 \mathrm{mg} \mathrm{L}^{-1}$ ) and $\mathrm{pH}$ values (6.00 and 8.00); making a total of four experiments.

The treatment with Fenton's reagent to plan a factorial design for the studies was built at $2^{3}$ where there were 2 levels: a smaller level (-) and larger one $(+)$ for the variables: concentration of total soluble iron (2.33 and $\left.6.50 \mathrm{mg} \mathrm{L}^{-1}\right), \mathrm{pH}$ values (3.00 and 5.00) and concentration of peroxide of hydrogen (100.00 and $\left.200.00 \mathrm{mg} \mathrm{L}^{-1}\right)$; making a total of eight experiments.

The dosage of chemical reagents used for the coagulation/flocculation assays ranged from $0.00 \mathrm{mg} \mathrm{L}^{-1}$ to $2.00 \mathrm{mg} \mathrm{L}^{-1}$ of anionic polymer and the $\mathrm{pH}$ values varied from 3.00 to 10.00 . Fenton's reagent treatment concentration of chemical reagents ranged from $2.33 \mathrm{mg} \mathrm{L}^{-1}$ to $90.00 \mathrm{mg} \mathrm{L}^{-1}$ for a total soluble iron concentration, $100.00 \mathrm{mg} \mathrm{L}^{-1}$ to $1200.00 \mathrm{mg} \mathrm{L}^{-1}$ for hydrogen peroxide concentration and a variation in $\mathrm{pH}$ values from 3.00 to 5.50 .

Approximately $200.00 \mathrm{~mL}$ of supernatant liquid were collected from the two treatment systems after sedimentation; values of $\mathrm{pH}$, turbidity, chemical oxygen demand (COD), total residual soluble iron, absorbance and residual hydrogen peroxide (in the case of $\mathrm{H}_{2} \mathrm{O}_{2}$ residual, only in treatment via Fenton's reaction) were measured to determine the efficiency of the treatment through variations in the values of these parameters during the treatment operations.

The COD determination was performed after an increase of $\mathrm{pH}$ to 8.00 and the sample was then heated to $80^{\circ} \mathrm{C}$ for 40 minutes to remove residual $\mathrm{H}_{2} \mathrm{O}_{2}$. The sample remained at rest for 2 hours (ambient temperature) to sediment residual iron that interferes with the result (Cavalcante, 2005).

\section{IPABH}

Rev. Ambient. Água vol. 13 n. 5, e2243 - Taubaté 2018 
A cylindrical tank made of PVC (polyvinyl chloride) with a height of $55.00 \mathrm{~cm}$ and a diameter of $14.50 \mathrm{~cm}$ was used to construct a slow filter. The collection system, which also consisted of a PVC pipe, originated from the drainage system that follows the sand layer described above. Thus it was able to avoid the occurrence of negative pressure and, hence, the accumulation of air inside the filter medium, as well as ensuring the constant presence of effluent inside the filter. The adopted rate was $3 \mathrm{~m}^{3} \mathrm{~m}^{-2} \mathrm{~d}^{-1}$ and this was monitored periodically by the volumetric method of analysis.

The thickness of the filter material consisted of a $20 \mathrm{~cm}$ layer of fine sand used in civil engineering, followed by $5 \mathrm{~cm}$ of $\mathrm{n}^{0} 2$ crushed stone used as a support layer. The sand was washed with water and dried in the environment with solar radiation after being placed in a slow filter.

A non-woven synthetic blanket of brand GeotêxtilGeoFort GF Model 17 was placed between the crushed stone layer and the sand layer. Its features were as follows: $95.70 \%$ porosity, specific surface of $2.530 \mathrm{~m}^{2} \mathrm{~m}^{-3}$, weight $400 \mathrm{~g} \mathrm{~m}^{-2}$, thickness of $3 \mathrm{~mm}$ and $100 \%$ polypropylene composition to prevent sand from permeating the crushed stone. At the top of the sand layer, two non-woven synthetic blankets (Model 17) were used to prolong the effective time of the filter media and make the "schmutzdecke" development more efficient. The treatment began on June 13, 2016 at 1:00 p.m. and the treatment lasted for 264 minutes.

The slow filter was operated with a sample of effluent, batch processing system. The analyses were only employed for the monitoring of the treatment efficiency after some preliminary tests had been carried out. This was accomplished so that the filter could acquire a period of biological development and maturation.

The stages of the research treatment of the technologies tested are separated in the way shown in Figure 1 which represents the crude laboratory effluent involving a primary treatment through coagulation/flocculation, and subsequently a secondary treatment with Fenton's reagent and concluding with the slow filtration to provide final polishing.

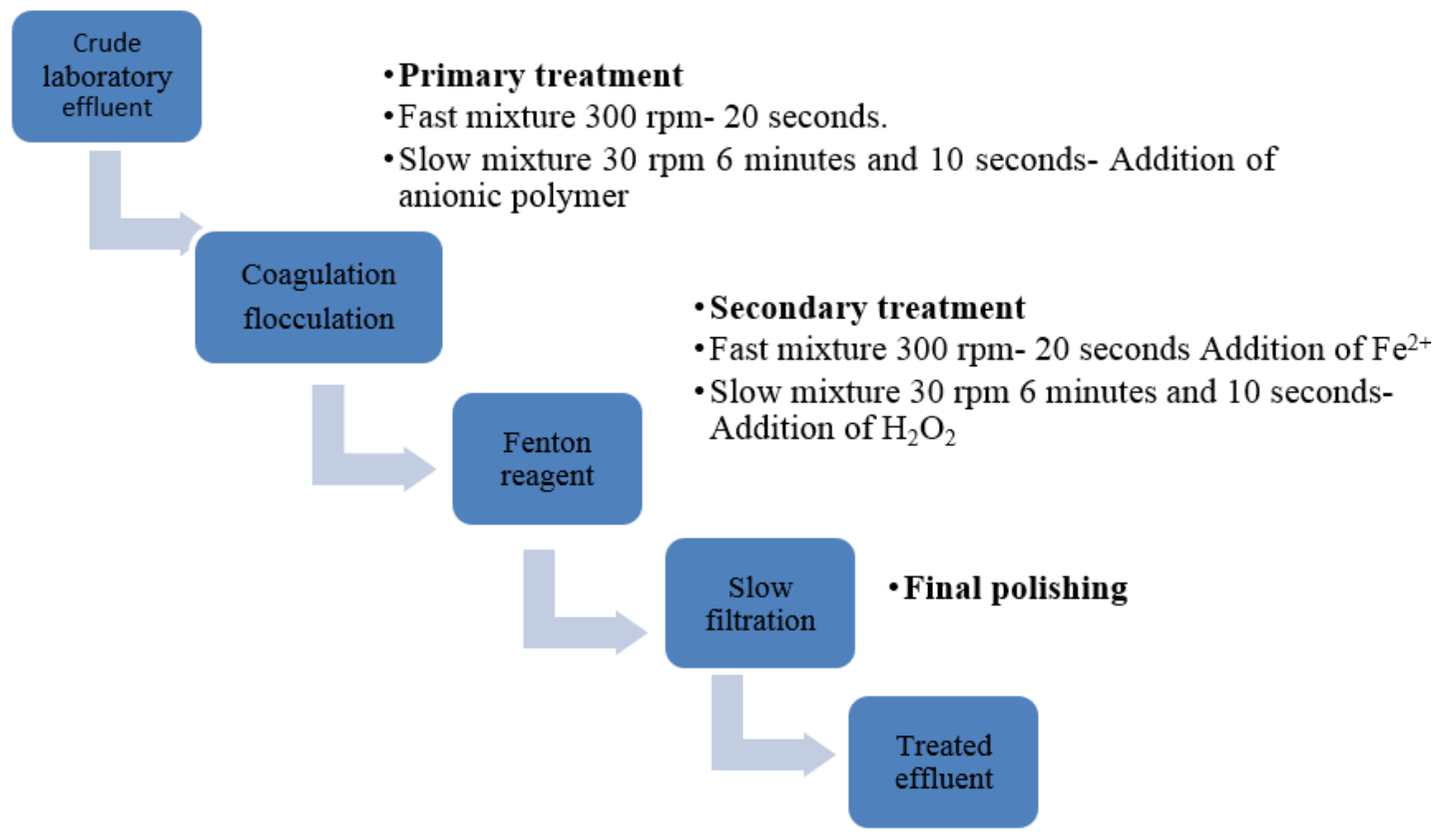

Figure 1. Treatment flowchart: Coagulation/flocculation, Fenton reagent and slow sand filtration.

As already explained, the studies began with the treatment technology through coagulation/flocculation so that a factorial experimental design $\left(2^{2}\right)$ planned for the variables: 
concentration of anionic polymer (0.60 and $1.40 \mathrm{mg} \mathrm{L}^{-1}$ ) and $\mathrm{pH}$ values (6.00 and 8.00); subsequently the dosage of chemical reagents for the coagulation/flocculation assays ranged from $0.00 \mathrm{mg} \mathrm{L}^{-1}$ to $2.00 \mathrm{mg} \mathrm{L}^{-1}$ of anionic polymer and the $\mathrm{pH}$ values varied from 3.00 to 10.00 .

Before starting the treatment with Fenton's reagent for the study, a factorial experimental design $\left(2^{3}\right)$ was planned for the variables: concentration of total soluble iron ( 2.33 and $\left.6.50 \mathrm{mg} \mathrm{L}^{-1}\right), \mathrm{pH}$ values (3.00 and 5.00) and concentration of peroxide of hydrogen (100.00 and $\left.200.00 \mathrm{mg} \mathrm{L}^{-1}\right)$; subsequently the concentration of chemical reagents ranged from $2.33 \mathrm{mg} \mathrm{L}^{-1}$ to $90.00 \mathrm{mg} \mathrm{L}^{-1}$ for total soluble iron concentration, $100.00 \mathrm{mg} \mathrm{L}^{-1}$ to $1200.00 \mathrm{mg} \mathrm{L}^{-1}$ for hydrogen peroxide concentration and the $\mathrm{pH}$ values varied from 3.00 to 5.50 .

The total treatment time was 400 minutes for the integration of the technologies. At the end of the combined treatment stages, the treatment efficiency was monitored through an environmental control system and further studies on classification of treated effluent for disposal and non-potable reuse purposes were carried out in compliance with the following resolutions: Conama (2005;2011), AGR (2009), ABNT (1997) and USEPA (2012).

\subsection{Characterization of crude effluent}

A characterization of effluent was carried out, which provided average and standard deviations from the calculations made with five different samples that are illustrated in Table 1 .

Table 1. Average values and standard deviation of the analyzed physicochemical parameters for crude laboratory liquid residue.

\begin{tabular}{lccc}
\hline Parameters & Values & $\begin{array}{c}\text { Crude laboratory } \\
\text { effluent }\end{array}$ & $\begin{array}{c}\text { Resolution } \\
\text { Conama (2005; 2011); AGR (2009) }\end{array}$ \\
\hline pH & Average & 1.73 & $5-9$ \\
Turbidity (NTU) & Standard deviation & 0.06 & $100 \mathrm{NTU}$ \\
& Average & 134.40 & \\
Absorbance (320nm) & Standard deviation & 24.96 & \\
& Average & 1.60 & $450.00 \mathrm{mg} \mathrm{O}_{2} \mathrm{~L}^{-1}$ \\
COD (mg O $\mathbf{~ L}^{-1}$ ) & Standard deviation & 0.40 & $15.00 \mathrm{mg} \mathrm{L}^{-1}$ \\
Soluble Total & Average & 1400.49 & \\
Residual Iron (mg L & Standard deviation & 436.53 & \\
\hline
\end{tabular}

The main parameter that needs to be monitored is the removal of the organic matter represented in this study by the COD. The Brazilian Resolution of 2011 (Conama, 2011) does not specify a COD value for effluent discharge, but only for BOD with a minimum removal of 60\%. The Brazilian Resolution of 2009 (AGR, 2009) stipulates a COD maximum value of $450.00 \mathrm{mg} \mathrm{O}_{2} \mathrm{~L}^{-1}$ for wastewater discharge. In this article, crude laboratory effluent had a COD value of, on average, $1400.49 \mathrm{mg} \mathrm{O}_{2} \mathrm{~L}^{-1}$, which is also outside the standards for hydraulic bodies.

In light of the data, we believe that the integration of the proposed technologies gives a promising opportunity for the treatment of recalcitrant effluents.

\section{RESULTS AND DISCUSSION}

\subsection{Coagulation/Flocculation treatment}

The most interesting results obtained in the preliminary tests $\left(2^{2}\right.$ factorial planning) were anionic polymer concentration $0.60 \mathrm{mg} \mathrm{L}^{-1}$ and $\mathrm{pH}$ value 6.00 (31.16\% COD removal), where the negative charges of the effective particles which led to chemical interactions were 
neutralized, thus causing the formation of flake and incurring a lower cost, compared with the high cost of the chemical reagents involved in the process.

After making a choice of these data, the variation of anionic polymer concentration was studied, with $\mathrm{pH}$ value fixed at 6.00 and concentration of total soluble iron $82.49 \mathrm{mg} \mathrm{L}^{-1}$ (natural concentrations of effluent) to obtain maximum efficiency in treatment, as can be seen in Figure 2.

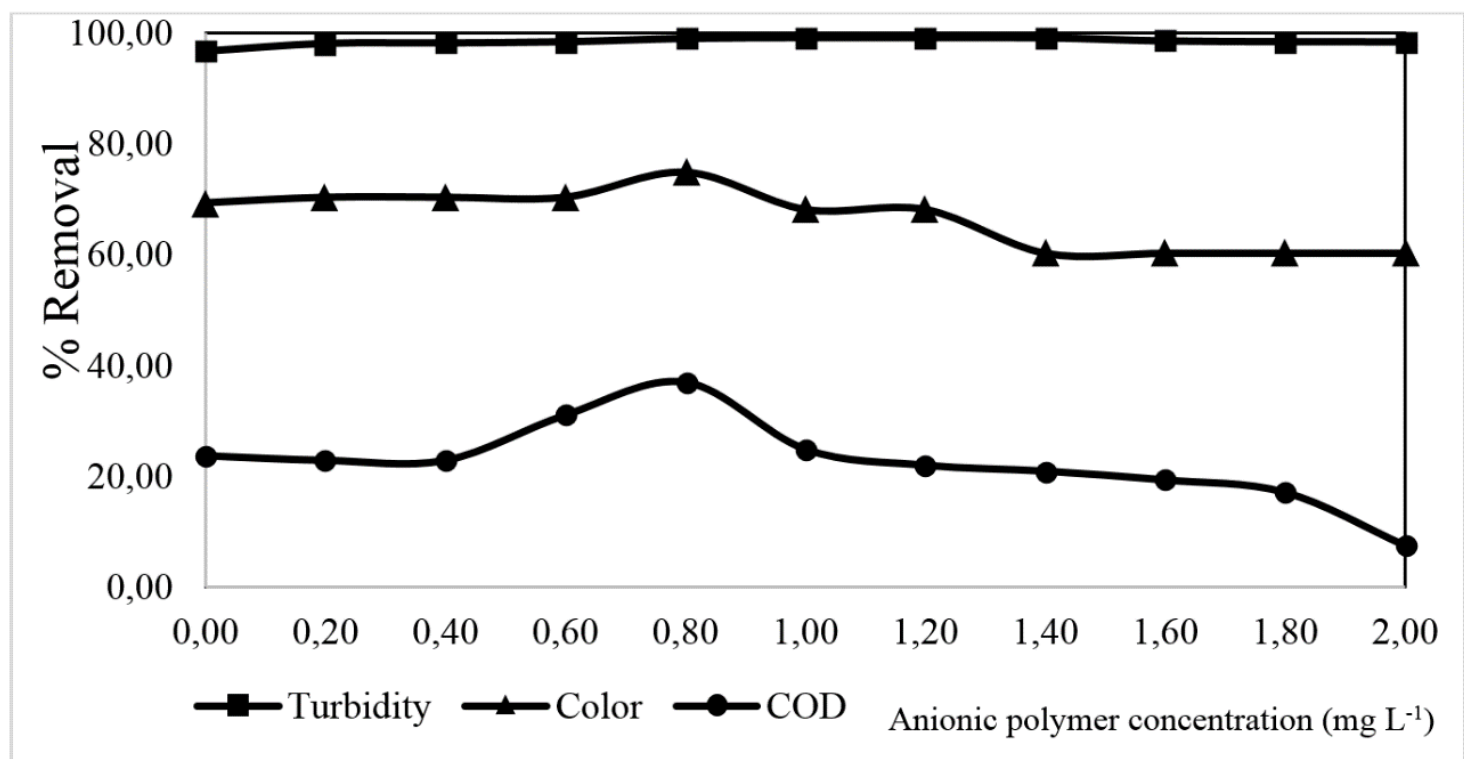

Figure 2. Effect of variation of anionic polymer concentration on COD, turbidity and absorbance removals by coagulation/flocculation treatment (pH 6.00 and residual total soluble iron $=82.49 \mathrm{mg} \mathrm{L}^{-1}$ ).

It can be observed in Figure 2 that COD removal remained constant at $23.00 \%$ up to $0.40 \mathrm{mg} \mathrm{L}^{-1}$, and it did not show any significant results in this range with the use of anionic polymer.

The removal of the organic matter increased around $11 \%$ when there was a concentration of polymeric anionic of $0.80 \mathrm{mg} \mathrm{L}^{-1}$, which is a considerable value for treating recalcitrant compounds.

It is worth noting that this dosage of polymeric anionic also contributes significantly to the cohesion of the flake, since a better interaction of the iron ions prevents them from being released into the water bodies (Shaikh et al., 2017). An example of this was the removal of iron (in these conditions) of $97.17 \%$. The initial iron concentration was $82.49 \mathrm{mg} \mathrm{L}^{-1}$ and the final concentration was $2.33 \mathrm{mg} \mathrm{L}^{-1}$. This is because the polymer chains are able to adopt multiple conformations on the adsorbent surface, which distinguishes their adsorption behavior from that of simple molecules and ions (Wiśniewska et al., 2016). In this way, the soluble iron concentration also reaches parameters for disposal that comply with Brazil Resolution 2011 (Conama, 2011) which provides a maximum of $15 \mathrm{mg} \mathrm{L}^{-1}$ of total iron for disposal in hydric bodies.

It was found that when there was a concentration above $1.00 \mathrm{mg} \mathrm{L}^{-1}$, it led to a reduction in the percentage of COD removal efficiency observed, which proves that an excess of anionic polymer led to an increase of solids, especially colloidal and particulate material. The excess of anionic polymers re-stabilizes the charge on colloidal particles by saturating its surface, damaging the formation of flocks in flocculation process and increasing the concentration of particulate matter in the effluent (Quartaroli et al., 2014). 
During the removal of the color as a result of absorbance, measured at the maximum absorption wavelength (spectral sweep) $320 \mathrm{~nm}$, it was noted that without the addition of an anionic polymer, a removal of $70.51 \%$ was obtained. With the addition of the anionic polymer, the maximum rate of efficiency for the removal of this parameter was $75.00 \%$, with $0.80 \mathrm{mg} \mathrm{L}^{-1}$ of anionic polymer. A decrease in the absorbance removal rate of efficiency of $1.00 \mathrm{mg} \mathrm{L}^{-1}$ resulted in an excess of anionic polymer which led to an increase of solids interfering with absorption of the medium, and hence color parameter (Quartaroliet al., 2014).

With regard to the analysis of turbidity, it was observed that the turbidity remained almost constant with a mean rate of removal for all concentrations of anionic polymer. It should be noted that without the addition of the anionic polymer, there is a removal efficiency rate of around $96.80 \%$, which is evidence that anionic polymer does not interfere in the removal of turbidity. It is only the presence of total soluble iron in residue and the suitable adjustment of $\mathrm{pH}$ that are sufficient for the removal of suspended and colloidal particles that cause turbidity in this effluent.

This fact can be explained by the formation of ferrous and ferric hydroxides of positive residual charge. These hydroxides, (also called gel), destabilize the colloidal particles of the effluent that possess a negative load, by reducing the potential Zeta and allow the approach and clustering of these particles, which characterizes the coagulation/flocculation process. It is also important to point out that there is a displacement of the chemical equilibrium when the $\mathrm{pH}$ increases to 6.00, which allows the formation of hydroxylated species, as is illustrated in Equation 1 (Morais and Brito 2016; Shaikh et al., 2017).

$\mathrm{Fe}^{2+}+2 \mathrm{H}_{2} \mathrm{O} \leftrightarrows \mathrm{Fe}(\mathrm{OH})_{2}+2 \mathrm{H}^{+}$

In view of the obtained data, it was confirmed that the optimum concentration of anionic polymer was $0.80 \mathrm{mg} \mathrm{L}^{-1}$, and an attempt was made to evaluate the influence of $\mathrm{pH}$ values on the efficiency of the treatment. At this stage, the $\mathrm{pH}$ values were found to be in the range of 3.00 to 10.00 with total soluble iron concentration of $82.49 \mathrm{mg} \mathrm{L}^{-1}$ and anionic polymer of $0.80 \mathrm{mg} \mathrm{L}^{-1}$ (Figure 3).

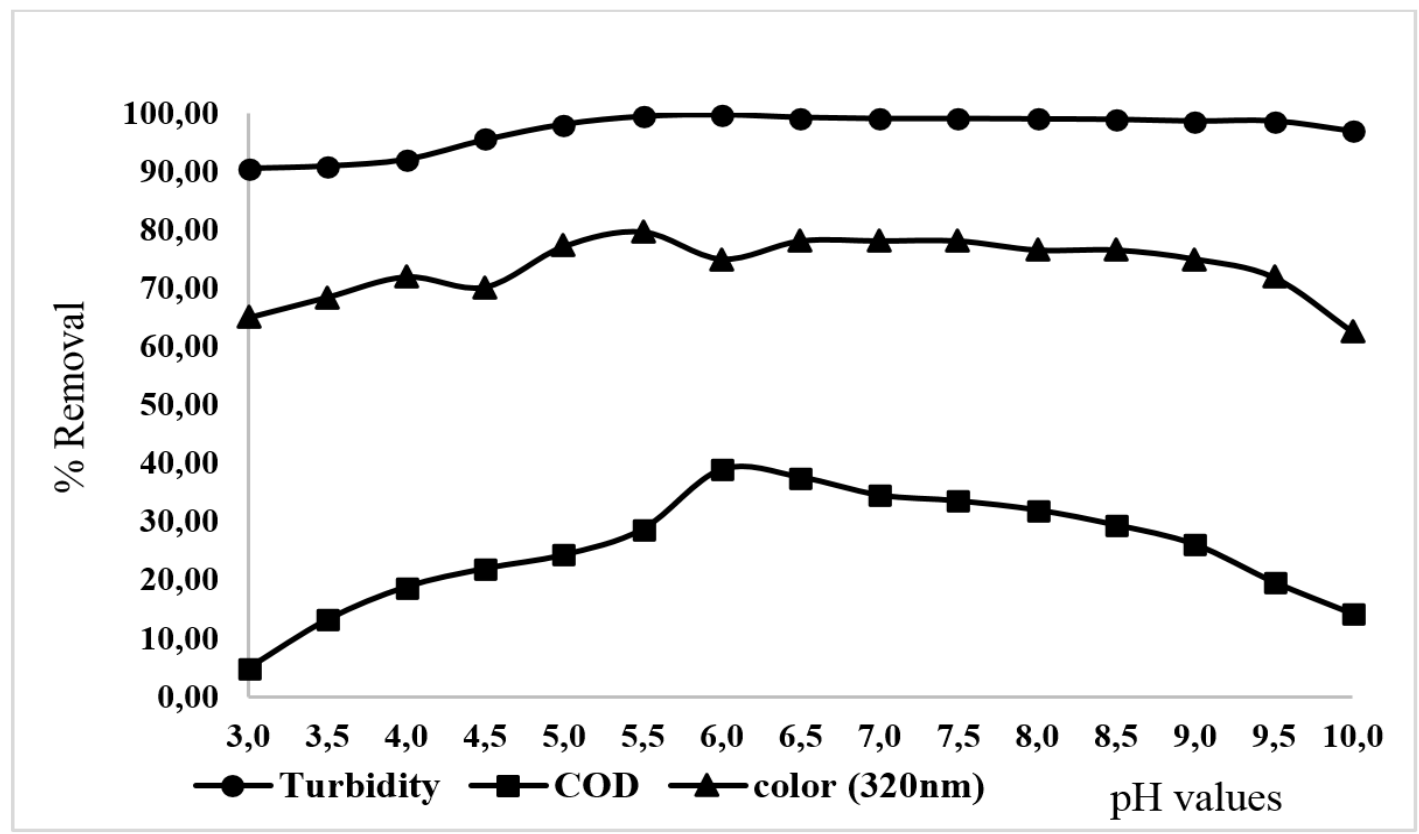

Figure 3. The effect of the variation of the $\mathrm{pH}$ values on COD, turbidity and absorbance removals for the treatment with coagulation/flocculation (total soluble iron $=82.49 \mathrm{mg} \mathrm{L}^{-1}$; anionic polymer $=0.80 \mathrm{mg} \mathrm{L}^{-1}$ ). 
In the case of the analysis of COD, the best percentage for removal (38.86\%) occurred at $\mathrm{pH}$ 6.00, because the polyacrylamide chains were completely ionized. As a result, there was an interaction of the anionic polymer with surface of flake mainly through the formation of hydrogen bonds between them (Wiśniewska et al., 2016).

The interactions between adsorbed species and surface hydroxyl groups, (whether protonated or not), altered the resulting charge of the particles and hence, the stability of suspension conditions. When $\mathrm{pH}$ of the solution is greater than the zero point charge of the solid in question (hydroxylated iron species), the surface of the solution becomes negative. This discourages electrostatic interactions with polyacrylamide polymer chains (since they contain completely dissociated carboxyl groups); this phenomenon may be occurring in this study when $\mathrm{pH}$ is above 6.00 (Wiśniewska et al., 2016).

With regard to the absorbance analysis at $320 \mathrm{~nm}$, it can be seen that the removal efficiency at $\mathrm{pH} 6.00$ was $75.00 \%$ on average, with removals up to $78.00 \%$ (pH values between $5.00-7.50$ ) which can also be visualized, although when analyzing a set of three parameters, the choice of the best $\mathrm{pH}$ value was 6.00. At $\mathrm{pH}$ less than 4.50, there is a decrease in removal efficiency, with a removal efficiency of $64.91 \%$.

When this occurs, low $\mathrm{pH}$ values (less than 5.00), and aquo-complexes $\left[\mathrm{Fe}\left(\mathrm{H}_{2} \mathrm{O}\right)_{6}\right]^{3+}$ are predominant, while the hydroxylated $\mathrm{Fe}(\mathrm{OH})^{2+}$ species is generally at a $\mathrm{pH}$ greater than 4.00 (Gama, 2012). The Fe $(\mathrm{OH})^{2+}$ species displays maximum absorbance with wavelengths of $300 \mathrm{~nm}$, extending up to approximately $400 \mathrm{~nm}$ (Nogueira et al., 2007).

In the case of the turbidity analysis, it can be observed in Figure 3 that the percentages or removals were similar to the $\mathrm{pH}$ values studied, with results of reduction around $99.00 \%$. A maximum removal rate at $\mathrm{pH} 6.00$ was obtained of around $99.72 \%$.

When there is $\mathrm{pH}$ of 3.00 to 5.50 , turbidity has a smaller point of removal. It has been shown that at higher $\mathrm{pH}$ values ( $>5.50$ ), a displacement of the hydrolysis equilibrium of iron ions is achieved, leading to the formation of iron hydroxides that are essential for the interaction with colloids and formation of flakes (Guo et al., 2010).

A better operating condition was obtained from the results of the $\mathrm{pH}$ variation, where $82.49 \mathrm{mg} \mathrm{L}^{-1}$ of total soluble iron and $0.80 \mathrm{mg} \mathrm{L}^{-1}$ of anionic polymer were used in a $\mathrm{pH}$ value of 6.00; this made it possible to reach COD removals of $38.86 \%$, turbidity of $99.72 \%$ and absorbance of $75.00 \%$.

After the coagulation/flocculation treatment and the results were obtained for $\mathrm{pH}$ value, the turbidity and total iron were in accordance with the effluent release standards established by Brazil 2011 (Conama, 2011), with the exception of the COD parameter (856.26 $\mathrm{mg} \mathrm{O}_{2} \mathrm{~L}^{-1}$ ) that had values above those allowed by the Brazil 2009 Resolution (AGR, 2009), at $450.00 \mathrm{mg} \mathrm{O}_{2} \mathrm{~L}^{-1}$.

Thus, treatment must be provided via the Fenton reagent that can be combined with the coagulation/flocculation process, mainly to reduce the values related to chemical oxygen demand, that even after treatment by coagulation/flocculation still fail to meet the current standards for the discharge of effluents in water bodies, and hence would not be suitable for reuse for non-potable purposes.

\subsection{Fenton reagent treatment}

After the coagulation/flocculation treatment, the best test obtained from the Fenton reagent assays, was used to meet the standards and established values laid down by the studied resolutions. The residual total soluble iron $2.33 \mathrm{mg} \mathrm{L}^{-1}$ obtained from the previous treatment (coagulation / flocculation) was used for the factorial design, which avoided the unnecessary use of chemical reagents. 
Preliminary tests were conducted using a $2^{3}$ factorial planning design (two levels and three variables), since this had the highest removal efficiency for COD (29.82\%), and is the most important parameter, given the difficulty of its removal and its estimated representation of organic matter. In the case of the other parameters, the results were turbidity $(65.00 \%)$, absorbance (40.00\%) and final $\mathrm{pH}$ of 2.83. In this experiment, $6.50 \mathrm{mg} \mathrm{L}^{-1}$ of total soluble iron and $200.00 \mathrm{mg} \mathrm{L}^{-1}$ of $\mathrm{H}_{2} \mathrm{O}_{2}$ were used at an initial $\mathrm{pH}$ of 3.00 .

From the data produced by the factorial design, the total soluble iron concentration, $\mathrm{H}_{2} \mathrm{O}_{2}$ and $\mathrm{pH}$ values were varied to determine the best conditions for the Fenton reaction in the treatment of laboratory effluent after coagulation/flocculation, starting with a concentration of total soluble iron (2.33 to $90.00 \mathrm{mg} \mathrm{L}^{-1}$ ) maintaining $\mathrm{H}_{2} \mathrm{O}_{2}$ at $200.00 \mathrm{mg} \mathrm{L}^{-1}$ and $\mathrm{pH}$ at 3.00 .

In Figure 4, it was clear that the COD removal values had maximum values in $13.00 \mathrm{mg} \mathrm{L}^{-1}$ concentration of total soluble iron (COD 32.37\%). When concentrations below $13.00 \mathrm{mg} \mathrm{L}^{-1}$ of total soluble iron were analyzed, there was a loss of efficiency, caused by the low concentration of iron species capable of reacting with $\mathrm{H}_{2} \mathrm{O}_{2}$, and this reduced the generation of hydroxyl radicals in the medium.

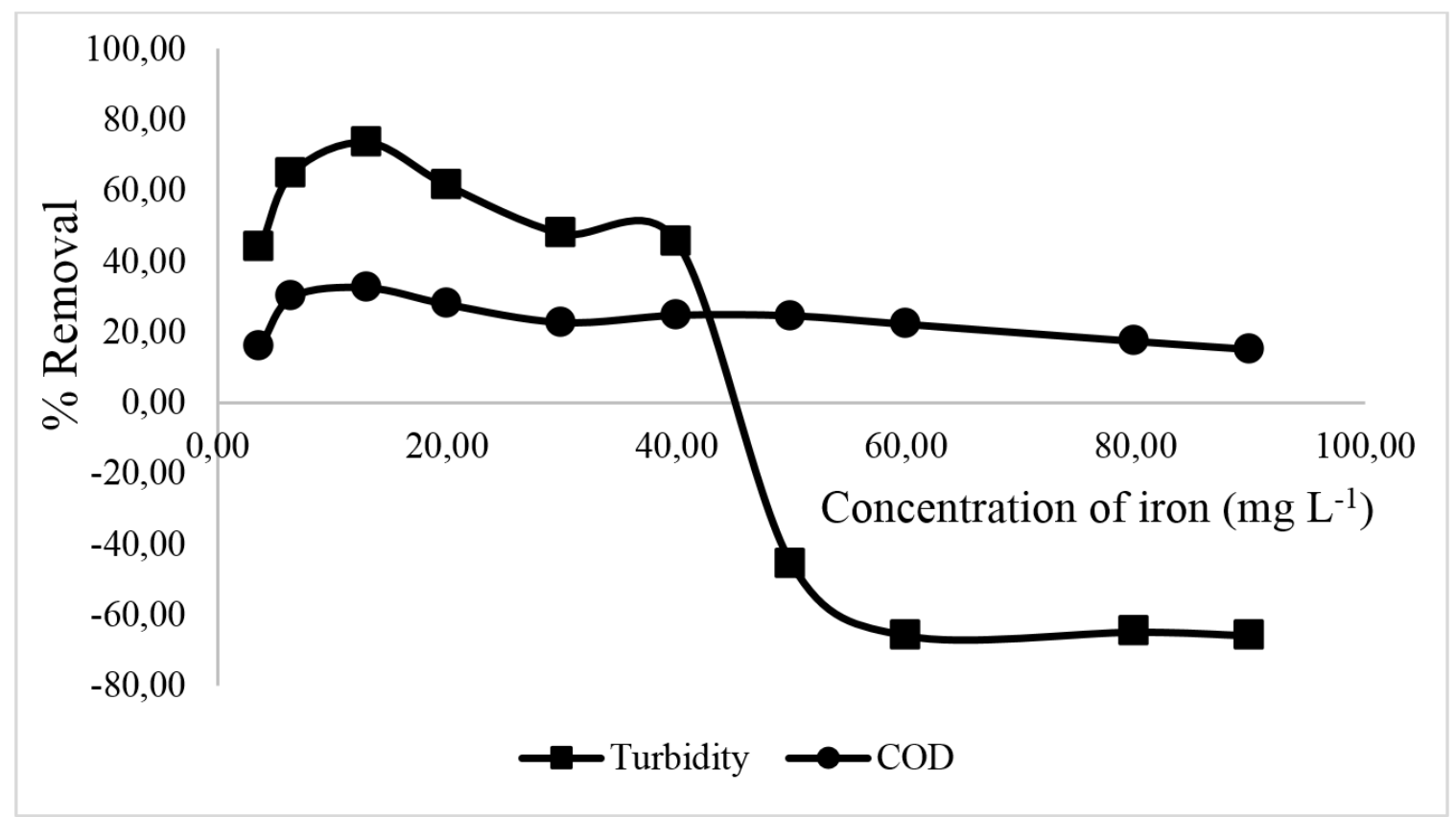

Figure 4. Effect of total soluble iron concentration on COD and turbidity removals through treatment with the Fenton reagent $\left(\mathrm{H}_{2} \mathrm{O}_{2}=200.00 \mathrm{mg} \mathrm{L}^{-1}\right.$, $\left.\mathrm{pH} 3.00\right)$. Note: the negative (-) signals represent an increase in value of the parameter in question.

When going beyond a concentration of $13.00 \mathrm{mg} \mathrm{L}^{-1}$, there begins to be a decline in efficiency in the removal of organic matter. This is due to an increase in concentration of $\mathrm{Fe}^{+2}$ that sequesters hydroxyl radicals, producing $\mathrm{Fe}^{3+}$ and $\mathrm{OH}^{-}$ions, as expressed in Equation 2 (Ma and Xia, 2009).

$\mathrm{Fe}^{2+}+\mathrm{HO}^{\bullet} \rightarrow \mathrm{Fe}^{3+}+\mathrm{HO}^{-}$

$$
\mathrm{K}=2.5-5 \times 10^{8} \mathrm{~L} \mathrm{~mol}^{-1} \mathrm{~s}^{-1}
$$

Because the kinetic constant $\left(2.5-5 \times 10^{8} \mathrm{~L} \mathrm{~mol}^{-1} \mathrm{~s}^{-1}\right)$ is higher than the Fenton reaction Phase 1 reaction (Equation 2), the excess of $\mathrm{Fe}^{+2}$ in the system prefers the reaction represented by Equation 1 to the reaction of Equation 3, which confirms the negative result of the high increase in the concentration of $\mathrm{Fe}^{+2}$ in the treatment.

$\mathrm{Fe}^{2+}+\mathrm{H}_{2} \mathrm{O}_{2}+\mathrm{H}^{+} \rightarrow \mathrm{Fe}^{3+}+\mathrm{HO}^{\bullet}+\mathrm{H}_{2} \mathrm{O}$

40-80 $\mathrm{L} \mathrm{mol}^{-1} \mathrm{~s}^{-1}$

\section{IPABH}

Rev. Ambient. Água vol. 13 n. 5, e2243 - Taubaté 2018 
In an analysis of turbidity, it can be seen that an excessive increase of concentration of $\mathrm{Fe}^{+2}$ leads to a decrease in efficiency with regard to the removal of suspended/colloidal particles; this is shown in the graph of Figure 4, where there is a concentration of around $50.00 \mathrm{mg} \mathrm{L}^{-1}$ of total soluble iron. This behavior can be explained by the oxidation of $\mathrm{Fe}^{+2}$ to $\mathrm{Fe}^{+3}$ which, by hydrolysis in aqueous solution, leads to the formation of iron and ferric hydroxides, which cause increased turbidity in the treated effluent, as shown in Equations 4, 5 and 6 (Morais and Brito, 2016).

$$
\begin{aligned}
& \mathrm{Fe}^{3+}+6 \mathrm{H}_{2} \mathrm{O} \leftrightarrows\left[\mathrm{Fe}\left(\mathrm{H}_{2} \mathrm{O}\right)_{6}\right]^{3+} \\
& {\left[\mathrm{Fe}\left(\mathrm{H}_{2} \mathrm{O}\right)_{6}\right]^{3+}+\mathrm{H}_{2} \mathrm{O} \leftrightarrows\left[\mathrm{Fe}\left(\mathrm{H}_{2} \mathrm{O}\right)_{5} \mathrm{OH}\right]^{2+}+\mathrm{H}_{3} \mathrm{O}^{+}} \\
& {\left[\mathrm{Fe}\left(\mathrm{H}_{2} \mathrm{O}\right)_{5} \mathrm{OH}\right]^{2+}+\mathrm{H}_{2} \mathrm{O} \leftrightarrows\left[\mathrm{Fe}\left(\mathrm{H}_{2} \mathrm{O}\right)_{4}(\mathrm{OH})_{2}\right]^{+}+\mathrm{H}_{3} \mathrm{O}^{+}}
\end{aligned}
$$

Figure 4 shows that keeping the concentration of $\mathrm{H}_{2} \mathrm{O}_{2}$ at $200.00 \mathrm{mg} \mathrm{L}^{-1}$ and $\mathrm{pH} 3.00$ with a concentration of total soluble iron at $13.00 \mathrm{mg} \mathrm{L}^{-1}$ enabled the removal of COD to reach around $32.37 \%$, with turbidity of $73.53 \%$ and final $\mathrm{pH}$ of 2.95 . At the end of the treatment, the residual total soluble iron concentration was found to be $6.40 \mathrm{mg} \mathrm{L}^{-1}$, which is within the release standards established by Brazil (Conama, 2011) (i.e., $15.00 \mathrm{mg} \mathrm{L}^{-1}$.).

In the next stage of the treatment, the influence of $\mathrm{pH}$ values was evaluated, and values of total soluble iron at $13.00 \mathrm{mg} \mathrm{L}^{-1}$ and $\mathrm{H}_{2} \mathrm{O}_{2}$ at $200.00 \mathrm{mg} \mathrm{L}^{-1}$ (Figure 5) were maintained.

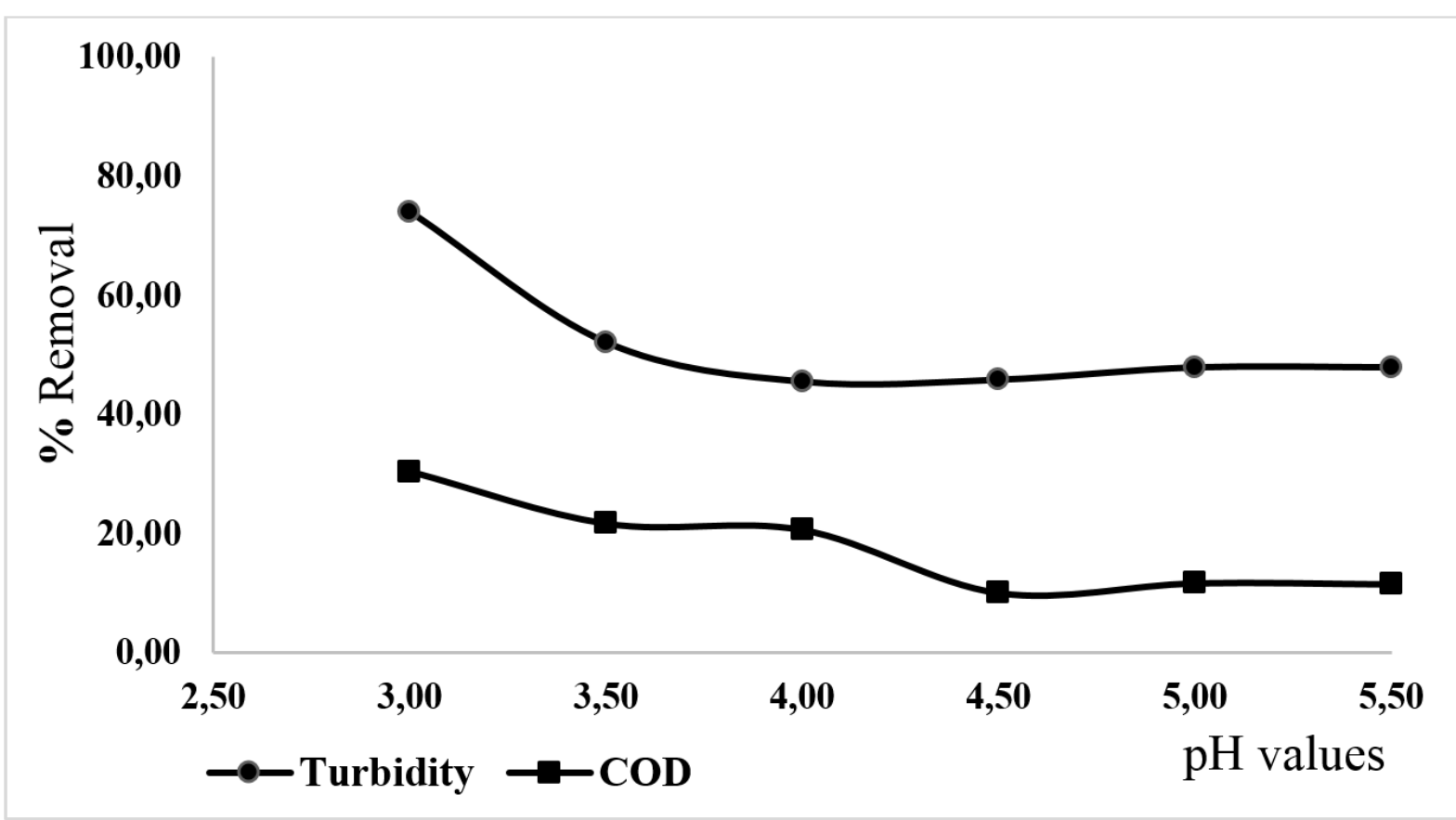

Figure 5. Effect of the variation of the $\mathrm{pH}$ values on $\mathrm{COD}$ and turbidity removals for the treatment with Fenton reagent (total soluble iron $=13.00 \mathrm{mg} \mathrm{L}^{-1} ; \mathrm{H}_{2} \mathrm{O}_{2}=200.00 \mathrm{mg} \mathrm{L}^{-1}$ ).

The efficiency removal rates of COD values (30.40\%) and turbidity (74.00\%), showed maximum values at $\mathrm{pH} 3.00$. The treatment has a higher degree of efficiency in the acid range between $\mathrm{pH} 3-4$, by directly increasing the concentration of $\mathrm{Fe}^{2+}$ in solution and the availability of the hydroxyl radicals in the medium (Lin et al., 2016).

The efficiency of Fenton reagent depends on the formation of the hydroxyl radicals shown in Equation 3 and the increase of $\mathrm{H}^{+}$ions induces the consumption of $\mathrm{OH}^{-}$ions by undergoing a displacement in the equation for the formation of hydroxyl radicals (Mirzaei et al., 2017). 
When there was a $\mathrm{pH}$ value higher than 4.50, a decrease in COD removal percentage was observed, owing to the decrease of free iron species, together with formation of complex species and iron precipitates, as well as the degradation of $\mathrm{H}_{2} \mathrm{O}_{2}$ to $\mathrm{O}_{2}$ and $\mathrm{H}_{2} \mathrm{O}$ or the formation of anion $\mathrm{HO}_{2}{ }^{-}$(Torradesa and Montañob, 2014). In conditions when there are neutral $\mathrm{pH}$ values, the reduction of $\mathrm{H}^{+}$ions is induced, which reduces the productive efficiency of the hydroxyl radical.

According to Nogueira et al. (2007), when the $\mathrm{pH}$ value is smaller than 3.00, the rate of degradation also decreases, although iron species remains soluble, since high concentrations of $\mathrm{H}^{+}$can sequester hydroxyl radicals, as shown in Equation 7:
$\mathrm{HO}^{\bullet}+\mathrm{H}^{+}+e^{-} \rightarrow \mathrm{H}_{2} \mathrm{O}$
$7 \times 10^{9} \mathrm{~L} \mathrm{~mol}^{-1} \mathrm{~s}^{-1}$

In the last stage of Fenton's reagent, different concentrations of $\mathrm{H}_{2} \mathrm{O}_{2}$ were observed with constant values of total soluble iron of $13.00 \mathrm{mg} \mathrm{L}^{-1}$ and $\mathrm{pH} 3.00$. The results for the variations of hydrogen peroxide are shown in Figure 6.

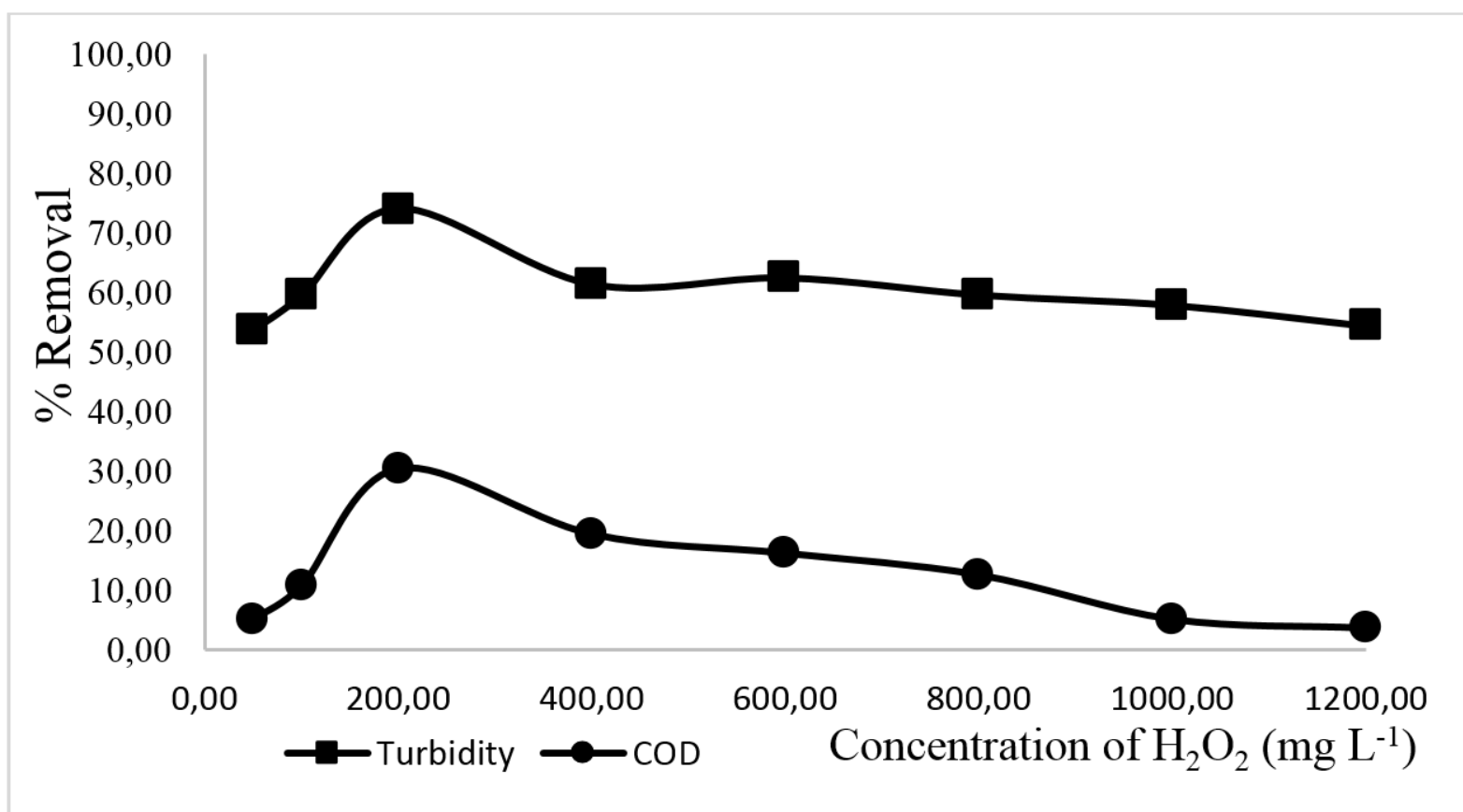

Figure 6. Effect of $\mathrm{H}_{2} \mathrm{O}_{2}$ concentration on COD and turbidity removals through treatment with Fenton reagent (Total soluble iron $=13.00 \mathrm{mg} \mathrm{L}^{-1}$, $\mathrm{pH} 3.00$ ).

In the analysis of Figure 6, it was confirmed that concentrations of $200.00 \mathrm{mg} \mathrm{L}^{-1}$ of $\mathrm{H}_{2} \mathrm{O}_{2}$ increase the removal of COD and turbidity; COD has a reduction efficiency of $30.40 \%$ and turbidity of $74.00 \%$. Values greater than $200.00 \mathrm{mg} \mathrm{L}^{-1}$ reduce the removal efficiency, and have a negative effect on a high concentration of hydrogen peroxide, which reacts with hydroxyl radical and forms a hydroperoxyl radical (Equation 8) (Brito et al., 2010).

$$
\mathrm{HO}^{\bullet}+\mathrm{H}_{2} \mathrm{O}_{2} \rightarrow \mathrm{HO}_{2}^{\bullet}+\mathrm{H}_{2} \mathrm{O} \quad \mathrm{K}=1.7-4.5 \times 10^{7} \mathrm{~L} \mathrm{~mol}^{-1} \mathrm{~s}^{-1}
$$

In addition to reacting to hydrogen peroxide, as is shown in Equation 9, hydroxyl radicals can react with each other, by regenerating hydrogen peroxide (eq 9), and reducing concentrations of the radical in the medium and reducing the efficiency of the Fenton reaction (Brito et al., 2010).

\section{IPABH}


$\mathrm{HO}^{\bullet}+\mathrm{HO}^{\bullet} \rightarrow \mathrm{H}_{2} \mathrm{O}_{2}$

$\mathrm{K}=5-8 \times 10^{9} \mathrm{~L} \mathrm{~mol}^{-1} \mathrm{~s}^{-1}$

Ragasson (2013) specifies that the typical ratio of $\left[\mathrm{Fe}^{+2}\right]$ and $\left[\mathrm{H}_{2} \mathrm{O}_{2}\right]$ is in the range of 1:5 to 1:10 for greater efficiency of Fenton reagent; however, this ratio depends on the nature of the effluent and its organic load.

After the reagent Fenton treatment for laboratory effluent, the relation between $\mathrm{Fe}^{2+}$ ions and hydrogen peroxide was 1:15.38.

These concentrations was varied to determine the ideal concentrations of iron and hydrogen peroxide, which are always around the ratio 1:15 of soluble iron and hydrogen peroxide (the best ratio that has been found in this article), as shown in Figure 7.

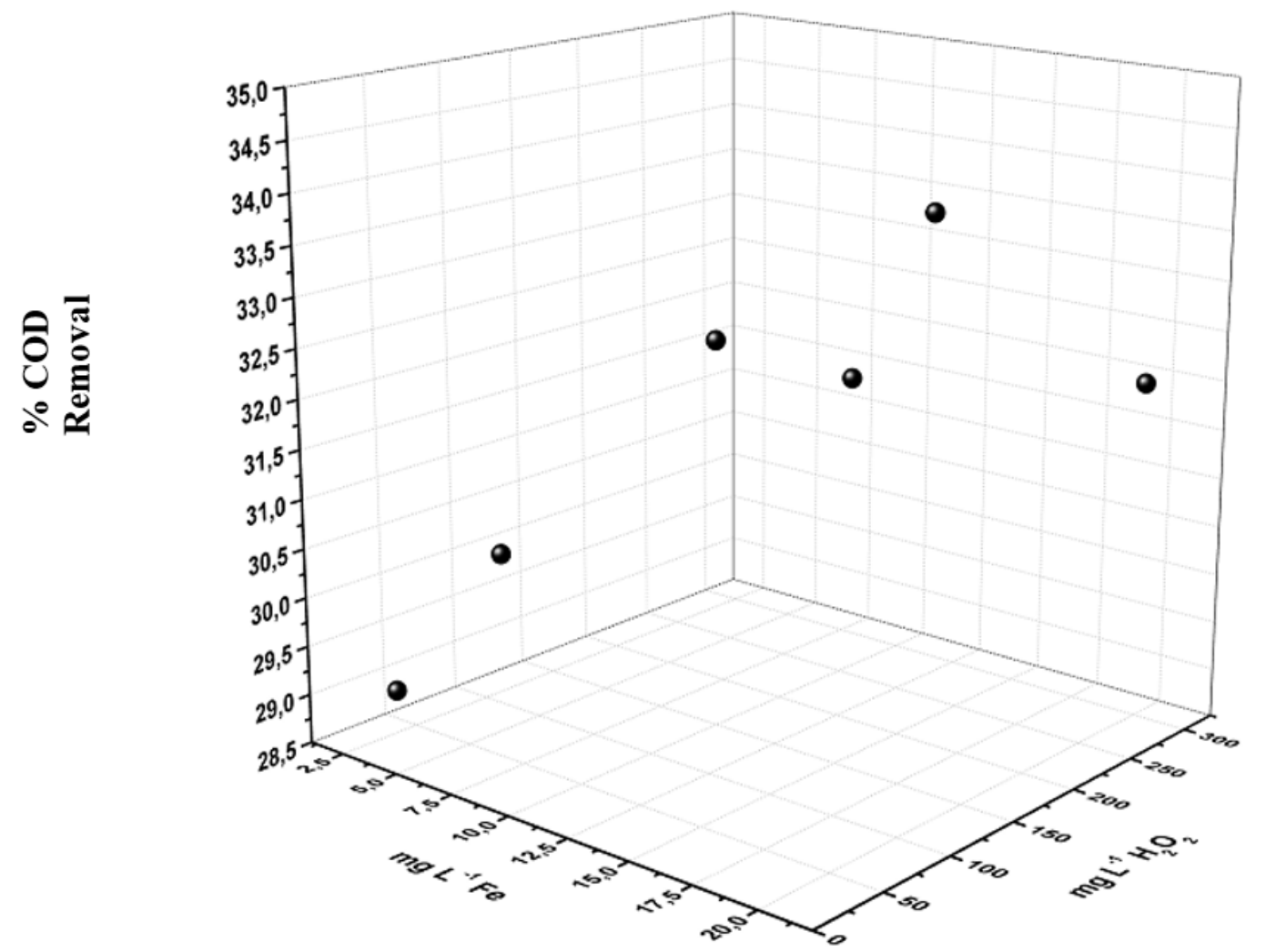

Figure 7. Study of Fe: $\mathrm{H}_{2} \mathrm{O}_{2}$ ratio in COD removal using the ratio obtained (1:15).

From the perspective of the Fe: $\mathrm{H}_{2} \mathrm{O}_{2}$ (ratio of 1:15) COD removals ranged from $28.94 \%$ to $33.70 \%$. It was decided to keep total soluble iron concentrations of $13.00 \mathrm{mg} \mathrm{L}^{-1}$ and $\mathrm{H}_{2} \mathrm{O}_{2}$ of $200.00 \mathrm{mg} \mathrm{L}^{-1}$ with a removal percentage of around 32.05\% COD. At concentrations of 15.00 mg L ${ }^{-1}$ of total soluble iron and $\mathrm{H}_{2} \mathrm{O}_{2}$ of $225.00 \mathrm{mg} \mathrm{L}^{-1}$, a COD removal of $33.70 \%$ was achieved; however, the increase of only $2.00 \%$ does not compensate for the extra expense of the chemical reagents.

The selected concentration of $13.00 \mathrm{mg} \mathrm{L}^{-1}$ of total soluble iron may indicate whether there was removal of iron at the end of the slow filtration, by taking into account the assimilation of iron and manganese by the microbial consortium formed at the top of the layer of the filter bed called "schmutzdecke" and the adsorption of metals in microbial beds and from the formed biofilm in the sand layers (Arantes et al., 2014).

On the basis of the study of the variables that had a direct influence on Fenton's reagent treatment, it could be concluded what was the optimal concentration in removal of both COD (30.40\%) and turbidity (74.00\%) - using $200.00 \mathrm{mg} \mathrm{L}^{-1}$ of hydrogen peroxide and $13.00 \mathrm{mg} \mathrm{L}^{-1}$ of total soluble iron. With regard to $\mathrm{pH}$, its greater efficiency was obtained at a 
3.00 value. The final $\mathrm{pH}$ value after treatment was 2.95. The residual iron had a value of $6.67 \mathrm{mg} \mathrm{L}^{-1}$ and residual $\mathrm{H}_{2} \mathrm{O}_{2}$ of $0.42 \mathrm{mg} \mathrm{L}^{-1}$.

After the treatments, there continued to be a problem concerning the discharge of the organic matter, which reached a COD value of $595.95 \mathrm{mg} \mathrm{O}_{2} \mathrm{~L}^{-1}$, and thus failed to reach the minimum value (450.00 $\mathrm{mgO}_{2} \mathrm{~L}^{-1}$ ) stipulated by the Brazilian Resolution of 2009 (AGR, 2009). For this reason, the use of combined slow filtration with coagulation/flocculation processes was recommended together with the Fenton reagent discussed above. This was used for final polishing with the aim of meeting current standards of effluent release in water bodies and, perhaps later, the end of reuse for non-potable purposes.

\subsection{Slow Filtration Treatment}

After the treatment by Fenton reaction, the $\mathrm{pH}$ was raised to 7.00. The $\mathrm{pH}$ around 7.00 favors the growth of microorganisms that are essential for the development of the biological layer ("schmutzdecke") at the top of sand layer and benefits from a good performance of the slow filter (Nascimento et al., 2012).

The main parameter, which is still failing to comply with federal legislation regarding COD, reached a parameter for disposal ranging from $595.95 \mathrm{mg} \mathrm{O}_{2} \mathrm{~L}^{-1}$ to $346.21 \mathrm{mg} \mathrm{O}_{2} \mathrm{~L}^{-1}$ in the best treatment batch.

After the fourth treatment batch, the slow filter starts the clogging process and it is necessary to clean the non-woven synthetic blankets on top of the sand filter layer before starting treatment again.

After the integration of technologies in these studies, the following analyses were performed before and after proposed treatments and properly discussed as follows.

\subsection{Analysis of the Parameters Investigated}

In the study of $\mathrm{pH}$ values, it was observed that after the treatment by coagulation/flocculation, there is a reduction of the $\mathrm{pH}$ value which achieves a final value of 5.81. This is due to hydrolysis of iron which releases protons $\left(\mathrm{H}^{+}\right)$during the formation of hydroxylating species of iron in the reaction medium (Marcionilio et al., 2015).

In the treatment of the Fenton reagent, the initial $\mathrm{pH}$ value was 3.00, but at the end of the process, this value changed to 2.95. This reduction is due to the release of $\mathrm{H}^{+}$ions during the regeneration process of the catalyst represented in Equations 10 and 11 (Sohrabi et al., 2017).

$$
\begin{aligned}
& \mathrm{Fe}^{3+}+\mathrm{H}_{2} \mathrm{O}_{2} \rightarrow \mathrm{FeOOH}^{2+}+\mathrm{H}^{+} \quad \mathrm{K}=0.001-0.01 \mathrm{~L} \mathrm{~mol}^{-1} \mathrm{~s}^{-1} \\
& \mathrm{FeOOH}^{2+} \rightarrow \mathrm{Fe}^{2+}+\mathrm{HO}_{2}^{\bullet} \quad \mathrm{K}=2.7 \times 10^{-3} \mathrm{~L} \mathrm{~mol}^{-1} \mathrm{~s}^{-1}
\end{aligned}
$$

The decomposition of the hydroperoxyl radical also triggers the release of protons in medium (Equation 12) (Giannakis et al., 2016).

$$
\mathrm{HO}_{2}^{\bullet} \rightarrow\left(\mathrm{O}_{2}^{\circ-}\right)+H^{+} \quad \mathrm{K}=1.58 \times 10^{5} \mathrm{~L} \mathrm{~mol}^{-1} \mathrm{~s}^{-1}
$$

The reaction between ferric ion and the hydroperoxyl radical also leads to the regeneration of ferrous ions with a release of oxygen gas and $\mathrm{H}^{+}$ions, as expressed in Equation 13 (Babuponnusami and Muthukumar, 2014).

$$
\mathrm{Fe}^{3+}+\mathrm{HO}_{2}^{\bullet} \rightarrow \mathrm{Fe}^{2+}+\mathrm{O}_{2}+\mathrm{H}^{+} \quad \mathrm{K}=0.33-2.1 \times 10^{6} \mathrm{~L} \mathrm{~mol}^{-1} \mathrm{~s}^{-1}
$$

At the end of the integration of the treatment technologies, the final $\mathrm{pH}$ value was 6.93, which is within the allowed range for disposal (between 5-9) according to Brazilian legislation (Pompei et al., 2017). 
With regard to the absorbance analysis, it should be noted that at a wavelength of $320 \mathrm{~nm}$ researchers have found the presence of aromatic rings in solution. In addition, it is reported that at wavelengths of 200 to $300 \mathrm{~nm}$, the main structures are carbonyl, carboxyl, nitroso and nitrite. At $292 \mathrm{~nm}$, the most likely compounds are: aromatic amino acids and highly conjugated aliphatic chain volatile compounds, at $328 \mathrm{~nm}$ naphthalene and its derivatives (Hu and Wang, 2017).

Colored organic compounds have a chromophore group attached to a conjugated double bonds system. These chromophoric groups have unsaturated bonds such as $\mathrm{C}=\mathrm{O}$ and $\mathrm{N}=\mathrm{N}$ (Durigan et al., 2012).

Within this scenario for absorbance analysis, it was noted that during the post-reaction Fenton treatment, there was an increase of $65.71 \%$ of absorbance at $200 \mathrm{~nm}$, possibly owing to the generation of intermediates that are strongly absorbent at this wavelength. According to $\mathrm{Hu}$ and Wang (2017), at 200-250 nm absorbance, the values may represent carboxyl functional groups that are strongly absorbent in this range.

The overall final removals of absorbance in this study were $83.50 \%$ at $200 \mathrm{~nm}$ and $86.25 \%$ at $320 \mathrm{~nm}$ for 400 minutes of treatment.

With regard to the turbidity analysis, the crude effluent showed a value of $134.40 \mathrm{NTU}$, and the final value obtained was 0.78 NTU in accordance with the limits allowed by Brazil 2005 (Conama, 2005), which establishes a value below 40.00 NTU in Class 1 waters. After crude laboratory effluent is treated by the coagulation/flocculation process, it already acquires a value of $4.1 \mathrm{NTU}$, which is within the limits imposed by federal legislation. After integrating three technologies, it was possible to obtain $99.41 \%$ of the removal value of this analytical parameter.

In the analysis of total soluble iron, the treated laboratory effluent had a total residual soluble iron concentration of $0.56 \mathrm{mg} \mathrm{L}^{-1}$, after combined treatments. Compared with the crude laboratory effluent, this value obtained a reduction of $99.32 \%$ with regard to the initial concentration of total soluble iron (82.49 $\mathrm{mg} \mathrm{L}^{-1}$ ).

In the same way as in the first turbidity stage of coagulation/flocculation treatment, the greatest removal value of this parameter (iron) was $96.19 \%$. This was due to the formation of iron hydroxylating species that interacts with colloids of medium to form cohesive flakes with good sedimentability; the action of the anionic polymer is of considerable importance for the interaction of the $\mathrm{Fe}^{2+} / \mathrm{Fe}^{3+}$ ions and reducing their availability to aqueous medium (Ma and Xia, 2009).

The slow filtration process is also responsible for the removal of iron that enters in the treatment system with a concentration of $7.54 \mathrm{mg} \mathrm{L}^{-1}$ and has a final value of $0.56 \mathrm{mg} \mathrm{L}^{-1}$. The processes of straining, sedimentation, inertial impaction, interception, adhesion, flocculation, diffusion, adsorption and biological activity (a microbial consortium called "schmutzdecke", which is described above and which consumes iron and manganese) have been suggested as mechanisms that can be employed for contaminant removal in slow filtration (Bagundol et al., 2013). In this way, soluble iron concentration also reaches parameters for disposal that comply with Resolution Brazil 2011 (Conama, 2011) which provides a maximum of $15 \mathrm{mg} \mathrm{L}^{-1}$ of total iron for disposal in hidric bodies.

The Residual hydrogen peroxide in crude laboratory effluent had a concentration of $1.13 \mathrm{mg} \mathrm{L}^{-1}$. During the second stage, the Fenton reaction added $200.00 \mathrm{mg} \mathrm{L}^{-1}$ of $_{2} \mathrm{H}_{2}$ where almost all of the $\mathrm{H}_{2} \mathrm{O}_{2}$ was consumed during the homogeneous catalytic process (phase 1 of Fenton Equation 3) with a final concentration after the Fenton reaction of $0.41 \mathrm{mg} \mathrm{L}^{-1}$ and overall removal with combination treatments of $92.92 \%$.

The removal of this value is extremely important because hydrogen peroxide is an oxidizing agent $(1.42 \mathrm{~V})$ that can continue the process of oxidation in aqueous medium if it 
does not decompose rapidly in water and molecular oxygen (Brito et al., 2015). In addition, the high presence of $\mathrm{H}_{2} \mathrm{O}_{2}$ prevents a visualization of spectral changes in wavelengths between 200$300 \mathrm{~nm}$, although in this article it was possible to determine the decrease of signals in these regions, which may indicate a degradation of aromatic intermediates (Salvador et al., 2012).

Through the analysis of the Chemical Oxygen Demand, it was possible to achieve an overall removal of $75.27 \%$ with a final COD of $346.21 \mathrm{mg} \mathrm{O}_{2} \mathrm{~L}^{-1}$, thus obtaining a parameter for disposal that is in compliance with Brazilian Resolution 2009 (AGR, 2009), which recommends a final disposal of COD in the order of $450.00 \mathrm{mg} \mathrm{O}_{2} \mathrm{~L}^{-1}$. The Fenton reaction, which is technology that involves the oxidation of organic matter, contributed to $30.40 \%$ of the removal. Fenton's reagent is an extremely promising remediation technology because it has a relatively low cost and high degree of efficiency compared with other advanced oxidations.

The dissolved oxygen (DO) analysis in crude laboratory effluent showed a value of $1.70 \mathrm{mg} \mathrm{L}^{-1}$, a value that can be explained by the high organic load and oils and greases present in the studied effluent. After treatment with Fenton's reagent, the final dissolved oxygen concentration was $4.70 \mathrm{mg} \mathrm{L}^{-1}$, which is an increase of $63.82 \%$ in the value of this parameter.

The intermediate reactions of the Fenton process explains the increase of $\mathrm{O}_{2}$ concentration in the treated wastewater, hydroperoxyl radical in an aqueous solution is formed in reaction to Phase 02 during the regeneration of the catalyst. This leads to a reduction of ferric ions to ferrous ions and forming oxygen gas and acidifying medium (Equation 13) (Morais and Brito, 2016).

$$
\mathrm{Fe}^{3+}+\mathrm{HO}_{2}^{\cdot} \rightarrow \mathrm{Fe}^{2+}+\mathrm{O}_{2}+\mathrm{H}^{+} \quad \mathrm{K}=0.33-2.1 \times 10^{6} \mathrm{~L} \mathrm{~mol}^{-1} \mathrm{~s}^{-1}
$$

According to Frade (2013), the hydroperoxyl radical still undergoes decomposition and generates a superoxide radical $\left(\mathrm{O}_{2}{ }^{-}\right)$, since it is involved in the reduction cycle between $\mathrm{Fe}^{+2}$ and $\mathrm{Fe}^{+3}$. It also leads to an increase of concentration of $\mathrm{O}_{2}$ in treated wastewater (Equations 12, 14 and 15).

$$
\begin{array}{ll}
\mathrm{HO}_{2}^{\bullet} \rightarrow\left(\mathrm{O}_{2}^{\bullet-}\right)+\mathrm{H}^{+} & \mathrm{K}=1.58 \times 10^{5} \mathrm{~L} \mathrm{~mol}^{-1} \mathrm{~s}^{-1} \\
\mathrm{Fe}^{2+}+\mathrm{O}_{2}^{\bullet-} \rightarrow \mathrm{Fe}^{3+}+\mathrm{O}_{2}^{-2} & \mathrm{~K}=1 \times 10^{7} \mathrm{~L} \mathrm{~mol}^{-1} \mathrm{~s}^{-1} \\
\mathrm{Fe}^{3+}+\left(\mathrm{O}_{2}^{\circ-}\right) \rightarrow \mathrm{Fe}^{2+}+\mathrm{O}_{2} & \mathrm{~K}=5 \times 10^{7} \mathrm{~L} \mathrm{~mol}^{-1} \mathrm{~s}^{-1}
\end{array}
$$

In addition, residual hydrogen peroxide releases water and oxygen gas during its decomposition, and thus increases the DO concentration in treated effluent. It is worth noting that the decrease of the concentration of organic matter and the aeration in the jar test can also assist in increasing the dissolved oxygen.

After treatment by slow filtration, there was a reduction in the DO value and the final value was $3.22 \mathrm{mg} \mathrm{L}^{-1}$ at the end of the integration of the technologies, which included the following: physical absorption in the non-woven synthetic blanket, adsorption of chemicals in the sand layers and biological processes. For instance, dissolved organic material may be trapped in the filter that is adsorbed and metabolized by microorganisms. All these phenomena may affect the variation of the DO values (Arantes et al., 2014).

In the case of the phenolic compounds, crude laboratory effluent showed a high concentration of $84.83 \mathrm{mg} \mathrm{L}^{-1}$, during combined treatments. It showed a $94.12 \%$ reduction with a final value of $4.98 \mathrm{mg} \mathrm{L}^{-1}$, despite the fact that high reduction treated effluent is not suitable for the release standards established by Brazilian legislation of 2011. This has a maximum concentration of $0.5 \mathrm{mg} \mathrm{L}^{-1}$ of total phenols as a standard for the discharge of effluent, and requires other technologies to provide guidelines for the phenols.

\section{IPABH}

Rev. Ambient. Água vol. 13 n. 5, e2243 - Taubaté 2018 
The oils and greases parameter was determined for the crude laboratory effluent after the three treatment technologies had been combined, namely i): coagulation/flocculation; ii) the Fenton reaction; and iii) slow filtration resulting in a reduction of $99.10 \%$, which is a significant value in percentage terms. The values fell from $134.60 \mathrm{mg} \mathrm{L}^{-1}$ in crude laboratory effluent to $1.20 \mathrm{mg} \mathrm{L}^{-1}$ in post-filtration effluent during 400 minutes of treatment. The final result of $1.20 \mathrm{mg} \mathrm{L}^{-1}$ is a much lower value than the established threshold in Brazilian Resolution 2011 (Conama, 2011) for mineral oils up to $20 \mathrm{mg} \mathrm{L}^{-1}$ and $50 \mathrm{mg} \mathrm{L}^{-1}$ for vegetable oils and animal fats.

In the analysis of total organic carbon, the crude laboratory effluent showed a total organic carbon (TOC) value of $56.42 \mathrm{mg} \mathrm{L}^{-1}$ after combined treatments, a reduction of $87.54 \%$ with a final value of $7.02 \mathrm{mg} \mathrm{L}^{-1}$. The results showed that combined processes are efficient, not only in degrading organic compounds, but also perhaps in the degradation that is continued until a complete mineralization.

When the COD value (1400.49 $\mathrm{mg} \mathrm{O}_{2} \mathrm{~L}^{-1}$ ) and TOC value (56.42 $\mathrm{mg} \mathrm{L}^{-1}$ ) were calculated for crude laboratory effluent, the value obtained in TOC / COD ratio was 0.04. After treatment, COD and TOC values reached $346.21 \mathrm{mg} \mathrm{O}_{2} \mathrm{~L}^{-1}$ and $7.02 \mathrm{mg} \mathrm{L}^{-1}$ respectively. The TOC/COD ratio fell to 0.02 , which is indicative of the destruction of heteroatomic groups and unsaturations (Aquino et al., 2006; Morais and Brito, 2015; 2016).

In an analysis of the solids series for this type of effluent, there are no settleable solids and the most significant results are a $54.73 \%$ increase over total fixed solids treatment. This increase over total fixed solids treatment represents an estimate of inorganic matter, an interesting fact that shows the mineralization of organic compounds in $\mathrm{CO}_{2}, \mathrm{H}_{2} \mathrm{O}$ and inorganic ions. In the analysis of total volatile solids that represent an estimate of organic matter, there was an overall reduction of 74.49\%, a result that can be regarded as significant (Munoz et al., 2012).

\subsection{Reuse of wastewater for non-potable purposes.}

The criteria and guidelines used to determine the possibility of reusing treated liquid effluents, were based on publications from government agencies such as ABNT (1997) and USEPA (2012), as well as from Oenning Junior and Pawlowsky (2007); Tonetti et al., (2012); and Da Silva and Santana (2014).

In this article, a study was carried out of two guidelines mentioned previously and a summary was made of the limit values of the main analytical parameters, that included the feasibility of reuse for non-potable purposes.

The parameters studied for this purpose were as follows: $\mathrm{pH}$, total iron, COD, dissolved oxygen, turbidity, Total Organic Carbon (TOC) and oils and greases.

The analytical parameters $\mathrm{pH}$ (6.73), total iron $\left(0.56 \mathrm{mg} \mathrm{L}^{-1}\right)$, dissolved oxygen (DO $\left.3.22 \mathrm{mg} \mathrm{L}^{-1}\right)$, turbidity (0.78 NTU) and total organic carbon $\left(7.02 \mathrm{mg} \mathrm{L}^{-1}\right)$ are below the thresholds set by the guidelines with regard to reuse for non-potable purposes.

The values for reuse (non-potable purposes) are:

- $\mathrm{pH}$ value 6-9

- Total iron $\leq 5.00 \mathrm{mg} \mathrm{L}^{-1}$

$-\mathrm{DO} \geq 2.00 \mathrm{mg} \mathrm{L}^{-1}$

- Turbidity $\leq 30 \mathrm{NTU}$

- $\mathrm{TOC} \leq 10.00 \mathrm{mg} \mathrm{L}^{-1}$

However, the COD analyses (346.21 $\left.\mathrm{mg} \mathrm{O}_{2} \mathrm{~L}^{-1}\right)$ and oils and greases $\left(1.20 \mathrm{mg} \mathrm{L}^{-1}\right)$ did not reach the thresholds set by the cited guidelines. 
The values for reuse (non-potable purposes) are:

$-\mathrm{COD} \leq 90.00 \mathrm{mg} \mathrm{O}_{2} \mathrm{~L}^{-1}$

- Oils and greases $\leq 0.05 \mathrm{mg} \mathrm{L}^{-1}$

When adopting an approach using only Brazilian legislation (ABNT, 1997), DO, Oils and greases, settleable solids and $\mathrm{pH}$ values were included in Class A for reuse for surface water recharge (the dam designed for public supply, or for rivers up to $10 \mathrm{~km}$ upstream of this dam, regardless of the distance from the catchment point and reservoir volume).

\section{CONCLUSION}

The optimum concentrations of anionic polymer, $\mathrm{Fe}^{+2}, \mathrm{H}_{2} \mathrm{O}_{2}$ and $\mathrm{pH}$ values were obtained during a treatment that integrated coagulation/flocculation with the Fenton treatment followed by slow filtration. They had the following values: Coagulation/Flocculation (total iron= $82.49 \mathrm{mg} \mathrm{L}^{-1}$, anionic polymer $=0.80 \mathrm{mg} \mathrm{L}^{-1}$ and $\mathrm{pH}=6.00$ ), Fenton reagent (total iron $=13.00 \mathrm{mg} \mathrm{L}^{-1}, \mathrm{H}_{2} \mathrm{O}_{2}=200.00 \mathrm{mg} \mathrm{L}^{-1}$ and $\mathrm{pH}=3.00$ ) and slow filtration $(\mathrm{pH}=7.00$ and filtration rate $3 \mathrm{~m}^{3} \mathrm{~m}^{-2} \cdot \mathrm{d}^{-1}$ ).

The coagulation/flocculation/Fenton reagent followed by slow filtration showed the main final removals: $75.27 \%$ COD removal with a final value of $346.21 \mathrm{mgO}_{2} \mathrm{~L}^{-1} ; 83.50 \%$ absorbance removal $(200 \mathrm{~nm})$ displaying a final value of $0.94 ; 86.25 \%$ absorbance removal $(320 \mathrm{~nm})$ with a final value of 0.22 and $99.41 \%$ turbidity removal with final turbidity of 0.78 NTU. The total treatment time was 400 minutes.

The levels of total organic carbon (TOC) in treated effluent were evaluated by assessing the efficiency of the organic matter removal. The effluent treated at the end of the integration showed a reduction of $87.54 \%$ with a final value of $7.02 \mathrm{mg} \mathrm{L}^{-1}$; it can thus be concluded that combined treatments are efficient in the removal of organic compounds and can lead to degradation in the form of a complete mineralization.

The possibility of reuse for non-potable purposes of laboratory effluent when the obtained results are compared is established through values based on a set of guidelines. It can be concluded that treated effluent is not feasible for reuse, since it is necessary to increase the efficiency of the treatment by conducting more stages of treatment or improving the studied technologies, as well as monitoring other analytical parameters.

\section{ACKNOWLEDGEMENTS}

The authors would like to thank CAPES for the scholarship granted to Master's Degree student Chrystopher Allan Miranda Pereira.

\section{BIBLIOGRAPHICAL REFERENCES}

AGÊNCIA GOIANA DE REGULAÇÃO, CONTROLE E FISCALIZAÇÃO DE SERVIÇOS PÚBLICOS - AGR. Resolução n ${ }^{\circ}$ 68/2009. Dispõe sobre o Regulamento dos Serviços de Abastecimento de Água e de Esgotamento Sanitário da empresa de Saneamento de Goiás S/A. Diário Oficial [de] Goiás, n. 20601, 24 abr. 2009.

AMERICAN PUBLIC HEALTH ASSOCIATION - APHA. Standard Methods for the Examination of Water and Wastewater. 20. ed. New YorK, 1998. 
AQUINO, S. F.; SILVA, S. Q.; CHERNICHARO, C. A. Considerações práticas sobre o teste de demanda química de oxigênio (DQO) aplicado à análise de efluentes anaeróbios. Revista de Engenharia Sanitária Ambiental, v. 11, n. 4, p. 295-304, 2006.

ARANTES, C. C.; RIBEIRO, T. A. P.; PATERNIANI, J. E. S.; SLUSSAREK, M.; SILVA, G. K. E. Uso de coagulantes naturais à base de moringa oleífera e tanino como auxiliadores da filtração em mantas sintética não tecidas. Engenharia Agrícola, v. 34, p.780-788, 2014.

ASHRAFI, M.; CHAMJANGALI, M. A.; BAGHERIAN, G.; GOUDARZI, N. Application of linear and non-linear methods for modeling removal efficiency of textile dyes from aqueous solutions using magnetic $\mathrm{Fe}_{3} \mathrm{O}_{4}$ impregnated onto walnut shell. Spectrochimica Acta Part A: Molecular and Biomolecular Spectroscopy, v. 171, p. 268-279, 2017. https://doi.org/10.1016/j.saa.2016.07.049

ASSOCIAÇÃO BRASILEIRA DA INDÚSTRIA DE HIGIENE PESSOAL, PERFUMARIA E COSMÉTICOS - ABIHPEC. Panorama do setor de HPPC. 2016, disponível em: https://goo.gl/csg5Nt. Acesso em: 20 mar. 2017.

ASSOCIAÇÃO BRASILEIRA DE NORMAS TÉCNICAS - ABNT. Nbr 13969: tanques sépticos - unidade de tratamento complementar e disposição dos efluentes líquidos projeto, construção e operação. Rio de Janeiro, 1997.

BABUPONNUSAMI, A.; MUTHUKUMAR, K. A review on Fenton and improvements to the Fenton process for wastewater treatment. Journal of Environmental Chemical Engineering, v. 2, p. 557-572, 2014. https://doi.org/10.1016/j.jece.2013.10.011

BANERJEE, P.; DEY, S. S.; SWARNAKAR, S.; MUKHOPADHYAY, A.; GHOSH, S. Treatment of cosmetic effluent in different configurations of ceramic UF membrane based bioreactor: Toxicity evaluation of the untreated and treated wastewater using catfish (Heteropneustes fossilis). Chemosphere, v. 146, p. 133-144, 2016. https://doi.org/10.1016/j.chemosphere.2015.12.004

BAGUNDOL, T. B.; AWA, A. L.; ENGUITO, M. R. Efficiency of slow sand filter in purifying well water. Journal Multidisciplinary Studies, v. 2, n. 1, 2013.

BRITO, N. N.; PATERNIANI, J. E. S.; BROTA, G. A.; PELEGRINI, R. T. Ammonia removal from leachate by photochemical process using $\mathrm{H}_{2} \mathrm{O}_{2}$. Revista Ambiente \& Água, v. 5, p. 51-60, 2010.

BRITO, N. N.; LEITE, A. G. C.; CRUZ, T. M. G. S.; LIMA, T. C. R.; BORGES, F. A. Remediação de corante dispersivo utilizando tecnologia de tratamento: Fotoquímica $\mathrm{H}_{2} \mathrm{O}_{2}$ /Vis. Química Têxtil, v. 118, p. 36-52, 2015.

CAVALCANTE, A. M. Técnicas oxidativas para a remoção de matéria orgânica de uma corrente de soda exausta de refinaria de petróleo. 2005. 145p. Dissertação (Mestrado) - Universidade Federal do Rio de Janeiro, Rio de Janeiro, 2005.

CONSELHO NACIONAL DO MEIO AMBIENTE - CONAMA. Resolução nº 357, de 17 de março de 2005. Dispõe sobre a classificação dos corpos de água e diretrizes ambientais para o seu enquadramento, bem como estabelece as condições e padrões de lançamento de efluentes, e dá outras providências. Diário Oficial [da] União, n. 53, p. 58-63, 18 mar. 2005. 
CONSELHO NACIONAL DO MEIO AMBIENTE - CONAMA. Resolução nº 430, de 13 de maio de 2011. Dispõe sobre as condições e padrões de lançamento de efluentes, complementa e altera a Resolução n ${ }^{\circ}$ 357, de 17 de março de 2005, do Conselho Nacional do Meio Ambiente - CONAMA. Diário Oficial [da] União, n. 92, p. 89, 16 maio 2011.

DA SILVA, M. A.; SANTANA, C. G. Reuso de água: Possibilidades de redução do desperdício nas atividades domésticas. Periódico do centro de estudos em desenvolvimento sustentável da UNDB, n. 1, p. 1-14, 2014.

DURIGAN, M. A. B.; VAZ, S. R.; PERALTA-ZAMORA, P. Degradação de poluentes emergentes por processo Fenton e Foto Fenton. Química Nova, v. 35, n. 7, p. 1381-1387, 2012.

FRADE, V. M. F. Oxidação química de enrofloxacina pelo processo Fenton. 2013. 193p. Dissertação (Mestrado em Tecnologia Químico-Farmacêutica) - Faculdade de Ciências Farmacêuticas, Universidade de São Paulo, São Paulo, 2013. http://dx.doi.org/10.11606/D.9.2013.tde-27032014-162133

GAMA, M. R. Processos Fenton como Alternativa na Remoção de Interferentes Endócrinos e outros Micropoluentes Ambientais. Revista Virtual de Química, v. 4, n. 6, p. 777-787, 2012. http://dx.doi.org/10.5935/1984-6835.20120056

GIANNAKIS, S.; LÓPEZ, S. M. I. P.; SPUHLER, D.; PÉREZ, J. A. S.; IBÁNEZ, P. F.; PULGARIN, C. Solar disinfection is an augmentable, in situ-generated photo-Fenton reaction-Part 1: A review of the mechanisms and the fundamental aspects of the process. Applied Catalysis B: Environmentalv. 199, p. 199-223, 2016. https://doi.org/10.1016/j.apcatb.2016.06.009

GUO, J. S.; ABBAS, A. A.; CHEN, Y.P.; LIU, Z. P.; FANG, F.; CHEN, P. Treatment of landfill leachate using a combined stripping, Fenton, SBR, and coagulation process. Journal of $\begin{array}{lllll}\text { Hazardous } & \text { Materials, } & \text { v. }\end{array}$ https://doi.org/10.1016/j.jhazmat.2010.01.144

HU, Y.; WANG, X. Application of surrogate parameters in characteristic UV-vis absorption bands for rapid analysis of water contaminants. Sensors and Actuators B: Chemical, v. 239, p. 718-726, 2017. https://doi.org/10.1016/j.snb.2016.08.072

KHANDARE, R. V.; GOVINDWAR, S. P. Phytoremediation of textile dyes and effluents: Current scenario and future prospects. Biotechnology Advances, v. 33, p. 1697-1714, 2015. https://doi.org/10.1016/j.biotechadv.2015.09.003

LIN, M.; NING, X.; AN, T.; ZHANG, J.; CHEN, C.; KE, Y. et al. Degradation of polycyclic aromatic hydrocarbons (PAHs) in textile dyeing sludge with ultrasound and Fenton processes: Effect of system parameters and synergistic effect study. Journal of $\begin{array}{llllll}\text { Hazardous } & \text { Materials, } & \text { v. } & \text { 307, } & \text { p. } & 7-16,\end{array}$ https://doi.org/10.1016/j.jhazmat.2015.12.047

MA, X. J.; XIA, H. L. Treatment of water-based printing ink wastewater by Fenton process combined with coagulation. Journal of Hazardous Materials, v. 162, p. 386-390, 2009. https://doi.org/10.1016/j.jhazmat.2008.05.068

MARCIONILIO, S. M. L. O.; BARROS, V. S; LÉON, J. J. L. Avaliação da coagulação química e eletrocoagulação no tratamento de efluente de polo farmacêutico. RQI- Revista Química Industrial, n. 749, p. 22-31, 2015. 
MIRZAEI, A.; CHEN, Z.; HAGHIGHT, F.; YERUSHALMI, L. Removal of pharmaceuticals from water by homo/heterogeneous Fenton-type processes - A review. Chemosphere, v. 174, p. 665-688, 2017. https://doi.org/10.1016/j.chemosphere.2017.02.019

MORAIS, W. O.; BRITO, N. N. Tratamento de efluente de indústria cosmética via reagente de Fenton. Revista de Química Industrial, v. 84, n. 753, p.52-68, 2016.

MORAIS, W. O.; BRITO, N. N. Treatment of simulated wastewater via Fenton reaction at a production line of sunscreen. Oxidation Communications, v. 38, n. 4A, p. 2261-2272, 2015.

MUNOZ, M.; PEDRO, Z. M.; PLIEGO, G.; CASAS, J. A.; RODRIGUEZ, J. J. Chlorinated byproducts from the Fenton-like oxidation of polychlorinated phenols. Industrial e Engineering Chemistry Research, v. 51, p. 13092-13099, 2012. http:dx.doi.org/10.1021/ie3013105

NASCIMENTO, A. P.; PELEGRINI, R. T.; BRITO, N. N. Filtração Lenta para o tratamento de águas para pequenas comunidades rurais. Revista Eletrônica de Engenharia Civil, v. 2, p. 54-58, 2012. https://doi.org/10.5216/reec.v4i2.19705

NOGUEIRA, R. F. P.; TROVÓ, A. G.; SILVA, M. R. A.; VILLA, R. D. Fundamentos e aplicações ambientais dos processos Fenton e foto-Fenton. Química Nova, v. 30, n. 2, p. 400-08, 2007. http://dx.doi.org/10.1590/S0100-40422007000200030

OENNING JUNIOR, A.; PAWLOWSKY, U. Avaliação de tecnologias avançadas para o reuso de águas em indústria metal-mecânica. Engenharia Sanitária e Ambiental, v. 12, n. 3, p. 305-316, 2007. https://doi.org/10.1590/S1413-41522007000300010

OLIVEIRA, M. C.; NOGUEIRA, R. F. P.; GOMES NETO, J. A.; JARDIM, W. F.; ROHWEDDER, J. J. R. Sistema de injeção em fluxo espectrofotométrico para monitorar peróxido de hidrogênio em processo de fotodegradação por reação foto-fenton. Química Nova, v. 24, n. 2, p. 188-190, 2001. http://dx.doi.org/10.1590/S010040422001000200007

POMPEI, C. M. E.; CIRIC, L.; CANALES, M.; KARU, K.; VIEIRA, E. M.; CAMPOS, L. C. Influence of PPCPs on the performance of intermittently operated slow sand filters for household water purification. Science of The Total Environment, v. 581-582, p. 174185, 2017. https://doi.org/10.1016/j.scitotenv.2016.12.091

QUARTAROLI, L.; KURITZA, J. C.; CAVALLINI, G. S.; VIDAL, C. M. S.; SOUZA, J. B. Aplicação de polímeros aniônico e catiônico na flotação por ar dissolvido como forma de pós-tratamento de efluente de indústria de papel e celulose. Scientia Forestalis, v. 42, n. 101, p. 57-67, 2014.

RAGASSON, M. K. Aplicação do reagente Fenton no tratamento de lixiviado de aterros sanitários. Especialize, n. 4, 2013.

SALVADOR, T.; MARCOLINO, L. H.; PERALTA-ZAMORA, P. Degradação de corantes têxteis e remediação de resíduos de tingimento por processos Fenton, Foto Fenton e Eletro Fenton. Química Nova, v. 35, n. 5, p. 932-938, 2012.

SHAIKH, S. M. R.; NASSER, M. S.; HUSSEIN, I. A.; BENAMOR, A. Investigation of the effect of polyelectrolyte structure and type on the electrokinetics and flocculation behavior of bentonite dispersions. Chemical Engineering Journal, v. 311, p. 265-276, 2017. https://doi.org/10.1016/j.cej.2016.11.098 
SEMERARO, P.; RIZZI, V.; FINI, P.; MATERA, S.; COSMA, P.; FRANCO, E. et al. Interaction between industrial textile dyes and cyclodextrins. Dyes and Pigments, v. 119, p. 84-94, 2015. https://doi.org/10.1016/j.dyepig.2015.03.012

SOHRABI, M. R.; KHAVARAN, A.; SHARIATI, S.; SHARIATI, S. Removal of Carmoisine edible dye by Fenton and photo Fenton processes using Taguchi orthogonal array design. Arabian Journal of Chemistry, v. 10, p. S3523-S3531, 2017. https://doi.org/10.1016/j.arabjc.2014.02.019

TONETTI, A. L.; CORAUCCI FILHO, B.; NICOLAU, C. E.; BARBOSA, M.; TONON, D. Tratamento de esgoto e produção de água de reuso com o emprego de filtro lento. Engenharia Sanitária e Ambiental, v. 17, n. 3, p. 287-294, 2012.http://dx.doi.org/10.1590/S1413-41522012000300005

TORRADESA, F.; MONTAÑOB, J. G. Using central composite experimental design to optimize the degradation of real dye wastewater by Fenton and photo-Fenton reactions. Dyes and Pigments, v. 100, p. 184-189, 2014.

UNITED STATES. Environmental Protection Agency - USEPA. Guidelines for Water Reuse. EPA/600/R-12/618. Washington, DC, 2012. 450 p.

WIŚNIEWSKA, M.; CHIBOWSKI, S.; URBAN, T. Adsorption properties of the nanozirconia/anionic polyacrylamide system-Effects of surfactant presence, solution pH and polymer carboxyl groups content. Applied Surface Science, v. 370, p. 351-356, 2016. https://doi.org/10.1016/j.apsusc.2016.02.188 


\begin{tabular}{|} 
Ambiente \& Água - An Interdisciplinary Journal of Applied Science \\
ISSN 1980-993X - doi:10.4136/1980-993X \\
www.ambi-agua.net \\
E-mail: ambi.agua@gmail.com
\end{tabular}

\title{
Incêndios no Pantanal de Corumbá, MS: modelagem e previsão a partir das técnicas de análise multivariada
}

\author{
ARTICLES doi:10.4136/ambi-agua.2024
}

Received: 08 Oct. 2016; Accepted: 24 Jul. 2018

\author{
Hevelyne Henn da Gama Viganón ${ }^{1,2 *}$; Celso Correia de Souza ${ }^{1}$; \\ Marcia Ferreira Cristaldo ${ }^{1,3}$; José Francisco dos Reis Neto ${ }^{4}$; \\ Leandro de Jesus ${ }^{1,3}$
}
${ }^{1}$ Universidade para o Desenvolvimento do Estado e da Região do Pantanal (UNIDERP), Campo Grande, MS, Brasil Pós-Graduação em Meio Ambiente e Desenvolvimento Regional. E-mail: hevelyne.vigano@ifms.edu.br, csouza939@gmail.com, marcia.cristaldo@ifms.edu.br, leandro.jesus@ifms.edu.br
${ }^{2}$ Instituto Federal de Mato Grosso do Sul (IFMS), Campo Grande, MS, Brasil Departamento de Matemática e Estatística. E-mail: hevelyne.vigano@ifms.edu.br ${ }^{3}$ Instituto Federal de Mato Grosso do Sul (IFMS), Campo Grande, MS, Brasil
Departamento de Informática e Robótica.E-mail: marcia.cristaldo@ifms.edu.br, leandro.jesus@ifms.edu.br ${ }^{4}$ Universidade para o Desenvolvimento do Estado e da Região do Pantanal (UNIDERP), Campo Grande, MS, Brasil Pós-Graduação em Produção e Gestão Agroindustrial (UNIDERP). E-mail: jfreisneto@gmail.com
${ }^{*}$ Corresponding author

\section{RESUMO}

Os incêndios e as queimadas que ocorrem no Pantanal causam grandes prejuízos à fauna e flora locais. A previsão de eventos é de grande importância por possibilitar que as catástrofes nesse ecossistema sejam amenizadas ou, até mesmo evitadas. Este estudo teve como objetivo avaliar as ocorrências de queimadas e incêndios no Pantanal Sul-Mato-Grossense, associadas às variáveis meteorológicas e realizar uma modelagem de previsão a partir de técnicas de análise multivariada de dados. As variáveis ambientais envolvidas nesse processo foram extraídas da base de dados do Centro de Previsão de Tempo e Estudos Climáticos do Instituto Nacional de Pesquisas Espaciais (INPE) e do banco de dados meteorológicos para ensino e pesquisa do Instituto Nacional de Meteorologia (INMET). Foram observadas que a temperatura, umidade relativa e radiação solar, possuem um relacionamento estreito com a ocorrência dos focos e as correlações resultantes foram satisfatórias para a aplicação das modelagens de previsão. A técnica de Regressão Linear Múltipla apresentou $41 \%$ de ajustamento e a técnica de Análise Auto-regressiva Integrada de Médias Móveis apresentou ajustamento de 66,5\% e desempenho geral de 68,4\%, tornando-a a metodologia mais recomendada para a previsão.

Palavras-chave: bioma pantaneiro, perfil climatológico, previsão de fogo.

\section{Fires in the Pantanal: modeling and forecasting using multivariate analysis techniques}

\section{ABSTRACT}

The occurrence of fires in Pantanal causes great damage to the local fauna and flora. Predicting these events is of great importance, enabling catastrophes in this ecosystem to be mitigated or even avoided. This study evaluated the occurrence of fires in Southern Pantanal 
associated with meteorological variables and created a predictive model using multivariate data analysis techniques. The environmental variables involved in this process were extracted from the database of the Center for Weather Forecasting and Climatic Studies of the National Institute of Space Research (INPE) and the meteorological database for teaching and research of the National Institute of Meteorology (INMET). It was observed that temperature, relative humidity and solar radiation have a close relationship with the occurrence of fires and the resulting correlations were considered satisfactory for the application of forecasting models. The Multiple Linear Regression technique presented an adjustment of $41 \%$ and the Integrated Averaging Analysis of Moving Averages presented an adjustment of $66.5 \%$ and a general performance of $68.4 \%$, making it the most-recommended forecasting methodology.

Keywords: biome pantaneiro, climatological profile, fire forecast.

\section{INTRODUÇÃO}

A ocorrência de incêndios no Pantanal Sul-Mato-Grossense representa uma ameaça para a conservação da biodiversidade local, com influência nas condições climáticas desse importante bioma, causando sérias consequências à manutenção de processos ecológicos, com reflexos inclusive na permanência do homem nesse habitat natural (Nogueira e Santos, 2015).

Em grande parte as queimadas e incêndios ocorrem por causas antrópicas (Trejo, 2008; Santos e Nogueira, 2015; White e White, 2016; Clemente et al., 2017). Na estação de estiagem encontram condições propícias a se propagarem em alta magnitude pois, os fatores climáticos e meteorológicos, tais como elevadas temperaturas, radiação solar, baixa umidade relativa do ar e vento, potencializam a sua ocorrência, visto que, o ar mais seco aumenta a evapotranspiração dos vegetais e favorece maior atuação da radiação solar sobre a superfície terrestre que, por sua vez, eleva a temperatura do ar, criando um ambiente facilmente propício ao processo de combustão (Deppe et al., 2004; Magi et al., 2012; Gonçalves e Vieira, 2013; Almeida et al., 2016).

Os danos decorrentes dos processos de queimadas e incêndios nos diversos componentes do bioma são: i) na vegetação ocorrem perdas de espécies nativas; ii) no solo ocorrem a destruição da camada orgânica, a sua exposição e o enfraquecimento; mudanças nas propriedades físicas (porosidade e penetrabilidade da água); deslizamentos e erosão; iii) na fauna ocorrem mortes dos animais, destruição de ninhos e modificação do habitat (animais migram por busca de alimentos e abrigo); iv) nas propriedades ocorrem destruição de casas, construções, veículos, maquinários e equipamentos diversos; v) na vida humana ocorrem problemas respiratórios decorrentes da poluição atmosférica , acidentes em estradas causados pela fumaça, e morte de pessoas envolvidas no combate ao fogo (Freitas et al., 2005; Pereira et al., 2012; Soares et al., 2009; Silva, 2014; Nunes et al., 2015).

A concentração de queimadas e incêndios ocorre entre os meses de julho a novembro, no bioma pantaneiro do Estado de Mato Grosso do Sul, também denominado de período JASON, caracterizado pela estação seca, onde os elementos climáticos contribuem fortemente com o processo de combustão da vegetação, registrando maior incidência no município de Corumbá (Viganó et al., 2017).

Estudos sobre a composição elementar das partículas de aerossol resultantes dessas queimadas mostram que a emissão de carbono grafítico (Black-carbon) durante a estação seca associada a elementos conhecidos como traçadores de emissões de queimadas, Enxofre (S), Potássio (K), Cloro (Cl), Cálcio (Ca) e Zinco (Zn), potencializam a ocorrência das queimadas e consequentemente o efeito estufa (Nogueira e Santos, 2015; Artaxo et al., 2006).

Diante da constatação dos grandes prejuízos causados pelo processo de combustão no bioma pantaneiro, a previsão, o controle e a fiscalização desses eventos são de considerável 
interesse às autoridades competentes e ao homem pantaneiro. E nessa perspectiva, determinar e prever a localização dos focos, os riscos e as ocorrências, representa um desafio para a elaboração de planos de conservação ou de manejo.

Segundo Silva (2014) e Morrison (2014), o meio mais eficiente e de baixo custo em países de grande extensão territorial, como o Brasil, é o monitoramento de queimadas e incêndios por meio de imagens orbitais de satélites pelo processo de sensoriamento remoto, que permite detectar e localizar os focos em tempo real. Outras ferramentas que podem ser utilizadas para a previsão de focos de queimadas são as técnicas de análise multivariada de séries temporais, através das quais, a partir de uma massa de dados sobre os valores de algumas variáveis meteorológicas que influenciam a ocorrência de queimadas e do seu número de focos, é possível obter uma previsão de ocorrência do fenômeno.

Desse modo, o objetivo deste trabalho foi utilizar conceitos de análise de regressão linear múltipla e de médias móveis autorregressivas integradas para determinar uma modelagem matemática de previsão sobre o número de focos de incêndios no bioma do Pantanal de Corumbá, levando-se em conta os níveis de medidas de uma série de variáveis meteorológicas, como preditoras e avaliar a correlação existente entre a ocorrência desses focos com essas variáveis meteorológicas.

\section{MATERIAIS E MÉTODOS}

\section{1. Área de Estudo}

Localizada na bacia do Alto Paraguai, na região Centro-Oeste do Brasil, às margens do rio Paraguai e na fronteira com a Bolívia, Corumbá é a quarta maior cidade do Estado de Mato Grosso do Sul, com cerca de 104.000 habitantes, a primeira cidade do Estado em extensão territorial, com aproximadamente $65.000 \mathrm{~km}^{2}$, onde $95 \%$ do total de sua área é bioma Pantanal (IBGE, 2016). Dentre os nove municípios que constituem o Pantanal Sul-Mato-Grossense, Corumbá representa $69 \%$ do bioma.

A localização geográfica de Corumbá está compreendida entre as coordenadas de 1900’32' ' S e 57³9'10' ' W e altitude de 118 m acima do nível do mar. A classificação climática de Corumbá, pertence ao tipo Aw (Clima Tropical Úmido Megatérmico), ou seja, clima Tropical de Altitude, com verões quentes e chuvosos, e inverno seco (Brasil, 1982).

De acordo com a Secretaria do Estado de Meio Ambiente e Desenvolvimento Econômico de Mato Grosso do Sul (SEMADE), e com a caracterização da cidade no RADAMBRASIL, o município de Corumbá divide-se em três regiões geomorfológicas: Região do Pantanal MatoGrossense; Região da Depressão do Alto Paraguai e Região da Bodoquena e Morrarias do Urucum-Amolar.

A cobertura vegetal predominante é o Cerrado típico do Pantanal, Cerrado Parque e Cerrado Arbóreo Aberto. Nos locais mais elevados, há áreas de matas e, ao sul do município, ocorre vegetação chaquenha; nas áreas mais baixas, encontram-se as palmeiras carandá e o paratudal, que trata de formação savânica alagável (Brasil, 1982; IBGE, 2016).

\subsection{Coleta de dados}

As informações das variáveis climatológicas e meteorológicas analisadas foram extraídas do (1) sistema de informações geográficas do banco de dados meteorológicos para ensino e pesquisa do Instituto Nacional de Meteorologia (INMET), utilizando a estação de coleta 83552 (1900'36' 'S e 57³8'60', W), e (2) do banco de dados da plataforma de coleta 31949 (1901'19.2'’ S e 57³9'7.2', W), disponível no Centro de Previsão de Tempo e Estudos Climáticos do Instituto Nacional de Pesquisas Espaciais (CPTEC- INPE) numa série temporal de 2005 a 2015.

Foram utilizadas 24 medidas diárias das variáveis preditoras (disponíveis de hora em hora

\section{IPABH}

Rev. Ambient. Água vol. 13 n. 5, e2024 - Taubaté 2018 
das 00h00 às 24h00) de cada variável meteorológica (total de 18 diferentes variáveis testadas), constituindo uma massa de dados inicial de 1.710.720 registros para toda a série temporal de janeiro a dezembro de 2005 a 2015. Para o período de julho a novembro (JASON), utilizaramse 712.800 registros na mesma série de medidas meteorológicas que foram tratadas para as modelagens. A base de dados da contagem dos focos, foi constituída apenas pelo total diário de focos detectados nos horários da passagem do satélite de referência, o que significa que essa contagem corresponde apenas à uma fração do total dos focos ocorridos, por este estudo se tratar da aplicação de técnicas de análise multivariada. Para a análise das variáveis meteorológicas do município, foram ainda calculados valores médios diários (série de 11 anos de dados), que foram calculadas a partir das médias compensadas diárias de cada variável, dada por $\mathrm{X}=\left(2 . \mathrm{X}_{00}+\mathrm{X}_{12}+\mathrm{X}_{\text {máx }}+\mathrm{X}_{\text {mín }}\right)$, onde $\mathrm{X}$ representa a variável em análise; $\mathrm{x}_{00}$ e $\mathrm{X}_{12}$ são os valores da variável em análise observadas à $00 \mathrm{~h} 00$ e às $12 \mathrm{~h} 00$ do tempo médio de Greenwich (TMG) e; os valores extremos $x_{\text {máx }}$ e $x_{\text {mín }}$ são os valores dos registros máximo e mínimo dentro do intervalo de $24 \mathrm{~h} 00$ de cada variável.

Com isso, a base de dados já tratada com as descrições acima, foi configurada com os dados médios compensados diários das variáveis meteorológicas (variáveis independentes) e com os quantitativos totais de referência diários dos focos (variável dependente), ou seja, cerca de 1650 dias avaliados.

Os dados da variável ambiental, número de focos, foram obtidos da Divisão de Geração de Imagens (DGI) do Instituto Nacional de Pesquisas Espaciais (INPE), que recebe e processa as imagens dos satélites de referência da série National Oceanic Atmospheric Administration NOAA-12 (de 2005 a 2007) e da National Aeronautics and Space Administration - NASA AQUA M-T (de 2008 a 2015), por meio, respectivamente, dos sensores Advanced Very High Resolution Radiometer - AVHRR e Moderate Resolution Imaging Spectroradiometer MODIS, cujas informações mantêm o mesmo padrão de amostragem temporal e de detecção, possuem horário de passagem em um mesmo ponto da Terra estável ao longo dos anos e são considerados isentos de falsas detecções em decorrência de reflexos do Sol na superfície terrestre. Cabe salientar que foram utilizadas medidas diárias disponíveis dos dados dos focos detectados pelos satélites de referência para a aplicação dos métodos multivariados de previsão de séries temporais, por apresentarem menores coeficientes de variação.

As variáveis meteorológicas selecionadas para o estudo da análise de correlação com o número de Focos $(\mathrm{N})$ foram: Temperatura Instantânea do $\operatorname{Ar}(\mathrm{oC})\left(\mathrm{T}_{\mathrm{Ar}}\right)$;Temperatura Máxima do $\operatorname{Ar}(\mathrm{oC})$ ( $\mathrm{T}_{\mathrm{Max}}$ ); Temperatura Mínima do $\operatorname{Ar}(\mathrm{oC})$ ( $\mathrm{T}_{\mathrm{Min}}$ ); Temperatura do Solo (oC) a

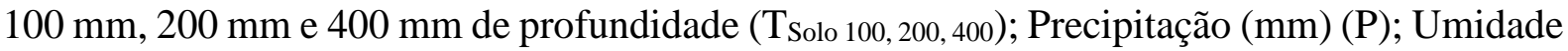
Relativa (\%) (URel); Umidade Absoluta (\%) (U $\left.\mathrm{U}_{\mathrm{Abs}}\right)$; Velocidade do Vento (m/s) a 10 metros (V Vento); Direção do Vento Máximo (oNV) (DMax); Direção do Vento (oNV) (D); Pressão Atmosférica (mB) ( $\left.\mathrm{P}_{\text {Atm }}\right)$; Radiação Solar Acumulada (MJ m-3) (Rsolar); Contagem de Água no Solo (m3) 100 mm, 200 mm e 400 mm de profundidade (Csolo 100, 200, 400).

\subsection{Técnicas de Análise Multivariadas para as previsões}

Para as modelagens das previsões dos focos foram utilizadas as técnicas de Regressão Linear Múltipla (RLM) e Análise Auto-Regressiva Integrada de Médias Móveis (ARIMA) (Hair Jr. et al., 2005; Morettin e Toloi, 2006; Caúla et al., 2016). Em ambos os modelos foram consideradas como variável dependente o número de focos e as variáveis meteorológicas como independentes. Os modelos foram testados com a série total de dados de janeiro de 2005 a dezembro de 2015 e, posteriormente, para o período de seca nos meses de julho a novembro com os dados das médias compensadas diárias das variáveis meteorológicas e as quantidades totais de referência de focos diários.

As técnicas foram executadas no software IBM-SPSS, sendo que, para o modelo RLM foi utilizada a configuração "stepwise”, com nível de significância de 5\%, e para o modelo ARIMA 
foi adotada a configuração "expert modeler”, com a previsão após o último caso em análise e até cinco passos adiante.

\subsection{Análises Estatísticas}

As análises estatísticas aplicadas aos modelos para os ajustes, a validação e o desempenho foram: a) Correlação de Pearson das variáveis independentes com relação a variável dependente; b) Análise de Variância (ANOVA) e estatística F; c) Significância (p-valor); d) R² e $\mathrm{R}^{2}$ ajustado; e) Teste de Durbin-Watson; f) Análise do Fator de Inflação da Variância; g) Análise dos Resíduos; h) Critério de Informação Bayesiano (BIC); i) Análise das funções de Autocorrelação dos Resíduos; j) Análise de Erros: raiz do erro quadrático médio (RMSE), erro percentual absoluto médio (MAPE) e erro absoluto médio (MAE) (Brito et al., 2016).

\section{RESULTADOS E DISCUSSÃO}

Foram detectados 27.902 focos nos meses de julho a novembro, no período de 2005 a 2015.A Tabela 1 apresenta a distribuição mensal dos focos, as médias mensais, os desvios padrão e os coeficientes de variação correspondentes, para a série analisada, ao longo dos meses de janeiro a dezembro, no período de 2005 a 2015, obtida de todos os sensores dos satélites que operam na faixa termal de $4 \mu \mathrm{m}$, sem sobreposição na leitura dos focos, para a varredura de 24 medidas horárias ao dia.

Tabela 1. Estatística mensal dos focos para os anos de 2005 a 2015, no bioma pantaneiro de Corumbá (MS).

\begin{tabular}{lccccccccccccc}
\hline & \multicolumn{10}{c}{ MÊS } \\
\cline { 2 - 5 } & JAN & FEV & MAR & ABR & MAI & JUN & JUL & AGO & SET & OUT & NOV & DEZ \\
\hline $\mathbf{2 0 0 5}$ & 3 & 45 & 22 & 37 & 134 & 224 & 535 & 2475 & 819 & 247 & 47 & 20 \\
$\mathbf{2 0 0 6}$ & 4 & 19 & 17 & 6 & 34 & 7 & 65 & 262 & 387 & 58 & 40 & 0 \\
$\mathbf{2 0 0 7}$ & 2 & 7 & 4 & 15 & 14 & 38 & 64 & 811 & 1443 & 205 & 32 & 5 \\
$\mathbf{2 0 0 8}$ & 8 & 3 & 12 & 14 & 5 & 3 & 27 & 166 & 889 & 252 & 24 & 157 \\
$\mathbf{2 0 0 9}$ & 161 & 88 & 45 & 219 & 859 & 255 & 265 & 591 & 855 & 662 & 331 & 36 \\
$\mathbf{2 0 1 0}$ & 13 & 38 & 62 & 67 & 34 & 61 & 332 & 646 & 773 & 288 & 174 & 221 \\
$\mathbf{2 0 1 1}$ & 52 & 13 & 1 & 1 & 11 & 18 & 43 & 80 & 258 & 98 & 344 & 492 \\
$\mathbf{2 0 1 2}$ & 154 & 59 & 75 & 38 & 118 & 76 & 469 & 2709 & 1792 & 522 & 53 & 86 \\
$\mathbf{2 0 1 3}$ & 93 & 33 & 92 & 28 & 36 & 4 & 75 & 254 & 460 & 207 & 259 & 105 \\
$\mathbf{2 0 1 4}$ & 94 & 64 & 16 & 49 & 12 & 17 & 24 & 58 & 191 & 271 & 111 & 16 \\
$\mathbf{2 0 1 5}$ & 77 & 41 & 11 & 20 & 30 & 188 & 152 & 708 & 781 & 341 & 200 & 290 \\
\hline Média & 60 & 37 & 32 & 45 & 117 & 81 & 186 & 796 & 786 & 286 & 147 & 130 \\
DP* & 59 & 26 & 30 & 59 & 239 & 91 & 189 & 884 & 509 & 231 & 116 & 147 \\
CV* & 98 & 70 & 94 & 131 & 204 & 112 & 102 & 111 & 65 & 81 & 79 & 113 \\
\hline
\end{tabular}

*DP: Desvio padrão; CV: Coeficiente de Variação (\%).

Observa-se, na Tabela 1, que as médias mensais no período de 2005 a 2015 crescem muito a partir do mês de julho, com picos em agosto e setembro, atingindo os seus valores médios máximos (796 focos e 786 focos, respectivamente). Os desvios padrão e, consequentemente, os coeficientes de variação têm valores altos, indicando uma grande heterogeneidade dos dados, o que é compreensível, pois, no primeiro semestre, acontecem poucos focos ao passo que no segundo semestre, estação seca, eles aumentam consideravelmente.

Com isso, o período selecionado para a aplicação das técnicas de previsão RLM e ARIMA, restringiu-se aos meses de julho, agosto, setembro, outubro e novembro de cada ano, denominado de período JASON, que corresponde aos meses em análises por se tratar de ser o 
período com a maior concentração de ocorrência de focos. Para a análise das séries temporais, foram utilizados os focos detectados apenas pelos satélites de referência NOAA-12 e NASA AQUA M-T, por apresentarem órbita polar, o que gera dados que podem ser analisados estatisticamente para as mesmas regiões ao longo dos anos com erros minimizados e efeitos atmosféricos corrigidos.

Para a execução da análise de regressão foi aplicada a transformação logarítmica de base 10 sobre os valores da variável número de focos $(\log (\mathrm{N}))$, para estabilizar a variância devido à grande variabilidade desses dados, pois, as previsões devem se caracterizar pela acurácia de seus resultados, pela simplicidade dos métodos empregados e pela confiabilidade estatística dos modelos empregados para gerar previsões.

A Tabela 2 mostra os resultados da correlação linear entre a variável $\log (\mathrm{N})$ e as variáveis meteorológicas preditoras.

Tabela 2. Correlação linear de Pearson (r) entre a variável Log $(\mathrm{N})$ e as variáveis meteorológicas preditoras, no período de 2005 a 2015, no município de Corumbá (MS).

\begin{tabular}{lclc}
\hline Variáveis & $\mathrm{r}$ & Variáveis & $\mathrm{r}$ \\
\hline $\mathrm{T}_{\text {Max }}\left({ }^{\circ} \mathrm{C}\right)$ & 0,383 & $\mathrm{C}_{\text {Solo100 }}(\mathrm{m} 3)$ & $-0,041$ \\
$\mathrm{~T}_{\text {Ar }}\left({ }^{\circ} \mathrm{C}\right)$ & 0,092 & $\mathrm{C}_{\text {Solo200 }}(\mathrm{m} 3)$ & $-0,144$ \\
$\mathrm{~T}_{\text {Min }}\left({ }^{\circ} \mathrm{C}\right)$ & 0,104 & $\mathrm{C}_{\text {Solo400 }}(\mathrm{m} 3)$ & $-0,038$ \\
$\mathrm{R}_{\text {Solar }}(\mathrm{MJ} \mathrm{m}-2)$ & 0,310 & $\mathrm{D}_{\text {Max }}(\mathrm{oNV})$ & $-0,080$ \\
$\mathrm{~T}_{\text {Solo100 }}\left({ }^{\circ} \mathrm{C}\right)$ & 0,183 & $\mathrm{D}(\mathrm{oNV})$ & $-0,090$ \\
$\mathrm{~T}_{\text {Solo200 }}\left({ }^{\circ} \mathrm{C}\right)$ & 0,165 & $\mathrm{P}(\mathrm{mm})$ & $-0,085$ \\
$\mathrm{~T}_{\text {Solot00 }}\left({ }^{\circ} \mathrm{C}\right)$ & 0,013 & $\mathrm{P}_{\text {Atm }}(\mathrm{mB})$ & $-0,019$ \\
$\mathrm{~V}_{\text {Vento10 }}\left(\mathrm{m} \mathrm{s}^{-1}\right)$ & 0,114 & $\mathrm{U}_{\text {Rel }}(\%)$ & $-0,564$ \\
$\mathrm{~V}_{\text {VentoMax }}\left(\mathrm{m} \mathrm{s}^{-1}\right)$ & 0,067 & $\mathrm{U}_{\text {Inst }}(\%)$ & 0,037 \\
\hline
\end{tabular}

Os valores negativos apresentados pelas correlações de Pearson (r) significam que, quanto menores os valores da variável preditora, maiores as chances de ocorrências de queimadas. Entretanto, se o valor de $\mathrm{r}$ for positivo, quanto maiores forem os valores das variáveis preditoras, maiores serão as chances de ocorrências de focos.

As variáveis meteorológicas que mais contribuem para a ocorrência de focos, de acordo com a análise de correlação para a aplicação dos métodos de RLM e ARIMA, são temperatura máxima, umidade relativa e radiação solar, as quais apresentaram os maiores valores absolutos de r. As demais variáveis preditivas que foram desconsideradas no modelo de regressão explicam o fenômeno em menos de $2 \%$, por se tratarem de termos indiretos, já associados com os fatores preditivos e apresentarem multicolinearidade com as demais variáveis.

Comparando os dados da Tabela 1 com os dados de Torres et al. (2011), sobre um estudo de ocorrência de incêndios em Juiz de Fora (MG), as correlações de Pearson mais significativas que se apresentaram mais próximas do presente trabalho foram as variáveis meteorológicas Radiação solar ( $r=0,357)$, Temperatura máxima $(r=0,182)$ e Umidade relativa $(r=-0,467)$, diferindo-se na temperatura pelas diferenças geográficas e climatológicas das duas regiões comparadas. Esse resultado, confirma a escolha das variáveis meteorológicas para as técnicas de modelagens aplicadas.

A variabilidade mensal para o período JASON para a série temporal de 2005 a 2015 do número de focos, da temperatura máxima, da umidade relativa e da radiação solar são apresentadas na Figura 1. É possível observar no gráfico da Figura 1 que a série que representa o número de focos (representado pelas barras) está disposta mensalmente, com cada barra correspondendo aos meses do período JASON (de julho a novembro). 


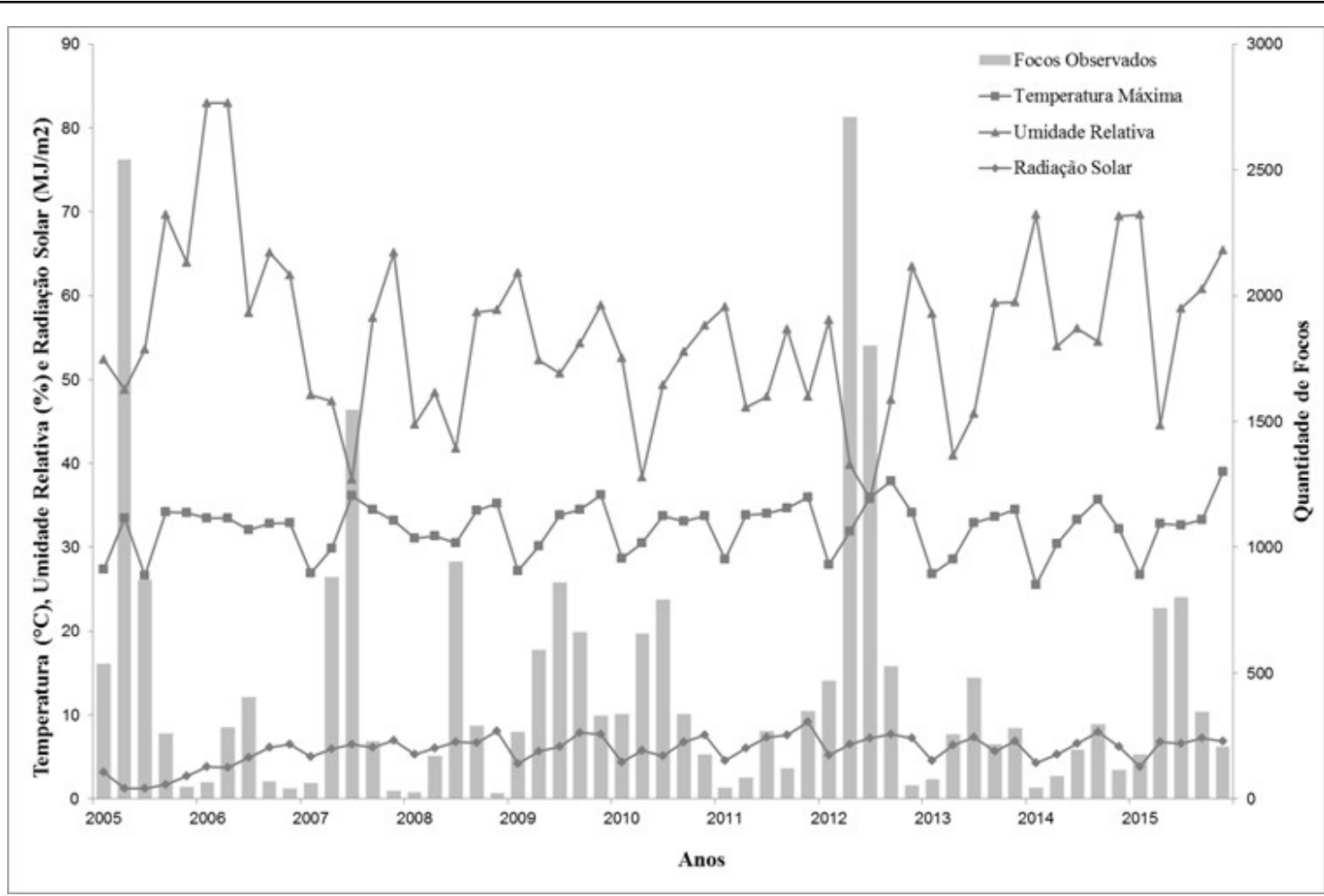

Figura 1. Variabilidade das médias mensais dos dados meteorológicos (Temperatura, Radiação e Umidade Relativa), relacionadas ao número total de focos para o período JASON da série temporal de 2005 a 2015, no município de Corumbá (MS).

Analisando o comportamento das variáveis meteorológicas com relação ao número de focos, verifica-se que, em geral, os maiores valores do número de focos ocorreram para os menores valores da umidade relativa, mostrando a correlação inversa entre essas duas variáveis como pode ser observado para o mês de setembro dos anos de 2007 e 2012. A baixa umidade relativa do ar influencia diretamente na vegetação, tornando-a mais seca, o que torna propício o aumento de material combustível e, consequentemente, a susceptibilidade ao processo de combustão. Os picos dos focos ocorreram para os meses de agosto e setembro do período de estiagem, com valor médio em torno de 450 focos.

A temperatura máxima média foi de $32,3^{\circ} \mathrm{C}$ e pode-se observar que para as temperaturas mais elevadas o número de focos é maior como, por exemplo, agosto de 2005, setembro de 2007, agosto e setembro de 2012 e novembro de 2014. A temperatura apresentou correlação com o número de focos, mas precisa estar associada ao fator da baixa umidade relativa para que possa ser significativa dentro dos modelos, pois se a temperatura for elevada e a umidade relativa do ar também, observa-se então uma diminuição do número de focos como ocorreram nos meses de agosto de 2006 e outubro de 2013.

A radiação solar apresentou valor máximo de 9,2 MJ m-2, entretanto, alta taxa de radiação não significa que o número de focos será máximo, pois, a sua incidência é diretamente afetada pela presença de nuvens. Quando ocorre baixa umidade e alta temperatura as curvas se apresentam em fase (ou seja, os pontos de máximo estão alinhados), porém, analisadas isoladamente, ocorrem defasagens entre as curvas de focos e radiação. Pode-se observar que setembro de 2007 as curvas estão em fase, e em novembro de 2014 observa-se que a radiação e a temperatura são elevadas, porém, em decorrência da alta umidade relativa do ar a ocorrência de focos decresce, representando essa defasagem da análise isoladamente.

Destacam-se os anos de 2005 e 2012 que apresentaram os maiores valores de incidências de focos da série, isso se deve ao acúmulo de material combustível das plantas dos anos precedentes (2004 e 2011, respectivamente), em que ocorreram grandes enchentes no

\section{IPABH}


município, tornando a vegetação mais fraca e propícia à queima, quando submetida às condições climáticas das altas temperaturas e radiação solar e baixa umidade relativa do ar nos anos seguintes, conforme pode ser observado na Figura 1.

Os anos de 2006, 2011 e 2014 apresentaram uma média de focos em torno de 170 registros, quantitativo inferior decorrente da alta umidade relativa apresentando a média acima de $60 \%$.

É apresentado, na Equação 1, o modelo RLM de previsão de focos de queimadas para o município de Corumbá (MS).

$\log (\widehat{N})=1,335-0,032 \times R-0,028 \times U+0,050 \times T$

Onde $\widehat{N}$ é o valor estimado para o número de focos; R é a radiação solar acumulada; U é a umidade relativa; e T é a temperatura máxima.

A estatística descritiva do modelo de regressão aplicado, com variável dependente $\log (\widehat{N})$ e as variáveis preditoras Radiação Solar, Umidade Relativa e Temperatura, resultou no valor de $\mathrm{R}^{2}=0,411$ e indica que o grau de ajustamento das variáveis preditivas foi de $41 \%$ com $\mathrm{p}<0,001$, explicando a variabilidade de saída pelos dados das variáveis meteorológicas preditoras. O erro percentual absoluto médio (MAPE) foi de 33,9\%, cometido entre os valores do logaritmo decimal do número de focos para os valores estimados pela Equação 1. Ao se aplicar o teste de Stein no valor de $\mathrm{R}^{2}$ foi possível verificar que o resultado foi próximo do valor de ajuste resultando em 0,410, o que significa que o modelo pode ser generalizado para diferentes amostras, ocorrendo validação cruzada do modelo.

A estatística F resultou no valor 390,034, que significa que novas variáveis preditoras inseridas no modelo pela configuração do software IBM-SPSS, no modo "stepwise, foi satisfatória para a previsão do número de focos, entretanto a hipótese de independência dos erros analisada pelo teste de Durbin-Watson, foi parcialmente satisfatória, resultando em 0,917.

Com essas análises, pode-se verificar que a técnica de RLM não é o modelo mais adequado para a previsão do número de focos (quando se utiliza como variáveis preditoras somente os dados meteorológicos), pois, não se apresentou estritamente linear e deve-se levar em consideração ainda a possibilidade de inserir outras variáveis que possam contribuir para aumentar o desempenho desse método, como, por exemplo, uma variável associada à ação antrópica, da qual identifica as queimadas de acordo com a ação humana e classifica os focos provenientes de ação natural ou não (White e White, 2016).

Na aplicação da técnica ARIMA de Box-Jenkins, utilizando os dados meteorológicos como variáveis preditoras, houve uma otimização da previsão com o modelo $\operatorname{ARIMA~}(4,0,10)$, ou seja, com quatro termos autorregressivos e dez termos da média móvel. Não foi necessária a diferenciação, ou seja, $d=0$, por se tratar de dados estacionários. O número de ordens autorregressivas foi $\mathrm{p}=4$, sendo necessários quatro períodos de tempo da série no passado para prever o valor atual. $\mathrm{O}$ valor de $\mathrm{q}=10$ especifica que os desvios dos valores médios das séries de cada um dos dez últimos períodos de tempo, são considerados, ao prever os valores atuais da série.

A análise do critério de informações bayesianas aplicadas para comparar os modelos, demonstrou que o modelo ARIMA $(4,0,10)$ é o melhor modelo previsor associado à significância $\mathrm{p}<0,05$. O ajuste do modelo passa a ser de $66,5 \%$, com um erro percentual absoluto médio (MAPE) de 31,6\%, melhorando consideravelmente o desempenho geral do modelo ARIMA ao se comparar à modelagem RLM.

Os gráficos comparativos dos valores dos focos observados e previstos pelas técnicas de previsão RLM e ARIMA estão representados na Figura 2 (a) e (b), respectivamente. 

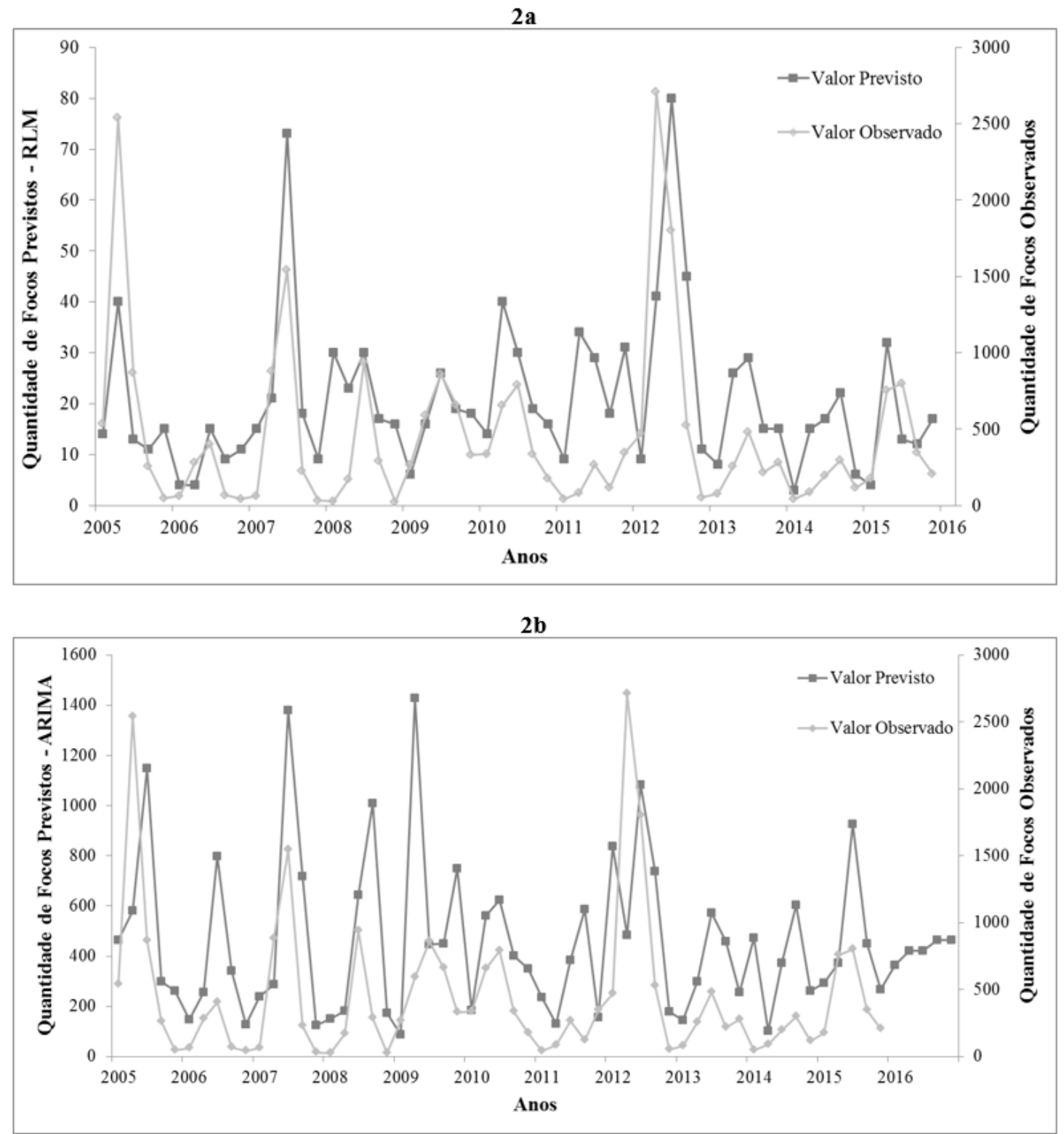

Figura 2. Valores observados e previstos dos focos obtidos nas modelagens de RLM (Figura 2a) e ARIMA (Figura 2b), no período JASON para a série histórica de 2005 a 2015 no município de Corumbá (MS).

De acordo com a Figura 2a para o modelo RLM, é possível constatar que os gráficos dos focos previstos e dos focos observados estão em fase com picos de máximo e mínimo coincidentes e o crescimento e decrescimento com as mesmas características ao longo de toda a curva, em diferentes escalas por terem sido aplicados de forma parametrizada na regressão com a utilização do logaritmo decimal, cabe salientar, que para obter os dados previstos, aplicase o antilogaritmo no resultado da equação de modelagem. No entanto, o viés da previsão foi subestimar os valores dos focos, acertando em menos de $50 \%$ os dados de saída. A partir da Figura 2b para o modelo ARIMA é possível observar que as curvas dos valores previstos e dos valores estimados estão em fase e apresentam as condições de tonicidade coincidentes e os picos de máximo e mínimo com o mesmo delineamento, sendo possível de realizar a previsão com cinco passos posteriores com essa mesma precisão, e apesar de também subestimar os dados de saída, os acertos foram superiores a $50 \%$ dos casos.

Os gráficos dos resíduos dos dois modelos estão representados na Figura 3, sendo, para o RLM (Figura 3a) e para o ARIMA (Figura 3b), respectivamente.

\section{IPABH}



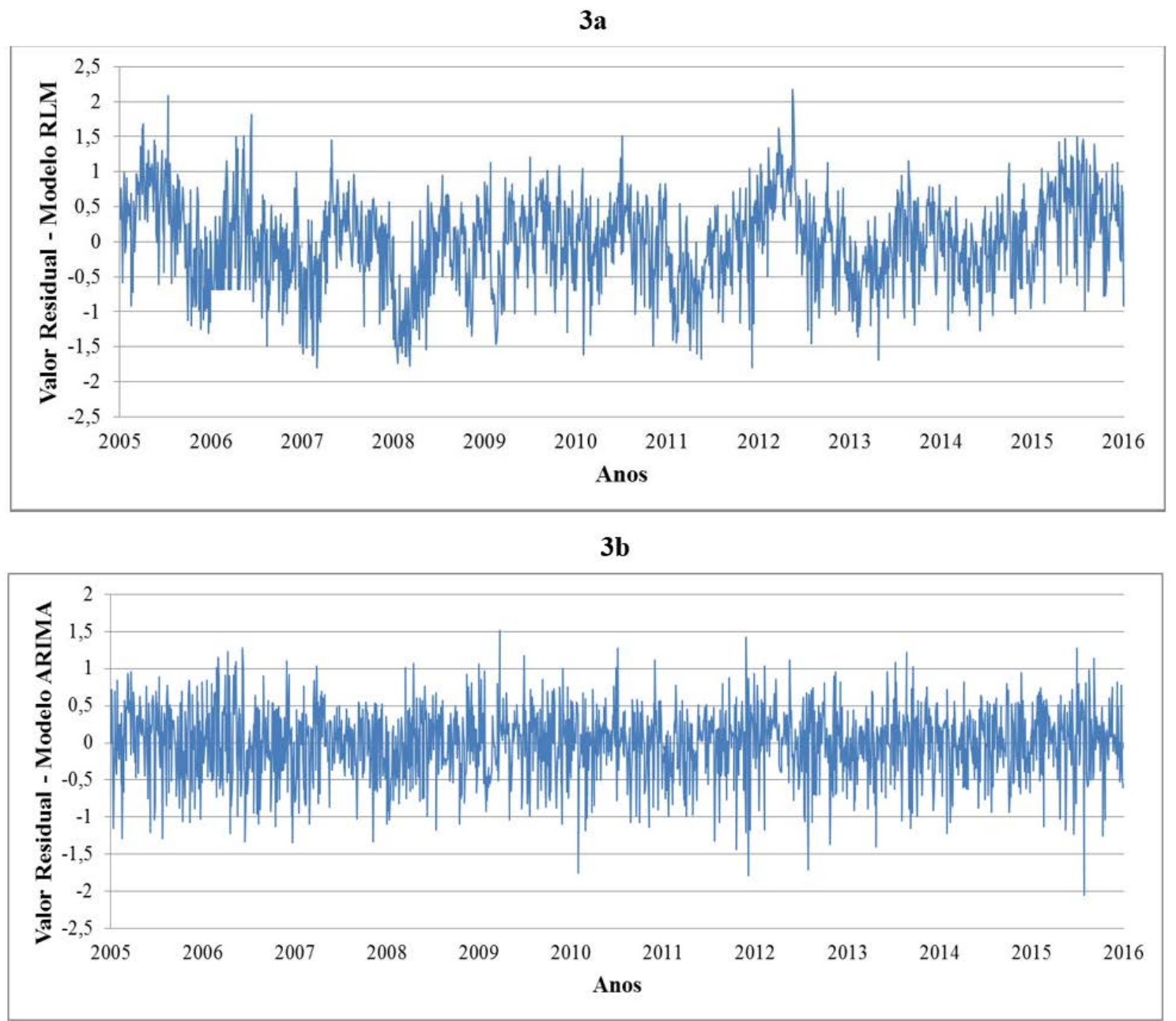

Figura 3. Valores residuais nas modelagens de RLM (Figura 2a) e ARIMA (Figura 2b), no período JASON para a série histórica de 2005 a 2015 do município de Corumbá (MS).

Considerando a análise de resíduos, pode-se enfatizar que o modelo ARIMA pode ser utilizado para fazer inferências além da amostra de dados utilizadas, entretanto o modelo RLM (Figura 3a) para a previsão dos focos a partir de dados preditores estritamente meteorológicos, não se apresentou uma técnica adequada para a previsão, o que evidencia não se tratar de um modelo de características estritamente lineares, e os resíduos oscilam consideravelmente em torno de zero. Já a análise do modelo ARIMA explica a variância das variáveis meteorológicas para a previsão dos focos no que tange em quão propício estão de ocorrer. Para melhorar a previsão de quantos focos poderão ocorrer é necessário inserir variáveis que especifiquem as causas da ocorrência de cada foco (naturais ou antrópicas), ou até mesmo variáveis da área agrícola e pecuária.

Na análise dos resíduos na modelagem ARIMA (Figura 3b), o teste de Durbin-Watson $(\mathrm{D}=1,97)$ mostrou que a hipótese de interdependência dos erros é satisfeita, pois se apresenta próxima do valor esperado (2) e o desempenho geral da técnica foi de $68,4 \%$ com p $<0,002$, sendo capaz de fazer a previsão cinco passos adiante com essa mesma precisão.

A partir da análise do gráfico de resíduos, pode-se ainda constatar que o modelo ARIMA é mais ajustado, pois apresenta valores mais próximos de zero e com menor coeficiente de variação. Os estimadores não são enviesados e o modelo ARIMA apresentou resultados significativamente melhores para prever a saída de dados do número de focos a partir das variáveis meteorológicas.

As modelagens de RLM e ARIMA foram aplicadas para a previsão do número de focos a 
partir de dados preditores meteorológicos, e foi possível observar que há a necessidade de inserir outras variáveis para se utilizar esse tipo de técnica de previsão, no intuito de melhorar a saída de dados e consequentemente diminuir os valores residuais.

\section{CONCLUSÕES}

Foi possível verificar a correlação dos fatores meteorológicos com o número de focos, que demonstraram a partir dos resultados da correlação de Pearson e da análise gráfica que essas variáveis guardam uma importante relação com as condições da vegetação do Pantanal de Corumbá-MS e afetam diretamente a ocorrência de focos de queimadas e incêndios, onde se destacaram a radiação solar, a umidade relativa e a temperatura.

Foram aplicadas as técnicas de análises multivariadas de dados utilizando as modelagens RLM e ARIMA, em que o modelo RLM explicou $41 \%$ da variância do número de focos, mostrando-se uma técnica não eficiente para a previsão, no que tange as variáveis meteorológicas como preditoras, demonstrando a necessidade de inserir outras variáveis relacionadas à ação antrópica, tais como as atividades de agropecuária.

Já, o modelo ARIMA $(4,0,10)$ apresentou resultados mais satisfatórios em relação à modelagem RLM, possibilitando explicar a variância do número de focos em 66,5\%, o que demonstra ser a técnica mais adequada para a previsão quando comparada com a técnica RLM. No entanto, espera-se que o desempenho dessa técnica melhore ao se realizar a inserção de outras variáveis. Outras modelagens podem ser testadas para a previsão dos focos a partir das variáveis estritamente meteorológicas e fica como sugestão para trabalhos futuros.

\section{REFERÊNCIAS}

ALMEIDA, C. T.; OLIVEIRA JÚNIOR, J. F.; DELGADO, R. C.; CUBO, P.; RAMOS, M. C. Spatiotemporal rainfall and temperature trends throughout the Brazilian Legal Amazon, 1973-2013. International Journal of Climatology, v. 37, n. 4, p. 2013-2026, 2016. https://doi.org/10.1002/joc.4831

ARTAXO, P.; OLIVEIRA, P, H.; LARA, L. L.; PAULIQUEVIS, T. M.; RIZZO, L. V.; JUNIOR, C. P. Efeitos climáticos de partículas de aerossóis biogênicos e emitidos em queimadas na Amazônia. Revista Brasileira de Meteorologia, v. 21, n. 3a, p. 168-189, 2006.

BRASIL. Ministério das Minas e Energia. RadamBrasil. Folha SE. 21. Corumbá e Folha SE. 20. Geologia, Pedologia, Geomorfologia, Vegetação e Uso e Ocupação da Terra. Rio de Janeiro,1982. 448 p.

BRITO, T. T.; OLIVEIRA JÚNIOR, J. F.; LYRA, G. B.; GOIS, G.; ZERI, M. Multivariate analysis applied to monthly rainfall over Rio de Janeiro state, Brazil. Meteorology and Atmospheric Physics, v. 129, n. 5, p. 469-478, 2016.

CAÚLA, R. H.; OLIVEIRA JÚNIOR, J. F.; GOIS, G.; DELGADO, R. C.; PIMENTEL, L. C. G.; TEODORO, P. E. Nonparametric statistics applied to fire foci obtained by meteorological satellites and their relationship to the MCD12Q1 product in the state of Rio de Janeiro, Southeast - Brazil. Land Degradation \& Development, v. 28, n. 3, p. 1056-1067, 2016. https://doi.org/10.1002/ldr.2574

CLEMENTE, S. S.; OLIVEIRA JÚNIOR, J. F.; LOUZADA, M. A. P. Focos de calor na Mata Atlântica do Estado do Rio de Janeiro. Revista Brasileira de Meteorologia, v. 32, n. 4, p. 669-677, 2017. 
DEPPE, F.; PAULA, E. V.; MENEGHETTE, C. R.; VOSGERAU, J. Comparação de índice de risco de incêndio florestal com focos de calor no Estado do Paraná. Floresta, v. 34, n. 2, p. 119-126, 2004. http://dx.doi.org/10.5380/rf.v34i2.2382

FREITAS, S. R.; LONGO, K. M.; SILVA DIAS, M. A. F. S.; SILVA DIAS, P. L. S. Emissões de Queimadas em ecossistemas da América do Sul. Estudos Avançados, v. 19, n. 53, p. 167-185, 2005. http://dx.doi.org/10.1590/S0103-40142005000100011

GONÇALVES, A. B.; VIEIRA, A. Grandes incêndios florestais, erosão, degradação e medidas de recuperação dos solos. Minho: Universidade do Minho, 2013. 299 p.

HAIR JR., J.; ANDERSON, R.; TATHAM, R.; BLACK, W. Análise multivariada de dados. Porto Alegre: Bookman, 2005. 596 p.
INSTITUTO BRASILEIRO DE GEOGRAFIA E ESTATÍSTICA - IBGE. Cidades Mato Grosso do Sul - Corumbá MS. Disponível em: https://cidades.ibge.gov.br/brasil/ms/corumba. Acesso em: 08 fev. 2016.

MAGI, B. I.; RABIN, S.; SHEVLIAKOVA, E.; PACALA, S. Separating agricultural and nonagricultural fire seasonality at regional scales. Biogeosciences, v. 9, n. 8, p. 3003-3012, 2012. https://doi.org/10.5194/bg-9-3003-2012

MORETTIN, P. A.; TOLOI, C. M. C. Análise de séries temporais. São Paulo: Edgard Blüncher, 2006. 531 p.

MORRISON, J. H. Caring for country: indigenous people managing country using fire, with particular emphasis on Northern Australia. In: INTERNATIONAL WILDLAND FIRE CONFERENCE, 9., 2014, Sydney. Abstract and Papers... Sydney: ISDR, 2014.

NOGUEIRA, J. S.; SANTOS, A. C. A. Análise do material particulado no Pantanal MatoGrossense. Revista Brasileira de Meteorologia, v. 30, n. 3, p. 254-264, 2015.

NUNES, M. T. O.; SOUSA, G. M.; TOMZHINSKI, G. W.; OLIVEIRA-JÚNIOR, J. F.; FERNANDES, M. C. Factors Influencing on Susceptibility Forestry Fire in Itatiaia National Park. Anuário do Instituto de Geociências, v. 38, n. 1, p. 54-62, 2015.

PEREIRA, A. A.; PEREIRA, J. A. A.; MORELLI, F.; BARROS, D. A.; ACERBI JR., F. W.; SCOLFORO, J. R. S. Validação de focos de calor utilizados no monitoramento orbital de queimadas por meio de imagens TM. Cerne, v. 18, p. 335-343, 2012.

SANTOS, A. C. A.; NOGUEIRA, J. S. Análise do material particulado no Pantanal MatoGrossense. Revista Brasileira de Meteorologia, v. 30, n. 3, p. 254-264, 2015.

SILVA, R. A. Incêndio Florestal. In: TOCCHETTO, D. Perícia ambiental criminal. Campinas: Millennium, 2014. p. 351 - 406.

SOARES, R. V.; BATISTA, A. C.; NUNES, J. R. S. Incêndios florestais no Brasil: o estado da arte. Curitiba: Produção Independente, 2009. 246 p.

TORRES, F. T. P.; RIBEIRO, G. A.; MARTINS, S. V.; LIMA, G. S. Correlações entre os elementos meteorológicos e as ocorrências de incêndios florestais na área urbana de Juiz de Fora, MG. Revista Árvore, v. 35, n. 1, p. 143-150, 2011. http://dx.doi.org/10.1590/S0100-67622011000100017 
TREJO, D. A. R. Fire Regimes, Fire Ecology, and Fire Management in Mexico. Journal of the Human Environment, v. 37, n. 7, p. 548-556, 2008. https://doi.org/10.1579/0044-744737.7.548

VIGANÓ, H. H. G.; SOUZA, C. C.; CRISTALDO, M. F.; JESUS, L. Redes Neurais Artificiais na Previsão de Queimadas e Incêndios no Pantanal. Revista Brasileira de Geografia Física, v. 10, n. 5, p. 1355-1367, 2017. http://dx.doi.org/10.26848/rbgf.v.10.p1355-1367

WHITE, B. L. A.; WHITE, L. A. S. Queimadas controladas e incêndios florestais no Estado de Sergipe, Brasil, entre 1999 e 2015. Floresta, v. 46, n. 4, p. 561-570, 2016. http://dx.doi.org/10.5380/rf.v46i4.47036 


\begin{tabular}{|} 
Ambiente \& Água - An Interdisciplinary Journal of Applied Science \\
ISSN 1980-993X - doi:10.4136/1980-993X \\
www.ambi-agua.net \\
E-mail: ambi.agua@gmail.com
\end{tabular}

\title{
Dinâmica temporal da pegada hídrica por cultivar de soja em polo de grãos no Oeste do Pará, Amazônia
}

\author{
ARTICLES doi:10.4136/ambi-agua.2051
}

Received: 27 Nov. 2016; Accepted: 01 Sep. 2018

\section{Douglas Cavalcante Costa ${ }^{1 *}$; Lucieta Guerreiro Martorano ${ }^{2}$; José Reinaldo da Silva Cabral de Moraes ${ }^{3}$; Leila Sheila Silva Lisboa ${ }^{4}$; Rubismar Stolf ${ }^{1}$}

\author{
${ }^{1}$ Universidade Federal de São Carlos (UFSCar), Araras, SP, Brasil \\ Centro de Ciências Agrárias (CCA). E-mail: eng.douglascavalcante@gmail.com, stolfrubismar@gmail.com \\ ${ }^{2}$ Empresa Brasileira de Pesquisa Agropecuária (EMBRAPA), Belém, PA, Brasil \\ Laboratório de Agrometeorologia. E-mail: lucieta.martorano@embrapa.br \\ ${ }^{3}$ Universidade Estadual Paulista "Júlio de Mesquita Filho" (UNESP), Jaboticabal, SP, Brasil \\ Departamento de Ciências Agrárias. E-mail: reinaldojmoraes@gmail.com \\ ${ }^{4}$ Escola Superior de Agricultura Luiz de Queiroz (Esalq-USP), Piracicaba, SP, Brasil \\ Departamento de Ciências Exatas. E-mail: leilasheila@gmail.com \\ ${ }^{*}$ Corresponding author
}

\section{RESUMO}

O objetivo neste trabalho foi analisar a dinâmica temporal da pegada hídrica de oito cultivares de soja, plantadas na região do Oeste do Pará. Foram utilizados dados meteorológicos correspondentes ao período de 2009 a 2014 para calcular as taxas evapotranspiratórias da cultura. Como a Pegada Hídrica é subdividida em verde, azul e cinza e, na região os cultivos não são irrigados contabilizou-se apenas a verde e a cinza. A $\mathrm{PH}_{\text {verde }}$ foi estimada considerandose o total de água consumida durante o ciclo de cada cultivar. A $\mathrm{PH}_{\text {cinza }}$ foi avaliada utilizando como fator contaminante em corpos hídricos o composto nitrato que está presente nos fertilizantes nitrogenados, conforme as concentrações aceitáveis pelo CONAMA 357/2005. Considerou-se dois valores para as doses de $\mathrm{N}$, sendo $30 \mathrm{~kg} \mathrm{ha}^{-1}$ com base na adubação descrita na literatura, bem como o $\mathrm{N}$ existente nas formulações (2:20:20) dos adubos vendidos na região, sendo $2 \mathrm{~kg} \mathrm{ha}^{-1}$ o máximo utilizado na adubação de cobertura. Entre as oito cultivares analisadas, em termos de indicador de baixa pegada hídrica, as cultivares BRS 278 RR; BRS 325 RR e BRS 333 RR foram as mais expressivas no polo de grãos no oeste do Pará, evidenciando o uso eficiente da água disponível em todos os anos/safras analisados. A soja produzida no oeste do Pará possui baixa pegada hídrica cinza. Todavia, os valores de redução da produtividade em anos safra na região comprometem a pegada hídrica verde pela sojicultura na região, evidenciando que esse indicador deve ser analisado considerando as especificidades de cada cultivar de soja. O valor da pegada hídrica total estimada neste trabalho foi inferior aos obtidos na literatura, reforçando a importância de estimar a Pegada Hídrica (PH) como indicador de uso consuntivo de água em cultivos de grãos na Amazônia.

Palavras-chave: indicador ambiental, nitrato, uso consuntivo. 


\title{
Temporal dynamics of the water footprint of soybean hub grains in Western Pará, Amazon
}

\begin{abstract}
This study analyzed the time dynamics of the water footprint of eight soybean cultivars planted in the Western Pará, Amazon. Meteorological data between 2009 and 2014 were used to calculate the crop's evapotranspiration rates. Since the water footprint is subdivided into green, blue, and grey, and the crops are not irrigated in the region, only the green and grey footprints were used. WFgreen (water footprint green) was estimated considering the total amount of water consumed during the cycle of each cultivar. WFgrey was assessed using the nitrate present in nitrogen fertilizers as contaminating factor in water bodies according to the concentrations accepted by CONAMA 357/2005. Two $\mathrm{N}$ dose values were considered, i.e., $30 \mathrm{~kg} \mathrm{ha}^{-1}$ based on fertilizer values tested in the literature and the $\mathrm{N}$ present in the formulations (2:20:20) of the fertilizers sold in the region, while the maximum used in top dressing is $2 \mathrm{~kg} \mathrm{ha}^{-1}$. Among the eight cultivars analyzed, $\mathrm{C} 1$ had the smallest water footprint, which shows the efficient use of the water available in every year/harvest analyzed. The total water footprint presented in this study highlights the importance of the methodology to estimate the consumptive use of water in grain production centers. The soybean produced in western Pará has a small grey water footprint, but the cultivars must be highly productive to reduce the green water footprint of soy farming in the region. The definition of the water footprint aids in the strategic planning of the management of water resources in grain production areas in the Amazon.
\end{abstract}

Keywords: consumptive use, environmental indicator, nitrate.

\section{INTRODUÇÃO}

A quantidade de água potável necessária para suprir a demanda das populações vem aumentando, tanto para consumo quanto para produzir alimento, em períodos de escassez hídrica no solo. A acelerada degradação da qualidade das águas pela agricultura tem sido atribuída, principalmente ao fator erosivo das chuvas em solos expostos e ao uso indiscriminado em cultivos irrigados. A demanda crescente por produtos agrícolas de uso alimentar e nãoalimentar, bem como as crescentes mudanças nos padrões de consumo, principalmente de carne e açúcar, têm contribuído significativamente na redução da oferta de água e na intensificação da poluição em corpos hídricos (Lamastra et al., 2014).

No Brasil, a estimativa do Instituto Brasileiro de Geografia e Estatística (IBGE, 2016) foi de 17 milhões de habitantes para o início do século XX, porém projeta-se para 2020 valores da ordem de 212 milhões de habitantes, no País. As projeções do Department of Economic and Social Affairs of the United Nations Secretariat (DESA) apontam que a população brasileira deverá atingir 238 milhões de habitantes em 2050, o que pode intensificar a disputa por melhores classes de solos, condições climáticas, água potável, alimentos e insumos agrícolas; e ainda, estimam que 2,3 bilhões de pessoas estarão vivendo em áreas com elevada restrição hídrica (UNESCO, 2015a; 2016). Portanto, nesse cenário, a humanidade poderá presenciar crises, sobretudo na oferta de alimentos e de água potável, intensificando-se os riscos de perda da qualidade hídrica às populações (Ercin e Hoekstra, 2014).

$\mathrm{Na}$ Amazônia, áreas cultivadas com grãos em Mato Grosso foram ampliando-se para áreas mais ao norte da região, consolidando-se importantes polos no Pará como, por exemplo, no oeste do Estado. Nesse polo de produção participam com a maior área cultivada os municípios de Santarém, Belterra e Mojuí dos Campos. Essas áreas, anteriormente foram desflorestadas 
com incentivo de programas de desenvolvimento na região, como o de integração da Amazônia às demais regiões brasileiras. No final da década de 1990, com a estruturação do terminal graneleiro, foram abertas novas frentes voltadas à exportação de grãos, o que estimulou a imigração de agricultores dispostos a investir na região. Vale ressaltar que a soja tem se destacado como cultura rentável economicamente, totalizando 41 mil hectares plantados (Pará, 2016).

Entre as variáveis climáticas, a oferta hídrica apresenta-se como fator limitante à obtenção de rendimentos máximos em safras agrícolas. A soja (Glycine max), de acordo com Farias et al. (2007), nos períodos de germinação-emergência e floração-enchimento de grãos a evapotranspiração real diária varia entre 7 a $8 \mathrm{~mm} \cdot \mathrm{dia}^{-1}$, ou seja, nos períodos vegetativos e reprodutivos a soja pode utilizar entre 450 a $800 \mathrm{~mm}$ de água nos processos evapotranspiratórios até completar o seu ciclo. A disponibilidade de água no solo é fator condicionante ao atendimento da planta à demanda hídrica da atmosfera (Martorano et al., 2009). Em períodos de escassez de água no solo os sojicultores podem adotar estratégias de reposição hídrica usando técnicas de irrigação, pois a produção de alimentos deverá suprir as necessidades da população em crescimento no globo terrestre, o que pode refletir na elevação da competitividade por água doce.

A pegada hídrica $(\mathrm{PH})$ contabiliza o uso consuntivo de água e apresenta-se como uma ferramenta de gestão eficiente de recursos hídricos pelo setor produtivo, como nas atividades agropecuárias de uma região. Índices apontando valores da população na condição de extrema pobreza, acesso desigual no abastecimento de água, escassez de serviços de saneamento básico e, o baixo gerenciamento dos recursos hídricos são fatores preponderantes de ameaças à obtenção do desenvolvimento sustentável no planeta (UNESCO, 2015b). Estima-se que até 2050 haverá um aumento mundial de 55\% da demanda hídrica, especialmente na África e Ásia Central. Os padrões de consumo da humanidade tendem a elevar as demandas por recursos naturais e reduzir a oferta de bens e serviços ecossistêmicos (MEA, 2003).

Para contabilizar os diferentes usos da água, utilizam-se indicadores de desempenho do uso eficiente da água, como por exemplo, a Pegada Hídrica (PH). A metodologia da Pegada Hídrica apresenta-se como um importante indicador de prestação de serviços ecossistêmicos em provisão, regulação e suporte hídrico às populações. A PH é subdivida em: azul, verde e cinza (Hoekstra et al., 2011), sendo que a Pegada Hídrica Azul $\left(\mathrm{PH}_{\mathrm{azul}}\right)$ indica o uso consuntivo da água superficial ou subterrânea disponível à cultivos irrigados. A Pegada Hídrica Verde $\left(\mathrm{PH}_{\text {verde }}\right)$ refere-se à precipitação que não escoa ou não repõe a água subterrânea, que é armazenada no solo ou na vegetação, ou seja, é a água consumida no processo evapotranspiratório das culturas. A Pegada Hídrica Cinza $\left(\mathrm{PH}_{\text {cinza }}\right)$ indica o nível de poluição na cadeia de produtos ou de processo, sendo definida como a água necessária para diluir/depurar o poluente. Assim, na Amazônia, o manejo de fertilizante e defensivo agrícola pode comprometer a qualidade hídrica em áreas produtivas. $\mathrm{O}$ objetivo neste trabalho foi avaliar a dinâmica temporal da pegada hídrica da soja considerando cultivares e anos/safras diferentes no polo de grãos Santarém/Belterra, na Amazônia.

\section{MATERIAIS E MÉTODOS}

Na Figura 1, destacam-se as áreas destinadas para agricultura anual (milho, feijão, soja), onde a soja é plantada desde 2006. Atualmente o polo de grãos de Santarém/Belterra é reconhecido como uma das principais rotas para o escoamento de grãos do Brasil. Nessa região predomina a tipologia climática $\mathrm{Am}_{3}$, de acordo com a adaptação na metodologia de Köppen por Martorano et al. (1993). As chuvas anuais variam entre 2.000 a $2.300 \mathrm{~mm}$, ocorrendo no mês de menor oferta pluvial valores abaixo de $60 \mathrm{~mm}$. A temperatura máxima do ar varia entre 
30,5 a $32^{\circ} \mathrm{C}$ e as mínimas entre 21,0 a $22,5^{\circ} \mathrm{C}$. O período mais chuvoso ocorre de dezembro a maio com cerca de $80 \%$ dos totais pluviais e, entre junho a novembro são contabilizados o restante do volume precipitado na região (Varela-Ortega et al., 2013).

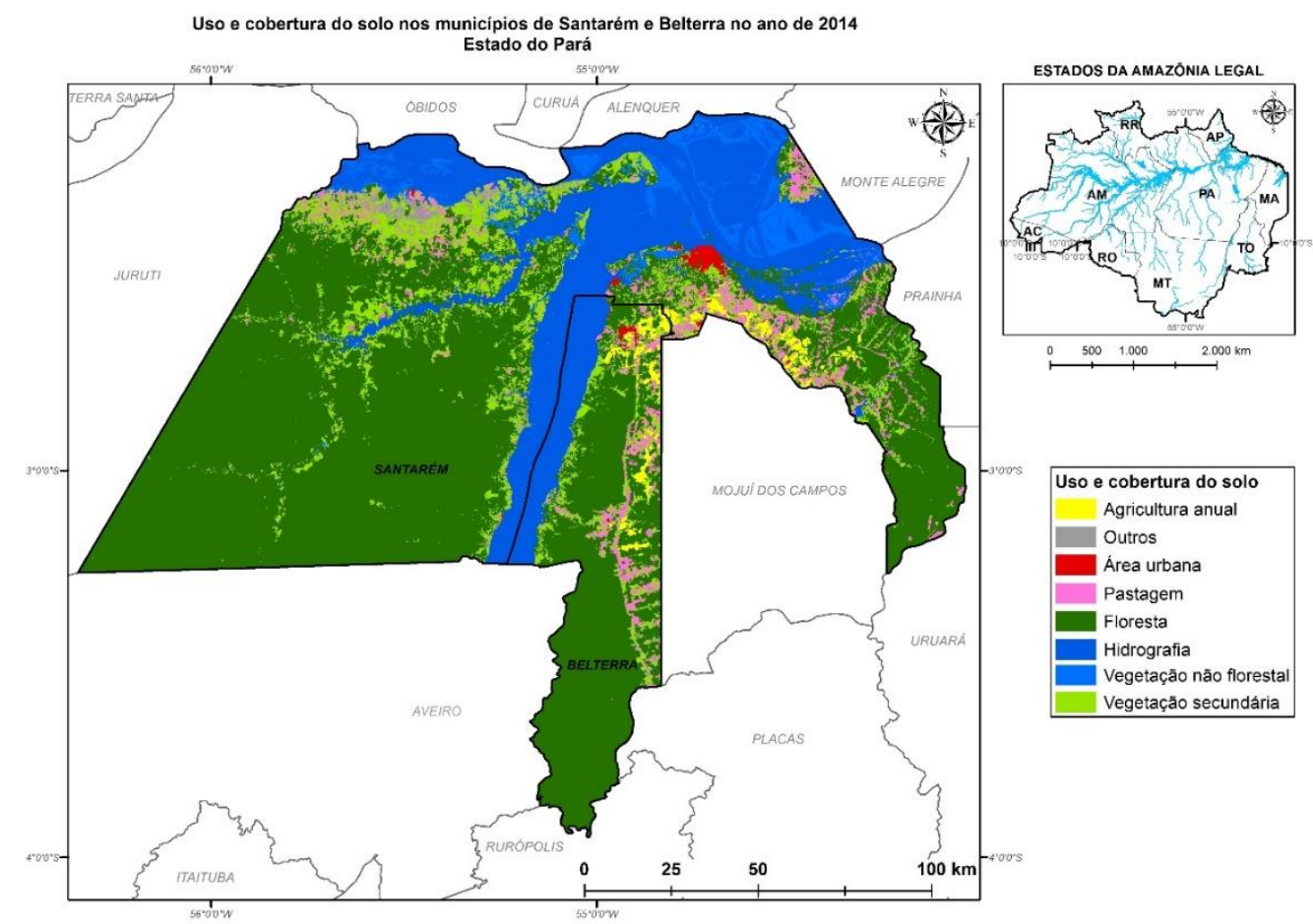

Figura 1. Mapa de localização do polo de grãos Santarém/Belterra no oeste do Pará, Amazônia.

Para calcular a pegada hídrica total das oito cultivares testadas na região, fez-se as estimativas das pegadas hídricas verde e cinza a partir dos valores em rendimento dessas cultivares, mas os valores de estimativas de taxas evapotranspiratórias foram contabilizados considerando a duração do ciclo e condições térmico-hídricas em cada ano/safra, no período de 2009 a 2014, conforme descrito a seguir.

Como na região de estudo os cultivos não são irrigados, a $\mathrm{PH}_{\mathrm{azul}}$ foi desconsiderada na contabilização da pegada hídrica total.

\subsection{Pegada hídrica verde (PHverde)}

Para o cálculo de evapotranspiração da cultura no polo de grãos de Santarém/Belterra foi utilizado o modelo CROPWAT 8.0 que foi desenvolvido pela Organização das Nações Unidas para Agricultura e Alimentação (FAO, 2010). Nessa ferramenta foram inseridos os dados mensais, correspondentes ao período de 2009 a 2014. Assim, inseriram-se os valores de precipitação pluvial $(\mathrm{mm})$, temperatura máxima e mínima $\left({ }^{\circ} \mathrm{C}\right)$, umidade relativa do $\operatorname{ar}(\%)$ e velocidade do vento $\left(\mathrm{m} \mathrm{s}^{-1}\right)$, oriundos de estação automática do Instituto Nacional de Meteorologia (INMET) e posto pluvial da Agência Nacional de Águas (ANA). Os valores de coeficiente da cultura (Kc) adotados foram $0,4,1,15$ e 0,5, correspondentes a fase inicial, média e final, respectivamente (Allen et al., 1998). Identifica-se na Amazônia a predominância de Latossolo Amarelo, o que determinou os valores de entrada gerais do solo no software. A $\mathrm{PH}_{\text {verde }}$ foi estimada baseando-se nos dados de clima, de precipitação e no período de semeadura de cada cultivar apontados na Tabela 1. Utilizou-se a metodologia de Hoekstra et al. (2011), Equação 1. 
$\mathrm{PH}_{\mathrm{verde}}=\frac{\mathrm{C}_{\mathrm{verde}}}{\mathrm{R}}$

Em que, $\mathrm{PH}_{\text {verde }}$ é a Pegada Hídrica Verde da cultura $\left(\mathrm{m}^{3} \mathrm{t}^{-1}\right), \mathrm{C}_{\text {verde }} \mathrm{o}$ consumo de água verde $\left(\mathrm{m}^{3} \mathrm{ha}^{-1}\right)$; e $\mathrm{R}$ é o rendimento da cultura $\left(\mathrm{t} \mathrm{ha} \mathrm{a}^{-1}\right)$.

O componente da $\mathrm{C}_{\text {verde }}$ foi estimado com base na evapotranspiração diária acumulada (ET, $\mathrm{mm} \operatorname{dia}^{-1}$ ) durante o ciclo completo de desenvolvimento da cultura, conforme Equação 2.

$$
\mathrm{C}_{\mathrm{verde}}=10 \times \sum_{\mathrm{d}=1}^{\mathrm{pdc}} \mathrm{ET}_{\mathrm{verde}}
$$

Em que, ET verde é a evapotranspiração da cultura, considerando apenas a oferta pluvial, conforme os pressupostos de Hoekstra et al. (2011) como água verde. O fator 10 refere-se a conversão da unidade de $\mathrm{ET}_{\text {verde }}$ em milímetros para volumes de água por superfície terrestre, em $\mathrm{m}^{3} \mathrm{ha}^{-1}$. O somatório considera desde o dia de semeadura $(\mathrm{d}=1)$ até a colheita e pdc, corresponde a duração do período de desenvolvimento da cultivar, adotada neste artigo como o número de dias conforme as especificações de cada cultivar.

\subsection{Dados das cultivares de soja}

Na Tabela 1 apresentam-se as cultivares utilizadas, contabilizando-se o número de dias da emergência até a floração e, o número de dias até o final do ciclo, bem como o rendimento de grãos $\left(\mathrm{t} \mathrm{ha}{ }^{-1}\right)$ de cada cultivar. Ressalta-se que essas oito cultivares $\left(\mathrm{C}_{1}\right.$ a $\left.\mathrm{C}_{8}\right)$ foram materiais testados na região por Borges et al. (2012), ordenados conforme o rendimento de grãos. Ressalta-se que em cada ano/safra as estimativas da pegada hídrica foram realizadas considerando-se os rendimentos obtidos por Borges et al. (2012), variando-se as condições meteorológicas mensais ocorridas no período entre 2009 a 2014. Totalizou-se a precipitação pluvial (mm) até a floração e da emergência ao final de cada ciclo dessas cultivares, no polo de grãos Santarém/Belterra.

Tabela 1. Cultivares, dias até a floração, número de dias para completar o ciclo, rendimento de soja (Glycine max), volume médio (2009 a 2014) de água precipitada (PRP) até a floração e a PRP até o final do ciclo para Santarém e Belterra, Pará.

\begin{tabular}{|c|c|c|c|c|c|c|c|}
\hline \multirow{2}{*}{\multicolumn{2}{|c|}{$\begin{array}{l}\text { Cultivares e rendimento }\left(\mathrm{t} \mathrm{ha}^{-1}\right) \\
\text { indicado no "parêntese" }\end{array}$}} & \multirow{2}{*}{$\begin{array}{c}\text { Floração } \\
\text { (dias) }\end{array}$} & \multirow{2}{*}{$\begin{array}{l}\text { Ciclo } \\
\text { (dias) }\end{array}$} & \multicolumn{2}{|c|}{ SANTARÉM } & \multicolumn{2}{|c|}{ BELTERRA } \\
\hline & & & & \multirow{2}{*}{$\begin{array}{c}\text { PRP }(\mathrm{mm}) \\
\text { Floração }\end{array}$} & \multirow{2}{*}{$\begin{array}{c}\text { PRP (mm) } \\
\text { Ciclo }\end{array}$} & \multirow{2}{*}{$\begin{array}{c}\text { PRP }(\mathrm{mm}) \\
\text { Floração }\end{array}$} & \multirow{2}{*}{$\begin{array}{c}\text { PRP (mm) } \\
\text { Ciclo }\end{array}$} \\
\hline $\mathrm{C}_{1}$ & BRS 278RR $(2,7)$ & 46 & 107 & & & & \\
\hline $\mathrm{C}_{2}$ & BRS 325RR $(2,5)$ & 42 & 103 & 337,8 & 1204,1 & 271,3 & 782,1 \\
\hline $\mathrm{C}_{3}$ & BRS 333RR $(2,8)$ & 42 & 105 & 337,8 & 1204,1 & 271,3 & 788,3 \\
\hline $\mathrm{C}_{4}$ & P98Y70 $(2,7)$ & 45 & 103 & 345,4 & 1204,1 & 309,4 & 782,1 \\
\hline $\mathrm{C}_{5}$ & BRS 279RR $(2,4)$ & 42 & 96 & 337,8 & 1162,1 & 271,3 & 681,2 \\
\hline $\mathrm{C}_{6}$ & BRS 8990RR $(2,3)$ & 42 & 103 & 337,8 & 1204,1 & 271,3 & 782,1 \\
\hline $\mathrm{C}_{7}$ & BRS 271RR $(2,1)$ & 42 & 105 & 337,8 & 1204,1 & 271,3 & 788,3 \\
\hline $\mathrm{C}_{8}$ & M8766RR $(1,9)$ & 40 & 96 & 322,9 & 1162,1 & 265,6 & 681,2 \\
\hline
\end{tabular}

\subsection{Pegada hídrica cinza (PHcinza)}

A estimativa da $\mathrm{PH}_{\text {cinza }}$ foi realizada com base em doses de fertilizante nitrogenado empregado no processo de adubação de culturas, considerado como fonte difusa de poluição dos corpos hídricos. Utilizou-se a metodologia de Hoekstra et al. (2011), Equação 3.

$\mathrm{PH}_{\text {cinza }}=\frac{(\alpha \times \mathrm{TAQ}) /(\text { Cmáx }- \text { Cnat })}{\mathrm{R}}$

\section{IPABH}


Em que, PHcinza é a pegada hídrica cinza $\left(\mathrm{m}^{3} \mathrm{t}^{-1}\right)$, $\alpha$ é a fração de lixiviação do fertilizante, TAQ é a taxa de aplicação por hectare de nitrogênio em campo $\left(\mathrm{kg} \mathrm{ha}^{-1}\right)$, $\mathrm{c}_{\text {máx }}$ é a concentração máxima aceitável e a c nat é a concentração natural do poluente (nitrato) no corpo hídrico e R, o rendimento da cultivar.

Neste trabalho atribuiu-se o valor de $10 \%$ para a fração de lixiviação de fertilizante nitrogenado, recomendado por Hoekstra et al. (2011). O valor limite aceitável do nitrato foi considerado de acordo com a legislação CONAMA 357/2005 que categoriza como classe 3 para águas doces e estabelece como quantidade máxima permitida de $10 \mathrm{mg} \mathrm{L}^{-1}$. Atribuiu-se o valor 0 (zero) para a concentração natural de nitrato em corpos hídricos (Wu et al., 2016). Considerou-se nas estimativas de $\mathrm{PH}_{\text {cinza }}$ a adubação de nitrogênio $(\mathrm{N}$ ) conforme as recomendações de Petter et al. (2012) que preconiza $30 \mathrm{~kg} \mathrm{ha}^{-1}$. Também foram estimados os valores de $\mathrm{PH}_{\text {cinza }}$ para o $\mathrm{N}$ existente nas formulações (2:20:20) dos adubos comercializados na região, sendo $2 \mathrm{~kg} \mathrm{ha}^{-1} \mathrm{o}$ máximo utilizado na adubação de cobertura.

Fez-se a análise de variância considerando-se o delineamento em blocos casualizados, onde se testou cada cultivar. Assim, no teste de significância (ANOVA) as médias foram comparadas pelo teste de Tukey $(\mathrm{p}<0,05)$ avaliando-se a diferença entre a pegada hídrica total de cada cultivar, sendo que o menor valor de pegada hídrica (a) representa o melhor desempenho pela cultivar comparadas duas a duas.

\section{RESULTADOS E DISCUSSÃO}

Considerando que a semeadura das cultivares foram realizadas em $1^{\circ}$ de janeiro de cada ano safra analisado, é possível observar na Figura 2 que nos meses de janeiro e fevereiro, quando as cultivares estariam entre as fases de crescimento vegetativo e início da floração, que os eventos pluviais em Santarém foram melhor distribuídos ao comparar com Belterra, conforme descritos na análise dos box-plots. Todavia, apesar da maior simetria entre os eventos pluviais em Santarém, identificou-se maiores discrepâncias (outliers) quanto ao volume precipitado diariamente nesse período em relação a Belterra. No final de fevereiro, em Santarém, foram registradas cotas pluviais médias que atingiram cerca de $150 \mathrm{~mm}$. No período correspondente à plena floração, formação de legumes, enchimento e maturação de grãos, percebe-se que as chuvas em Belterra mantiveram assimetrias positivas, ou seja, os valores pluviais ficaram acima da normal climatológica, indicando manutenção da oferta hídrica até o final do ciclo dessas cultivares. Em se tratando de radiação solar na área de estudo verifica-se que as maiores variações ocorreram ao final do ciclo das cultivares, atingindo a máxima energia incidente aos cultivos de soja na ordem de $16 \mathrm{MJ} \mathrm{m}^{-2} \mathrm{dia}^{-1}$, registrada no $1^{\circ}$ decêndio de abril. Ao final do ciclo dessas cultivares analisadas, a radiação solar estava com valores em torno de $14 \mathrm{MJ} \mathrm{m}^{-2} \mathrm{dia}^{-1}$. Durante o ciclo das cultivares, nota-se que em Santarém o volume de água precipitado é superior, entre $60 \%$ a $65 \%$, em relação a Belterra. Até o início da floração, as chuvas em Santarém apresentaram valores entre $80 \%$ a $97 \%$ a mais do que em Belterra. Observou-se que entre os fatores biofísicos a oferta pluvial é a variável que mais influência na $\mathrm{PH}_{\mathrm{verde}}$, pois a radiação solar praticamente ficou oscilando entre 14 e $16 \mathrm{MJ} \mathrm{m}^{-2} \mathrm{dia}^{-1}$, ao considerar os ciclos das cultivares analisadas. Devido ao ciclo mais precoce das cultivares $\mathrm{C}_{5} \mathrm{e}$ $\mathrm{C}_{8}$ é possível observar que no período entre o primeiro decêndio de janeiro até o primeiro decêndio de abril essas cultivares passaram por menores variações em termos de radiação solar incidente, ao comparar com as demais cultivares analisadas. 


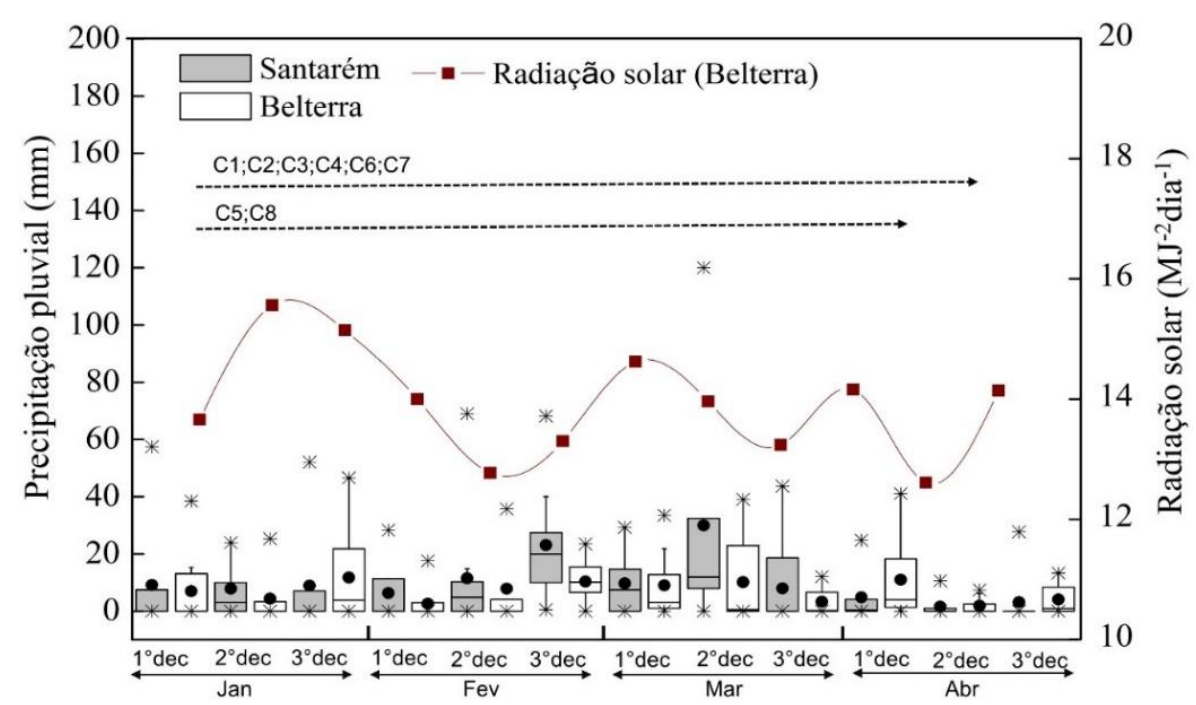

Figura 2. Variabilidade decendial média da precipitação pluvial e radiação solar, no período de 2009 a 2014 em Santarém e Belterra, Amazônia.

$\mathrm{Na}$ Tabela 2 observa-se que nos anos/safras analisados, a cultivar $\mathrm{C}_{8}$ foi a que apresentou a maior $\mathrm{PH}_{\text {verde }}$ em relação às demais, tendo o maior valor no ano safra 2009/2010 com $1.591 \mathrm{~m}^{3} \mathrm{ha}^{-1}$. Essa cultivar completa o ciclo em 96 dias com rendimento médio de 1,9 $\mathrm{tha}^{-1}$, indicando que houve baixa eficiência no uso da água da região. A cultivar $\mathrm{C}_{1}$ que completou seu ciclo com 107 dias, teve o menor valor de pegada hídrica verde $\left(885 \mathrm{~m}^{3} \mathrm{ha}^{-1}\right)$, no ano safra $2011 / 2012$, pois expressou rendimento de $2,7 \mathrm{t} \mathrm{ha}^{-1}$, porém estatisticamente teve semelhante desempenho das cultivares $\mathrm{C}_{2}$ e $\mathrm{C}_{3}$ no uso eficiente de água, conforme Figura 3 (A).

Tabela 2. Pegada hídrica verde das cultivares de soja (Glycine max) em safras agrícolas 2009/2010 a 2013/2014, no polo de grãos Santarém/Belterra.

\begin{tabular}{lccccc}
\hline \multirow{2}{*}{ Cultivares de soja } & \multicolumn{5}{c}{ Pegada Hídrica Verde $\left(\mathbf{m}^{\mathbf{3}} \mathbf{t}^{\mathbf{1}}\right)$} \\
\cline { 2 - 6 } & $\mathbf{2 0 0 9 / 2 0 1 0}$ & $\mathbf{2 0 1 0 / 2 0 1 1}$ & $\mathbf{2 0 1 1 / 2 0 1 2}$ & $\mathbf{2 0 1 2 / 2 0 1 3}$ & $\mathbf{2 0 1 3 / 2 0 1 4}$ \\
\hline C $_{1}$ (BRS 278RR) & 1103 & 986 & 885 & 1011 & 1007 \\
C $_{2}$ (BRS 325RR) & 1094 & 974 & 872 & 998 & 988 \\
C $_{3}$ (BRS 333RR & 1135 & 1012 & 908 & 1038 & 1031 \\
C4 $_{4}$ (P98Y70) & 1153 & 1027 & 920 & 1052 & 1042 \\
C $_{5}$ (BRS 279RR) & 1215 & 1074 & 957 & 1098 & 1075 \\
C $_{6}$ (BRS 8990RR) & 1338 & 1191 & 1067 & 1220 & 1208 \\
C $_{7}$ (BRS 271RR) & 1501 & 1338 & 1201 & 1372 & 1363 \\
C $_{8}$ (M8766RR) & 1591 & 1407 & 1253 & 1439 & 1408 \\
\hline
\end{tabular}

Os resultados também evidenciam que a dinâmica temporal da $\mathrm{PH}_{\text {total }}$ por cultivar durante os anos/safra 2009/2010 a 2013/2014 aumentaram gradativamente, principalmente ao contabilizar-se a pegada de cultivares como: $\mathrm{C}_{6}, \mathrm{C}_{7}$ e $\mathrm{C}_{8}$, possivelmente atribuídas à redução dos estoques de água no solo no período de maior necessidade hídrica que é a floração, o que compromete a produtividade da soja (Martorano et al., 2009). A cultivar $\mathrm{C}_{8}$ apresentou a maior $\mathrm{PH}_{\text {total }}$ que contabilizou $7.906 \mathrm{~m}^{3} \mathrm{t}^{-1}$, indicando sua baixa eficiência na conversão de uso da oferta hídrica da atmosfera para produzir grãos nesses anos/safras avaliados. Por outro lado, no ano/safra 2011/2012 essa mesma cultivar reduziu sua $\mathrm{PH}_{\text {total }}$ para $1.415 \mathrm{~m}^{3} \mathrm{t}^{-1}$, explicado pela sua baixa eficiência em expressar rendimento de grãos. Vale destacar que a pegada hídrica contabiliza os processos evapotranspiratórios decorrente das interações no sistema solo-plantaatmosfera em cada ano/safra.

Observou-se efeito significativo em nível de 5\% de probabilidade em relação a $\mathrm{PH}_{\text {total }}$ com

\section{IPABH}

Rev. Ambient. Água vol. 13 n. 5, e2051 - Taubaté 2018 
maiores valores para as cultivares $\mathrm{C}_{8}, \mathrm{C}_{7}, \mathrm{C}_{6}$, respectivamente. Ressalta-se que as menores pegadas hídricas foram contabilizadas nas cultivares $\mathrm{C}_{1}, \mathrm{C}_{2}$ e $\mathrm{C}_{3}$ (Figura 3A). Portanto, em termos de indicador de baixa pegada hídrica as cultivares BRS 278 RR; BRS 325 RR e BRS 333 RR foram as mais expressivas no polo de grãos no oeste do Pará

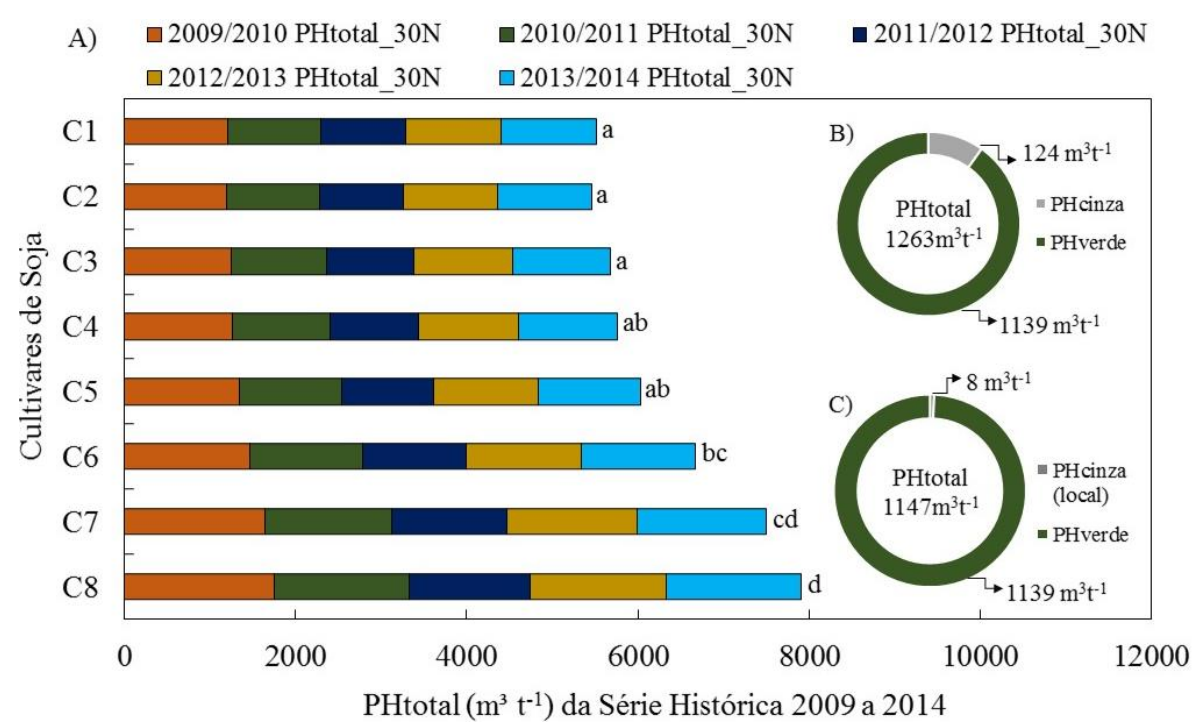

Figura 3. Pegada Hídrica total por cultivares de soja estimada no período de 2009 a 2014 considerando $30 \mathrm{~kg} \mathrm{ha}^{-1}$ de adubo nitrogenado (A). Pegada hídrica média considerando $30 \mathrm{~kg} \mathrm{ha}^{-1}(\mathrm{~B})$. Pegada hídrica média considerando adubação local de no máximo $2 \mathrm{~kg} \mathrm{ha}^{-1}(\mathrm{C})$.

A cultivar $\mathrm{C}_{1}$ obteve $\mathrm{PH}_{\text {total }}\left(5.520 \mathrm{~m}^{3} \mathrm{t}^{-1}\right)$ inferior às demais cultivares, atingindo-se no ano/safra 2011/2012 o valor de $991 \mathrm{~m}^{3} \mathrm{t}^{-1}$. Ao comparar com os rendimentos encontrados por Borges et al. (2012) de 2,7 tha ${ }^{-1}$ com 107 dias de ciclo médio, as estimativas de $\mathrm{PH}_{\text {total }}$ indicam que essa cultivar apresenta alta eficiência no uso de águas pluviais na região.

Ao comparar a $\mathrm{PH}_{\text {total }}$ média obtida no polo de grãos Santarém/Belterra com os resultados da literatura, observou-se que os valores obtidos neste trabalho foram inferiores aos valores de outras áreas produtivas no globo terrestre. Comparando com polos de grãos no Brasil, como por exemplo no Paraná, no município de Maringá (Bleninger e Kotsuka, 2015) a pegada hídrica da soja foi de $2.210 \mathrm{~m}^{3} \mathrm{t}^{-1}$, valor cerca de $43 \%$ superior aos valores obtidos no polo Santarém/Belterra. Vale destacar, mesmo que os cultivos de soja tenham sido irrigados em Maringá, os valores elevados de $\mathrm{PH}_{\text {cinza }}\left(420 \mathrm{~m}^{3} \mathrm{t}^{-1}\right)$, contribuíram para evidenciar que houve redução na eficiência do uso de água nos cultivos de soja. $\mathrm{Na}$ China, a $\mathrm{PH}_{\text {total }}$ da soja foi de $1.816 \mathrm{~m}^{3} \mathrm{t}^{-1}$ (Huang et al., 2012), diferente dos valores encontrados por Costa et al. (2016), também no Pará, mas no polo de grãos Paragominas, com valores da ordem de $1.327 \mathrm{~m}^{3} \mathrm{t}^{-1}$, os quais foram inferiores aos valores médios globais para a soja $\left(2.144 \mathrm{~m}^{3} \mathrm{t}^{-1}\right)$, apresentados por Mekonnen e Hoekstra (2010).

Vale ressaltar que em Santarém/Belterra os valores médios de pegada hídrica foram cerca de 30\% inferiores aos resultados na China, 5\% menores que as estimativas de Costa et al. (2016) para a soja em Paragominas e, $41 \%$ abaixo dos valores de pegada hídrica média global.

Assim, em relação aos valores disponíveis na literatura em outras regiões produtoras de grãos, as estimativas para o polo Santarém/Belterra apresentam a menor $\mathrm{PH}_{\text {cinza }}$, devido as baixas taxas de adubação nitrogenada na região, onde $2 \mathrm{~kg} \mathrm{ha}^{-1}$ indica que esses são os valores máximos quanto ao uso de $\mathrm{N}$ na adubação de cobertura pelos sojicultores da região. $\mathrm{A} \mathrm{PH}_{\text {cinza }}$ mais elevada contabilizou em média $8 \mathrm{~m}^{3} \mathrm{t}^{-1}$ para a soja, pois essa adubação é considerada desnecessária, pois considera-se o uso de inoculantes no processo de semeadura. Por outro lado, 
existem sistemas de produção de soja que demandam alta tecnologia, inclusive com uso elevado de $\mathrm{N}$, os quais podem atingir $300 \mathrm{~kg} \mathrm{ha}^{-1}$ (Lamond e Wesley, 2001). Também, estudos apontam que a adubação com $\mathrm{N}$ pode ser adotada em casos de baixa eficiência na fixação biológica da planta e reduzida fertilidade do solo (Petter et al., 2012).

\section{CONCLUSÕES}

- A dinâmica temporal da pegada hídrica do polo de grãos Santarém/Belterra aponta que as cultivares com alto potencial produtivo são eficientes em uso da oferta pluvial na região, reduzindo assim a pegada hídrica da soja na região;

- O baixo teor de nitrogênio utilizado na adubação da soja no oeste do Pará reduz a Pegada Hídrica Cinza em relação a outras áreas cultivadas no Brasil e no Mundo sendo um forte indicador de eficiência no uso consuntivo de água pela sojicultura na região;

- A manutenção das taxas evapotranspiratórias que refletem em rendimento de grãos nos anos/safras avaliados reforçam o potencial de uso da Pegada Hídrica Verde como indicador de eficiência hídrica pela soja produzida no oeste do Estado do Pará, na Amazônia.

\section{REFERÊNCIAS}

ALLEN, R. G.; PEREIRA, L. S.; RAES, D.; SMITH, M. Crop evapotranspiration: Guidelines for computing crop water requirements. Rome: FAO, 1998. (FAO irrigation and Drainage Paper, 56).

BLENINGER, T.; KOTSUKA, L. K. Conceitos de água virtual e pegada hídrica: estudo de caso da soja e óleo de soja no Brasil. Revista Recursos Hídricos, v. 36 p. 15-24, 2015. http://dx.doi.org/10.5894/rh36n1-2

BORGES, M. S.; EL-HUSNY, J. C.; CARVALHO, E. A. Comportamento de cultivares e linhagens de soja transgênica em Belterra, Pará. In: SEMINÁRIO DE INICIAÇÃO CIENTÍFICA DA EMBRAPA, 16., 2012, Belém, PA. Anais... Belém: Embrapa Amazônia Oriental, 2012.

COSTA, D. C.; MARTORANO, L. G.; MARQUES, M. C.; EL-HUSNY, J. C.; NACIF, A. Pegada hídrica como indicador de sustentabilidade em polo de grãos na Amazônia. $\begin{array}{llllll}\text { Enciclopédia } & \text { Biosfera, } & \text { v. } & 13, & \text { p. } & 920-929,\end{array}$ http://dx.doi.org/10.18677/Enciclopedia_Biosfera_2016_079

ERCIN, A. E.; HOEKSTRA A. Y. Water footprint scenarios for 2050: A global analysis. $\begin{array}{llllll}\text { Environment International, } & \text { v. } & 64, & \text { p. } & 71-82,\end{array}$ http://dx.doi.org/10.1016/j.envint.2013.11.019

FOOD AND AGRICULTURE ORGANIZATION - FAO. CROPWAT 8.0 Model. Rome, 2010. Disponível em: www.fao.org/nr/water/infores_databases_cropwat.html/ Acesso em: 20 set. 2017.

FARIAS, J. R. B.; NEPOMUCENO, A. L.; NEUMAIER, N. Ecofisiologia da Soja. Londrina: Embrapa soja, 2007. 9p. (Comunicado técnico, 75).

INSTITUTO BRASILEIRO DE GEOGRAFIA E ESTATÍSTICA - IBGE. Síntese de indicadores sociais: uma análise das condições de vida da população brasileira. 2016. Disponível em: https://www.ibge.gov.br/. Acesso em: 12 de março 2018.

HOEKSTRA, A. Y.; CHAPAGAIN, A. K.; ALDAYA, M. M.; MEKONNEN, M. M. The Water Footprint Assessment Manual. London: Earthscan; 2011. 
HUANG, J.; ZHANG, H.; TONG, W.; CHEN, F. The impact of local crops consumption on the water resources in Beijing. Journal of Cleaner Prodution, v. 21, n. 1, p. 45-50, 2012. http://dx.doi.org/10.1016/j.jclepro.2011.09.014

LAMASTRA, L.; SUCIO, N. A.; NOVELLI, E.; TREVISAN, M. A new approach to assessing the water footprint of wine: An Italian case study. Science of the Total Environmental, v. 84, 2014. http://dx.doi.org/10.1016/j.scitotenv.2014.05.063

LAMOND, R. E.; WESLEY, T. L. In Season Fertilization for High Yeld Soybean Production. Better Crops With Plant Food, v. 85, n. 2, p. 6-7, 2001.

MARTORANO, L. G.; NECHET, D.; PEREIRA, L. C. Tipologia climática do Estado do Pará: adaptação do método de Köppen. Boletim de Geografia Teorética, v. 23, p. 45-46, 1993.

MARTORANO, L. G.; BERGAMASCHI, H.; DALMAGO, G. A.; FARIA, R. T. de; MIELNICZUK, J.; COMIRAN, F. Indicadores da condição hídrica do solo com soja em plantio direto e preparo convencional. Revista Brasileira de Engenharia Agrícola e Ambiental, v. 13, p. 397-405, 2009.

MEKONNEN, M. M.; HOEKSTRA, A. Y. A global and high-resolution assessment of the green, blue and grey water footprint of wheat. Hydrology and Earth System Sciences, v. 14, n. 7, p. 1259-1276, 2010. http://dx.doi.org/10.5194/hess-14-1259-2010

MILLENNIUM ECOSYSTEM ASSESSMENT - MEA. Ecosystems and human well-being: a framework for assessment. Washington, DC: Island Press, 2003. 245 p.

PARÁ. Secretaria de Estado da Agricultura - SAGRI. Website. 2016. Disponível em: http://www.sedap.pa.gov.br. Acesso em: 10 out. 2017.

PETTER, F. A.; PACHECO, L. P.; ALCÂNTARA NETO, F.; SANTOS, G. G. Respostas de cultivares de soja à adubação nitrogenada tardia em solos de cerrado. Revista Caatinga, v. 25, n. 1, p. 67-72, 2012.

UNESCO (UNITED NATIONS). Educational, scientific and cultural organization: Relatório Mundial das Nações Unidas sobre Desenvolvimento dos Recursos Hídricos. WWAP. 2016. 12p.

UNITED NATIONS EDUCATIONAL, SCIENTIFIC AND CULTURAL ORGANIZATION - UNESCO. Department of Economic and Social Affairs/Population Division. World Population Prospects: The 2015 Revision, Key Findings and Advance Tables. Working Paper No. ESA/P/WP.241. Paris, 2015a. 66p.

UNITED NATIONS EDUCATIONAL, SCIENTIFIC AND CULTURAL ORGANIZATION - UNESCO. Relatório mundial das Nações Unidas sobre o desenvolvimento dos recursos hídricos. Água para um mundo sustentável- Sumário Executivo. WWDR. Paris, 2015b. 08 p.

VARELA-ORTEGA, C.; KOK, K.; BLANCO-GUTIÉRREZ, I.; HELFGOTT, A.; TOLEDO, M.; CLAVIJO, F. et al. A handbook for the participatory process in ROBIN: Development of methods for local stakeholder meetings. Grenoble: Robin Consortium, 2013. 154 p. http://dx.doi.org/10.13140/RG.2.2.26558.69447

WU, B.; ZENG, W.; CHEN, H.; ZHAO, Y. Grey water footprint combined with ecological network analysis for assessing regional water quality metabolism. Journal of Cleaner Production, v. 112, p. 3138-3151, 2016. http://dx.doi.org/10.1016/j.jclepro.2015.11.009 